Louisiana State University

LSU Digital Commons

1997

\title{
Penitent Brothellers: Grace, Sexuality, and Genre in Thomas Middleton's City Comedies.
}

Herbert Jack Heller

Louisiana State University and Agricultural \& Mechanical College

Follow this and additional works at: https://digitalcommons.Isu.edu/gradschool_disstheses

\section{Recommended Citation}

Heller, Herbert Jack, "Penitent Brothellers: Grace, Sexuality, and Genre in Thomas Middleton's City Comedies." (1997). LSU Historical Dissertations and Theses. 6492.

https://digitalcommons.Isu.edu/gradschool_disstheses/6492

This Dissertation is brought to you for free and open access by the Graduate School at LSU Digital Commons. It has been accepted for inclusion in LSU Historical Dissertations and Theses by an authorized administrator of LSU Digital Commons. For more information, please contact gradetd@lsu.edu. 


\section{INFORMATION TO USERS}

This manuscript has been reproduced from the microfilm master. UMI films the text directly from the original or copy submitted. Thus, some thesis and dissertation copies are in typewriter face, while others may be from any type of computer printer.

The quality of this reproduction is dependent upon the quality of the copy submitted. Broken or indistinct print, colored or poor quality illustrations and photographs, print bleedthrough, substandard margins, and improper alignment can adversely affect reproduction.

In the unlikely event that the author did not send UMI a complete manuscript and there are missing pages, these will be noted. Also, if unauthorized copyright material had to be removed, a note will indicate the deletion.

Oversize materials (e.g., maps, drawings, charts) are reproduced by sectioning the original, beginning at the upper left-hand comer and continuing from left to right in equal sections with small overlaps. Each original is also photographed in one exposure and is included in reduced form at the back of the book.

Photographs included in the original manuscript have been reproduced xerographically in this copy. Higher quality $6 " \times 9$ "black and white photographic prints are available for any photographs or illustrations appearing in this copy for an additional charge. Contact UMI directly to order.

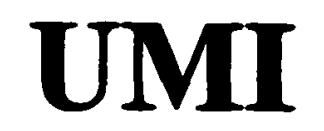

A Bell \& Howell Information Company 300 North Zeeb Roed, Ann Arbor MI 48106-1346 USA

$313 / 761-4700 \quad 800 / 521-0600$ 
PENITENT BROTHELLERS:

GRACE, SEXUALITY, AND GENRE

IN THOMAS MIDDLETON'S CITY COMEDIES

\author{
A Dissertation \\ Submitted to the Graduate Faculty of the \\ Louisiana State University and \\ Agricultural and Mechanical College \\ in partial fulfillment of the \\ requirements for the degree of \\ Doctor of Philosophy \\ in \\ The Department of English \\ by \\ Herbert Jack Heller \\ B. A., Bryan College, 1985 \\ M. A., Louisiana State University, 1989 \\ June 1997
}


UMI Number: 9808749

\section{Copyright 1997 by \\ Heller, Herbert Jack}

All rights reserved.

UMI Mieroform 9808749

Copyright 1997, by UMI Company. All rights reserved.

This microform edition is protected against unauthorized copying under Title 17, United States Code.

\section{UMI \\ 300 North Zeeb Road \\ Ann Arbor, MI 48103}


CCopyright 1997

Herbert Jack Heller

All rights reserved 


\section{Acknowledgements}

Members of my dissertation committee include Dr. Gale Carrithers (Chair), Dr. Anna Nardo, Dr. Kevin Cope, and Dr. Carolyn Jones. I have enjoyed their encouragement, patience, and constructive suggestions through the long process of writing this study. I am most grateful for their guidance throughout. Extra thanks go to Dr. Carrithers for introducing me to Thomas Middleton's works.

Several scholars involved in Middleton studies have responded to my inquiries-Dr. Gary Taylor, Dr. Peter Saccio, Dr. Mario DiGangi, and Dr. Paul Mulholland. Their help is appreciated. Thanks also to the SCCCL and SCMLA for giving me opportunities to present my research.

A project like this is undertaken with the friendship, help, blessings, examples, and prayers of many friends. Deeply felt thanks go to the Wells family-John Henry, Shelley, and Amanda; the Smiths-Alvin, Kathy, Rachel, and Hannah; Karen Law; Keary Freeman; Dr. Janice Stein; the Kinchens; the McCollisters; Skip Sharrer; David McPherson; the Louivieres; Laurie Matherne; Holly Rodick; Dr. Peter Yaukey; Brandt Hardy; Jeff DeNio; David Stonestreet; Greg and Ruth; Melinda and Billy; Nathanael and Fanny.

Without moving back home, I would have never completed this work. My biggest thanks, therefore, go to my Mother and Father. With Love. Gloria in excelsis Deo! 


\section{Preface}

"Penitent Brothel" is the name of Thomas Middleton's best-known penitent, a character in A Mad World, My Masters. Middleton uses the term "brotheller" to describe Theodorus Witgood in A Trick to Catch the Old One (II. i. 3). Hence my coinage of "penitent brothellers" to refer to the penitents and converts in Middleton's comedies, the characters upon which this dissertation focuses.

All of the texts which receive major consideration in this study have long been accepted as Middleton's works. However, I also refer to texts for which his authorship has only been accepted recently. Therefore, I am taking as his canon the list of works to be included in the upcoming collected works of Middleton, to be published soon by Oxford University Press. The play I refer to as The Second Maiden's Tragedy will be included as The Lady's Tragedy; the title I use comes from the edition I cite. In a few instances, I will note similarities between texts long accepted as Middleton's and those for which his authorship has only recently been proposed; such observations, of course, strengthen the authorship arguments. However, I will not argue for the authorship of any text; the reader may refer to the editions cited and the discussions which will be in the Oxford edition.

The editing principles of the texts I use vary in degrees of modernization of spelling and punctualtion. I have decided to keep the 
spelling of each edition, even though this may present slight difficulties for the reader. I also use several texts for which there is no modern edition. For these only, I have modernized the usage of $u, v, i$, j, and s; I have also expanded the spelling of words for which the early modern abbreviation is no longer common: "cõuersant" becomes "conversant"; "yt" becomes "that" (unless "it" is intended). Any other changes are marked as such with brackets.

Most Bible quotations come from three different sources: the $1611 \mathrm{King}$ James translation, Middleton's pamphlet The Two Gates of Salvation, and the Geneva Bible. The quotes given without a specific translation reference come from the King James version. 


\section{Table of Contents}

Acknowledgements ................. iii

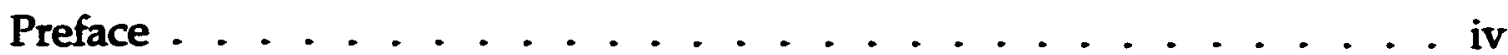

Abstract .............................. vii

One: Thomas Middleton, Calvinist Dramatist . . . . . . . . . 1

I. Notes . . . . . . . . . . . . . . . . 33

Two: Grace, Repentance, and Genre: A Mad World, My Masters,

The Widow, and A Chaste Maid in Cheapside . . . . . . . . . 38

I. "Is it a tragedy plot, or a comedy plot, good mother?":

Repentance and Genre in Middleton Criticism . . . . . . . . . 38

II. From Brothel to Once-Ill: Penitent's Paradigmatic Conversion in A Mad World, My Masters . . . . . . . . . . . . . . . . 59

III. "That he might read his actions i'th' event?": The Patterns of Repentance . . . . . . . . . . . . . . 94

IV. Sir Walter Whorehound's Anti-Tragic Repentance . . . . . 105

V. Notes . . . . . . . . . . . . . . . . . . . . 124

Three: Marrying the Whore: The Hosea Paradigm

in A Trick to Catch the Old One and Other Plays . . . . . . . . 136

I. Notes . . . . . . . . . . . . . . . . . . 158

Four: Sodomy, Salvation, and the Stage: Satires, Michaelmas Term,

and The Roaring Girl . . . . . . . . . . . . . . . . . 161

I. Unspoken Things in the Historical, Literary, and Critical Contexts 161

II. "Time was I loved Pyander well": The Wide Indication of Sodomy in Middleton's Satires . . . . . . . . . . . . . 180

III. Undoing Sodomy: Richard Easy's Redemption in Michaelmas Term . . . . . . . . . . . . . . . . . . 193

IV. Redeeming the Sodomite Stage in The Roaring Girl . . . . . . 235

V. Notes . . . . . . . . . . . . . . . . 284

Five: Conclusion . . . . . . . . . . . . . . . . 297

I. Notes . . . . . . . . . . . . . . . . 302

Works Cited . . . . . . . . . . . . . 303

Vita ................................. 315 


\begin{abstract}
This dissertation focuses on the repentance and conversion scenes in Thomas Middleton's city comedies. It asserts the importance of recognizing Middleton's Calvinism for reading the plays' religious elements.

Chapter one critiques both the common omission of the religious language from criticism of the comedies and the emphasis on the tragedies and Puritan politics in recent studies. The pamphlet The Two Gates of Salvation is used to theorize Middleton's method of investigating Calvinist theology in the comedies.
\end{abstract}

Chapter two examines the conversion of Penitent Brothel in A Mad World, My Masters, and the repentances of Francisco in The Widow and Sir Walter Whorehound in A Chaste Maid in Cheapside. These responses to grace help to define genre in Middleton's canon; comedies show significant repentances, tragedies show rejections of grace. Variants in the first quarto show that Penitent's name changes from Brothel to Once-Ill when he converts. Comparisons of his conversion are made to Francisco's repentance to show Middleton's pattern of repentance. Sir Walter's repentance is then shown to prevent a tragic ending to $A$ Chaste Maid. Chapter three observes the frequent marriages of prostitutes in the comedies. Focusing on A Trick to Catch the Old One, it proposes a prostitute's marriage is a paradigm for grace, paralleled in the life of the 
prophet Hosea. The chapter also suggests that the Courtesan is a moral example to Witgood.

Chapter four reads the satires Microcynicon and Father Hubbard's Tales, and the plays Michaelmas Term and The Roaring Girl to show how Middleton applies grace to homosexuality. Middleton opposes sodomy, but he engages the subject of homosexuality without marginalizing the sodomite from his own social millieu. According to opponents of the theatre, Middleton himself could have been regarded as guilty of sodomy by association with the theatre. Thus, he treats the problem of homosexuality as if he were implicated in it, using a sodomitical narrative voice in Microcynicon, using a feminized persona to redeem the sodomite in Michaelmas Term, and redeeming the sodomite stage in The Roaring Girl. 


\section{One: \\ Thomas Middleton, Calvinist Dramatist}

In 1983, "Accompaninge the players": Essays Celebrating Thomas Middleton, 1580-1980 was published in the AMS Studies in the Renaissance series to observe the four hundredth anniversary of the Jacobean dramatist's birth. Kenneth Friedenreich introduces the volume with "How to Read Middleton," an essay using the little-known romantic comedy The Widow (1616) to suggest the typical elements of Middleton's language and plotting. For Friedenreich, the play's ordinariness recommends its examination for that which can be generalized about Middleton's dramatic works1:

The play incorporates earlier plot and character devices less, it appears, because Middleton lacked fresh invention than because he enjoys reworking his devices into new situations with different implications.... Though perhaps less acid than his better-known comedies, The Widow reveals Middleton's hallmarks as a dramatist nonetheless. It illustrates what novice readers might expect of him. [4]

Those hallmarks of Middleton's language, Friedenreich suggests, are its plainness, its bawdiness, and its frequent legalisms (8), qualities evident to anyone having more than a cursory familiarity with Middleton's work. The value of these qualities may differ among the readers; for example, Middleton's plainness, praised by Friedenreich, may be what makes Middleton "but a base fellow" in Ben Jonson's conversations with William Drummond (line 158). But one other common feature of Middleton's language is omitted from Friedenreich's list: it is often explicitly theological. 
In Act III, scene ii of The Widow, the gallant Francisco is sneaking up to Justice Brandino's house by night, hoping to keep an already delayed rendezvous with Phillipa, the justice's wife. However, Francisco sees another figure in the woods by the house, and believes it to be a spirit:

Life, what should that be? a prodigious thing Stands just as I should enter, in that shape too, Which alwaies appears terrible.

What ere it be, it is made strong against me

By my ill purpose. For 'tis mans own sin

That puts on armor upon all his evils,

And gives them strength to strike him: were it less

Then what it is, my guilt would make it serve;

A wicked mans own shadow has distracted him:

Were this a business now to save an honour,

As 'tis to spoil one, I would pass this then

Stuck all hels horrors i'thee: now I dare not. [89-101]

Francisco further reasons with himself:

And what do's fond man venture all these ills for,

That may so sweetly rest in honest peace?

For that which being obtained, is as he was

To his own sence, but remov'd neerer still

To death eternall: What delight has man

Now at this present, for his pleasant sin

Of yesterdaies committing?

[107-113]

He concludes his contemplation on the figure:

Whose check so ere thou are ...

I thank thee, peace requite thee;

Light and the lighter Mistris both farewell.

He keeps his promise best that breaks with hell. [120-123]

As it turns out, the figure in the woods is not a spirit, but a young

woman disguised as a man, fleeing, she hopes, to the first safe haven away from a gang of thieves she encountered in the forest. Friedenreich is correct to note that Middleton reworks his dramatic ideas. This encounter should 
remind any Middleton reader of Penitent Brothel's encounter with the succubus in A Mad World, My Masters. Both Penitent and Francisco are having adulterous affairs, both believe themselves to have seen a spirit, and both are frightened enough of their sinfulness to repent.

In Act V, Francisco meets the young lady, Martia, again, never recognizing her as the figure in the woods, but instantly lovestruck. They are married before the scene is over, and they offer this advice to Phillipa:

[Martia:] Heav'n will not let you sin, and you'ld be carefull. Francisco: Winat means it sends to help you, think and mend, You'r as miuch bound as we, to praise that frend.

"Heav'n" here serves as a metonymy, of course, for God. Heaven's operation ("What means it sends to help you") conforms to the standard Calvinist definition of grace as a divine gift. In the Institutes, Calvin writes, "It follows, as we lately observed, that those virtues, or rather images of virtues, of whatever kind, are divine gifts, since there is nothing in any degree praiseworthy which proceeds not from [God]" (II: 75).

Middleton's Calvinism might appear at odds with the bawdiness of his plays, and ultimately with his very participation in the theatrical community in London. However, the Puritan opposition to the theater, leading to the closing of the professional stages in 1642, does not encompass all post-1530s Protestant thinking about the stage (i. e. after the rise of Calvinism), not even for all Puritans. Calvin himself has some things to say about theatre, including comedy, which suggests a divided opinion rather than the usual dismissal of theatre associated with Calvinism. 
Calvin is a strong proponent of the idea that the physical world is the theatre of God's glory, a Christian adaptation of the theatrum mundi. Citing the Pauline paradox that God's foolishness is superior to human wisdom, he defines God's wisdom as encompassing "this magnificent theatre of heaven and earth replenished with numberless wonders, the wise contemplation of which should have enabled us to know God" (Institutes I: 93). In letters to Philip Melanchthon, Calvin refers to himself as an actor-"the position in His theater to which God has elevated me" (cited in Bouwsma 178)-his church as a theatre.

Yet, because of their infulness, people commonly miss the instructive benefits of the magnificent theatre of the world. After citing Psalm 107, about the "sudden and unexpected succour" God gives to the miserable, Calvin regrets,

As the greater part of mankind, enslaved by error, walk blindfold in this glorious theatre, [the Psalmist] exclaims that it is a rare and singular wisdom to meditate carefully on these works of God, which many, who seem most sharp-sighted in other respects, behold without profit. [Institutes I: 57]

The Christian, however, is instructed to attend to God's work in this theatre: "Being placed in this most beautiful theatre, let us not decline to take a pious delight in the clear and manifest works of God" (I: 156). ${ }^{2}$

Calvin's enthusiasm for the theatrum mundi extended to one actual stage production. In 1546, he rebuked a Genevan minister for denouncing a performance of the acts of the apostles, and the drama went on with his 
approval (T. Parker 100-101). Yet Calvin also denounced the "lying fictions" of the theater (Bouwsma 179), and again in 1546, he concurred with the Genevan Council in suppressing a drama of Hercules (Parker 100).

One of Calvin's conflicts with the secular stage is its ethos, including the issue of where the characters place responsibility for their actions. Citing passages from Roman comedy, Calvin asserts that his doctrine of divine providence does not permit a person to say his culpability is due really to God's activity. Those who have learned the modesty of acquiescing to God's supreme authority, he claims,

will neither murmur against God for adversity in time past, nor charge him with the blame of their own wickedness, as Homer's Agamemnon does: "Blame not me, but Zeus and fate." On the other hand, they will not, like the youth in Plautus, destroy themselves in despair, as if hurried away by the Fates. "Unstable is the condition of affairs; instead of doing as they list, men only fulfill their fate: I will hie me to a rock, and there end my fortune with my life." Nor will they, after the example of another, use the name of God as a cloak for their crimes. For in another comedy Lyconides thus expresses himself: "God was the impeller: I believe the gods wished it. Did they not wish it, it would not be done, I know." [Institutes I: 185-186]

No extant Plautine or Terentian play has a passage corresponding to the youth hurried away by the Fates, ${ }^{3}$ but from Plautus' Aulularia, Calvin accurately presents a combination of lines 737 and 741 , in which Lyconides attempts to justify his illicit sexual relations with Euclio the senex's daughter. What attracts Calvin's attention is not so much what Lyconides has done, but what he says about it, "[using] the name of God as a cloak for [his] crimes." However, implicit in Calvin's critique is an acknowledgement 
of the affective limits of theatrical mimesis. If God is not the impeller of Lyconides' crimes, does the stage representation of Lyconides itself impell crimes? But those who submit to God's authority will not "after the example of another [stage character] use the name of God as a cloak for their crimes." In other words, they will not be led into sin by witnessing the activities of a stage sinner.

Calvin, in fact, parallels the usually ineffectual work of the glorious theatrum mundi with the frequent failure of the theatre to affect the behavior of its audience. A funeral, for example, should cause us "to philosophise admirably on the vanity of life." But, unfortunately, "At the best, our philosophy is momentary. It vanishes as soon as we turn our back, and leaves not the vestige of remembrance behind: in short, it passes away, just like the applause of a theatre at some pleasant spectacle" (II: 26-27). Responsibility for the audience's reaction to the theatre, whether the theatre of God's glory or the Globe, rests with the audience themselves, even though, because of human folly, they will usually react inappropriately.

Theatrical mimesis disturbs Calvin most when the mimetic act itself seems in direct violation of an edict of God. A violation would include the "lying fiction" of the Hercules drama Calvin helped to ban. In reference to the transvestism of the European stages and the strictures of Deuteronomy 22: 5 , he also comments,

In these maskings \& mummings, when men put them-selves into womens apparel, and women put them-selves into mens as ye know: what comes of it? Although no euil ensued thereof, yet the verie thing 
it self displeseth God.... But besides this, we are sure the suffring hereof is the opening of a gap to all whoredome. At a word, such disguisings are but inticements of baudry, as experience prooueth. on Deuteronomy, qtd. in P. White 233-234]

[ Sermons

A practical effect of applying this interpretation would be to close the theatres entirely, and as Paul Whitfield White notes, this "would be constantly quoted thereafter by the stage's opponents" (170). However, the opponents would seem to have missed Calvin's mention of the "pleasant spectacle" at the theatre, suggestive of a benign pleasure.

Friendlier to the stage were some of Calvin's Continental followers and the Marian exiles. Theodore Beza, Calvin's successor as head of the Genevan Church, was himself an occasional playwright; contrary to Calvin's own ruling, Beza deemed acceptable the transvestism of boys' performing female roles (White 171). He also exerted his efforts to convince others of this opinion: "Neither did he only affirm this, but brought such Divines as opposed themselves against it, to be of his opinion, with the whole assent and consent of all the Ecclesiasticall Synod in Geneva" (Richard Braithwaite, The English Gentleman [1630], qtd. in White 234).4

In England, antitheatrical prejudice gained more force from the arguments of Stephen Gosson and Philip Stubbes after the advent of commercial theatre companies in the late 1570s. English theatre from the late 1530 s to 1580 , however, was dominated by the works of playwrights committed to the Reformation.5 Among these playwrights was John Foxe, whose Acts and Monuments (commonly known as The Book of Martyrs) 
was placed in every church during Elizabeth's reign (Gasper, Dragon 3). One of the church authorities whom Foxe opposed was Stephen Gardiner, the Catholic Bishop of Winchester. Foxe comments briefly about the stage in his explanation of his dispute with Winchester. In a letter reprinted by Foxe, the Bishop of Winchester writes to the Lord Protector,

Certain printers, players, and preachers, make a wonderment, as though we know not yet how to be justified, nor what sacraments we should have. And if the agreement in religion made in the time of our late sovereign lord be of no force in their judgment, what establishment could any new agreement have? And every uncertainty is noisome to any realm. [Foxe, Acts VI: 31]

Foxe responds to Winchester,

He thwarteth, also, and wrangleth much against players, printers, preachers. And no marvel why: for he seeth these three things, to be set up of God, as a triple bulwark against the triple crown of the pope, to bring him down; as, God be praised, they have done meetly well already. [VI: 57]

Among his own contemporaries, for doing meetly well Foxe could have been thinking of John Bale for King Johan, Thomas Kirchmayer for Pammachius, and his own Christus Triumphans, which he calls a "comoedia apocalyptica." Later anti-papal plays include Thomas Dekker's The Whore of Babylon (also a comoedia apocalyptica [Gasper 62]) and Middleton's Second Maiden's Tragedy and A Game at Chess.

Foxe's Christus Triumphans allegorically dramatizes the early militant Protestant interpretation of the Revelation of John, with the Whore of Babylon as the Catholic Church and the seven-headed hydra as Rome. The play's early reception seems based more on its theology than its theatrical 
merits. Written originally in Latin, Christus Triumphans was first printed in Basel in 1556. A French translation followed in 1561, a performance at Trinity College, Cambridge in 1562, and another edition from Nuremberg in 1590 (Foxe, Comedies 34-35). In 1672, the play was re-edited as a school text for Sidney Sussex College, Cambridge, the alma mater of Oliver Cromwell. This editor introduced the work with a poetic address to schoolmasters proposing Foxe's value over the Roman comedians:

In one stroke, one strike you may learn the wit of Plautus and with it that of Christ. Why hesitate? What do you fear, since divine scripture has preeminence over profane scripts?... Foxe cuts off the foreskins of the lewd stage and baptizes the muses with the water of heaven, free from the filth of sin, water which cleanses the mind even as it purifies the lips. [Foxe, Comedies 36-37]

We may well wonder if the history of English antitheatricalism would have changed if Foxe's other play, Titus et Gesippus, had been printed in his time. Foxe presented the play to a prospective employer for a tutoring post, and he probably did not intend it for performance. But far from circumcizing the lewd stage (or castrating it), Foxe's comedy is completely in imitation of New Comedy. Titus and Gesippus are friends who look alike and are mistaken for one another. They end up marrying each other's brides by the play's end. The slaves all have names from Terence: Phormio, Syrus, and Dromo. Simo, the senex and father of one of the brides, is taken from Plautus. Though the play is hardly bawdy, the only ostensibly Christian element in the play is its last two lines: "Farewell, and rejoice in Christ Jesus, that he may take you into his feast" (Comedies 197). 
Even though Foxe is commonly characterized as a Puritan, the placement of Acts and Monuments in every church gave him an official authority which the separatist Puritans would never obtain. The apocalyptic imagery of Christus Triumphans is most imaginatively offered in The Faerie Queene, and more successfully dramatized in Dekker's The Whore of Babylon (1605). The "Puritan" of Henry VIII's and Mary's reigns is later received as the leading proponent of a historical theory which gives England a central place in the preservation of the One True Church. Foxe also exalts individual resistance, especially to religious tyranny, making him a potential time bomb against the future of the Anglican Church, but Foxe supported Queen Elizabeth and was recompensed in kind.

Although opposition to the theatre rose after 1580 with the advent of the commercial theatres, it would be a mistake to suppose that opposition characterizes a majority Protestant attitude towards the stage. The complexities of English antitheatricalism are usefully examined in Jonas Barish's The Anti-Theatrical Prejudice and Margot Heinemann's Puritanism and Theatre; the key point to note here is that most opposition to the theatre, rather than being in toto, was directed instead to specific practices, such as Sunday performances, transvestism, and bawdy acting. Indeed, one of the early tract-writers against the abuses of the stage, Stephen Gosson, was himself a playwright. In partial response to Gosson, Sir Philip Sidney wrote his Defence of Poesy. Although his religious beliefs are not prominent in his major writings, Sidney had strong Protestant sympathies, 
dying for the cause during the Dutch war against Spain. Antitheatrical writers, especially William Prynne who conducted the broadest attack, may characterize their views as the true upholding of the Christian religion. But the partisans for the theatre during Elizabeth's and James' reigns cannot be generally characterized as non-Christians. The theatre debate was conducted by disputants sharing religious presuppositions, so much so that Gosson presumed to dedicate his School of Abuse to Sidney before knowing Sidney's own views.

After Foxe's death, Acts and Monuments itself became source material for a number of dramatists. The anonymous play The Troublesome Raigne of King John (1591), Samuel Rowley's When You See Me, You Know Me (on the reign of Henry VIII, 1604), Thomas Dekker's and John Webster's Sir Thomas Wyatt (c. 1602), Dekker's The Whore of Babylon (c. 1605), and Thomas Heywood's If You Know Not Me, You Know Nobody; Or, The Troubles of Queen Elizabeth (1605)—all of these plays take positions on historical events corresponding to Foxe's positions (Gasper, "Reformation Plays" 190-216). Other dramatists who put forward explicitly Protestant treatments of history, politics, Biblical narrative, morals and ethics, and theology include Christopher Marlowe in The Massacre at Paris (1593), George Peele in David and Bethsabe (1594), Thomas Lodge and Robert Greene in A Looking Glass for London and England (c. 1592), William Rowley in his collaborations with Middleton, and Heywood, Dekker, and Webster in other plays. Of course, in individual cases, these plays may not 
represent their authors' private or final opinions, especially for Marlowe and Thomas Lodge who later converted to Catholicism. However, the general point remains-that there is a tradition of Protestant drama extending into the Jacobean era. More critics now acknowledge this tradition, but it has not yet shaped the presuppositions which critics generally bring to the Renaissance plays they examine.

This is not to suggest that Protestantism is an easy fix for interpretive difficulties. Nor does this suggest that those dramatists whose religious perspectives we can determine have written plays that are usually about religion. Rather, this is to suggest that for Renaissance dramatists, religion serves them as Debora Shuger claims it serves their culture:

Religion during this period supplies the primary language of analysis. It is the cultural matrix for explorations of virtually every topic: kingship, selfhood, rationality, language, marriage, ethics, and so forth. Such subjects are, again, not masked by religious discourse but articulated in it; they are considered in relation to God and the human soul. That is what it means to say that the English Renaissance was a religious culture, not simply a culture whose members generally were religious. [6]

Most dramatists, including Middleton, were not writing primarily as evangelists. True, Middleton often stages the conversions or repentances of his characters. But the Jacobean audience could generally be expected to know all about conversion and repentance. Hence, for example, the White Queen's Pawn's conversion by theological recovery in A Game at Chess is a point scored against the black chess pieces, Spain and the Catholic Church. The contemporary accounts of the play show the play met with notorious 
applause, Spanish consternation, royal disapproval, and censorship, but never do those accounts mention a change in the audience's personal religious perspectives.

Friedenreich concludes his article on The Widow with the provocative suggestion that Middleton constructs his best plays around terms which, taken in their variety of meanings, set the priorities for the interpretation of the plays. His examples of such terms include "fools" in Michaelmas Term and "warrants" in The Widow. Friedenreich writes,

Middleton's careful semantic "field" creates his "moral field"-a construct superior to the more generalized "moral vision" that critics claim Middleton depicts. Each play establishes its own system of values whose relativity-not universality-Middleton dramatizes.... We must, then, consider Middleton's moral "field" as something less than rigid, universal, or proscribed. The particular follies or vices of his creations remind us that our own enterprises are motivated by desires for recognition, acceptance, love, security, and wealth; that our relative success or failure owes as much to wit as to circumstance as to opportunity as to serendipity. [12-13]

The Calvinist resonance of the passages cited from The Widow already raises problems with the capriciousness implied by attributing success or failure to wit, circumstance, or serendipity. However, Friedenreich's use of "moral field" corresponds well with Middleton's typological theology, especially his description of the spiritual life in The Two Gates of Salvation. This pamphlet presents Biblical texts from the Old and New Testaments on facing pages. These facing pages are headlined "The first Gate" and "The second Gate" in the first edition (1609), "The Mariage of the old/and new Testament" in 1620, and "The Prophets" and "The Evangelists" in 1627.6 
In his dedication in 1609 to an unnamed "worthy deserver of all true honours," Middleton writes,

This booke is as it were a Map of a Large kingdome, wherein you may see so much drawne forth, as was promised by the King of Heaven and Earth should be bestowed upon his onely Begotten Sonne. The Citty of the soule is builded Above, And through these two Gates must shee passe, if shee Travell to Salvation. The one Gate was opened more then $\mathbf{5 0 0 0}$ yeares agoe, (even presently after the world was made) for to Adam himselfe was a Mesiah promised. At that Gate, Prophets stood waiting, and telling newes of his comming. But to us the otherGate is opened, and wee are assured that ourShepheard is come, Christ hath bin a dweller with us upon earth. In whose Birth, Life, Wordes, Deedes, Passion, Death, Resurrection, and Ascension is fulfilled whatsoever (of him) was fore-told. I am a meere stranger to your eye (though not to the good fame that lives of you familiarly conversant.) But Sithence the Voiage of every professed Christian, lies by one Way (And that Way is set downe heere, by the principles of Spirituall Naoigation. ) Accept of my poore knowledge therin, I beseech you, which offers itselfe, not as a Guide unto your Jorney (you no doubt having skil enough of your owne.) But as a perfect Circle of my love, filled with many wishes, that after you have gone through this first Gate of a Momentary life, you may enter in at that second, which leadeth to all eternity and happinesse. [A2r and v]

The Two Gates of Salvation is wholly orthodox in its Calvinist

theology; this is evident on the basis of two marginal notes to the New Testament verses in "the second gate." The first of these verses refers to the last judgment, Matthew 25: 32: "Before Christ shall be gathered all nations, and hee shall separate them one from another, as a shepheard divideth his sheepe from the Goates, and hee shall set the sheepe on his right hand, and the Goates on the left." To this Middleton adds the annotation, "The Judgement-day, the Elect, and the Reprobate" (Sig. F1). Later in the text, Middleton cites Romans 9: 20-21: "But O man, who art thou which pleadest against God? Shall the thing formed say to him that formed it, Why hast 
thou made me thus? Hath not the Potter power of the clay, to make of the same lump one vessel to honour, and another to dishonour" (Sig. G4). The annotation is, "Predestination. This similitude aptly agreeth in the first creation of Mankinde." Middleton's glosses are consistent with Calvin's uses of these verses (Institutes II, 228-229, 272), but as Paul Mulholland notes, these glosses have no antecedents in the three Bible translations Middleton uses in this pamphlet ("Two Gates" 33).

Yet for all the Calvinist thinking evident from these passages, Middleton's language suggests that the theology does not proscribe the means of religious experience (except, of course, that any religiously true experience originates from God, the "Potter"). Like John Bunyan in Pilgrim's Progress seventy years later (1678), Middleton uses a metaphor of journey for the spiritual life: "the Voiage of every professed Christian lies by one Way" (A2v). But that voyage for Middleton is not down one pathway. In Part Two of Pilgrim's Progress, Christiana travels what is essentially the same path as her husband Christian did before her; she and her children leave the City of Destruction, pass by the Slough of Despond, and go on to the Interpreter's house, up the Hill Difficulty, down through the Valley of Humiliation, past Doubting Castle, and on to the Celestial City. For Middleton, on the other hand, the journey is through a "Large kingdome," and it is travelled "by the principles of Spirituall Navigation."

Middleton's metaphors shift in their references and are primarily spatial; both of these qualities lead away from the inherent rigidity of 
concepts for the spiritual journey in Pilgrim's Progress. For example, maps of large kingdoms in the Jacobean era are notable for their incompleteness; a reader may "see so much drawne forth" without seeing all there is or thought to be. With the "Citty of the soule ... builded Above," the kingdom is multi-dimensional and perhaps, therefore, not altogether on the map.7 The two gates through which the soul must pass to salvation are the Old and New Testament (texts), the Prophets and the Evangelists (authors), and also "this first Gate of a Momentary life" and "that second which leadeth to all eternity and happinesse."

"Spirituall navigation" introduces a further widening of the range of the Christian voyage. According to the OED, "navigation" is not known to have been used during Middleton's time to describe travelling by land. Indeed, only later was the term used to describe travel inland on rivers or canals (earliest citation: 1727). If the journey was chartable on the map of a kingdom, now it is confined only by the destination and the instruments of navigation used to reach it. A reader may easily infer the expanses of the seas as the planes of travel.

Middleton dramatizes his trope of spiritual navigation in his elaborate civic pageant The Triumphs of Truth (1613), presented on the occasion of the selection of a new mayor of London, and portraying Truth's successful contention with Error for his loyalty. The pageant travels to St. Paul's churchyard8: 
No sooner can your eyes take leave of these [previous scenes], but they may suddenly espy a strange ship making toward, and that which may raise greater astonishment, it having neither sailor nor pilot, only upon a white silk streamer these two words set in letters of gold, Viritate gubernor, - I am steered by Truth. [247]

This ship carries a king of the Moors, his queen, and attendants. The king, explicitly a black African, expresses his gratitude for being "brought to the true Christian faith" by "the religious conversation/ Of English merchants, factors, travellers" (248). Then he describes further the manner by which the ship has come to London:

If any wonder at the safe arrive Of this small vessel, which all weathers drive According to their rages, where appears Nor mariner nor pilot, armed 'gainst fears, Know this came hither from man's guidance free, Only by Truth steer'd, as our souls must be: And see where one of her fair temples stands! [249]

Truth would seem to have its own method of travel, but not necessarily its own course for arriving at its final destination: All weathers drive Truth's ship according to their rages. The voyage by which the Truth comes to the Moors is presumably not the route Truth has taken to the English travellers themselves. Of course, there is a parochial, patriotic inevitability in all of Middleton's Truth-travellers converging upon St. Paul's ("one of [Truth's] fair temples"). That point aside, however, spiritual navigation guided by Truth is certain only of its destination, salvation, not of the routes, nor of the lives, of the individuals who will arrive there.9

In The Two Gates, the navigational instruments or maps or gates are not offered as "a Guide unto your Jorney ... But as a perfect Circle of my 
love." Mixed though they may be, Middleton's metaphors here continually suggest an expanse of possible Christian experiences, delimited only by the providence of God and the substance of the two gates, the Scriptures. The circle of Middleton's love parallels the range of God's providence, an echo of God's grace.

Friedenreich's use of "moral field," instead of the more common critical term "moral vision," suggests the range or space of experiences in The Two Gates of Salvation, but that range is classified imprecisely as moral. This classification, of course, implies a position on the long and now exhausted debate on whether Middleton's works are immoral, amoral, or moral. Modern critics of Middleton, myself included, bring to his works sensibilities shaped by the ethics of Kant, Mill, and Sartre. It is possible for us to speak of the morality of a text as a broader range of concerns, and as a separate issue from the religious concerns in the text. Some of the confusion about Middleton's morality comes from not seeing these moral concerns as subsumed to Middleton's religious preoccupations. But no major religion (except perhaps Confucianism) foregrounds its ethical values over and above the dogmatics that usually serve as the premises for those values. Christian theologians generally acknowledge, in varying degrees, that the ethical standards of the faith are humanly impossible to maintain, and furthermore, that some standards are no longer applicable to those freed from them: "For the law of the Spirit of life in Christ Jesus hath made me free from the law of sin and death" (Romans 8: 2). This concept of being 
freed from some standards is what Middleton dramatizes in the tragicomediesA Fair Quarrel and The Old Law.

By substituting "Calvinist" for Friedenreich's "moral" field, we can still acknowledge the range of experience in the field, take an essential position on the question of Middleton's morality, and more accurately describe his preoccupations. The "relativity of each play's system of values" (12) can be better seen as the relativity of the circumstances in each play by which Middleton investigates his own Calvinist beliefs. Thus, for example, Catholicism in Middleton's plays ranges in representation from the Jesuit text that prompts Penitent Brothel's conversion (1606), to the allegorical denunciation of Catholic hegemony over spiritual and political matters in The Second Maiden's Tragedy (c. 1611), to the Calvinist resonance of the Florentine Lord Cardinal's pronouncements in Women Beware Women (c. 1621), to the anti-Jesuit satire of $A$ Game at Chess (1624). This range does not suggest any ambivalence in Middleton's essential anti-Catholic biases which he shared in common with Jacobean London culture; rather, it suggests that the work of grace is not limited by circumstances such as the accident of the authorship of Penitent's text or the accident of setting in the Italy of Women Beware Women.

The construction and printing history of The Two Gates of Salvation also reflect the Calvinist field of Middleton's thought. Middleton uses three Bibles for his scriptures-the authorized Bishop's Bible, the Geneva Bible preferred by Protestant dissenters, and the revision of the Geneva Bible by 
Laurence Tomson (Mulholland 28). In a few instances, Middleton departs from all three translations, usually to clarify the match he is identifying between Old and New Testament verses. One example of this is when he changes Matthew 27: 9, 10 to say "Zacharias" instead of "Jeremias" to match Matthew's text with Zechariah 11: 12, 13 (C4r). 10

The first printing of The Two Gates in 1609 comes between the earlier plays Michaelmas Term and The Revenger's Tragedy, and the later plays The Second Maiden's Tragedy, The Roaring Girl, and No Wit, No Help Like a Woman's. Mulholland notes that for the 1609 edition, "The ideological bias ... would not appear to be strong" (33). It is more evident in 1620 when Middleton dedicates the work, now titled The Marriage of the Old and New Testament, to two London Puritans, Richard Fishborne and John Browne. 11 This 1620 edition is roughly contemporary to Hengist, King of Kent; More Dissemblers Besides Women; and Women Beware Women. Finally, because the 1627 edition was printed the year Middleton died, without his authorship credited, its authority is uncertain; however, it should be noted that three years after $A$ Game at Chess, the work is now titled God's Parliament House. The Two Gates not only reveals some of the workings of Middleton's Calvinist (and moral) field, but the text itself serves as a guage of his religious and political commitments. The field variesfrom two gates to a parliament-as Middleton becomes increasingly political, culminating in $A$ Game at Chess. 
This study of Middleton's city comedies attempts to correct the omission of his religious language and perspectives from previous studies, such as we have examined in Friedenreich's article and which we will see from other critics. There is another strain of Middleton criticism, however, which acknowledges his Christianity. Critical attention to his Christianity has grown since 1980 with the publication of Margot Heinemann's Puritanism and Theatre: Thomas Middleton and Opposition Drama under the Early Stuarts. Yet, while Middleton's Calvinism should now be considered factually established, studies as late as 1994 observing the point still regard it as a novel insight. 12

Middleton's Christian perspective had been noticed long before 1980 . In 1915, in the introduction to his neglected edition of Middleton plays, Martin Sampson calls Middleton "a sympathetic interpreter of repentance as well as the desires that bring repentance in their train" (29). Referring to the tragedies in 1962, Irving Ribner claims, "Middleton's plays are conditioned by a Calvinistic bias which leaves little room for the redemption of sinners" (125). J. A. Bryant Jr. in 1976 also finds "in Beatrice-Joanna an example of what professing Calvinists still call reprobation" (590), and he suggests parallels between Middleton's Protestantism and modern frankness about sexual motivations. The most detailed analysis of Middleton's Christianity before 1980 is Charles Hallett's Middleton's Cynics, published in 1975. With his focus on Middleton's opposition to cynicism, Hallet concludes the 
comedies are failures. Nevertheless, he offers a strong argument (examined in chapter two) for the integrity of Penitent Brothel's conversion which, though neglected, has not been superseded by subsequent studies. 13

The issue Heinemann raises and which has since dominated the critical attention to Middleton's religion is his relationship to Puritanism. Heinemann focuses on Puritanism as a political opposition movement, describing Middleton's position as an "open Parliamentary Puritan stand," which "may account for the general absence of contemporary eulogy by actors or fellow dramatists" (171). Much of the emphasis for this and other politically focused readings rests upon texts from Hengist, King of Kent (1618) and later. Indeed, Middleton's last play, A Game at Chess (1624), is the centerpiece of the argument for his supposed Puritanism. From that play, "Puritanism" has been read chronologically backwards into earlier texts, so that Puritan dissent has been detected in the late major tragedies and the mid-career tragicomedies, starting with The Witch (1615). There are a few readings of religious perspectives in earlier plays, but thus far the political analysis of Middleton's religion goes no earlier than 1613, the year A Chaste Maid in Cheapside satirized Puritans.

A Game at Chess was immediately notorious for its opposition to the proposed marriage between Prince Charles and the Infanta Maria of Spain. The Spanish ambassador to England, the Count of Gondomar, is mocked as the Black Knight, with gross attention given to his fistula. The ideological 
basis for Middleton's attack is his opposition to Catholicism, so he also broadly satirizes the Jesuit brotherhood.

Contemporary texts note the popularity the play had with a wide, religious audience. In a 1624 letter, John Chamberlain states it was "frequented by all sorts of people old and younge, rich and poore, masters and servants, papists and puritans" (Steen 46). If the "Papist" audience enjoyed the play, they probably preferred its nationalistic, anti-Spanish jabs. Lisa Hopkins has shown that British Catholics were as likely to be antiSpanish as their Protestant compatriots (chapters one and two).

If Hopkins' explanation covers the reasons why a Catholic would have attended the play, what would have attracted a "Puritan" audience, perhaps even to the extent that certain individuals would set aside their usual opposition to the theatre? A problematic answer is given in William Hemminge's mock "Elegy on Randolph's Finger," in which Jacobean dramatists are sending off the poet Thomas Randolph's amputated finger to Elysium. Having no money, the dramatists are refused passage on Charon's boat, so they approach a group of Puritans who are carrying "Orphants goodes new Gulld at Amsterdame" (178):

to thes, though thay seemed poor, the Poettes went and to theyr worships Pamphelettes did present of pretty begging lines; but they will none but what weare made by hopkinges or Tom stone. They Quakte at Iohnson as by hym thay pase because of Trebulation Holsome and Annanias, But Middleton thay seemed much to Adore fors learned Excercise gaynst Gundomore. 
Tribulation Wholesome and Annanias are the satirical Puritans of Jonson's The Alchemist, an English pastor and a deacon of Amsterdam.

But if Hemminge's Puritans prefer Middleton's work to Jonson's for ideological reasons, Middleton himself is not what they expect (187-192):

To whom thay thus pray, Can you Edifye our understandinges In this misterye? wth Teares the storye hee begane whilest thay prickt upp thayr eares and did begin to pray. the sad tale ended, Nosing out 'prophane,' straight for the finger wisht the man [Randolph] weare slayne.

On the basis of $A$ Game at Chess, the Puritans suppose Middleton is able to edify their understandings in the mystery of the dramatists' journey through Hades (187-188). He tells his story while they pray (189-190), but "nosing out 'prophane," they "straight for the finger wisht the man weare slayne" (191-192). If anti-theatrical Puritans were likely to equate bawdiness with profanity (a still common confusion), then the profanity that undermines these Puritans' favor could be seen as characteristic of the bawdiness in Middleton's plays. He may have been much adored for his exercise against Gondomor, but in Hemminge's text, the Puritans remain opponents to the theatre. Their spokesman claims, "The Pope has Juglinge trickes and can use slightes to Converte Players Into Jesuittes" (205-206). Martin Sampson, who labels Middleton "a sympathetic interpreter of repentance," also anticipates the argument for his Puritanism and its problems: "If he had been a Victorian, his outspoken licence would have been prurient; if in his own day he had written with Victorian reticence, he 
would have been a precisian" (30). If precisianism were wholly synonymous with Puritanism, we could easily dismiss the argument for Middleton's Puritanism. But "Puritanism" is a broad term which encompasses contradictory perspectives in its various applications. James I claims "the name of Puritan doth properly belong only to that vile sect amongst the Anabaptists, called the Family of Love" (Heinemann 78). Heinemann writes of "Parliamentary Puritanism" and "separatists" (171); Gary Taylor, of "moderate Puritanism" ("Forms of Opposition" 289); Jonas Barish, of "Puritan anti-theatricalism" (chapters four and six).

Heinemann usefully situates Middleton's drama historically by examining his relationship to his patrons and London politics. Yet she must also admit,

Middleton never uses the word 'Puritan' in a favourable sense, even though from 1613 onwards he had a number of City patrons who were what we should call active Puritans. For him, a Puritan always means a sectary, and what he is satirising is not the broad main stream of reforming opposition, or the opinions of the 'middling sort' in the early years of the seventeenth century, but rather 'ultra-holiness' and hypocrisy. [77]

Heinemann elsewhere says that Middleton uses "Puritan" to refer to separationists and not to reformers of the church from within (76). He ends up in the Puritan camp by being among those who "wished either to purify the usage of the established Church from the taint of Popery, or to worship separately by forms so purified" (A. G. Dickens; qtd. in Heinemann 77).

As significant as Heinemann's work has been in bringing renewed attention to Middleton's religion, it has had little effect upon the study of his 
comedies. There are three problems with her work which more recent scholarship reveals: an over-simplified chronology, a narrow emphasis on politics (which has resulted in a lack of attention to the comedies), and an insufficient consideration of Middleton's satirical portrayal of Puritans.

The faulty chronology is more evident today than it would have been in 1980. Older studies of Middleton's canon divide his career chronologically into city comedies (up to 1613), tragicomedies (the mid1610s), and tragedies with $A$ Game at Chess (c. 1618-1624). But more recent studies of authorship, dates, and theatre records show at least six tragedies in his first decade of drama writing: The Chester Tragedy (lost); Caesar's Fall (a lost collaborative effort); The Revenger's Tragedy; A Yorkshire Tragedy; The Second Maiden's Tragedy; and, as Shakespeare's collaborator, Timon of Athens. Comedies after 1613 include The Widow, The Nice Valour, Anything for a Quiet Life (with Webster), and The Puritan Maid, the Modest Wife, and the Wanton Widow (lost).

Because the recent studies of Middleton's religion have focused on plays dated after 1613, there is an implicit notion in much of the criticism that his religion had little influence on his earlier, major comedies. That can be questioned by referring to G. B. Shand's article "The Elizabethan Aim of The Wisdom of Solomon Paraphrased." Shand reads this piece of juvenilia, published when Middleton was seventeen (1597), as "a statement of patriotic Elizabethan protestantism, Calvinistically tinged, and including much apparent compliment to Elizabeth herself" (75). With Middleton's 
Calvinist beliefs located at the very beginning of his writing career, efforts to pin down when his religious views surface in his writings should be regarded as pointless.

Heinemann's emphasis on politics as the arena of public policy disputes results in the barest consideration of plays like A Mad World, My Masters (two paragraphs and two sentences) and A Trick to Catch the Old One (four pages). However, Hengist, King of Kent, Middleton's only chronicle history play, merits a chapter because of parallels between the plot and current controversies involving the Duke of Buckingham. Both comedies have as much religious comment as Hengist; yet because they are not "political" in the same sense, they receive only scant attention. One does not have to subscribe to the popular critical maxim that "everything is political" in order to see that these comedies engage their current social issues from religious perspectives, if not necessarily public policy. John Stachniewski faults Heinemann's method: "In her enthusiasm to see Puritans as forming a coherent political opposition at this early date [1620] (highly dubious in itself), she cannibalises the plays for social documentation, [and] largely ignores their language and structure" (227-228). For Heinemann, labelling Middleton as a Puritan is more a political observation than a religious one.

The main problem with claiming that Middleton is a Puritan (which Heinemann acknowledges) is that he himself never mentions Puritans favorably. Satires of Puritans occur in several plays: The Puritan, or the 
Widow of Watling-Street (c. 1606); A Chaste Maid in Cheapside (1613); Hengist (c. 1618); The World Tossed at Tennis (a masque; 1619-1620); and The Puritan Maid (lost, c. 1620s). Having defining "Puritan" as a sectarian in Middleton's usage, Heinemann suggests that his tone towards them changes after 1613 when he first receives their patronage, presumably because he becomes one of them. But as the dates of these texts show, most of his satiric portrayals of Puritans occur after 1613 as well.

We do not have enough data to comment specifically on how Middeton's Puritan associates responded to his parodies. One very slight possibility is that his Puritan characters were not familiar to his patrons. Or Middleton's associates, including London's mayors and several merchants, would not have seen themselves as the lower class Puritans of the plays. It may even be that Middleton's criticism of ineffectual Puritanism was deemed appropriate by his patrons, or at least different from the broader critique of Puritans as a class in Jonson's plays. Finally, though the effort needed is beyond the scope of this study, the "Puritanism" of these patrons also needs to be re-evaluated.

The problem with Middleton's "Puritanism" is ultimately one of definition. He is a Puritan if the definition is a person who wants "to purify ... the established Church from the taint of Popery" (Heinemann 76-77). However, seventeenth century writers, including Middleton, liked to use "Puritan" as a pejorative, and its usefulness depended upon its vagueness. Julia Gasper offers an alternative term which has the benefit of clarity: 
militant Protestant. A militant Protestant is a person politically committed to the Reformation and whose theology, like John Foxe's, was apocalyptic (Dragon 2-3). Puritans can be militant Protestants, but militant Protestants are not necessarily Puritans. Gasper's term fits Middleton better than Puritan, and it can apply as well to Thomas Dekker, Edmund Spenser, Philip Sidney, John Webster, Thomas Heywood, and Middleton's patrons.

The one drawback with using "militant Protestant" is that, without Gasper's precision, it can quickly be distorted by inappropriate comparison to our current religious politics. Middleton is a militant Protestant writer in The Second Maiden's Tragedy and A Game at Chess, but he is more importantly a Protestant writer of all his texts. And the Protestantism evident in his texts is Calvinist. I prefer the use of "Calvinist" to either "Puritan" or "militant Protestant" because it refers to a theological commitment evident in the texts even when other political commitments are not prominent. As for Middleton's particular denominational commitment, my reading of $A$ Mad World, My Masters in chapter two suggests he remained in the Anglican fellowship. However, firm evidence is lacking and, in a sense, the issue is irrelevant to my study as long as we acknowledge his basic theological commitment to the Reformation.

The Two Gates of Salvation is an appropriate text for establishing a theoretical foundation for reading Middleton's canon. Like his Calvinism, it remains a constant text in his career, printed more often during his lifetime than any of his other works and with the majority of the text, his 
scripture citations, unchanged. But also like his dramatic works, it is reworked "into new situations with different implications" (Friedenreich 4), with new titles, new page headings, and new dedications. And even the constant center of the text, the scripture citations, incorporates both authority, the Bishop's Bible, and dissent, the Geneva Bible.

What distinguishes Middleton from his contemporaries is this variety located within his constant faith. In comparison to Shakespeare and Jonson, Middleton is notably explicit in commitment to a single theological system. In comparison to other Calvinist dramatists, such as Dekker, Webster, and Heywood, Middleton shows more interest in investigating dramatically the implications of ideas and the ranges of experiences accounted for in his theology. His canon has about the same number of extant plays as Heywood's and Dekker's, but his provoke more interest because, instead of posturing partisanly on his beliefs, he is more willing to ask and consider how his beliefs work. The terminology of travel and navigation in the dedication to The Two Gates epitomizes his investigations.

The focus of this study will be on the religious expression of Middleton's major city comedies, redressing both the dominant strain of criticism in which his religion is summarily dismissed, and the strain in which its expression is arbitrarily dated after 1613. The most common expression of religious sentiment in these comedies is the repentance or conversion of a sexual sinner, hence the connection of grace and sexuality in my title. Sexuality is inextricably linked with politics in current criticism, 
pithily expressed in the title of Susan Zimmerman's collection of criticism, Erotic Politics: Desire on the Renaissance Stage. My study emphasizes theology over politics, but theology is not politically irrelevant. We will see in chapter three, for example, that the presence of grace problematizes the masculinist presumption of labelling fallen women as whores without the admission of male complicity. Middleton's investigations of grace occurred historically in the contexts of Jacobean social, political, and religious controversies; these will be referred to throughout this study.

Middleton's plays do not represent societies whose ethos is especially religious. Rather, he represents grace at work among the con artists, prostitutes, duellers, investment speculators, homosexuals, and politicos of a secular, and typically profane, urban society. Middleton's profane, urban settings suit a Calvinist's belief in human depravity and the demonstration of grace upon the undeserving.

Chapter two begins with an examination of the problems of genre in Middleton's plays. In Thomas Middleton and the New Comedy Tradition, George Rowe claims that Middleton's dramatic vision is essentially anticomic. Middleton's comedies usually have some moment when a character receives grace; his tragedies usually have some moment when a lead character, such as Vindice, Beatrice-Joanna, and the Duke of Florence, declines an offer of grace. This study will look for the extent to which grace itself is a defining feature of genre in Middeton's canon. This chapter will also propose a pattern for the conversions or repentances of Middleton's 
sexual transgressors, reading Penitent Brothel's conversion as paradigmatic. The pattern will be tested by application to the conversion of Francisco in The Widow and a thorough consideration of the problematic repentance of Sir Walter Whorehound.

Chapter three investigates the relationships between the typological Old Testament book of Hosea, the portrayal of marriage as a mode of grace in The Book of Common Prayer, New Testament texts on the Church as the Bride of Christ and backsliders as adulterers, and the prostitutes who reform and marry in Middleton's plays, focusing on A Trick to Catch the Old One. As related in his book, Hosea marries the prostitute Gomer as he was commanded by God; the purpose of this marriage was to show both the unfaithfulness of Israel and the grace of God in remaining true to his people. Middleton refers to Hosea several times in The Two Gates. This chapter will consider Hosea as a paradigm and Middleton's prostitute characters as theatrical emblems for the workings of God's grace.

Chapter four uses readings of the early satires Microcynicon andFather Hubbard's Tales, and the plays Michaelmas Term and The Roaring Girl to show how Middleton applies his theology of grace to homosexuality. As a Calvinist, Middleton is opposed to sodomy, but his application of grace is more generous than is common for his time. Salvation is as available to his homosexual characters as it is to his adulterers, courtesans, and cheats. Furthermore, Middleton's engages the subject of homosexuality without marginalizing the sodomite from his own social millieu. According to the 
antitheatricalists, Middleton himself could have been regarded as guilty of sodomy by association with the theatre. Thus, while maintaining his moral opposition, Middleton treats the problem of homosexuality as if he were implicated in it, using a sodomitical narrative voice in Microcynicon, using a feminized persona to redeem the sodomite in Michaelmas Term, redeeming the sodomite stage in The Roaring Girl. This, my longest chapter, involves the most intricate argument, but its value comes from revealing Middleton's broadest application of grace, broader even than the many current political references to the Christian tradition would suggest. The chapter also reveals Middleton's commitment to his vocation as a dramatist, confronting antitheatricalism from his own Calvinist perspective.

These readings of Middleton's plays will be done with references to other social, political, and religious texts. In a sense, these texts anchor Middleton's examinations of grace into known situations and practical concerns rather than letting them drift into purely academic theology. The result of this study should be the confirmed existence of a supposed oxymoron-a Calvinist comedian, engaged in the issues of his time.

\section{Notes}

1I is not my purpose for the moment to dispute Friedenreich's assessment of the status of The Widow in Middleton's canon. However, the plot situations and characters seem removed, first, from the satiric examinations of contemporary London life evident even in other plays set in "Jacobean" Italy, and second, from the examination of grace and law evident in contemporary Middleton plays, A Fair Quarrel andThe Old Law. The critical focus on The Widow turns from originality to craftsmanship, but as a romantic comedy, it is less typical of Middleton's oeuvre than Friedenreich allows. And as Friedenreich himself claims, to say that the play is ordinary, 
as a Middleton work or in the genre of romantic comedy, is not to say that it is dull (4). The Widow was popular during the Restoration and was revived until the second quarter of the eighteenth century (Levine lviii-lx).

2The Christian adaptation of the idea of the world as theatre has its initial sources in I Corinthians 4: 9 and Hebrews 10:33, in which believers are the theatre of God's work to the world and to angels.

Calvin's perspectives on theatre are more complicated than there is room to consider here; an authoritative chapter on the subject appears in William Bouwsma's John Calvin: A Sixteenth-Century Portrait.

3John T. McNeill, editor of the 1960 Westminster edition of the Institutes, cites Pistoclerus of Plautus' Bacchides as the suicidal youth. Pistoclerus' slave-tutor Lydus has the more suicidal lines (149-152), but they do not correspond well to Calvin's apparent paraphrase.

4Richard Braithwaite, by the way, held that moderate play-going was permissable, but he argued against excessive attendence and condemned plays that jested aginst "religion, matters of state, and great persons" (Heinemann 35).

5This is part of the major argument of Paul Whitfield White's Theatre and Reformation. He discusses at length the use of the theatre to expose the perceived failings of Catholicism and concludes that the stage greatly influenced the formation of Tudor Protestant culture. Also useful for understanding this period of drama is John Hazard Smith's "Introduction" to Two Latin Comedies by John Foxe the Martyrologist.

6The family of Middleton's wife Mary Marbeck was distinguished both in Protestant religious circles and the arts. Her paternal grandfather, John Marbeck, was a popular church organist. He also compiled the first English concordance to the Bible, which probably aided Middleton's writing of The Two Gates of Salvation.

7We should note the Augustinian nature of Middleton's "City of the Soul." Augustine is cited five times in this pamphlet, and Middleton's use of the navigation metaphor has parallels in Augustine's De Beata Vita. In his introduction to The City of God, John O'Meara summarizes De Beata Vita:

The major image here ... is the "land of desire." There are two "ways" to this land, both across a sea. One is the way of reason, which, possible only for the few, brings men to the harbour of philosophy, which is the harbour of the land of desire. The other way is the way of Providence 
which uses the storms of adversity to bring men, resist and wander in ignorance and folly as they may, to the same harbour. [xvi]

Though Calvin is closer in time to Middleton, the reading of Augustine through the lens of the Reformation may have had more direct influence on Middleton's writing.

8Because of a lack of lineation in the text and because of the mix of prose and poetry, references to The Triumphs of Truth will be given by the page number of Bullen's edition.

${ }^{9} \mathrm{~A}$ different use of the navigation and voyage metaphors appears in A Trick to Catch the Old One. Witgood thinks about the loss of his estate to his uncle Lucre, whose conscience he compares to an ocean:

But where's Long-acre? in my uncle's conscience, which is three years' voyage about; he that sets out upon his conscience never finds the way home again-he is either swallowed in the quicksands of law-quillets, or splits upon the piles of a praemunire [a sheriff's writ]. [I. i. 7-11]

Lucre's conscience, devoid of spiritual truth and moral foundation, shipwrecks those who would hope to find him dependable.

Little notice has been paid to the parallels in Middleton's own life in the situations he dramatizes. His stepfather Thomas Harvey invested in and journeyed to the New World in a disastrous expedition organized by Sir Walter Raleigh and led by Sir Richard Grenville. Having lost everything, Harvey tried to gain possession of the estate left by Middleton's deceased father. The effort involved a series of lawsuits between family members that lasted at least until Middleton was twenty-one and already working in the theatres (Barker 1-8). Middleton's use of navigation metaphors to describe a person's spiritual life is a natural result of some events in his life. The time is right for a renewed critical attention to the biographical information we have on Middleton.

10Hebrew scholars generally note that when the Greek Septuagint Old Testament was in use, Jeremiah's name was used generically to refer to the prophets.

11These two men were later involved in smuggling Dutch-printed newsletters into England, possibly including those opposed to Prince Charles' proposed marriage to the Spanish Infanta Maria (Heinemann 157). Middleton dramatizes his own opposition in A Game at Chess.

${ }^{12}$ Two reasons are evident for the continuing treatment of Middleton's Calvinism as a novel insight. The first is that the conventional grouping of 
Calvinists, Puritans, and antitheatricalists in literary histories maintains a strong hold on popular assumptions (and high school literary surveys). The second is that critics who otherwise disavow the verities of dated literary histories still omit religion from their own study.

The grouping of Calvinists, Puritans, and theatre opponents is often so broadly formed as to be of no practical use. Puritans were generally Calvinist, but so were many High Church men, including George Abbott, Archbishop of Canterbury from 1611 (Gasper Dragon, 6). And antitheatricalists came from every religious perspective, including, as noted earlier, the Catholic Bishop of Winchester. Yet to speak of a writer as a Calvinist comedian is counter-intuitive, as if a judge from The Crucible were suddenly to ask if you had heard the one about the farmer's daughter.

The omission of religion in more recent studies may stem from the supposed antagonism between Christianity and the critical perspective used. For example, The Roaring Girl has risen in critical acceptance because of the work of feminist and gay theorists, but for reasons having little to do with Sir Alexander Wengrave's repentance in Act $V$ (discussed in chapter four). The resulting studies, however, are certain to be incomplete. John Stachniewski cautions,

If Saussure ... [has] taught us anything of scarcely disputable importance, it is that meaning does not inhere in particular words but is generated by the differentiation of synchronic terms. This being so, the neglect of aspects of the language of a text disfigures the meanings even of those aspects which are examined.... Whatever our view of this or that religio-cultural formation-and we ought in the end, in justice to ourselves, to come clean about our own moral evaluation-we should attempt a criticism which gives attention to the religious language of that culture commensurate with its density in the text. [227]

13David Holmes approaches a consideration of Middleton's Christianity in his 1970 study The Art of Thomas Middleton. Holmes claims:

For Middleton, reality inhered in the operation of a universal justice which directs man towards worthy behaviour and away from sin; and we have seen indications of his personal faith in man's ability to respond to that direction, and of his determination to applaud worthy motives. [39]

The problem with this is its vagueness; "universal justice" has a name in Middleton's works. The same vagueness appears when Holmes describes the force that guides Francisco and Philippa to proper behavior in The Widow: "manifestations of the operation of a supernatural agency that attempts to guide men away from iniquity" (143). In The Widow itself, Martia speaks of heaven, not of supernatural agency (V. i. 507). Holmes' is the only study of Middleton where his religion is suggested, but made to 
look like a different one by its generalities. The main value of Holmes' study is as a survey of Middleton's career, but even as such, it can be misleading because of its emphasis on works which are no longer credited to Middleton's authorship. 


\section{Two:}

\section{Grace, Repentance, and Genre: A Mad World, My Masters, The Widow, and A Chaste Maid in Cheapside}

I. "Is it a tragedy plot, or a comedy plot, good mother?": Repentance and Genre in Middleton Criticism

Most of Middleton's plays have a repentance or a conversion scene. ${ }^{1}$ These are related but distinct activities in Protestant theology. Repentance is the more general activity of confession and rejection of one's sin. It may be done either for a specific sin, such as adultery or theft, or for one's state of sinfulness. Conversion includes repentance, but it also indicates a change from unbelief to belief in the gospel of Jesus Christ, and thus from reprobation to salvation. Both activities involve a recognition of the folly of one's ways, but conversion creates the Christian. Repentance is a part of conversion because one must believe that he or she is reprobate in order to be saved from the state of reprobation. However, because Christians continue to sin, repentance remains an ongoing responsibility, "that ordinary repentance which the corruption of nature obliges us to cultivate during the whole course of our lives" (Calvin, Institutes I: 525).

A repentance scene is relatively easy to identify in Renaissance drama: it occurs when a character renounces his or her sin, usually while expressing a religious conviction. A conversion, however, may not be so easily identifiable. Prohibitions against using the name of Jesus Christ on the stage and other restrictions can obscure the distinction between repentance and conversion. Thus, for example, when in The Roaring Girl Sir Alexander 
Wengrave relents and permits his son Sebastian to marry Mary Fitzallard, his change of mind is called a repentance-"Glad you're so penitent for your former sin, sir" (V. ii. 113). Yet Sir Alexander reacts as if he has obtained salvation, the result of conversion-"How short my sleep of sorrow seems now to me/ To this eternity of boundless comforts" (V. ii. 175-176). In drama, the distinction between repentance and conversion will not be as fine as their theological definitions may suggest. It may be useful to consider a conversion as a repentance with an additional emphasis on the penitent's obtaining salvation or eternal life.

Converts and penitents in Middleton's comedies would include Penitent Brothel and Mistress Harebrain in A Mad World, My Masters; Theodorus Witgood and the Courtesan in A Trick to Catch the Old One; Richard Easy in Michaelmas Term; Sir Walter Whorehound in A Chaste Maid in Cheapside; Philip in No Wit, No Help Like a Woman's; Captain Ager in A Fair Quarrel; Francisco in The Widow; White Queen's Pawn in A Game at Chess; and, as just noted, Sir Alexander Wengrave. Some characters in Middleton's tragedies also repent-Husband in $A$ Yorkshire Tragedy, Gratiana in The Revenger's Tragedy, Helvetius in The Second Maiden's Tragedy, Lapyrus in The Bloody Banquet. Except for the murderous Husband of $A$ Yorkshire Tragedy, however, the leading villains do not convert or repent in Middleton's tragedies.

This is not because they have no opportunity to do so. In The Revenger's Tragedy, Gratiana repents during a confrontation with her son 
Vindice (IV. iv.); yet Vindice does not recognize a need for his own repentance. In The Second Maiden's Tragedy, the Tyrant opposes himself to the Protestant faith, which is represented emblematically by Govianus and Helvetius (a name derived from the Latin for "Switzerland"). In Women Beware Women, the Lord Cardinal pleads for the repentance of both his brother, the Duke of Florence, and Bianca, the Duke's illegitimate bride (IV. i. and iii.). In The Changeling, Beatrice-Joanna embraces her own spiritual deflowering when she embraces De Flores. De Flores insists upon his moral equality with Beatrice-Joanna, who has engaged him to commit murder: "Look but into your conscience, read me there,/ 'Tis a true book, you'll find me there your equal" (III. iv. 132-133).

Repentance and conversion in Calvinist theology are the human responses to God's conviction of sin and the offer of salvation. These activities of God are works of grace, which I defined generally in chapter one as the good will of God towards people and the kindness and love he bestows on them, especially for their salvation. In The Two Gates of Salvation, Middleton quotes Romans 9: 25-26: "I will call them my people, which were not my people, and her, beloved, which was not beloved, and it shall be in the place where it was said unto them, ye are not my people, that there they shall be called, the children of the living God" (G4v). Middleton annotates the passage, "Our Vocation is free, and of grace, even as our Prædestination is." If vocation and predestination, and therefore salvation, is of grace, then conversion and repentance are responses to grace. 
In Middleton's drama, the responses to grace seem to signify the genre. The comedies commonly have important scenes of grace accepted, signified by a character's repentance or conversion. The tragedies commonly have significant refusals of grace. Both types of scenes can occur within one play, as in A Trick to Catch the Old One where Witgood and the Courtesan repent and Dampit blasphemes. Indeed reprobation is the common nature of most characters, comic or tragic. But the generic difference between Middleton's comedies and tragedies is whether the characters accepting or refusing God's grace figure strongly in their play's conclusion, determining whether the play ends with reconciliations and unions or carnage. 2

This distinction of genre on the basis of responses to divine grace can, of course, apply as well to the works of Middleton's contemporaries. We may think of Duke Frederick's reported conversion at the end of As You Like it and the resolutions of Measure for Measure. ${ }^{3}$ In John Ford's Political Theatre, Lisa Hopkins argues that Ford portrays tragedy as the rejection of, or the lack of access to sacramental ritual, the mode of grace in Catholic theology (chapters five and six). In his own dramatic practice, Middleton self-consciously ties the genre of the play to the response to grace, so that any comedy which has been considered a major text in his canon has a repentance or conversion scene.

I conclude that Middleton's connection between grace and genre is selfconscious and intentional because, while he makes this link, he also 
demonstrates the power of drama to mislead, cozen, or seduce. In $A$ Mad World, My Masters, Follywit's comedy "The Slip" is named for a counterfeit coin; while giving his grandfather Sir Bounteous "The Slip," Follywit steals his jewels (V. ii.). The rejected suitors in No Wit, No Help Like a Woman's rewrite Master Beveril's masque of the natural elements to offer insults to the widow Lady Goldenfleece (IV. iii). The wedding masque in Women Beware Women disguises murderers and weapons (V. ii.). And in Hengist, King of Kent, the players who perform for Symonides assault him with a sack of meal and rob him (V. i.). These "plays" within the plays are reflections of the cozenages offered throughout the main plots and subplots; Follywit's Slip is only one of three gullings of Sir Bounteous.

Some performances intended to mislead the other characters are ostensibly given moral purposes, such as Prince Phoenix's disguising to search out evil in his country, Sebastian's dissembling courtship of Moll Cutpurse to win his father's approval of Mary Fitzallard in The Roaring Girl, and Theodorus Witgood's dissembling courtship of the Courtesan in A Trick to Catch the Old One. In these instances where the dissembling is implicitly given authorial approval, a reader could fairly wonder if Middleton is approving of lying in the form of fiction. (That dramas are "lying fictions" is a common antitheatrical argument.) Noting further the congenial portrayals of Follywit, Quomodo, Witgood and others, some critics have regarded Middleton as a decadent Jacobean rather than as a Christian dramatist because they find Middleton approving of roguery and 
dissembling: "He seems to have been largely untouched by conventional religious attitudes and pieties, or at least to have outgrown them at a very early age" (Huebert 607).

The dissemblings that Theodorus Witgood and Sebastian Wengrave perform are already reciprocating; their deceptions bring about the judgements that have been due to Lucre and Hoard and Sir Alexander Wengrave. Lucre, Witgood's uncle, has already cozened Witgood as the play begins; Hoard competes with Lucre in cozenage. Theodorus Witgood exhibits signs of repentance for prodigality in the play's opening scene; that he should also defeat the usurers concurs with his name: "Theodorus" means "gift of God" (which is God's grace). Sir Alexander has prevented the heaven-ordained marriage between his son and Mary by claiming her dowry is too small. Both Theodorus and Sebastian succeed happily through their deceptions, but it would be a leap to conclude from their situations that Middleton approves of deception generally.4

Two general observations about Middleton's genial treatment of rogues can be made here. First, in accord with Middleton's Protestant theology, the victims of the rogues' gullings are not usually their moral superiors. When Master Harebrain declares "All sins are venial but venereal" ( $A$ Mad World, I. ii. 135), his cuckolding by Penitent Brothel recompenses his morally deficient opinion. And in Michaelmas Term, Quomodo's plot reveals and exploits Richard Easy's initial enthusiasm for sodomy (discussed in chapter 
four). Middleton does draw moral distinctions between villains and victims in the tragedies, tragicomedies, and A Game at Chess, but in the city comedies, they are usually immoral equals.

Furthermore, the villains in the comedies finally gull themselves as well. Follywit notes, "For craft recoils in the end, like an overcharg'd musket, and maims the very hand that puts fire to't" (III. iii. 10-12). Of course, he fails to see that the same principle applies to his own cozenages. Once his plot for "the slip" collapses, Sir Bounteous moralizes, "Who lives by cunning, mark it, his fate's cast;/ When he has gull'd all, then is himself the last" (V. ii. 271-272). Follywit concurs: "Tricks are repaid, I see" (V. ii. 261). Similar aphorisms are applied in Michaelmas Term, and the principle is demonstrated throughout Middleton's canon, often referred to as the "biter bit motif." The source for this principle of judgement is the Biblical claim that a person reaps what he or she has sown (Galatians 6: 7), echoed in Thomasine's words in Michaelmas Term, "he that sows in craft does reape in jealousy" (III. iv. 246-247). 5

Middleton's juxtapositions of comedy as a mode of grace and comedy as a mode of cozenage (financial and sexual) corresponds well to the generic perspectives suggested by ancient and Christian sources: dramatic, theological, and literary. Middleton would have known that comedy was used in the religious rituals of the Greeks and Romans. Gail Kern Paster calls Middleton Plautus' "legitimate heir on the Jacobean stage" ("The City" 
30) because both writers specialize in plots involving cozenages, conflicts between youths and the aged, competitions for sexual conquests, and urban settings, Athens and London. England's native tradition in drama also evolved from religious ritual, from the mass into mystery and morality plays. David Farley-Hills proposes that Middleton brings "the long tradition of the morality play to perfection by reconciling moral import with naturalistic medium" (The Comic 81).

While the generic term "city comedy" does not appear in the Renaissance, it helps to point out the Augustinian nature of the city in Middleton's comedy. Middleton cites Augustine on the title page of The Two Gates of Salvation and four times in the margins. His comedy of grace is an interjection into his comedy of cozenage, much like the city of God (civitas Dei ) enters into and spreads through and beyond Augustine's Rome, the earthly city (civitas terrena). Significantly in this regard, Middleton names his London "Troynovant," the new Troy, in Satire V of Microcynicon. London could be seen as a descendant of decadent Rome, which, in turn, descended from Troy. 6

Middleton's plays may also be seen as his own effort at divine comedy. Dante's idea of divine comedy encompassing hell, but going beyond it to the divine, fits Middleton's dramatic practice, though Plautus is closer to being Middleton's guide than Virgil. And if Middleton's congeniality towards his rogues seems incongruent with his faith, Erasmus' The Praise of Folly offers 
another precedent. Erasmus defends his work by arguing, "This liberty was ever permitted to all men's wits, to make their smart witty reflections on the common errors of mankind, and that too without offence, as long as this liberty does not run into licentiousness" (94). Although Middleton does not offer a critical theory of drama as such, his drama itself suggests the cultural influence of Plautus, Augustine, Dante, and Erasmus.

This concept of two comic genres juxtaposed in Middleton's city comedies has long been considered a central problem in Middleton criticism. R. B. Parker identifies "a tension" in his comic style "between skill in the presentation of manners and a desire to denounce immorality" ("Middleton's Experiments" 179). Therefore, Parker concludes,

Middleton's comic world ... has two polarities: a completely amoral vitalism and a more than Calvinistically determined scheme of retribution. He attempts to reconcile them in a strange mixture of realism, irony, and exaggeration, and from either extreme takes refuge in grotesquerie. Whether this problem was a philosophic one or an artistic one rising from technique it is impossible to say.

[199]

The tension Parker identifies between Middleton's amoral presentations and moral purpose, or between conflicting artistic and philosophic commitments, resolve in grotesquerie.

Joseph Messina criticizes Parker's explanation for identifying the tension in a hypothetical split in Middleton's psyche between aesthetic and moral purposes (117). Writing about $A$ Trick to Catch the Old One, Messina prefers to define the conflict as accomplishment: "That there is a strongly moral side and that it exists in tension with a far less moral one is just the 
point" (116). The comments in chapter one about the subordination of moral concerns to theological concerns may apply as well to Messina and other critics who emphasize moral purpose in Middleton's works. Nevertheless, the difference between my views and theirs is not one of contradiction; rather, to emphasize primarily Middleton's moral purpose is to give an incomplete account, rather than a wrong one. While I agree with Messina's criticism of Parker, Parker's unexplored reference to Calvinist determinism-"a more than Calvinistically determined scheme of retribution"-hints at what is incomplete in his own and Messina's reading.

The explanation being developed here of the division of comedy into divine and worldly perspectives runs counter to the majority critical opinion asserting Middleton's supposed secularism in his city comedies. From whatever theory the critics offer Middleton's secularism, their explanations can usually be divided into two forms. First, if the circumstances of a particular repentance or conversion scene are treated with a lack of seriousness (or comically), then the scene has no more claim to moral purpose (or theological point) than the whole comedy in which it appears. About the succubus scene in A Mad World, My Masters, William W. E. Slights states, "When Circe versifies like Ogden Nash, we can be certain that we are still well within the comic framework" (95). Slights observes unnamed "providential forces quite beyond the control of the characters" (93), but the "moral improvement in this play is the result not of 
conscience but of coincidence and asserts itself ... through contrivances of plot" (97).

At least for Slights, moral improvement happens. Michael Shapiro relegates the entire Penitent Brothel plot to a parody of conventions in Dekker's and Heywood's works (122). (Both playwrights are now seen by some critics, myself included, as Calvinist playwrights.) The succubus is "a hallucinatory projection of [Brothel's] old lust, now congealed into remorse" (124). Shapiro concludes,

The sleazy self-righteousness of Penitent Brothel's repentance, the concealment of the true facts from Harebrain, the jingling of the couplets, and the sanctimonious sententiousness of the entire action all suggest that Middleton is parodying a theatrical convention familiar to the spectators and perhaps the popular morality on which it was based. [126]

The only point I will concede in this summary is the jingling of the couplets; otherwise, Shapiro's reading is wholly opposed to the one which I offer. In a sense, Slights' and Shapiro's explanations deny there is a binary conception of comedy as divine and worldly at work in Middleton's plays. Instead, there is only worldliness; religious acts are only one other part of a single comic picture, usually of the perpetual foolishness of the world.

The second form of secularizing explanation for the juxtaposition of comic genres is that the opposed generic ideas bring each other into question. From this explanation, Middleton emerges as a great ironist and skeptic. Claims one critic, "Middleton ... established a moral exemplum and cast doubt upon its validity, not with the polemical end of refuting it, but 
rather with the result that the ironies of such a model in such a world be laid out for the audience's examination" (Root 88). This conclusion has been reached from a variety of critical perspectives.

Stephen Wigler introduces a psychoanalytic reading (Freudian, but not Lacanian) of A Mad World, My Masters by claiming Middleton "indecorously ... mix[es] two contrasting planes of reality: the supernatural or spiritual and the natural or sensuous" (18). "The juxtaposition of the eschatological with the mundane," Wigler labels the "grotesque," which "is created by combining what Freud called the 'uncanny' with a comic component which insulates and distances us from what otherwise would produce anxiety and discomfort" $(18,21)$.

There are conceptions of the grotesque which agree well with Middleton's Christian perspectives and characterizations. Flannery O'Connor never mentions Middleton's work, but her description of the grotesque in Southern fiction is general enough to apply across Christian perspectives, Catholic or Calvinist:

If the writer believes that our life is and will remain essentially mysterious, if he looks upon us as beings existing in a created order to whose laws we freely respond, then what he sees on the surface will be of interest to him only as he can go through it into an experience of mystery itself.... For this kind of writer, the meaning of a story does not begin except at a depth where adequate motivation and adequate psychology and the various determinations have been exhausted. Such a writer will be interested in what we don't understand rather than in what we do.... He will be interested in characters who are forced out to meet evil and grace and who act on a trust beyond themselveswhether they know very clearly what it is they act upon or not. To the modern mind, this kind of character, and his creator, are typical Don Quixotes, tilting at what is not there. ["The Grotesque" 41-42] 
The grotesque in Middleton's characterization of Penitent Brothel comes from exactly the clash of the mundane with the mysterious or divine that O'Connor describes. Brothel does meet evil and grace.

But this is not what Wigler means. Instead, Brothel's conversion is an outlet for distaste with the adultery he has just committed. The audience's enjoyment of Brothel's cuckolding of Harebrain crashes against his remorse, a "disjunction between instinct and conscience" (21). There really is no resolution: "Our amusement is subverted by anxiety and our disapproval is subverted by enjoyment" (21). Wigler works out a similar psychoanalytic reading of $A$ Chaste Maid in Cheapside, where "delight and distaste perpetually contaminate one another" ("The Delicious" 199).

Wigler suggests a source for these unresolved conflicts in Middleton's unconscious ("Penitent Brothel" 21). P. K. Ayers finds more authorial intention in the arrangement of these conflicts. Middleton manipulates "morality-play conventions [to point] to their lack of significance in 'modern' drama, and thus ultimately to the irrelevance of conventional patterns of belief and behavior to the realities of life in the city" (9). Of course, the conventional patterns are Christian patterns. By now predictably, "the mechanism of conversion, a grotesque intrusion of a supernatural apparatus into a domestic context, invites ... skepticism" (8; emphasis added). Brothel's scene with the succubus is for Ayers, therefore, a kind of deconstructive joke that turns reality for the audience inside out: 
Forcing on us the necessity of choosing between competing interpretations of reality, [Middleton] also offers us the opportunity of making fools of ourselves. Thus in the subplot, for example, he opens up the possibility that we may one day find ourselves, like Penitent Brothel, forced to come to terms with the physical reality of a spiritual framework long assumed to be at best a metaphor, and a slightly ridiculous one at that. By emphasizing the creakingly old-fashioned mechanism of the succubus, Middleton in effect discourages us from taking it very seriously; its literal reality, however, must give us pause and lead us to reflect that its apparent irrelevance to the main part of the action and to the way that we have consequently chosen to interpret reality both inside and outside the play may in the end turn out to be a grim joke by Middleton at our expense. [9-10]

If simple error of fact were enough to discredit a strain of interpretation, Ayers' reading and others like it would fall easily. He makes the ubiquitous mistake of identifying the succubus as the instigator of Brothel's conversion when, in fact, Brothel converts before the succubus enters the scene (IV. i. 1-29). Furthermore, he overlooks theatrical history when he calls the succubus a "creakingly old-fashioned mechanism"; ghosts and spirits appear in current and later works by Middleton, Shakespeare, Jonson, Webster, Marston, and others. By dismissing the succubus, Ayers has made Pentitent Brothel into the "typical Don Quixote, tilting at what is not there," as O'Connor characterizes the modern dismissal of Christian grotesquerie (42).

I do not suspect a general bias among critics against reading Middleton as a Christian writer; after all, why read in the English Renaissance at all if one has a disposition against writers who were Christian? But in particular instances, such as Ayers' argument, the basic mistakes the critic makes suggest an overdetermined effort to fashion a secular Middleton. Wigler exhorts his readers, "We should have the humility to recognize that we 
cannot resurrect Thomas Middleton, only perform him" ("Penitent Brothel" 23). Both Ayers and Wigler criticize previous interpretations which acknowledge Middleton's faith. Yet, while we may not resurrect Middleton, we may perform him more truthfully if we acknowledge that he believes in Christ's resurrection, and thus his own. Language like "creakingly oldfashioned mechanism" obfuscates Middleton's evident Protestantism. ${ }^{7}$

This is not to say that Wigler, Ayers, and others deny a moral purpose in Middleton's works. Wigler says that "Penitent's conversion ... provides an outlet for ... distaste" (21), and the "pause" the succubus must give, according to Ayers, is towards spiritual reflection. But these are moral impulses removed from their foundations. Another critic who finds similar clashes of morals and amoralism in the plays, Ronald Huebert, concludes of Middleton, "He is serving a warning, not about what will happen to sinners in the hands of an angry God, but about what we are capable of doing to one another and to ourselves" (609). Middleton does not particularly emphasize God's angry judgement, preferring to demonstrate God's grace in the comedies, but his repeated references to characters reaping what they have sown stems from Biblical principle. Huebert sets up a faulty dichotomy - what we do to ourselves is an example of God's judgement.

The most thorough examination of Middleton's juxtaposition of comic modes of moralism (or grace) and cozenage is George E. Rowe's Thomas Middleton and the New Comedy Tradition (1979). His study ranges from 
The Phoenix (1603) to The Changeling (1622) and includes consideration of the tragicomedies and other lesser-known plays. Rowe's study is a brilliant construction of Middleton's theatrical canon as the work of a decided skeptic: "Middleton's plays systematically undermine New Comedy conventions in order to criticize the assumptions and values which lie behind them and, ultimately, to reject the explanation of existence which the form embodies" (2).

The conventions of Roman New Comedy to which Rowe finds Middleton responding are the plot features delineated by Northrop Frye: a young man pursues a young woman, but he is resisted by a sociallyestablished elder (the senex), who is often the youth's father or other male relative. The difficulties the youth encounters and the subterfuges he devises to resist them form the main action of the play. "The protagonist's victory often represents the symbolic overthrow of a harsh, restrictive society by one which is freer, more accepting, and more inclusive" (Rowe 2).

Middleton, according to Rowe, consistently disrupts these conventions by introducing such features as the Harry Dampit subplot, Sir Walter Whorehound's repentance, and characters with various obsessionsTangle, for law in The Phoenix; Sir Bounteous Progress, for effusiveness in A Mad World, My Masters; Tim, for scholastic logic in A Chaste Maid in Cheapside (6-7). These disruptions are made to show that the value judgements and interpretations of reality inherent in the New Comedy genre are no longer pertinent to Middleton's time: 
In essence, Middleton is testing the view of reality which is implicit in comedy; he is examining its method of explaining human existence. In doing so, Middleton questions almost all important comic values and assumptions, but he reserves special emphasis for two: New Comedy's affirmation of a unified human community and the form's celebration of man's ability to renew himself and his society. [10]

Rowe's emphasis on Middleton's critique of New Comedy suggests a different rubric of primary examination than the usual focus on the opposition of moralism and amoralism. Rowe instead finds, "Idealism is juxtaposed to cynicism; serious concerns mingle with farcical ones" (6). Nevertheless, as his chapter on Michaelmas Term and A Trick to Catch the Old One shows, he does find a connection between "New Comedy and the Parable of the Prodigal Son" (chapter 3). ${ }^{8}$ Rowe claims that by adapting the protagonists Richard Easy and Theodorus Witgood to a prodigal son pattern (following the elements of the parable in Luke 15), Middleton reverses the usual resolution of New Comedy away from a celebration of youth to a reassertion of the established social order. However, the content of that order is ironically problematized: the reformed prodigal youths assert the order while the senex characters Quomodo, Hoard, and Lucre-the usual representatives of the outdated order-actually oppose order. The motivations, furthermore, are all self-interested. New Comedy and the prodigal son parable resolve in opposite directions; by combining their features, both paradigms lose their explanatory power. About Michaelmas Term, Rowe claims, "Because neither the comic nor the Christian pattern finally dominates the drama, its conclusion is ambiguous" (56). Of $A$ Trick 
to Catch the Old One, "Its world seems unable to accommodate some of the central tenets of both Christianity and Roman comedy" (84).

That Middleton would question the explanatory power of New Comedy conventions while using them seems plausible. However, the questioning, according to Rowe, extends to include Christian perspectives, which are thrown into doubt by their clash with New Comedy. In other words, even if New Comedy conventions are subject to skepticism, they retain enough persuasiveness to subject Christianity to skepticism in turn. Chapter four of Rowe's study is titled "Meaningless Forms." The plays with meaningless forms have the best-known repentances of Middleton's canon, of Penitent Brothel and Sir Walter Whorehound, suggesting, of course, that these repentances participate in the general meaninglessness of the worlds or forms in which they are portrayed. If this interpretation looks imposingly negative, for Rowe that is the point: "By now it should be clear that [Middleton's] vision is in fact a resolutely anticomic one" (13). Rowe's study ranges through eleven plays spanning Middleton's dramatic career, constructing it as an effort to debunk or question literary and religious tradition. As to whether or not Middleton was himself religious, Rowe's fullest consideration of the question is, "As far as is known, Middleton, if he was a Christian, was a member of the Church of England" (223). And this is given in an endnote.

Later research on Middleton's canon again raises questions (which have not necessarily been asked). If for Rowe, Middleton's anti-comic 
vision builds up to the tragic perspectives realized in Women Beware Women and The Changeling, then his argument is not helped by the current attribution of significant tragedies to Middleton dating before $A$ Chaste Maid in Cheapside (1613).9 But a problem of definition in Rowe's argument could have been identified even by reference to Northop Frye. Commenting on Rowe's examination of $A$ Chaste Maid, Joanne Altieri holds up Aristophanic satiric comedy as a generic antecedent for Middleton's (and Jonson's) comic oeuvre, undercutting Rowe's reliance upon New Comedy patterns (174). As Altieri correctly notes, for Rowe, New Comedy is comedy. But even though Frye consigns Aristophanes and his descendants to the mythic winter (cold, unfeeling, unromantic) end of comic genres, at least that end exists (Altieri 173). It ceases to be comedy when Rowe applies the definitions.

Part of the discontent, disorientation, or even anxiety which the critics find Middleton provoking in his comedies results from the wrong presuppositions readers bring to his works-about the relationship between Jacobean Reformation Christianity and theatre, about the priority theology can have over morality. But an assertion of Middleton's Christianity cannot gloss over the gross physicality of orgasmic noise, inebriation, and incontinence in the plays. Disorientation and anxiety are expected responses to the mad worlds Middleton portrays. The humor of $A$ Chaste Maid in Cheapside is indeed, as Wigler claims, delicious and disgusting. 
The thesis that the portrayal of grace signifies the genre of Middleton's comedy depends upon demonstrating two points. First, the repentance or conversion scenes should have a coherence which can be explained in Protestant theological terms. Theology is omitted in the arguments like those offered by Slights and Shapiro, who read these scenes naturalistically as the self-interested activities of characters participating in the general worldliness of each play. They find little or no difference between the motivations of Penitent Brothel and Sir Walter Whorehound while repenting and the motivations of Follywit and Allwit while scheming. The inclusion of theology will both reveal the difference and also reveal certain patterns common to the repentance scenes.

The second point is that the Protestant theology which explains the repentances should also explain the reprobate activities of the unrepentant characters. To show that the repentances follow a common theological pattern is not to answer Rowe and others who find mutually cancelling juxtapositions and meaningless forms in the plays. While these critics also omit theology from their arguments, they could respond that Middleton in fact questions the Protestant theology of the repentance scene by his juxtapositions. Middleton does indeed satirize precisianist Puritanism and attack Catholicism. Yet if the Protestant theology of the repentance also informs our reading of the reprobate activities, then the juxtapositions resolve, not in meaninglessness, but in a theatrical representation of Christian belief. 
While I am claiming that Middleton takes seriously the need for, and act of, repentance, I am not claiming that the representations are somber. The comedy of grace is comic. The silliness of the succubus pursuing Penitent Brothel, therefore, does not have to clash with the scene's underlying significance. Furthermore, there is a skepticism evident in Middleton's work, but he takes his faith as the basis of questioning. His use of grace introduces its own kind of irony because grace in Calvinist theology is unpredictable. It does not necessarily favor the most attractive or strongest character.

As the most controversial play with a repentance, A Mad World, My Masters will be examined first to demonstrate the Calvinism pervading Brothel's repentance and the portrayal of the mad world. Brothel's repentance is also paradigmatic; it reveals a pattern which most of Middleton's other repentances follow. References to The Widow, with Francisco's repentance, will point out the similarities. The Widow was written around 1616, after the 1613 date some critics (following Heinemann) use to mark the beginning of Middleton's Christian productions. I instead suggest that the similarity of the repentances in these plays, written ten years apart (c. 1606 and 1616), suggests a continuity of Christian thought which must cast doubt on secularized readings of the early city comedies.

A Chaste Maid in Cheapside is the one comedy in which the material circumstances of the penitent worsen: Sir Walter Whorehound gets sent to the debtor's prison. This has often been read to suggest the ineffectiveness 
of his repentance. But other Christians suffer in Middleton's tragediesHelvetius is imprisoned in The Second Maiden's Tragedy and Constantius is martyed in Hengist, King of Kent - and the repentant Husband is executed in $A$ Yorkshire Tragedy (albeit offstage). Sir Walter's imprisonment may say more about the values of the profane society in which he is portrayed than about the effectiveness of his repentance. Middleton's greatest accomplishment in comedy evokes a society almost devoid of theological and moral awareness, but suffused with reminders of a Christian spiritual reality: a christening, a "resurrection" of Moll and Touchwood Junior, its lenten setting. The grossness of $A$ Chaste Maid is revealed from a Christian perspective, one which also suggests the value of repentance, regardless of Sir Walter's imprisonment.

II. From Brothel to Once-IIl: Penitent's Paradigmatic Conversion in A Mad World, My Masters

One problem with $A$ Mad World, My Masters is the meaning of the title: What makes this a mad world and how is that madness a subject of instruction to "my masters"? Arthur Marotti identifies the madness with "the monomania of the characters and the playworld's comic disorder" ("Method," 99). The monomania is manifested in Sir Bounteous Progress' extravagant display of wealth in generosity, Follywit's robberies of his grandfather, Harebrain's sexual jealousy of his wife, and Penitent Brothel's corresponding determination to mate with Mistress Harebrain. Marotti further identifies the madness with the "confusion of illusion and reality," a 
main theme of the play (102-103). Disguisers and pretenders in the play include Follywit and his subordinates, Penitent Brothel and Mistress Harebrain, and the Courtesan (who is ready to market her sixteenth virginity; I. i. 149-151). Sir Bounteous Progress deceives himself, but nobody else, about his sexual capabilities.

Epistemological confusion is matched by ontological confusion, manifested in the oxymorons of character names: Folly/wit, Penitent / Brothel, and the Courtesan Frank / Gullman. There is also a disjunction in Bounteous Progress' name between charity, expressed in bounteousness, and pride, revealed in the ostentatious display of a progress (a state procession). What can be regarded as the truest state of being for these characters? All of them are implicated in the madness of the mad world, and so, Marotti concludes, is the audience: "The members of Middleton's audience are forced to recognize their intellectual limitations and feel that the epistemological obscurity which envelops the characters of his comedy affects them also" (106). Like Wigler and Ayers, Marotti locates overriding irony and skepticism in the play. But like Slights and Shapiro, he bases his argument on the madness pervading the whole work, including Penitent's conversion, "as ridiculous in its own right as his previous cliché libertinism" (102). He does not quote from Act IV, scene $i$, the conversion scene, but he claims that at "Penitent Brothel's discomfiture[,] the full ridiculousness of his name [is] by now quite apparent" (102). 
But what is Penitent's name at Act IV, scene i? The stage directions opening the scene in the first and second quartos (1608 and 1640) read,

Enter in his chamber out of his studie, Master Pœnitent, Once-Ill, a Booke in his hand reading.

The stage directions opening Act IV, scene iv, read "Master Ponitent Once-Ill knocking within; enter a seruus" (from UMI microfilm of the 1608 quarto). In his 1963 dissertation, Michael Taylor has proposed that "Once$\mathrm{nl}$ " be taken as a descriptive adjective, separated at IV. i. by a comma from "Pœnitent" (cited by Saccio, Textual Notes).10 But "Once-Ill" appears like a surname at IV. iv, and it maintains a descriptive sense requiring an explanation.

No modern editor has kept the reading of "Once-Ill," and its relegation to textual apparatus has resulted in a lack of consideration in the criticism. In his forthcoming edition of $A$ Mad World, Peter Saccio claims the new surname "reflects the character's change of heart and it echoes 'Brothel': it is thus probably authorial." Yet Saccio follows the previous editors by emending "Once-Ill" to "Brothel," reasoning, "Since Penitent's surname occurs nowhere else in the final acts, ... the variant is trivial and has no effect in stage performance" (Textual Introduction). 11

The problem of name changes also affects the Harebrains. They become "Hargraves" in both stage directions and spoken texts throughout Act IV, and in Act V, Master Harebrain becomes "Shortrod" in both spoken texts and speech prefixes. Because speech prefixes are typically abbreviated in 
early play texts, it is impossible to tell whether "Har." is meant for Harebrain or Hargrave, but at IV. iv. 90, the abbreviation is "Harg." All of this reflects the "indeterminacy posible in early modern play-texts"; Saccio solves this problem by keeping the original surnames, and treating "Shortrod" as Harebrain's first name: Master Shortrod Harebrain (letter).

Standish Henning, editor of the Regents Renaissance Drama edition, admits, "If the alternate names were the result of Middleton's second thoughts while he was writing the play, they would fall into the category of authorial indecision or haste which marks foul papers" (xviii). Yet other errors not notable before Act IV—misspellings, missed stage directions, and faulty pronoun references-show evidence that the switch in names coincides with a switch of compositors to one who was "careless, inexperienced, or very hurried" (xviii). Henning concludes,

If it were not for the egregious literal errors it might be supposed that the printer's manuscript were radically different after sheet $E$, becoming much harder to read and to interpret, but this compositor's incompetence is manifest. It thus seems likely that the variations in the characters' names result from his inability to cope with a moderately ambiguous manuscript. [xix]

The problem with Henning's conclusion is that the text, whether the printer's manuscript or the "text" represented by the various editions available today, is indeed radically different after sheet $\mathrm{E}$ and harder to interpret-because of the repentances of Penitent and Mistress Harebrain. Because "Hargrave" means "hare grove," the change from "Harebrain" to "Hargrave" could perhaps result from the compositor's confusion of words 
based on "hare." However, no similar confusion can explain the switch from "Brothel" to "Once-Ill," and faced with this switch, the compositor might have dropped Penitent's name altogether from the spoken text in Acts IV and V. Three times his name is conspicuously missing from the spoken text where its presence would be expected during a performancewhile the Succubus tempts him (IV. i. 30-72), when Harebrain first meets him (IV. iv. 77-90), and when Harebrain introduces him to Bounteous Progress as "an especial dear friend of ours" (V. i. 11).12 Henning may have the cause and effect reversed; rather than taking the errors as evidence that the compositor introduced variants in the characters' names, we may instead conclude that the errors the compositor made resulted from working with a text with intentional variations, in characterization and in names.

I surmise that Middleton intended these substantive name changes, neither indecisively nor as second thoughts, but to express the character transformations. I further believe that "Once-Ill" was used as a new surname for Penitent in early performances, especially in the scenes where his name is missing. Middleton does not use similar name changes for converts and penitents in his other plays, but Penitent's conversion is paradigmatic, and his name change has significant Biblical precedentsAbram becomes Abraham when he is circumcised (Genesis 17), Jacob becomes Israel after wrestling with the angel (Genesis 32) and with even closer parallels, Saul becomes Paul after the conversion of his first Gentile 
follower (Acts 13: 4-12). Henceforth, I will use "Penitent Brothel" only when discussing Acts I-III, and simply "Penitent" for Acts IV and V.

Even if "Once-IIl" should be taken as a descriptive adjective rather than a name change, as Michael Taylor has proposed, it does not seem to refer to a state of recovery from a physical illness. "Once-nll" contrasts with the madness of the title in which Penitent has been implicated by his surname "Brothel." Ilness has a metaphorical association with both madness (mental illness) and sinfulness, a sickness of one's soul. The association of illness and sinfulness appears throughout the Bible and is maintained in The Two Gates of Salvation.

From the "first gate," Middleton cites Isaiah 53: 4: "Surely he hath borne our infirmities, and carried our sorrowes, he was wounded for our transgressions, broken for our iniquities, the chastisement of our peace was upon him, and with his stripes we are healed" (C3v). In Christian tradition, this is usually taken as a Messianic prophecy of the salvation Christ effects through the crucifixion. This comes to include the healing of the sick when Isaiah is cited in Matthew 8: 16-17, the corresponding "second gate": "They brought unto Jesus, many that were possessed with Divels, and he cast out the Spirits with his word, and healed all that were sick, that it might be fulfilled which was spoken by Esayas the Prohphet, saying: He tooke our infirmities, and bare our sicknesses" (C4r).

Later, using the Biblical typological trope of "leprosy" for sinfulness, Middleton quotes Matthew 8: 2-3: "And loe there came a Leper and 
worshipped, saying: Maister, if thou wilt, thou canst make me cleane. And Jesus putting forth his hand, touched him, saying: I wil, be thou cleane, and immediatly his leprosie was clensed" (D2r). His annotation is, "In this, Christ shews, that he abhorreth no sinner, that comes unto him, be he never so uncleane."13

Sinfulness, figured as sickness, is regarded in Calvinist theology as humanity's natural state. Commenting on the evidences for human corruption given in Romans 3: 10-18, Calvin states in the Institutes,

If these are the hereditary properties of the human race, it is vain to look for anything good in our nature.... [1]t cannot be denied that the hydra [of vice] lurks in every breast. For as a body, while it contains and festers the cause and matter of disease, cannot be called healthy, although pain is not actually felt; so a soul, while teeming with such seeds of vice, cannot be called sound. [I: 251]

The madness which Middleton asserts is characteristic of the world cannot be categorized as mere psychosis. Sinfulness conflates with sickness, as does madness, which are all humanity's natural state. The words and cognates of "sin," "nature," "sickness," and "madness" are used throughout A Mad World, My Masters, and Penitent's conversion and transformation from "Brothel" to "Once-Ill" must be taken as signifying a change in relationship to his natural, sinful, mad state.14

What distinguishes Penitent Brothel before his conversion from the play's other characters is his moral awareness. Charles Hallett claims that in Penitent Brothel's character Middleton combines a presenter-satirist, like the moralists Prince Phoenix and Fitzgrave (from The Phoenix and Your Five 
Gallants), with an Everyman figure, such as he created with Richard Easy, the protagonist of Michaelmas Term (67-70). Such a combination is manifested by a character who participates knowingly in the very follies he condemns in others. In Act I, Penitent Brothel judges Follywit:

Here's a mad-brain o'th' first, whose pranks scom to have precedents, to be second to any, or walk beneath any mad-cap's inventions; h'as play'd more tricks than the cards can allow a man, and of the last stamp, too; hating imitation, a fellow whose only glory is to be prime of the company, to be sure of which he maintains all the rest. He's the carrion, and they the kites that gorge upon him.

[I. i. 83-89]

Usually when commenting on Follywit's character, critics will cite the lesscondemning lines which follow these. Yet the apex of madness in this play is Follywit, "a mad-brain o'th' first" who "scorn[s] ... to be second to any" in creating fraudulent escapades. In his effort, Follywit maintains Mawworm and Hoboy, the "kites" that feed on his success.

There is an attractiveness in Middleton's characterization which Rowe reads as "vindication of Follywit's knavery as 'time's comic flashes"' (98). But "time's comic flashes" must be read in the context both of the section of speech cited above and the "wild passions," "common receiv'd riot," and "fruits of blood" that Penitent Brothel further attributes to Follywit as he turns his attention to his own desires:

But why in others do I check wild passions, And retain deadly follies in myself?

I tax his youth of common receiv'd riot, Time's comic flashes, and the fruits of blood; And in myself soothe up adulterous motions, And such an appetite that I know damns me, Yet willingly embrace it: love to Harebrain's wife, Over whose hours and pleasures her sick husband, 
With a fantastic but deserv'd suspect,

Bestows his serious time in watch and ward. [I. i. 90-99]

After observing Follywit's profligacy, Penitent Brothel confesses to his own follies. This self-interrogation parallels the question Jesus subjects his listeners to: "Why beholdest thou the mote that is in thy brother's eye, but perceivedst not the beam that is in thine own eye?" (Luke 6: 41). Far from being morally superior for his awareness, Brothel embraces his damnation by embracing Mistress Harebrain.

Thus he minimizes the distinctions between himself and Follywit because the "common receiv'd riot" is his own as well. David Farley-Hills suggests that Brothel "is already 'converted' in the sense that he is fully aware of his sinful state and wishes to be otherwise when the play begins" (103). The problem with his awareness is that his will is corrupt: "[I] soothe up adulterous motions,/ And such an appetite that I know damns me" (I. i. 94-95). If he is already converted at this point, then as Farley-Hills concludes, "Penitent's would seem to be a case of the backsliding of one of the elect" (103). This would imply, however, that the elect never exist in an unregenerate state. While the election of the saints may be unconditional and God's grace irresistible (making the conversion of the elect inevitable), the initial state of any person, elect or not, is total depravity. Awareness that his will is overcome by appetite makes Brothel even more culpable; knowing that he is damned does not mean that he is not damned.

Little consideration has been given by other critics to Hallett's reading of Penitent's conversion in terms of Renaissance psychological theories of 
the will. The wit and the will are components of one's rational soul; the wit, consisting of reason and understanding, is supposed to direct the choices of the will (70-71). However, the counsel of the wit can be subverted when the will is ruled by its appetite:

In the Penitent Brothel of Act I [Middleton] shows us a man who at some past date has perceived an object called, significantly enough, Mistress Harebrain, has allowed his imagination to dwell upon the pleasurable image of that object and has conceived an unconquerable lust to possess it, which has resulted in the alignment of his will with his appetite. All of this Penitent knows very well. He knows that his desire for Mistress Harebrain, begot of his fancy and nourished by his appetite, is a passion that should be suppressed. But his wit is weak, and his will has become the handmaid of his desire. [75-76]

After condemning Follywit and himself, Penitent Brothel runs though the main characters of his plot, observing their own corruption and misalignment of wills. Harebrain is a "sick husband" with "a fantastic suspect" (I. i. 97-98). The Courtesan "knows no mean" (temperance) and is a poison (101-102); her Mother is a bawd (111). Mistress Harebrain is another poison (102). Yet when the Courtesan offers to manage Brothel's rendezvous with Mistress Harebrain, he makes a conscious decision to follow her course: "I am arriv'd at the court of conscience! A courtesan! Oh admirable times! Honesty is removed to the common place" (I. i. 125-126). In the mad world where illusion is preferred over reality, Penitent Brothel becomes, willingly, a leading participant.

The plot to get Penitent Brothel together with Mistress Harebrain involves two illusions, the first parodying the religious behavior of the separated brethren, the second emblematizing the conflation of sickness and 
sin in the sickroom scene (III. ii). Maintaining the first illusion requires the Courtesan, aptly named Frank Gullman, to insinuate herself into Mistress Harebrain's company under her husband's watchful eye. ${ }^{15}$ The Courtesan's Mother states the "first rules" (I. i. 171) for this charade:

Be wisely tempered and learn this, my wench, Who gets th' opinion for a virtuous name May sin at pleasure, and ne'er think of shame. [I. i. 167-169]

The Courtesan helps Mistress Harebrain achieve the "opinion for a virtuous name" by pretending to be a chaste religious instructor whom Harebrain hires to be his wife's companion. Harebrain's method for guarding his wife's chastity is to keep her at home.

Yet Harebrain's sense of religion is based entirely on outward demonstration, not on an inward resolution. Thus, for example, when he observes the Courtesan instructing Mistress Harebrain, he appreciates, "How earnestly she labors her, like a good wholesome sister of the Family" (I. ii. 67-68). The "Family" here is the Family of Love, an Anabaptist sect which held that their sanctification makes them incapable of committing sin; therefore, they could engage in otherwise illicit sexual activities with impunity. ${ }^{16}$ The appearance of wholesomeness is enough for Harebrain, even while the actual instruction the Courtesan is giving his wife, outside of his hearing, is "to dissemble well" (75) so that she can meet with Brothel.

Part of maintaining the semblance of chastity is to feign the reading of religious texts. The Courtesan further directs Mistress Harebrain, 
If he chance steal upon you, let him find

Some book lie open 'gainst an unchaste mind, And coted scriptures, though for your own pleasure You read some stirring pamphlet, and convey it Under your skirt, the fittest place to lay it. [I. ii. 86-90]

Some books, including annotated (coted) scriptures, lie in the open; another lies under the skirt, with the suggestion of its phallic use-"the fittest place to lay it." The outwardly open books may tell against the inwardly unchaste mind, yet to no effect until they are read.

Harebrain has his own ideas about which texts are which. He conveys away Marlowe's Hero and Leander and Shakespeare's Venus and Adonis, "two luscious mary-bone pies for a young married wife" (I. ii. 43-45). This direct reference to Venus and Adonis (44) can support reading an earlier speech of the Courtesan as an allusion to the poem. As Sir Bounteous' Courtesan, she refers to him as her keeper:

He's my keeper indeed, but there's many a piece of venison stol'n that my keeper wots not on; there's no park kept so warily but loses flesh one time or other, and no woman kept so privately but may watch advantage to make the best of her pleasure. And in common reason one keeper cannot be enough for so proud a park as a woman. 131-137]

In Shakespeare's poem, Venus addresses herself to Adonis:

"Fondling," she saith, "since I have hemm'd thee here Within the circuit of this ivory pale, I'll be a park, and thou shalt be my deer.

Feed where thou wilt, on mountain or in dale;

Graze on my lips; and if those hills be dry,

Stray lower, where the pleasant fountains lie.

Within this limit is relief enough,

Then be my deer, since I am such a park;

No dog shall rouse thee, though a thousand bark."

[229-240] 
Both the Courtesan and Venus claim to be deer parks, but for the Courtesan, there is no single Adonis: "One keeper cannot be enough" (136). The play's audience would be further reminded of Shakespeare's Venus by the aural similarity of Venus/venison: "There's many a piece of venison stol'n" (132).

Imagery such as the comparison of the woman to a garden in the Song of Solomon (4: 12-5: 1) suggests the thinking behind this metaphor is commonplace. However, the ironies of Harebrain's plans to guard his wife compound if, while removing the text of Venus and Adonis, the audience connects Venus with the Courtesan. Sir Bounteous Progress later makes explicit the connection when, believing himself to have impregnated the Courtesan, he explains her illness, "I see by her 'tis nothing but a surfeit of Venus" (III. ii. 43). Therefore, after removing a representation of Venus in erotic literature, Harebrain admits another Venus whom, because of her demeanor, he mistakes for a pure virgin (I. ii. 58). 17

The text Harebrain prefers for his wife's instruction is Robert Parsons' The First Book of the Christian Exercise Appertaining to Resolution (1582), commonly known as the Resolution. He asks the Courtesan to read it to his wife:

There's a chapter of hell 'tis good to read this cold weather. Terrify her, terrify her; go read to her the horrible punishments for itching wantonness, the pains allotted for adultery; tell her her thoughts, her very dreams are answerable.

[I. ii. 48-52]

Harebrain's request fits the tenor of Parsons' text, which does indeed recommend the contemplation of eternal judgements for one's sin; chapter 
nine tells "Of the paynes appointed for sinne after this lyfe, and of two sortes of them" (A5r).

However, Harebrain's preference for this text, with his stated reason for its usefulness, stands in stark contrast to his general religious opinions. Later in the scene, the Courtesan complains that she cannot persuade his wife against the idea "that every sin is damn'd" (I. ii. 123). Harebrain reproves his wife in richly ironic language:

For shame, be converted. There's a diabolical opinion indeed. Then you may think that usury were damn'd; you're a fine merchant, i' faith. Or bribery?... Or sloth?... Or pride?... Or gluttony?... Your only deadly sin's adultery....

'Tis only lechery that's damn'd to th' pit-hole;

Ah, that's an arch-offense; believe it, squall,

All sins are venial but venereal.

[I. ii. 125-135]

What makes Harebrain hare-brained? It is not only that he can be so easily fooled about his wife's fidelity. He also confuses the display of piety with Christian faith. Then he tries to "convert" his wife to the opinion that the wages of sin, except for adultery, is not death (contra Romans 6: 23); he thereby relegates to "diabolical opinion" a major Christian doctrine.

Furthermore, Harebrain's choice of Parsons' Resolution suits his blurring of religious distinction. Robert Parsons (1546-1610) was well known as a Jesuit controversialist and Continental exile. In 1580, he accompanied Edmund Campion in his covert ministry to recusant English Catholics until Campion's arrest. Two years later, he tried unsuccessfully to persuade Philip II of Spain to invade England and re-establish Catholic rule. Yet, despite what most English Protestants would have regarded as Parsons' 
recalcitrance, two of his devotional works, the Resolution and its sequel $A$ Christian Directory, were adapted for a Protestant audience. Over forty editions of these two adaptations were printed by 1627 . The initial 1584 Protestant adaptation of the Resolution begins with a dedication to the Archbishop of York commending the work while faulting the author for adhering to the Catholic faith when his views are so close to the Protestant truth. 18 Harebrain's choice of a text that famously straddles the line between Catholicism and Protestantism magnifies his failure to distinguish the practices of a radical Anabaptist sect (the Family of Love) from those recommended by a dissident Jesuit. Harebrain is hare-brained because, in a culture in which controversy always involves religious perspectives, and religious commitment can establish one's social status, he is completely uninformed. His ignorance, moreover, is marked as the result of moral depravity, his failure to observe the wages of $\sin$.

Mistress Harebrain's imitation of the separatist sects, directed by the advice of the Courtesan, succeeds in duping Harebrain in Act III, scene i. The Courtesan has instructed Mistress Harebrain,

Perhaps he will solicit you, as in trial, To visit such and such: still give denial. Let no persuasions sway you; they are but fetches Set to betray you, jealousies, slights, and reaches. Seem in his sight to endure the sight of no man.

[I. ii. 78-82]

Following this advice, Mistress Harebrain subverts Harebrain's intention to guard her chastity by home imprisonment. When Inesse and Possibility 
visit Harebrain, he plans to test his wife's behavior in their company, but she keeps to her room. Harebrain reproves himself:

Fool that I am, and madman, beast! what worse?

Suspicious o'er a creature that deserves

The best opinion and the purest thought;

Watchful o'er her that is her watch herself;

To doubt her ways, that looks too narrowly

Into her own defects. [III. i. 66-71]

At Harebrain's own persuasion, Mistress Harebrain finally agrees to visit the Courtesan, who is feigning an illness; yet she refuses the accompaniment of any man except her husband. Of course, by escorting his wife, Harebrain unwittingly assists his own cuckolding.

The use of religious texts to gull Harebrain also achieves its desired results. After praising his wife's virtue, Harebrain further observes,

Come I at unawares by stealth upon her,

I find her circled in with divine writs

Of heavenly meditations; here and there

Chapters with leaves tuck'd up, which when I see,

They either tax pride or adultery.

Ah, let me curse myself, that could be jealous

Of her whose mind no sin can make rebellious.

[III. i. 75-81]

Earlier, Harebrain included pride in the sins which are not deadly, venial but not venereal. This contrasts with the conventional view that pride is the chief of the deadly sins, personified in The Faerie Queene by Lucifera leading the procession of sins. The inclusion of texts against pride here again undercuts Harebrain's theologically-deficient bourgeois moralism.

The conflation of sinfulness and sickness is brilliantly emblematized in perhaps the bawdiest scene of Middleton's comedies. The Courtesan fakes a 
serious illness, and Brothel pretends to be her doctor. Their intentions are, first, to gull Inesse and Possibility by getting them to pay for the treatment, and second, to give Brothel and Mistress Harebrain an opportunity to meet while she purports to visit the ill Courtesan. This conflation is anticipated when the Courtesan first describes her plan: "Puh, all the world knows women are soon down.... "Tis the easiest art and cunning for our sect to counterfeit sick, that are always full of fits when we are well" (II. v. 28, 32-33). Henning annotates "sect" as a pun for "sex," combining a term signifying a deviant religious group (such as the Family of Love) with an expression of devious sexual intention in counterfeiting sickness. 19

The conflation continues when Sir Bounteous Progress visits his supposedly ill Courtesan. When he sees the object of his desire, he is suddenly reminded of the wages of sin, the Courtesan's body becoming the entrance to hell:

Here's a sight able to make an old man shrink; I was lusty when I came in, but I am down now, i' faith. Mortality! Yea, this puts me in mind of a hole seven foot deep, my grave, my grave, my grave. [III. ii. 23-26]

If there is any spiritual benefit from being reminded of one's mortality (even expressed in such an ungenerous and egocentric way), that benefit is soon lost when Sir Bounteous thinks of a more vainglorious reason for the Courtesan's illness: "A young Progress when all's done.... I see by her 'tis nothing but a surfeit of Venus, i' faith, and though I be old, I have gi'n't her" (III. ii. 41, 43-44). 
In $A$ Chaste Maid in Cheapside, during his repentance scene, Sir Walter Whorehound regards his bastard children as signs of his damnation (V. i. 69-75). Death is linked with birth in Calvinist theology by the genetic inheritance of original sin:

After the heavenly image in man was effaced, he not only was himself punished by a withdrawal of the ornaments in which he had been arrayed-viz. wisdom, virtue, justice, truth, and holiness, and by the substitution in their place of those dire pests, blindness, impotence, vanity, impurity, and unrighteousness, but he involved his posterity also, and plunged them in the same wretchedness. This is the hereditary corruption to which early Christian writers gave the name of Original Sin, meaning by the term the depravation of a nature formerly good and pure. [Institutes I: 214]

Morning sickness, the Courtesan's "surfeit of Venus," could easily be considered part of the sorrows (along with labor pains) to which Eve and all women are subjected in Genesis 3: 16: "I [God] will greatly multiply thy sorrow and thy conception; in sorrow thou shalt bring forth children." Sir Bounteous' mistaken joy in his own supposed fertility is only the more vain interpretation of the same link of sin and sickness which earlier makes him fear the seven-foot hole. This fear, by the way, echoes Harebrain's earlier assertion, "Your only deadly sin's adultery.... 'Tis only lechery that's damn'd to th' pit-hole" (I. ii. 131, 133).

Following the departure of Sir Bounteous, Mistress Harebrain arrives, ostensibly to console the Courtesan while her husband waits outside. The representation of orgasm in this scene sets the limit of sexual explicitness in Jacobean dramatic texts; I know of no other Elizabethan or Jacobean drama where the audience may be so sure that at the very moment, copulation is 
occurring. This scene is frequently cited as an example of Middleton's own immorality or amorality. As Harebrain listens at the door, the Courtesan feigns a conversation with Mistress Harebrain, who is meanwhile committing adultery with Penitent Brothel:

Pray sit down, there's a low stool. Good Mistress Harebrain, this was kindly done; - huh-give me your hand;-huh-alas, how cold you are. Ev'n so is your husband, that worthy, wise gentleman; as comfortable a man to woman in my case as ever trod-huh-shoeleather. Love him, honor him, stick by him. [III. ii. 179-184]

A few lines later, the Courtesan describes Mistress Harebrain as weeping in pity for her sickness: "Still, still weeping? - [Sobs. ] Huff, huff, huff. -Why, how now, woman? Hey, hy, hy, for shame, leave. -Suh, suh. -She cannot answer me for snobbing [sic]" (197-199). Then the Courtesan speaks of Mistress Harebrain examining her: "Oh no, lay your hand here, Mistress Harebrain. Ay, there; oh, there, there lies my pain, good gentlewoman. Sore? Oh, ay, I can scarce endure your hand upon't" (203-205). Michael Taylor annotates these last lines as describing the activities occurring between the lovers.

With sexual activity more explicitly performed on the modern stage, we may imagine performances of this scene which would emphasize the presence of Penitent Brothel and Mistress Harebrain. ${ }^{20}$ To draw out the farcical possibilities of the text, suppose that both performers were shown backlit behind a screen, bouncing on a bed, tearing up the sheets, and squealing. The Courtesan, centerstage, would try to accommodate by 
matching her dialogue and moans to theirs. Meanwhile, as written in the text, Harebrain would listen in at the Courtesan's door, praising his wife for her tenderness and hoping for the full recovery to health of her fine teacher. Such a staging would suit the meaning of the text, and with the frequent emphasis on the obscenity of this scene, I suppose this approximates how the critics imagine its performance.

The emphasis on the obscenity, however, overlooks the moralism implicit in the scene. Brothel and Mistress Harebrain exit at line 174. Though the Courtesan's huhs, huffs, and suhs represent the lovers' noises, the lovers themselves are silent in the text from line 174 until line 223; noises offstage or "within" are not indicated. Therefore, the focus of attention is on the Courtesan herself, and she expresses the lovers' sexual activity in terms of sickness, pain, and weeping. Perhaps some of the noises even suggest nausea, recalling the possibilty of morning sickness. This is obscenity with its own vengeance inherent-this obscenity is indeed a sickness. In contrast, the common expression of obscenity at least implicitly denies the moral strictures it violates. ${ }^{21}$ The scene concludes with Brothel and Mistress Harebrain re-entering and setting a date for their next rendezvous. Harebrain, no wiser, praises the virtue of the Courtesan and urges his wife to visit her more often.

After this portrayal of sin as sickness, Penitent next enters at IV. i. as Once-III. Every repentance in Middleton's drama begins with the penitent's 
recognition of his or her sinfulness, usually after encountering a reminder of mortality and of the sin committed. In some plays, such as $A$ Mad World, My Masters and Michaelmas Term, the pattern of events at the time of and following the repentance directly contrasts to the process of the sinful activities.22 In Michaelmas Term, the reversal of the sinful activity is indicated as "undoing" the sin (discussed in chapter four).

The first contrast in Penitent's activities comes when, for once, he reads a text: "Ha! Read that place again. 'Adultery/ Draws the divorce 'twixt heaven and the soul"' (IV. i. 1-2). Thus far, texts have been used to convince Harebrain of his wife's chastity. Now the text is read, and it refers directly to the sin for which Penitent repents. No source has been identified for the line he reads, but the line itself matches the description Harebrain gives of Parsons' Resolution, with the "chapter of hell" listing "the horrible punishments for itching wantonness, the pains allotted for adultery" (I. ii. 49-51). Parsons himself writes,

Besides these generall paynes common to all that be in that place, the scripture signifieth also that there shal be particular torments peculiar bothe in qualitie and quantitie to the sinnes and offences of eche offender.... As there be diferences of sinnes, so shall there be varietie of torments, ... for the adulterer shall have one kynde of torment. [1582 edition, 136]

This devotional meditation is close in tenor to Harebrain's description and the claim that "Adultery draws the divorce 'twixt heaven and the soul." Therefore, Middleton's first audiences would have likely inferred that Penitent is reading and responding to the Resolution or a similar text. ${ }^{23}$ 
If so, then Penitent's conversion is, on the one hand, prompted by a text which crosses the Catholic-Protestant divide, but, on the other hand, the conversion is expressed in terms of Reformist theology. However much Middleton militates against Catholicism and the Jesuits in later works, Parsons' Resolution or its Protestant adaptation seems agreeable to his religious perspective in 1606 . Thus far, I have not categorized Middleton's views beyond militant, Calvinist Protestantism. However, a Protestant adaptation of a Jesuit work is more characteristic of an Anglican perspective than the separatist Puritan perspective which Middleton often parodies. The militant Protestants Julia Gasper discusses in The Dragon and the Dove do not attack the Prayer Book nor the office of bishop (5); neither does Middleton. Furthermore, Middleton offers homage to St. Paul's Cathedral in The Triumphs of Truth. It is safe to assume that Middleton remained in the Anglican fellowship, but with a strongly reformist agenda. George Rowe's suggestion that Middleton might have been an Anglican "if he was a Christian" (223) is far too dismissive to be credited with insight.

While Penitent's conversion is paradigmatic in Middleton's canon, it is a paradigm that resists extremes. Penitent does not become a Catholic, but what is less obvious to some critics is that he also does not become a Malvolio or a Tribulation Wholesome; in Act V, he attends the play at Sir Bounteous' house. About his conversion, Robert Root claims that, "We must acknowledge that such pious concerns are an extreme reaction peculiar to Penitent-one need not become a saint to avoid being an adulterer" (88). 
But Protestant conversions in Renaissance texts should not be bracketed off as representing an extremist position. By situating Penitent's conversion between Catholic and separatist Puritan perspectives, Middleton delineates his own via media. Of course, the via media was always an unstable verbal construct, and with his reformist commitments, Middleton's via would not have been media enough for Ben Jonson. But in affirming the need for confession of one's fallenness to establish and maintain a relationship with God, Middleton is no more extreme on this point than Donne, Herbert, or even Jonson: "Is it interpreted in me disease,/ That, laden with my sins, I seek for ease?" ("To Heaven" 3-4).24 And from a Calvinist perspective, because of original sin, one could hardly avoid being the equal to an adulterer except by becoming a saint (James 4: 4).

Penitent's application of the text to his own activity is the next contrast to earlier events. He responds to the text:

Accursed man, that stand'st divorc'd from heaven, Thou wretched unthrift, that hast play'd away Thy eternal portion at a minute's game To please the flesh, hast blotted out thy name, Where were thy nobler meditations busied That they durst trust this body with itself, This natural drunkard that undoes us all And makes our shame apparent in our fall? [IV. i. 3-11] In subject matter, this does not differ markedly from Brothel's earlier selfcondemnation-" And in myself soothe up adulterous motions,/ And such an appetite that I know damns me" (I. i. 94-95). But there is a difference of theological depth, which originates from a personal consideration of texts. 
From Ignatius Loyola's Spiritual Exercises and Parsons' Resolution to Pilgrim's Progress, it is a commonplace of devotional works that the reader must appropriate the text by his meditation on and adaptation to its demands.

Though Penitent quotes only one line of text, his application of the text includes references to several theological concepts; these, in turn, suggest a sophistication of knowledge which would more likely come to a reader. His first application, of course, is to see himself as the "accursed man that stand'st divorc'd from heaven" (3). Then rebuking himself using the thirdperson voice, Penitent accuses, "Thou wretched unthrift ... hast blotted out thy name" $(4,6)$. This echoes Revelation 3: 5, where God promises anyone who perseveres in faith, "I will not blot out his name out of the book of life." Another reminder of a Biblical text occurs when "this natural drunkard [the body] ... makes our shame apparent in our fall" $(9,10)$. Genesis 2: 5 indicates that in their prelapsarian state, Adam and Eve were naked, but not ashamed. After the Fall, "the eyes of them both were opened, and they knew that they were naked" (Genesis 3: 7), and therefore, they hid themselves from God. In these few lines, Penitent confesses his participation in original sin from the perspective of a well-read amateur theologian.

The former lack of occupation for his "nobler meditations" suggests a previous inattention to the lessons of texts, as is evident in his earlier determination to commit adultery despite the possible consequence of 
damnation. However, as a reader and interpreter of texts and self, Penitent most strongly contrasts with Harebrain, who is literate, but who also maintains a pre-literate notion of the power of texts. For Harebrain, the presence of Venus and Adonis signifies immoral activity, and the presence of the Resolution signifies virtue. Thus, there is no application to be made in response to texts because the act of reading, or even possessing, texts is itself moral or immoral (but only immoral if it is venereal). Penitent's response to his reading is a repudiation of his previous adultery, but it is also a reversal of the treatment of texts and knowledge thus far in the play.

From the doctrine of original sin, Penitent turns to describing his salvation and repentance:

Then let my blood pay for't, and vex and boil. My soul, I know, would never grieve to th' death The eternal spirit that feeds her with his breath. Nay, I that knew the price of life and sin, What crown is kept for continence, what for lust, The end of man, and glory of that end As endless as the giver, To dote on weakness, slime, corruption, woman! ... Within these three days the next meeting's fix'd; If I meet then hell and my soul be mix'd. My lodging I know constantly, she not knows. Sin's hate is the best gift that sin bestows; rll ne'er embrace her more; never, bear witness, never. [IV. i. 11-18, 25-29]

These lines represent the point of spiritual transformation from Brothel to Once-IIl. Earlier, I noted that conversion includes repentance (the repudiation of one's sinfulness), but it also indicates faith in God for salvation. As noted just above, Penitent has acknowledged his damnation 
all along, even before cuckolding Harebrain. But now, he speaks of the salvation he has from God. Just as soon as damnation is mentioned, it is as quickly relaced by consideration of "The end of man, and glory of that end/ As endless as the giver" (16-17). The "giver" refers to God as the eternal giver of eternal life in heaven, the "glory" of "the end of man."25

A more interesting appropriation of theology occurs in Penitent's statement, "My soul, I know, would never grieve to th' death/ The eternal spirit that feeds her with his breath" (12-13). Middleton's source must be Ephesians 4: 30: "And grieve not the holy Spirit of God, whereby ye are sealed unto the day of redemption." The presence of the Holy Spirit, Paul indicates, preserves or "seals" the Christian in salvation into eternity, and therefore the Christian should not behave contrary to godliness. Middleton introduces a divine pun because, as theological works commonly note, the single Greek word pneuma is used for both "spirit" and "breath." The eternal holy Spirit of God, therefore, feeds Penitent with himself. Penitent affirms both the security of his salvation in its source from God-the claim of a convert, and his determination to cease grieving the Spirit by his activity - the claim of a penitent.

Immediately after Penitent states his intention not to keep his next rendezvous with Mistress Harebrain, the Succubus enters "in her shape" (IV. i. 29.1). Apparently, with some appropriate alteration of costume, the Succubus would have been played by the same actor who played Mistress 
Harebrain. Henning, even as editor of the text, mistakenly credits the Succubus with effecting Penitent's conversion (xiii). Shapiro calls her "a hallucinatory projection of [Penitent's] old lust, now congealed into remorse" (124). And Rowe says, "Penitent Brothel is encouraged to repent by a dreamlike vision of a succubus whom he believes to be Mistress Harebrain" (108). But by now, Penitent has acknowledged his salvation; remorse has been replaced by resolve. After Penitent's reading of the text, and his response to it, the Succubus introduces the third major contrast to the activities preceding the conversion-simply that, whereas Penitent previously submitted to the temptation of sexual incontinence (brothelling), now he resists, and the demonic nature of the sin is revealed. 26

Hallett justifies the presence of the Succubus by referring it to the Renaissance psychology of conversion:

[Middleton] must find some way-some humorous way suitable to broad comedy - of making us see that Penitent's "nobler meditations" have given him what he was previously lacking-strength of will. The primary function of the Succubus, then, is a psychological one; it symbolizes the last effort of Penitent's imagination to overcome his judgment. Far from being the agency which motivates his conversion, the Sucubus represents a renewal of temptation, and when Penitent at the end of the scene succeeds in driving the Succubus away, we know that his will is no longer aligned with his appetite but with his wit, and we are convinced that he will hereafter have the moral strength to overcome "wild passions." [81]

Although Hallett regards the conversion as consistent with Middleton's religious perspective, he still treats the Succubus, like Shapiro and Rowe, as a projection of Penitent's imagination. 
Penitent himself is uncertain of what he is confronting. First, he concludes it is a devil (IV. i. 36), and rather than drawing on his own resources of will, he calls for divine help: "Celestial soldiers guard me" (31), and "Shield me, you ministers of faith and grace" (33). Yet when the Succubus leaves, he questions his servant about whether Mistress Harebrain has left (75-89). When Mistress Harebrain herself states that she was not in Penitent's room (IV. iv), they conclude that it was a devil who tempted him.

Three features of this Succubus fit what were thought to be common characteristics of spirits in Middleton's time. First, spirits could take the forms of different people. In Nashe's Pierce Penniless, the devil tells Pierce about spirits,

Although in their proper essence they are creatures incorporal, yet can they take on them the induments of any living body whatsoever, and transform themselves into all kind of shapes, whereby they may more easily deceive our shallow wits and senses.... Marcus Cherronesius, a wonderful discoverer of devils, writeth that those bodies which they assume are distinguished by no difference of sex, because they are simple, and the discernance of sex belongs to bodies compound.

Second, when the Succubus questions Penitent, "Feel, feel, man; has a devil flesh and bone?" (IV. i. 37), it raises a central debate among theologians on whether evil spirits are palpable. Henning notes that Reginald Scot summarizes the arguments in chapter four of The Discovery of Witchcraft (1584), a main source for Middleton's tragicomedy The Witch.

Third, once Penitent concludes that his visitor was a Succubus, he uses masculine pronouns to refer to it (IV. iv. 42-49). Demons were believed to be essentially masculine, which meant that every sexual act with a spirit was 
sodomitical. (This will be discussed in chapter four.) Penitent's initial confusion about the nature of his visitor accords with the epistemological confusion any encounters with spirits were thought to bring. He claims that devils and whores are "both so like that, in our natural sense,/ I could discern no change nor difference" (IV. iv. 57-58). The "natural sense" can refer both to the senses limited to physical perception, and the limit of spiritual perception for an unredeemed person.

Penitent's resistance of the Succubus, then, might be more properly described as a religious response than a psychological response through the strength of his will. The appeal to the "celestial soldiers" and "ministers of faith and grace" is to spiritual powers Penitent now has access to because of his salvation. In The Two Gates of Salvation, Middleton cites Isaiah 59: 17: "He put on Righteousnes, as an habergeon, and an helmut of salvation upon his head, and hee put on the Garments of vengeance for clothing, and was clad with zeale as a cloake." His annotation "God in Armes, to the delivering of his Church" (H2v) makes of God himself a celestial soldier. The corresponding second gate is Ephesians 6: 14-17:

Stand therefore and your loynes gird about with verity, and having on the Brest-plate of righteousnes; and your feete shod with the preparation of the Gospell of peace, above all, take the shield of faith, wherewith you may quench all the fierie darts of the wicked; And take the Helmet of salvation, and the sword of the spirit which is the word of God.

The annotation here is, "Salvation, which was purchased by Jesus Christ" $(\mathrm{H} 3 \mathrm{r})$. This second gate calls for the personal appropriation of the power 
God exhibits in granting salvation-his "delivering of his Church"-which appropriation is an act of the will.27 But one does not "quench all the fierie darts of the wicked" (including the Succubus) without divine assistance, which point Hallett's emphasis on psychology obscures. Penitent's call for help from the ministers of "faith and grace" emphasizes what, from a Jacobean Calvinist perspective, are gifts from God.

Once Penitent is rid of the Succubus, he hurries over to Mistress Harebrain to question her intentions, believing she was the Succubus. As they conclude that it was indeed a demonic visitation, Penitent exhorts Mistress Harebrain to mend her ways. This introduces the fourth major contrast with events before Penitent's conversion: Whereas previously he feigned the role of a physician to mate with Mistress Harebrain, now as Once-IIl, he becomes a "physician of the soul" - "commonly the appellation of divines who were thought able to delve beneath apparent character and discover the underlying spiritual state" (Stachniewski 228).

Penitent Brothel's imitation medical knowledge in Act III comes from the contemporary Latin jargon for pharmaceuticals and the spice rackcinnamon and mace. His explanation of the types of scabs (itching, sore, running: III. ii. 104-113) leads Inesse to comment, "You physicians are mad gentlemen" (III. ii. 114). If Penitent is implicated in madness as he pretends to be a physician, he becomes a diagnostician of the general madness of the world in IV. iv: 
No marvel then times should so stretch and turn;

None for religion, all for pleasure burn.

Hot zeal into hot lust is now transform'd,

Grace into painting, charity into clothes,

Faith into false hair, and put off as often.

There's nothing but our virtue knows a mean;

He that kept open house now keeps a quean. [59-65]

The confusion of illusion and reality, which has been identified as the madness of the mad world, here appends to religion and transforms it into lust. Because of the pervasiveness of sin, zeal, grace, charity, faith, and virtue become lust, painting, clothes, false hair-all illusory. Take off the illusion of religion, and there is the devil.

Upon concluding that a devil actually took her shape, Mistress Harebrain implores, "What shall become of me? My own thoughts doom me!" (43). Penitent responds,

Be honest; then the devil will ne'er assume thee.

He has no pleasure in that shape to abide

Where these two sisters reign not, lust or pride.

He as much trembles at a constant mind

As looser flesh at him. Be not dismay'd;

Spring souls for joy, his policies are betray'd.

Forgive me, Mistress Harebrain, on whose soul

The guilt hangs double,

My lust and thy enticement; both I challenge,

And therefore of due vengeance it appear'd

To none but me, to whom both sins inher'd. [44-54]

The end of the sinful madness of illusion is to be honest, to have a constant mind, to suppress lust and pride. None of these virtues come from oneself; had not "worthier cogitations bless'd" him (41)-the prior reflections on his sinfulness and salvation-the Succubus would have "possess'd" Penitent (42). David Farley-Hills inexplicably reads Penitent's exhortation and 
confession as an act of pride itself (104), not observing that he is taking full responsibility for leading Mistress Harebrain astray, and asking her forgiveness. So when Penitent concludes by advising Mistress Harebrain to be faithful again to her husband-"Embrace thy husband, and beside him none" (72)-she repents: "I vow it on my knees, with tears true bred,/ No man shall ever wrong my husband's bed" (74-75). 28 Harebrain enters as she says this, and he and Penitent become fast friends.

The Protestant theology which informs Penitent's conversion and Mistress Harebrain's repentance explains as well their activities as lovers in terms of sin and sickness. As penitents, they respond to a conviction of sin and God's grace; thus, contrary to the arguments of Slights and Shapiro, they do not react merely from self-interest. Indeed, Penitent is interested in saving Mistress Harebrain from the results of his sin. But the Penitent plot also concludes with his attending the play at Sir Bounteous' house as Harebrain's guest. The emphasis on theology in this reading of the play reflects its predominance in the language and emblematic action, but this emphasis should not obscure the play's comic elements. The repentances themselves include an attempted seduction, silly rhyming couplets, and the near-discovery of cuckoldry. This is the comedy of grace, Middleton's version of "this magnificent theatre of heaven and earth, ... the wise contemplation of which should have enabled us to know God" (Calvin, Institutes I: 93). 
The comedy of cozenage, to which the comedy of grace is juxtaposed, is situated in its generic tradition by Penitent Brothel's comments on Follywit, in the same text in which he condemns his own inclination to folly:

Here's a mad-brain o'th' first, whose pranks scom to have precedents, to be second to any; ... h'as play'd more tricks than the cards can allow a man, and of the last stamp too; hating imitation, a fellow whose only glory is to be prime of the company....

I tax his youth of common receiv'd riot,

Time's comic flashes, and the fruits of blood. [I. i. 83-87, 92-93]

Both Slights (87) and William R. Dynes define the trickster of city comedy as "a conflation of the dolosus serous, the crafty servant of Roman New Comedy, and the Vice of the English morality play" (366); Slights adds the adulescens of New Comedy to the type. By describing Follywit's activities as "time's comic flashes," Middleton both invokes and critiques the comedy tradition of the trickster: Follywit descends from comic forebears established in time as a tradition; however, as "flashes," his activities have no permanent (or eternal) worth. Of course, "time" here also refers to Follywit's youthfulness, but in trying to surpass all predecessors "to be prime of the company" in "pranks" and "tricks ... of the last stamp," Follywit's activities are paradoxically situated in the tradition of comic cozenage. The very occurrence of youthful folly is, against itself, traditional, as "common receiv'd riot." The juxtaposition of comic genres of grace and cozenage is not complete until Mistress Harebrain repents, but Middleton's evaluation of the comedy of cozenage, which Rowe reads as an anti-comic attack of New Comedy, begins in Penitent Brothel's first speech. 
However much Middleton patterns his drama by the conventions of New Comedy, he critiques its ethos much as Calvin has done, and from the same theological perspective. Earlier, we noted the aphorisms Follywit and Sir Bounteous throw back and forth about the reciprocal nature of justice. Follywit claims, "For craft recoils in the end, like an overcharg'd musket, and maims the very hand that puts fire to't" (III. ii. 10-12); Sir Bounteous moralizes, "Who lives by cunning, mark it, his fate's cast;/ When he has gull'd all, then is himself the last" (V. ii. 271-272). The principle echoes the Biblical claim that we reap what we sow (Galatians 6: 7).

While religious comment is not prevalent in the Follywit plot, its very subordination is remarked in Eiblical terms. As Sir Bounteous is showing Lord Owemuch (Follywit in disguise) his house, he comments on the scene woven into his bed curtains:

The curtains indeed were wrought in Venice, with the story of the prodigal child in silk and gold; only the swine are left out, my lord, for spoiling the curtains.

[II. ii. 5-7]

By leaving out the swine, Sir Bounteous omits the moral import of the parable; not only does prodigality have no consequences, but Sir Bounteous' setting of the parable in silk and gold positively glorifies it. His resistance to the concept of divine judgment is further notable when he ceases meditating on the seven-foot hole to consider his possible fertility. Thus, as inevitably as Harebrain is cuckolded, Sir Bounteous is victimized by his prodigal grandson. Sir Bounteous and Follywit would like to behave as if they lived in a purely secular world, and critics have read the play's world as 
a secular world, but their concept of secularism is only meaningful by contrast to the religious perspective it purports to dismiss. Secularism is a construct, such a construct as Sir Bounteous creates with his revisionist curtains.

What is Middleton's lesson to "my masters"? Arthur Marotti has claimed, "The members of [the] audience are forced to ... feel that the epistemological obscurity which envelops the characters ... affects them also" (106); this is their participation in the madness of the mad world. But, contrary to the readings of Ayers, Wigler, Rowe, and others, Middleton offers alternatives he treats as real, of Brothel or Once-Ill, the latter being able to penetrate epistemological obscurity to spiritual truth. It was in 1975 that Hallett first regretted "that so few critics are willing to admit that in drawing Penitent Brothel Middleton has attempted to depict the way out of the vicious circle of deceit and illusion" (63). Since then, Middleton criticism has included his religious perspectives, but not in most of the criticism of $A$ Mad World, My Masters. The repentances are what keep Middleton's mad world from being a wholly closed, secular cosmos. The deus ex machina character of the repentances and the appearance of the succubus are intrusions, yes, but intrusions are characteristic of God's grace in Calvinist theology. It is from outside the mad world, from where God gives his grace, that the standards exist for calling the world mad. Middleton locates those standards in his faith. 
III. "That he might read his actions i'th' event?": The Patterns of Repentance

Dating for The Widow places it ten years after A Mad World, in 1616. With as little attention as the play receives, the one common comment on it is that Francisco's repentance resembles Penitent's. Robert Levine, an editor of The Widow, observes that both characters have appointments for a rendezvous, both encounter what they believe are supernatural agents, both reflect upon the eternal consequences of their sinful plans, and both conclude that a guilty conscience undermines courage (lii). ${ }^{29}$ Hallett compares Penitent's ruminations on the Resolution to Francisco's meditations, in which he "reads" the "ghost" before him:

[H]ow blest were man, Might he but have his end appear still to him, That he might read his actions i'th' event?

'Twould make him write true, though he never meant. [III. ii. 116-119] Hallett concludes, "Middleton has made consideration of the 'end of man' the catalyst that drives the adulterous lover to repentance in The Widow as well as in A Mad World" (79-80). Both Friedenreich (14) and David Holmes (142) make passing observations of the similarity between Penitent's Succubus and Francisco's "ghost," though in their comparisons, they conclude that the Succubus effected Penitent's conversion.

Francisco seems to repent as a Christian-from the perspective of one who believes that he is already saved, instead of converting to Christianity. Thus he asks, "And what do's fond man venture all these ills for,/ That may so sweetly rest in honest peace?" (III. ii. 107-108). Francisco is himself the 
fond man he questions, and he seems to have access already to honest peace, a sign that he is saved. He may keep that peace if he remains chaste.

One significant difference between Francisco and Penitent is that Francisco is a virgin. He tells Ricardo, "I never yet lov'd but one Woman" (I. ii. 52). That one woman is Philippa, Justice Brandino's wife, who, having failed to mate with Francisco, informs Ansaldo, "For on my conscience he has his Maidenhead yet" (V. i. 283). This is intended to be believed because "Ansaldo" turns out to be Martia in male disguise, and she is finding out Francisco's worthiness to become her husband. Francisco's chastity is contrasted to Ricardo's profligacy (I. ii. 52-56), and the play's audience may easily conclude that Francisco acts from a different basis of spiritual understanding than does Ricardo, the rakish youth. 30

Comparisons of Francisco and Penitent have focused on the similarities between Francisco's reaction to his "ghost" and Penitent's reaction to the Succubus. What Francisco sees from a distance is "Ansaldo in his shirt" (III. ii. 54.1). Ansaldo is in his shirt because he has just escaped robbery in the nearby forest. What state of exposure is implied by his being only in his shirt is unclear, but so far, Ansaldo has not yet been revealed to be Martia. Thus, the audience would have to conclude that Ansaldo is male, without making the later revelation that "he" is Martia completely improbable.

This sexually ambiguous figure in the night makes Francisco think he has seen a spirit: "Life, what should that be? a prodigious thing/ Stands just 
as I should enter, in that shape too,/ Which alwaies appears terrible" (III. ii. 90-92). Sexual ambiguity, as we have seen with Penitent's male references to the Succubus, is consistently demonized in Middleton's culture. Having been questioned, the signifier may now signify anything that teaches Francisco the same basic lesson. The spirit might be of his deceased father, who was a friend to Justice Brandino: "Why may ' $t$ not be the spirit of my Father/ That lov'd this man [Brandino] so well, whom I make haste/ Now to abuse?" (III. ii. 102-104). The spirit may be "A wicked mans own shadow [which] has distracted him" (98). Or it may be of friends or enemies: "Whose check so ere thou art, Fathers, or Friends,/ Or Enemies, I thank thee, peace requite thee" (120-121). Penitent, similarly, is also uncertain at first about whether or not the Succubus is actually Mistress Harebrain.

However, the uncertainty itself has value if it causes one to reflect upon his or her activities:

What ere it be, it is made strong against me By my ill purpose. For 'tis mans own sin

That puts on armor upon all his evils, And gives them strength to strike him: were it less Then what it is, my guilt would make it serve. Because "Ansaldo" first appears in Act III, scene $i$, the audience knows that he is not a spirit. Thus, Francisco's "ghost" is closer to being a delusion than Penitent's Succubus. But the delusion is caused by his sinful intent, so it still reveals an underlying spiritual reality-that Francisco has strayed.

Francisco's ghost links what can be treated separately in the repentances of other plays-the confrontation with one's sinfulness and the revelation 
of its demonic or monstrous character. Penitent confronts his sinfulness while reading, and he later recognizes the demonic character of his sin with the appearance of the Succubus. In Michaelmas Term, Richard Easy does not recognize his wrongdoing until he has lost everything, but its demonic nature is reified from the first act in the characters of Shortyard and Falselight, Quomodo's spirits (discussed in chapter four).

While The Widow, A Mad World, and Michaelmas Term offer the representation of a demon, the revelation of the demonic character of sin need not be so literal. In The Second Maiden's Tragedy, the Lady connects her father Helvetius' sin to the demonic when she questions his nature:

Can you assure me, sir, Whether my father spake this, or some spirit Of evil-wishing that has for a time

Hired his voice of him, to beguile me that way?

[II. i. 101-104] Helvetius himself does not recognize his sinfulness until Govianus wounds him with a gunshot. In $A$ Chaste Maid, a similar wound by a sword reminds Sir Walter of his mortality, leading to his repentance. When the Allwits hold his bastard children over his sickbed, he treats them as a sign of his guilt, which becomes demonic: "Still my adulterous guilt hovers aloft/ And with her black wings beats down all my prayers/ Ere they be half way up" (V. i. 77-79). And in A Yorkshire Tragedy, the Husband considers himself exorcised during his repentance:

[N]ow glides the devil from me, Departs at every joint, heaves up my nails.

$O$, catch him new torments that were ne'er invented; 
Bind him one thousand more, you blessed angels, In that pit bottomless. [X. 18-22]

The representation of sin as monstrous, rather than as demonic, occurs in two works in which the person who reminds the penitent of his sin is not herself responsible for the sin. In The Roaring Girl, Sir Alexander regards Moll Cutpurse as monstrous, but her monstrosity signifies his sinfulness; when he repents, she ceases to be monstrous (discussed in chapter four). In No Wit, No Help Like a Woman's, the monster of Philip's sin is evident in his wife Grace, whom he comes to think is also his sister: "Oh, to what mountain shall I take my flight,/ To hide the monster of my sin from my sight" (IV. i. 247-248). Though Philip sinned in marrying Grace rather than rescuing his mother from a kidnapping, the charge of incest is later cleared when his true sister is revealed, and the monstrousness evaporates in the affirmation of his marriage.

The awareness of sinfulness and its demonic nature can lead a character to consider his or her eternal destiny. Penitent laments playing away his "eternal portion at a minute's game,/ To please the flesh" (IV. i. 5-6). Francisco fears that if he succeeds in cuckolding Brandino, "For that which being obtaind, is as he was/ To his own sence, but remov'd neerer still/ To death eternall" (III. ii. 109-111). In A Chaste Maid, Sir Walter charges Allwit,

None knew the dear account my soul stood charg'd with So well as thou, yet like hell's flattering angel Would'st never tell me on't, let'st me go on And join with death in sleep. [V. i. 28-31] 
And in A Game at Chess, the White Queen's Pawn rejects the Black Bishop's Pawn's temptation to commit adultery (and by implication, apostacy): "So hot-burning/ The syliables of sin fly from his lips,/ As if the letter came new cast from hell" (V. ii. 42-44).

The transformations of the penitents is usually stated in terms of one of two Biblical metaphors, from sickness to health, or from darkness to light. I have already discussed the sickness/health metaphor in Penitent's conversion, The Two Gates of Salvation, and The Revenger's Tragedy (see endnotes 13 and 14). In Michaelmas Term, Richard Easy exults, "My joys exceed;/ Man is ne'er healthful till his follies bleed" (V. i. 14-15). And in The Second Maiden's Tragedy, when shot by Govianus, Helvetius regards his wound as the useful probing of a surgeon:

This was well searched indeed, and without favouring. Blessing reward thee! Such a wound as mine Did need a pitiless surgeon. Smart on, soul; Thou't feel the less hereafter! [II. i. 154-157]

The trope of salvation as a movement from darkness to light, or as a transformation from blindness to sight, is offered throughout the Bible: John 3: 19-21; II Corinthians 4: 3-4; Ephesians 5: 8; I Peter 2: 9. In The Two Gates of Salvation, Middleton cites Isaiah 35: 5-6: "The eyes of the blind shall be lightned, and the eares of the deafe be opened. Then shall the lame man leape, as an Hart, and the dumb mans tongue shall sing: for in the wildernesse shall waters breake forth, and Rivers in the desart" (D4v). Although this is a prophecy of physical healing, Middleton annotates the 
text: "In the wildernes, that is, in barren hearts and ignorant." This suggests that these ailments afflict the soul, and he reads this text to agree with the blindness/sight metaphor. In the civic pageant The Triumphs of Truth, darkness and blindness are explicitly equated with Error and Envy, "Error's minister, that still sought to blind thee" (240). But London's new mayor is "A son of honour, in whose soul burns clear/ The sacred lights of divine fear and knowledge" (236). Likewise, remarking on his complexion, the King of the Moors asserts, "However darkness dwells upon my face,/ Truth in my soul sets up the light of grace" (248).

The same trope appears throughout the drama. Commenting on the Succubus to Mistress Harebrain, Penitent observes the obscurity that covered his former state:

What knows the lecher when he clips his whore Whether it be the devil his parts adore? They're both so like that, in our natural sense, I could discern no change nor difference. [IV. iv. 55-58]

Earlier, I noted that Francisco considers the person blessed who has the insight to read his own actions-who has "his end appear still to him" (III. ii. 116-118). For Helvetius, once his sins are revealed, he calls them monstrous: "With what fair faces/ My sins would look on me!-but now truth shows 'em,/ How loathsome and how monstrous are their forms" (II. i. 159-161). And in The Roaring Girl, Sir Alexander rejoices for his new insight: "How short my sleep of sorrow seems now to me,/ To this eternity of boundless comforts" (V. ii. 175-176). When he asks for forgiveness from 
his new daughter-in-law, Mary Fitzallard, the blindness/sight metaphor is prominent:

Forgive me, worthy gentlewoman, 'twas my blindness:

When I rejected thee, I saw thee not;

Sorrow and wilful rashness grew like films

Over the eyes of judgement, now so clear

I see the brightness of thy worth appear.

[V. ii. 191-195]

This new health or sight is generally treated as God's gift, the result of divine grace to the penitent or convert. This is very much a Calvinist emphasis, that the elect are given salvation without regard to their merit. Middleton usually employs a metonymy for God, probably in deference to current censorship practices. For Penitent, salvation comes from "the eternal spirit" that feeds his soul with his breath (IV. i. 14). After his repentance, Francisco exhorts Philippa, "What means [heaven] sends to help you, think and mend,/ You'r as much bound as we, to praise that frend" (V. i. 508-509). Thinking on the help he has received from Quomodo's ex-wife, Richard Easy claims in Michaelmas Term, "The angels have provided for me" (IV. iv. 79). For Gratiana, in The Revenger's Tragedy, her repentance is itself a divine gift: "Make my tears salt enough to taste of grace!/ To weep is to our sex naturally given;/ But to weep truly, that's a gift from heaven" (IV. iv. 53-55). The Colonel in A Fair Quarrel treats his reconciliation with Captain Ager and their union into one family as a "blessed alliance sacred heaven/ Has placed my kinsman, and given him his ends" (V. i. 429-430). Other claims for the presence of divine grace appear in The Roaring Girl (V. ii. 173-174), The Witch (V. iii. 55-62), and A Game at Chess (V. ii. 68-79). 
Francisco's exhortation to Philippa to mend her ways is joined by Martia's assertion, "Heav'n will not let you sin, and you'ld be carefull" (V. i. 507). Their concern for Philippa's virtue parallels Penitent's concern for Mistress Harebrain's spiritual well-being after his conversion. Theodorus Witgood exhibits a similar concern for the Courtesan's well-being in $A$ Trick to Catch the Old One, a play in which most of the action occurs after they have first repented. They have a second, public repentance in the conclusion, but as a restatement of the resolve with which they begin the play. This form of action, in which a penitent shows concern for another's well-being, may be considered a type of witness or hortatory effort. A failed effort occurs in Women Beware Women, when the Cardinal urges both the Duke and Bianca to repent, to no avail.

One kind of scene appearing in A Mad World but not in The Widow is the temptation or testing of the penitent. This usually occurs to show the strength of the penitent's new-found spiritual resolve. Penitent's test is, of course, his confrontation with the Succubus (see endnote 26). Gratiana is tested by her daughter Castiza's agreement with Gratiana's earlier proposal to prostitute herself to Lussurioso. Gratiana's response is to try to witness to Castiza: "[1]f there be any spark/ Of heavenly intellectual fire within thee,/ $\mathrm{O}$, let my breath revive it to a flame" (Revenger's Tragedy, IV. iv. 117-119). Castiza soon confesses of her decision, "I did this but to try you" (148).

Helvetius is tested more surely by imprisonment for refusing to procure his daughter for the Tyrant. His losses, however, are no further 
concern to him: "So by imprisonment I sustain great loss:/ Heav'n opens to that man the world keeps close" (Second Maiden's Tragedy, II. iii. 100-101). Sir Walter Whorehound is likewise imprisoned in $A$ Chaste Maid, though his end is often read to suggest the ineffectiveness of his repentance. The similarity between Helvetius and Sir Walter can raise questions of that conclusion, to be discussed in the next section.

This catalogue of similarities in the repentances and conversions reveals the general pattern of repentance in Middleton's drama-a revelation of the character's sinfulness (with references to its demonic nature and the character's eternal destiny), a repudiation of that sinfulness, an acknowledgement of new spiritual health or sight, a further acknowledgement of divine grace, and, in some plays, a hortatory effort and/or a test of the penitent. The claim that Penitent's conversion is paradigmatic is supported by its having all of these features represented in detail. The critical skepticism with which it has been read must itself be questioned by Middleton's propensity, bordering on compulsion, for restaging and reconsidering repentance across genres and time periods of his career. Furthermore, if some ironies append to Penitent's conversion (see endnotes 25 and 28), such ironies are missing in the repentances of Gratiana, Helvetius, Francisco, and White Queen's Pawn; this suggests the basic seriousness of repentance for Middleton.

In chapter one, when I state that Middleton does not write as an evangelist, I mean that to treat his plays as religious tracts would be 
reductionist. Yet, as there is a paradigm for repentance, it is one which he commends to his audience. One further similarity between Penitent and Francisco is their fluctuating use of voice to refer to themselves. Penitent's meditation begins in the third person: "Accursed man, that stand'st divorc'd from heaven"-moves to the second person: "Thou wretched unthrift .../ Where were thy nobler meditations busied?"-goes to the first person plural: "This natural drunkard that undoes us all"-and ends with the first person singular: "My soul, I know, would never grieve ... the eternal spirit" (IV. i. 3, 4, 7, 9, 12-14). Francisco uses the third person singular to refer to "mans own sin/ That puts armor upon all his evils," the "fond man" who "venture[s] all these ills ... [t] hat may so sweetly rest in honest peace," and the "blest" man that "might read his actions i'th'event" (III. ii. 94-95, $107-108,116,118)$. What is specific to these characters also applies generally; they not only speak for themselves, but of the general state of humanity as well. Thus in repentance, general truth becomes personal belief, appropriated, as it were, into the character's inwardness, and blurring the distinction between subjectivity and objectivity. This is, of course, a strategic blurring, no more nor less contestible than the commendation of Calvinist belief in The Faerie Queene (shown as contested but ever victorious), or the commendation of Catholicism in John Ford's plays. Clearly, however, for Middleton, if the audience member "might read his actions i'th'event," he would respond like Francisco and the other penitents: "'Twould make him write true, though he never meant" (III. ii. 119). 
IV. Sir Walter Whorehound's Anti-Tragic Repentance

A Chaste Maid in Cheapside is distinctly focused on setting in place, time, and society. It has multiple references to London streets, landmarks, and neighborhoods-Holborn Bridge, Bridewell and Newgate Prisons, Turnbull and Bucklersbury Streets, the Strand, Blackfriars, the Pissing Conduit, Goldsmith's Hall, several wharves and other places on the Thames, and Cheapside itself. There is more of the city in this city comedy than in any other Middleton play.

The time is the month of March, in the middle of the Lenten season. Several of the play's larger ironies are occasioned by the inherent paradox of Lent-the religious season of restraint, discipline, and sacrifice occurs during the natural season of fertility and profusion. This juxtaposition is at the root of critical controversy over this play. Arthur Marotti, for one, comes squarely on the side of fertility. The priapic Touchwood Senior is "a healthy counterbalance to anti-life activities like fanatical and hypocritical religious asceticism, ruthless social climbing, and the stubborn pursuit of wealth for its sake" ("Fertility" 68). Never mind his cuckolding of Kix which recalls the doomed Allwit-Whorehound relationship.

The social setting is created by the abundance of roles; this may be the most populated of significant Renaissance dramas. The exact number of roles depends on which roles are recurring. Is the man pawning a gold chain in Yellowhammer's shop (I. i. 84, 103) one of the men sneaking contraband meat past the promoters, enforcers of Lenten restrictions (II. ii. 
104-132)? Some actors must have taken two or three roles in 1613; the actor playing Sims the porter would be free to play the parson as well. Yet there are at least forty roles spanning such types as gossips, boatmen, a Welsh whore, nurses, a goldsmith, a Cambridge scholar, a tutor, wives, promoters, gentlemen, a porter, a knight, young children, a parson, puritan women, chambermaids, and certainly not to be forgotten, a chaste maid.

A Chaste Maid in Cheapside, like A Mad World, My Masters, has a thesis in its title. It is to be noted that there is even one chaste maid in Cheapside, a rarity akin to a modest person on Bourbon Street during Mardi Gras. Chastity is against the grain in the society of this play, contested even by the language which acknowledges its presence. Not only is there a chaste maid, oddly enough, but she is also a chased maid, pursued by two suitors whose own morals originate in the codpiece. Furthermore, the chaste maid is named Moll, which name Allwit uses as a general term for whores (II. ii. 70). Another character elsewhere observes that there are "more whores of that name than any ten other" (Roaring Girl II. ii. 155).

By locating $A$ Chaste Maid in the everyday setting of London life, Middleton makes its extremes seem commonplace. Certainly the characters scarcely regard their own activities as unusual. Allwit shows an ordinary, middle-class contentment with his financial security:

I walk out in a morning, come to breakfast, Find excellent cheer, a good fire in winter; Look in my coal house about midsummer eve, That's full, five or six chaldron, new laid up; Look in my back yard I shall find a steeple 
Made up with Kentish faggots, which o'erlooks The waterhouse and the windmills; I say nothing, But smile and pin the door. [I. ii. 22-29]

If this represents the aspirations of the middle-class Jacobean Londoner, Allwit is anxious (IV. i. 192-264) $)^{31}$ to attain these comforts by pimping his wife to Sir Walter Whorehound, wholly abrogating the responsibilities and privileges of being a husband and father. Allwit uses all of his wit to remain a wittol. His paean to his comforts, therefore, is bracketed by praise to Sir Walter for his provision and care of Allwit's family, parodying Psalm 23:

The founder's come to town; I am like a man Finding a table furnish'd to his hand, As mine is still to me, prays for the founder: "Bless the right worshipful, the good founder's life." [11-14] This soliloquy ends with Allwit rhapsodizing, "La dildo, dildo la dildo, la dildo dildo de dildo" (56).

Other major characters are equally mercenary for their comforts. The Yellowhammers calculate the financial and social advantages to themselves for their children's marriages; if Sir Walter, their choice for Moll's fiancé, is profligate, "No matter, so the whore he keeps be wholesome;/ My daughter takes no hurt then, so let them wed" (IV. i. 273-274). So set is Mistress Yellowhammer on this match that she grabs Moll off a boat midstream in the Thames and drags her by the hair to the shore (IV. iii). ${ }^{32}$

The Kixes both abuse and console each other for their childlessness; yet their motivation for wanting a child is financial first of all. Lady Kix reminds her husband, "'Tis our dry barrenness puffs up Sir Walter;/ None 
gets by your not-getting, but that knight" (II. i. 160-161). The nature of the relationship between the Kixes and Sir Walter is never made clear, but if they get a child, he loses his fortune to them. What they accept as a fertility treatment is Touchwood Sr's own sexual capability (III. iii); Kix seems unaware at this point that he is being cuckolded. However, at the end of the play, Kix's arrangement with Touchwood replicates Allwit's just-ended association with Sir Walter: "I have purse, and bed, and board for you;/ Be not afraid to go to your business roundly;/ Get children, and I'll keep them" (V. iv. 80-82). In Cheapside, any man can adjust to his cuckolding if it is financially profitable.

The Touchwood brothers have seemed to some critics to be the moral spokesmen for the play. Touchwood Jr, the putative hero and Moll's preferred beloved, is willing to wait until marriage to consummate their sexual relationship, but his lust drives their efforts. He instructs Moll, "Turn not to me till thou may'st lawfully, it but whets my stomach, which is too sharp set already" (I. i. 138-139). Middleton shows no reticence about the fulfillment of sexual desire as a motivation for marriage; this motivation is validated in Sebastian's engagement with Mary Fitzallard in The Roaring Girl. But the purity of Touchwood Jr's wish to stay within legal bounds ("till thou mayst lawfully") is belied by his active promotion of his senior brother's arrangement with the Kixes (III. iii. 1-13). If that is successful, Touchwood Jr will rise above the bankrupt Sir Walter as a desirable partner for Moll. Sebastian has the advantage of divine ordination for his wedding 
plan (I. i. 78-80), but such an imprimatur is conspicuously absent for the Touchwood Jr-Moll relationship. Their success depends upon adapting to the norms of their society.

Touchwood Sr makes most of the moral observations in this play. He is tenderly concerned for his wife's well-being at the beginning of Act II. He promotes his brother's marriage by hiring the watermen (IV. ii) and by gaining support for the union during the lovers' feigned funeral (V. iv). He also pities the Kixes for their quarrels. But Touchwood $\mathrm{Sr}$ is no selfless altruist. He ceases sexual relations with his wife to keep from having more children and thus going bankrupt. Meanwhile, he is whoring around the countryside, and his potency is such that his every encounter results in a pregnancy. Mirroring the financial danger within his own family, Touchwood Sr's potency also poses a threat to the nation's economy. "Fatal finger" in this passage is a euphemism for his phallus:

I have such a fatal finger in such business

I must forth with't, chiefly for country wenches,

For every harvest I shall hinder hay-making;

I had no less than seven lay in last Progress,

Within three weeks of one another's time.

[II. i. 59-63]

This planned roll through all of England's hay is put aside for the more profitable arrangement with the Kixes, netting $£ 400$ per pregnancy. Thus, any moral import in Touchwood Sr's comments should be regarded as typical of Middleton's assignment of moralisms to immoral characters, such as Penitent Brothel's condemnation of Follywit and himself in Act I of $A$ Mad World. 
The follies of these and other characters reveal the depths of human depravity; yet it is at least conceivable that someone in the London locale would pimp his wife, force his daughter into an undesirable marriage, or break Lenten restrictions on meat consumption. Touchwood Sr's magical potency, however, exposes the fictionality of Middleton's Cheapside; no one is quite so prolific. For all of its local references, therefore, Middleton does not present an eyewitness recreation of Cheapside, but a satiric exposure of its sinful extremes. The much-praised realism of this play is mimetic, not the documentary representation of Jacobean London Middleton tempts his audience into believing it is.

David Bergeron examines the fictionality of $A$ Chaste Maid in Cheapside by contrasting it to the The Triumphs of Truth, both written in 1613. The civic pageant was performed in the streets of London, with scenes occuring in Cheapside:

The pageant drama assumes its theatrical reality in Cheapside where most of the show takes place, citizens standing there to watch the mayor and his retinue pass through its streets. That part of the city is thus immediately and physically real. But Middleton also creates a fictional world of London. In the comedy the fiction creates the reality of London, and in the pageant the real world gives rise to the allegorical fiction. [135]

Moreover, with these two texts, Middleton has created "an impressive Renaissance gold medal with one side depicting a large foreground of sin and corruption (the comedy) and the obverse with an equally large foreground of virtue (the pageant)" (133). With Truth and Error contesting for the allegiance of the new Lord Mayor in the streets of London, The 
Triumphs of Truth situates its Augustinian conflict in the present moment, more so than in such moralities as Everyman or Mankind in which time and place disappear in generalization or abstraction.

The mayor's choice, as dramatized by Middleton, is presently consequential, not only for his personal salvation (which is never in doubt), but also for the future of London (where the audience stands). By extension, the mayor's decision could also affect the empire and, with the appearance of the Moors, the whole world. Other moralities, such as Magnyfycence, King Johan, and Ane Satire of the Thrie Estaitis, are equally political, but only insofar as power centers in royalty and nobility. With the annual selection of the Lord Mayor made from the leaders of the merchant and trade guilds, the moral and religious choices of closer-to-average citizens in Middleton's pageants rise in national significance. Such citizens in the play include Yellowhammer, a member of the Goldsmith's Hall. The mayor to whom the pageant is dedicated was a Grocer. 33

Bergeron's essay appears in the same collection in which Kenneth Friedenreich argues for a moral field in Middleton's works; for Bergeron, a moral landscape is clear when the pageant and play are read together. The problem with much of the criticism of $A$ Chaste Maid in Cheapside is that the play is read as if Middleton wrote no other religious text. So if, as Bergeron claims, the play presents a large foreground of sin flourishing, a critic not sensitive to the religious perspectives of Middleton and his first 
audiences is likely to conclude that Middleton favors attitudes which he is, in fact, exposing.

Robert I. Williams, for example, usefully draws attention to Machiavelli's play The Mandragola as a probable source for Touchwood Sr's relationship with the Kixes. In The Mandragola, Callimaco offers his services to cure Messer Nicia and his wife Lucrezia of their sterility. Williams' conclusion, drawn from Touchwood Sr's similiarities to Callimaco, is,

[A] good heart alone will not guarantee survival in the vicious environment of middle-class London. Wit is needed, cleverness without encumbrance of moral sensibility is needed, and romantic values like goodness, bravery, and sensitivity will not by themselves prevail over money lust. [394]

From what we have already seen, Touchwood Sr's "good heart" is questionable. The fact that he is Machiavellian, then, would imply criticism from the antipathetic Calvinist perspective, if one acknowledges the existence of that perspective.

Read in isolation from Middleton's other texts, $A$ Chaste Maid can certainly look like it is opposed to spiritual values. That is the interpretation Rowe gives: "Christian values have no place in the play-society" (138). Every Christian expression is in some way parodied, perverted, or suppressed, as we have seen in Allwit's parody of Psalm 23 and the efforts to feast during Lent. In Act II, scene ii, the Country Wench passes off her bastard infant to the promoters in a basket filled with mutton, parodying the Christ child as the Lamb of God. The christening party (III. ii) for Mistress 
Allwit's daughter (fathered by Sir Walter) degenerates into gluttony and drunkenness. The First Puritan, Mistress Underman, informs Mistress Allwit that her daughter has been "kursen'd" (III. ii. 3), punning on "cursed," and Rowe notes this as "an episode which undoubtedly does much more to damn Whorehound's child than to save it" (137). Sir Walter's own repentance is opposed by the Allwits, who evict him when they decide he is too far gone to assist them further. All of these moments can suggest, and have been taken to suggest, the inefficacy of religious values in Middleton's Cheapside, and therefore for Middleton himself.

But if the characters are blind to the spiritual dimensions of their world, the nature of this blindness itself is the point of these incidents. When the Wench passes her child to the promoters, that act is naturalistic in the view from Cheapside; no one there would think to suggest that a child hidden in mutton reminds him of the agnus dei. Instead, the promoters curse their sorry luck and plot to dispense with this new inconvenience. Any consideration of the relevance of the agnus dei to this scene begins outside of the verbal language of the scene itself.

What Middleton depends upon is the attentiveness of his readers and audience to the religious symbolic vocabulary, or emblem, encoded into the performance itself. Debora Shuger's assessment of Jacobean culture-that "Religion during this period supplies the primary language of analysis" (6) - suggests Middleton's first audiences would have probably assumed the allusion to the agnus dei. Modern readers and critics have the Wakefield 
Second Shepherds' Play to remind them of the allusion. An Augustinian reading of this parody would suggest that however blind to spiritual dimensions the inhabitants of Cheapside may be, the locale is still suffused with references to the neglected reality. An alternative, which Rowe offers, is that the parody is blasphemy: "Like the drama's imitations of Lenten practices and the ritual of baptism, the play's mock nativity debases the original" (138-139).

The portrayal of the Puritans in the christening party would seem to support Rowe's interpretation. Like Harebrain, these Puritans show great concern for exterior forms. Mistress Underman (First Puritan) informs Mistress Allwit that her infant daughter was "verily well kursen'd, i'the right way,/ Without idolatry or superstition,/ After the pure manner of Amsterdam" (III. ii. 3-5). Second Puritan objects to the gift of an apostle spoon because its gilt color suggests Judas Iscariot's red hair (49-51).34

Yet their purity of forms is undercut by their bawdy punning, gluttony, and drunkenness. The characters themselves may be unaware of their own innuendo, as when Mistress Underman declares, "Children are blessings, if they be got with zeal,/ By the brethren, as I have five at home" (III. ii. 36-37). But they are anxious to put a religious spin on any action to justify themselves. When Mistress Underman topples from her drink, she moralizes, "Tis but the common affliction of the faithful,/ We must embrace our falls" (180-181). 
Margot Heinemann, who describes Middleton as a Puritan, admits that the Puritans in this play are hypocrites, but she finds the criticism softened somewhat by the worse presence of their host, Allwit (84). Her claim that for Middleton "Puritan" usually means "sectary" (77) may also apply here. Grumbling about his guest's appetite, Allwit would like for Mistress Underman to "Go take a nap with some of the brethren, go,/ And rise up a well-edified, boldified sister!" (197-198). This recalls the practices of the Family of Love, whom King James called Puritans, rather than the broader group of reform-minded churchgoers. By the Family's doctrine, the AllwitSir Walter arrangement could even be considered acceptable, since the sectarians believed their sanctification extended to any illicit relationship.

Whether or not Cheapside's Puritans are part of that sect, they offer no hope for reform, neither on the personal level nor for the play society. Their failure to discern the spiritual corruption around them extends even to the physical evidence. Along with the rest of the christening party, they miss the fact that Allwit is not the father of the infant:

[Second Gossip:] How say you now, Gossip, is't not a chopping girl, so like the father? Third Gossip: As if it had been spit out of his mouth, Eyed, nos'd and brow'd as like a girl can be, Only, indeed, it has the mother's mouth. [8-12]

The Third Gossip later adds, "I would care not what clown my husband were too, so I had such fine children" (32-33). Of course, Allwit had no genetic input in the child's conception, so the guests can not be identifying anything more than superficial similarities on the physical level. Likewise, the 
christening itself, though done without idolatry and superstition, bears only a superficial relationship to the proper spiritual realities of that ritual.

Although $A$ Chaste Maid is too sardonic to be a tragicomedy, yet with its foreground of sin and its corresponding absence of any efficacious offering of grace (up through Act IV), the play heads towards a tragic resolution. Evil is, in fact, more victorious in this play than in A Yorkshire Tragedy, The Revenger's Tragedy, and The Second Maiden's Tragedy. In these tragedies, the repentances of Husband, Gratiana, and Helvetius, and the fall of the Tyrant to Govianus all show the survival or the triumph of Christian grace over the stratagems of the villains. Grace does appear in $A$ Chaste Maid as the way out of its sin-glutted society, but though grace is free, it evidently appears rarely, and its acceptance can lead to mortification.

The tragic tendency has been noted more by the play's directors than by its other critics. Alan Brissenden reports the effect of Moll's song (V. ii.

41-48) at a 1966 performance:

Similarly, the moment of Moll's apparent death emphasizes by contrast the callousness of her parents. We may laugh at Maudlin's ' $O$, I could die with music' (V. ii. 50) as Moll sings her last strain, but the laughter has an undercurrent of disgust. Here Middleton is again using an ironic technique to make his point. (I am told that Moll's song created a moment of genuine pathos, making the comedy all the blacker, when the play was performed in London in 1966. Quite unexpected, this effect was, as the producer William Gaskill said, one of those things that 'just happen' in the theater.) [xo]

David Richman, who directed the play in 1978, discusses at length the problem of maintaining a consistent comic tone in the first two scenes of Act $V$, the scene of Whorehound's repentance and Moll's apparent death: 
If I interpreted these scenes as truly tragic, I would risk serious tonal discord in an essentially comic production. But I would not dismiss the idea that Middleton might have intended such discord in his play, devising in Fletcherian fashion a grim sequence to precede and contrast with the surprise of his comic ending.

[83]

Richman's solution was to give away the conspiracy of Moll's feigning death with stifled giggles and stolen kisses; yet this technique has "no primary textual indication" (83). He claims his staging maintains a consistent satiric tone, but he also notes that his is just one possible solution. ${ }^{35}$

Against all earlier indications, it is Sir Walter Whorehound who finally recognizes the tragic trajectory of life in Cheapside. His only moral comment before his repentance is to say of Allwit, "When man turns base, out goes his soul's pure flame,/ The fat of ease o'erthrows the eyes of shame" (II. ii. 40-41). Sir Walter recognizes Allwit's baseness as his accommodating his own cuckolding to maintain his ease. But in spite of calling Allwit a slave (II. ii. 39), Sir Walter misses the fact that Allwit, for all his seeming acquiescence, actually dominates their arrangement. He is a slothful aggressor, interested in the status quo and diligent to keep it.

Furthermore, Sir Walter fails to acknowledge his own baseness, and thus the extinguishing of his own pure flame. Of all of Middleton's penitents, he best exemplifies the unpredictable nature of grace in Calvinist theology. Penitent's conversion, albeit a surprise, has a few clues, including his name itself. In A Chaste Maid, a repentance of Touchwood Sr would accord with his moralizing speeches, or a repentance of either 
Yellowhammer parent would permit a romantic ending. But there are no signs that Sir Walter's repentance is coming, and even though it opens the way for Touchwood Jr to marry Moll, Touchwood is then presumed to be dead. Sir Walter's election to Protestant sainthood occurs without merit on his own part, as Calvin asserts is true for all penitents. Divine grace, it turns out, is the only way out of Cheapside's cosmos of sin-the "world" of I John 2: 16, "For all that is in the world, the lust of the flesh, and the lust of the eyes, and the pride of life, is not of the Father, but is of the world."

The change towards tragedy begins in Act IV, scene iii, when Maudline Yellowhammer drags Moll through the Thames, again thwarting her nuptials, and setting up the circumstances in which her death would seem plausible.36 Then Sir Walter and Touchwood Jr duel for Moll, wounding each other. To accord with the next scenes, the wounds should seem to be serious, potentially fatal. Sir Walter then withdraws from the fight, saying he has "certain things to think on/ Before I dare go further" (77-78).

This brush with his own mortality affords Sir Walter his first opportunity to consider his eternity. His damnation is inextricably tied to his relationship with the Allwits, so even while acknowledging his own sinfulness, he blames them for their cynical determination to advance his sin for their own purposes:

Thou know'st me to be wicked, for thy baseness

Kept the eyes open still on all my sins;

None knew the dear account my soul stood charg'd with

So well as thou, yet like hell's flattering angel 
Would'st never tell me on't, let'st me go on

And join with death in sleep: that if I had not wak'd

Now by chance, even by a stranger's pity,

I had everlastingly slept out all hope

Of grace and mercy. [V. i. 26-34]

Sir Walter's repentance is expressed in the same darkness/sight metaphors that also appear in the repentances of Helvetius, Francisco, and Penitent. He does not foist his responsibility onto the Allwits, but following them is equivalent to following the devil, "hell's flattering angel" (29). Paradoxially, Allwit seems to see before Sir Walter himself does, with "the eyes open still on all my sins" (27). But without the "soul's pure flame" (II. ii. 40), Allwit's blindness is to shame, such as Sir Walter now experiences, and therefore he cannot comprehend the spiritual conviction behind this repentance.

Although Touchwood Jr was intent on killing him ("I'll follow thee to death, but ha't out" [IV. ii. 80]), Sir Walter attributes his wound to "a stranger's pity" which awakens him to grace and mercy (V. i. 32-34). Because the stranger cannot be Touchwood Jr, Sir Walter's awakening must come from God himself, the stranger to his spiritually blind self. His awakening leads directly to his repentance:

Let me forever hide my cursed face From sight of those that darkens all my hopes And stands between me and the sight of heaven. Who sees me now, he too and those so near me, May rightly say, I am o'er-grown with sin.

$O$ how my offences wrestle with my repentance!

...

My taste grows bitter; the round world, all gall now;

Her pleasing pleasures now hath poison'd me, Which I exchang'd my soul for.

[V. i. 70-75, 81-83] 
Of those who see Sir Walter now overgrown with sin (73-74), "he too," according to Loughrey and Taylor's annotation, refers to God, represented by "heaven" (72), as in The Widow. Sir Walter's confession, therefore, captures the divine perspective-what God sees. It expresses the attitude the play itself leads the audience to take to Cheapside and the cosmos generally: This "round world," overgrown with sin, is "bitter" and "all gall now" (81). This insight distinguishes Sir Walter from the Puritans at the christening, who are oblivious to the spiritual realities surrounding them. With the Allwits going on to set up a brothel in the Strand (165-177), and with Touchwood Sr taking up residence with the Kixes (V. iv. 76-86), sin in the Cheapside world perpetuates itself. With its cast of characters including all classes, the sin also pervades the world. The way out of this world of sin-indeed, the way to be excluded by this world-is to repent.

One typical feature of Middleton's repentance scenes which is omitted here is the penitent's acknowledgement of receiving grace. Sir Walter says he has awakened to a hope of grace and mercy, but he follows that by saying he is overgrown with sin. His hope of grace and mercy is weaker than Penitent's claim that the eternal spirit feeds his soul with his breath. The repentance also ends bitterly with the Allwits' opposition, leading some critics to treat it as yet another example of the play's suppression of religious perspectives, read as Middleton's own rejection of religious values.

The Allwits' opposition comes in two forms. First, because they cannot comprehend the spiritual conviction which motivates Sir Walter's 
repentance, they believe he has lost his senses and turned melancholy from his wound, fearful of death. Therefore, they try to make him cheerful by bringing his children to him (V. i. 55-56). But as his bastards, the children remind him even more of his sinfulness. What stands literally between Sir Walter and the sight of heaven, darkening his hopes (71-72), is Allwit holding his infant daughter over his face. 37

Soon news arrives that Touchwood Jr has died (116), and that the Kixes are finally expecting a child (142-143). Allwit immediately realizes that Sir Walter is now wanted for murder and, more importantly, that he has lost his inheritance. In Middleton's sharpest piece of irony, the Allwits turn accusatory:

Allwit: I must tell you, sir,

You have been somewhat bolder in my house

Than I could well like of; I suff red you

Till it stuck here at my heart; I tell you truly

I thought you had been familiar with my wife once.

Mistress Allwit: With me? I'll see him hang'd first.

With that said, they expell him from their house to face the officers.

Middleton never lets the tragic circumstances overcome the grotesque. In Act V, scene iii, the Kixes plan a celebration, with a "thwacking bonfire" (8-9), for Mrs. Kix's pregnancy. One of Kix's own servants finds the occasion monstrous (10), recalling the servants' disdain of Allwit in Act I, scene ii. This scene is displaced in time since the birth announcement has already been made in scene one. If in performance, Touchwood Jr's conspiracy with Moll to feign death is not given away (which is how the play 
would be performed consistently with the text), then at the end of scene iii, the audience should think that both lovers are dead, that Sir Walter is arrested for murder, and that he has a successor in Touchwood Sr for his sin. How does one escape this mad world?

The resurrection of the lovers has been regarded as a contrivance by Rowe (147), and it is, insofar as the principals themselves are concerned. However, as with the emblem of the agnus dei, there is more meaning for the audience than the words themselves carry. At a church, at a funeral, as Easter nears, Touchwood Jr and Moll rise from their coffins to be married. What implication does their reappearance have for the penitent? Sir Walter left the stage with his hopes darkened by remembrance of his sins, and with a murder charge awaiting him.

The hope of a penitent for his or her own salvation and resurrection, however, is always based on the resurrection of Christ. The grace which was omitted in his repentance now comes to Sir Walter-that in the feigned resurrection of Touchwood Jr and Moll, his life is more literally resurrected from the hanging which up to that moment awaited him. This point is never explicitly made in the text. However, to an audience who could witness an execution on any given day, and who would be attuned to the religious resonance of the scene, the connection between Touchwood Jr's, Moll's, and Sir Walter's resurrections would have likely been clear even before Yellowhammer enters the scene and informs the wedding guests that 
Sir Walter is now in the knight's ward of the debtors prison (V. iv. 73). ${ }^{38}$ Resurrection is the basis of hope, and with Sir Walter's life saved, and with the lovers married, the play returns to comedy.

The typical critical reaction is to focus on Sir Walter's on-going imprisonment as evidence that his repentance is ineffectual. It does not reconcile Sir Walter to the play's society, but this society has nothing to offer the penitent. As Loughrey and Taylor note, moreover, the knight's ward is not the most stringent section in the prison; the twopenny ward and the hole are worse. As Helvetius notes in The Second Maiden's Tragedy, in a corrupt society, imprisonment for the penitent is not an awful fate:

I shall have more time

And liberty to virtue in one hour

Than all those threescore years I was a courtier.

So by imprisonment I sustain great loss:

Heav'n opens to that man the world keeps close. [97-101]

Alan Brissenden observes that for Sir Walter, "[T]he necessary price for salvation is physical mortification. The other characters are punished too, but their punishment lies in their spiritual desiccation.... Sir Walter at least has a spiritual victory of sorts" (xvii). This price does not mean that Sir Walter earns his salvation, but that by receiving salvation, he also receives the natural consequence of suffering in this life. It is nevertheless mild compared to the execution he faced.

With its sardonic tone, A Chaste Maid in Cheapside could never have been a tragedy, but that it ends up being a comedy is wholly a result of the 
hope offered by its resurrections. The comedy of grace faces greater extremity here than in A Mad World, My Masters, winning a more contested victory, but winning nonetheless.

V. Notes

${ }^{1}$ The quote in the subheading comes from $A$ Trick to Catch the Old One, II. i. 349 .

2Except for The Old Law, the Middleton's tragicomedies have significant repentance scenes-Sebastian in The Witch, Captain Ager in A Fair Quarrel, and the Duchess of Milan in More Dissemblers Besides Women. The Old Law resembles the early comedy The Phoenix by having a disguised ruler superintend the outcome of the play; while there is no significant repentance scene, Cleanthes and Hippolita are already morally motivated. The generic difference between these tragicomedies and Middleton's comedies generally is that important characters in these plays have a strong and misguided commitment to rules of some sort, representative of law-Sebastian to an inviolable betrothal, Captain Ager to duelling codes and honor, and the widowed Duchess of Milan to her vow not to remarry. In The Old Law, the law requires the death of male citizens at eighty, female citizens at sixty years old.

The tragicomedies are largely comedies based on situations of intensified seriousness. Their resolutions are not tragic and the genre, for Middleton, seems to be a category of comedy, like city or romantic comedy.

3It is worth observing here that Middleton's The Phoenix, occasioned by the accession of King James I to the English throne, is a predecessor and possible inspiration for Measure for Measure. See Thomas A. Pendleton's "Shakespeare's disguised duke play: Middleton, Marston, and the sources of Measure for Measure" and Ivo Kamps' "Ruling Fantasies and the Fantasies of Rule: The Phoenix and Measure for Measure."

Complicating the question of the relationship between Middleton's play and Shakespeare's is Gary Taylor's conclusion that Middleton wrote some of the scenes in Measure for Measure. I do not think that suggestion is indisputable, but in either case, the scenes involved are not significant passages about grace in the play. See the "introduction" and the "additional passages" to Measure for Measure in Taylor's edition of Shakespeare's Complete Works and his book Shakespeare Reshaped.

4More will be examined of Witgood's and Sebastian's cases in following chapters. Katharine Eisaman Maus has written on the practices and defenses 
of equivocation in religious controversies and heresy trials (Inwardness and Theatre, chapters one through three). Her research indicates that equivocations were made by both Catholics and Protestants, depending on which group was currently being suppressed. A Biblical precedent for dissembling in the cause of God is Rahab the harlot, who hid the Jewish spies and lied to the authorities of Jericho about where they went (Joshua 2).

5"Reape" is used in the uncorrected first quarto and the second quarto of Michaelmas Term; "rape" appears in the corrected first quarto, copy text of recent editions. In context, both words are indicated, whichever reading one prefers. "Rape" is textually preferable, from which "reap" is easily inferred.

Most of the degenerate characters in A Chaste Maid in Cheapside do not suffer more than slight inconvenience for their sins, making this play an exception to Middleton's common portrayal of reciprocal justice. This play, as will be demonstrated, approaches moral issues from a complementary perspective.

${ }^{6}$ Augustine strongly opposed the theatre, but always on the basis of its use in pagan ritual. It is not necessary to suppose that a Renaissance Christian dramatist would have seen a conflict between holding Augustinian ideas and working in the theatre.

7In The Two Gates of Salvation, Middleton observes of Christ, "Hee went to the Crosse, from the crosse to the Sepulchre, and from that Sepulchre returned home againe into Heaven" (B3r). Other references to the resurrection appear on $\mathrm{F} 1 \mathrm{r}, \mathrm{G} 1 \mathrm{r}$, and $\mathrm{H} 2 \mathrm{r}$.

Ronald Huebert echoes Ayers' reading of the succubus when he discusses the ghost in The Changeling: "It's a remarkably subservient ghost, this faint echo of a spiritual past in the minds of two people who don't want anything to do with it" (608). The ghost represents "the formulas of an obsolete tradition." Of course, therefore, Huebert finds Middleton a "radically secular" playwright.

${ }^{8}$ In "Terence Improved: The Paradigm of the Prodigal Son in English Renaissance Comedy," Ervin Beck identifies a genre in Renaissance drama based on the prodigal son parable. Rarely are all parts of the parable used on stage, but the essentials are that a young man, after reaching maturity, rebels against his heritage, suffers a humiliation, repents, and returns to his heritage (109-110). Beck considers Shakespeare's Henry IV (both parts) and All's Well that Ends Well prodigal-son plays. A Trick to Catch the Old One also appears in Beck's discussion.

${ }^{9}$ Rowe admittedly "avoided dramas whose authorship is still debated," which for him include The Revenger's Tragedy, but he claims, "some of these plays might have provided additional support for the thesis argued 
here" (23). I am not sure how The Revenger's Tragedy, with no obvious relation to New Comedy, would have helped his argument.

10Peter Saccio has edited A Mad World, My Masters for the forthcoming Oxford Complete Works of Middleton. I have corresponded with Saccio about the Brothel/ Once-Ill conundrum, and in addition to a personal response, he has sent me a copy of relevant materials from his critical introduction, textual introduction, and textual notes. I wish to acknowledge his gracious permission to cite his work. The material which will be included in the Complete Works I will cite according to the section in which it will appear; other comments from the letter I am citing as "letter."

Since the time when Saccio submitted his work to his editor, Michael Taylor has had an edition of $A$ Mad World and other plays published. He annotates Penitent Brothel's name, "called Penitent Once-Ill in [stage directions] beginning 4.1 and 4.4 (coinciding with his reformation)" (298). This seems to indicate a change from his earlier conclusion, which, however, is still worth consideration.

11Saccio further explains his rejection of the "Once-IIl" variant on the grounds that Middleton "never put it into the spoken text (as he did Shortrod) and so it had no theatrical effect" (letter). He opts for "the modern principle of consistency in character names" (letter), a solution particularly reasonable for offering a text to be performed. However, I wish to emphasize the pedagogical value of the variants, hoping that they will not be overlooked by students and instructors.

12Penitent Brothel and Master Harebrain share the stage briefly at the end of Act III, scene ii, but without any apparent awareness of each other's presence.

${ }^{13} \mathrm{~A}$ third use of the illness/sinfulness metaphor occurs in the preface of The Two Gates:

The Balsamum of grace healed the wounds of the law, law did both promise and threaten. The Gospell should performe and reconcile. The bitternesse of the law was tasted, but the sweetnes of Grace could not be relished but by hope. It was fit therefore that we lying so sicke, should be kept in hand that a Phisition was comming: and hereupon was Christ promised, even from the beginning: He was promised not once but often. Often, to shewe that God was mindfull of our saving health. [B1v]

${ }^{14}$ The conflation of sinfulness and sickness also appears in The Revenger's Tragedy. When Gratiana repents, she prays, "O you heavens,/ Take this 
infectious spot out of my soul,/ I'll rinse it in seven waters of mine!" (IV. iv. 50-52). Later confessing her wrongs to her daughter Castiza, she says,

I am recover'd of that foul disease

That haunts too many mothers; kind, forgive me,

Make me not sick in health. If then

My words prevail'd when they were wickedness,

How much more now when they are just and good! [IV. iv. 102-106]

As Gratiana asks that she not be made "sick in health," we should not take "Once-Ml" to signify that Penitent has reached sinless perfection. Calvin, we may recall, exhorts Christians to perform "that ordinary repentance which the corruption of nature obliges us to cultivate" (Institutes I: 525).

15The "Courtesan" is the common name for the character in speech prefixes and the criticism, but the other characters also refer to her as "Lady Gullman" or "Frank Gullman." Harebrain does not know, of course, that Lady Gullman is a courtesan. I will follow the convention in referring to the character as the Courtesan.

${ }^{16}$ A play entitled The Family of Love (c. 1602) has been attributed to Middleton, but that attribution has recently been reconsidered. In his authorship study, David Lake splits the writing between Middleton, Dekker, and Lording Barry, author of the play Ram Alley. More recently, Paul Mulholland and Gary Taylor have concluded that Barry is the sole author (Mulholland, Letter). Thus the play will not be included in the Collected Works. Yet, because it was performed by the Children of Paul's, the play was probably familiar to Middleton.

17Middleton's Protestantism should not lead us to infer that Harebrain's judgement of the impropriety of Marlowe's and Shakespeare's poems is also Middleton's judgement; $A$ Mad World is easily as bawdy as anything in Venus and Adonis. However, Harebrain's comments invite questions of critical reception, gender, literacy, and cultural studies: Were these poems read by women as erotica? Was their reading subversive, as the Courtesan's comments about hiding pamphlets in skirts would imply? What does all of this tell us about Shakespeare's early audience, the uses of his texts, and the nature of erotica for women readers? These questions are beyond the scope of this study, but they merit further examination.

18In the dedication of the 1584 Protestant adaptation to the Archbishop of York, Edmund Bunny explains,

I perceived that the booke insuing was willingly read by divers, for the persuasion that it hath to godlines of life, which notwithstanding in 
manie points was corruptly set down: I thought good in the end, to get the same published againe in some better manner than now it is come foorth among them; that so the good, that the reading therof might otherwise do, might carrie no hurt or danger withal, so far as by me might be prevented. For this cause I have taken the pains, both to purge it of certain points that carried either some manifest error, or else some other inconvenience with them: and to join another short Treastise withal, to exhort those that are not yet persuaded, to join with us likewise in the truth of Religion. [*2r]

Bunny excises four sections from Parsons' ninth chapter (on the judgement of sin), predictably those dealing with purgatory: "Of the temporall paynes of purgatories/Of the severitie therof/Of the greate feare, that holie men had therof in olde tyme" and "A certaine vision of the handling of a wicked man in hell, shewed to a holy man" (1582 edition, A2r; omitted in 1584).

${ }^{19}$ These lines conflating sickness and sinfulness locate the intersection of meaning in the woman's body-sect and sex here, and the grave and the vagina to be noted. This is, of course, misogyny. Yet, as the interest of feminist critics in Middleton's canon testifies, Middleton consistently reexamines the social status of women, so that the misogyny here is contradicted in A Trick to Catch the Old One and The Roaring Girl.

Fumiko Takase critiques A Mad World, My Masters on the basis of its antifeminist sentiment, and concludes that the misogyny invalidates the repentances. This reading closely parallels those that invalidate the repentances on the basis of their being part of the general madness of the play. A further problem is the contradiction in her argument. Regarding Mistress Harebrain, Takase observes, "With tears in her eyes and on her knees, Mistress Harebrain swears that no man shall ever wrong her husband's bed" (24). Two paragraphs later, Takase claims, "Mistress Harebrain's adultery is completely forgotten without any visible signs of repentance" (25). Nor does she consider Penitent's claim of responsibility for leading Mistress Harebrain astray (in Act IV, scene iv).

Commenting on A Chaste Maid and Women Beware Women, Ingrid Hotz-Davies is more astute in her conclusions about Middleton's antifeminism:

The question now is: is Middleton an anti-feminist? I think the answer to this is no-much in the same way as he is not a feminist... It seems logical to conclude that Middleton is at his most misogynist when his attention is directed at well defined targets, i.e. when he is at his most satirical. For Middleton, social satire is obviously not the right spot for feminist thought. However, the more Middleton gets involved with the individual psychology of his female characters, the more these antifeminist traits disappear.... It means that Middleton is capable of transcending the misogynist heritage, which he himself may not even 
be free of, in the interests of the complexity and veracity of his characters. In this reading, Middleton can be said to be a feminist in the same degree as for example Shakespeare may be said to be an anti-racist in Othello.

[37-38]

A Mad World, My Masters is satirical, and it fits the circumstances HotzDavies defines as when Middleton is most misogynistic. It is also true that the misogyny is part of his broader scorn of all humanity, informed by the Calvinist doctrine of total depravity. Middleton's "feminism" and "antifeminism" are relative to his time, and they should be historically situated in the criticism.

${ }^{20}$ I have no theatre experience beyond that of a frequent audience member, and I have not found any mentions of a performance of A Mad World, My Masters. My comments here are based on how I think this scene could be acted, though the problems of staging are beyond my expertise. I hope that the play will be performed as interest in Middleton rises.

${ }^{21}$ Flannery O'Connor's use of profanity again closely parallels Middleton's use of obscenity. InWise Blood, Hazel Motes is trying to develop a "Church Without Christ." Yet when he is buying a car, the salesman's boy mindlessly repeats "Christ nailed" and "Sweet Jesus," reminding Motes of the sacredness which is being profaned $(41,43)$, much as the obscenity is marked as sickness.

22The parallel patterning of conversions and repentances as counterpoints to sinful activities is analogous to the multiple plot patterning Richard Levin explores in his 1971 book. Middleton is the central dramatist of Levin's study. Discussing A Mad World, My Masters and Michaelmas Term, Levin observes equivalences between Sir Bounteous and Harebrain, Follywit and Penitent, Quomodo and Lethe, Easy and Rearage (168-183). I am suggesting a split within a single plot before and after repentance, Brothel versus Once-IIl, and in Michaelmas Term, Easy as a victim of Quomodo before marriage versus Easy restored after marriage to Thomasine.

${ }^{23}$ Robert L. Root criticizes and dismisses Charles Hallet's argument because he identifies Penitent's book with the Resolution. While it is now certain that the line Penitent reads does not come verbatim from that book, its thought is consistent with Parsons' thinking. Making the connection between the two books does not contradict the spirit of Middleton's work.

It should also be noted that there is a slight variation between Parsons' 1582 text just quoted ("for the adulterer shall have one kynde of torment") and the Protestant adaptation: "as if the adulterer should have one kind of torment" (117). For Edmund Bunny, the difference in torments for sins may be more symbolic than real. 
24Besides "To Heaven" from The Forest, the first three poems of The Underwoods- "The Sinner's Sacrifice," "A Hymn to God the Father," and "A Hymn on the Nativity of My Saviour"-suggest Jonson's view of the need for repentance for sin.

${ }^{25}$ The language Middleton uses here resembles the language used at the beginning of the Westminster Shorter Catechism (1647): "Question. 1. What is the chief end of man?/ Answer. Man's chief end is to glorify God, and to enjoy him forever." A catechism could represent pre-existing formulas for recalling and understanding doctrine, and although I know of no other text contemporary to A Mad World using similar language, Middleton's use of this language probably reflects early expressions incorporated into the Catechism.

The lines I omitted from the text (19-24) pick up from the reference to "slime, corruption, woman," and continue in the same anti-feminist vein discussed in note 19 above:

What is she, took asunder from her clothes?

Being ready, she consists of hundred pieces

Much like your German clock, and near allied:

Both are so nice they cannot go for pride,

Beside a greater fault, but too well known,

They'll strike to ten when they should stop at one.

Some critics read this as scapegoating. While it is misogynistic, it is more properly read as characterization, such as befits the Courtesan, her Mother, and Mistress Harebrain. The generalization is broad, but may be ameliorated somewhat when Penitent later asks Mistress Harebrain for her forgiveness: "Forgive me, Mistress Harebrain, on whose soul/ The guilt hangs double,/ My lust and thy enticement" (IV. iv. 50-52). The enticement is Penitent's enticement of Mistress Harebrain with the help of the Courtesan.

${ }^{26}$ The test of a convert's spiritual resolve is a common subject in art and hagiography. The temptations of St. Anthony while a hermit include the allure of a succubus. A painted cloth of this scene dated 1499 was once owned by St. Anthony's Church in London (Farmer 26). If this is the same church that became a Puritan center of worship, known then as St.

Antholin's (or St. Antlings in The Puritan and Michaelmas Term), then the painting may have been familiar to Middleton. Similar tests of resolve occur in Foxe's Protestant hagiography, Acts and Monuments.

${ }^{27}$ To suppress one's tendency towards debauchery, Paul recommends a similar appropriation in Romans 13: 14: "But put ye on the Lord Jesus Christ, and make not provision for the flesh, to fulfil the lusts thereof." 
28Both David Farley-Hills and Fumiko Takase suggest that Penitent and Mistress Harebrain are conspiring to hide the truth of their adultery from her husband. Farley-Hills says that Penitent is "entering on a conspiracy of silence with Mrs Harebrain to keep her husband in the dark about their adulterous relationship" (104). Takase asks of Penitent's repentance, "Is it just a trick to silence his love about their illicit liaison, making a fool of her credulous husband?" (24). Act IV, scene iv begins with Penitent finding out from the Harebrains' servant that his master has just left home (5). The sequence of events leading to Harebrain's entrance begins at the conclusion of Penitent's exhortation to his wife:

[Penitent:] ... And she consumes more than his sire could hoard, Being more common than his house or board.

Live honest, and live happy, keep thy vows;

Enter Harebrain [unnoticed].

She's part a virgin whom but one man knows.

Embrace thy husband, and beside him none;

Having but one heart, give it but to one.

Mistress Harebrain: I vow it on my knees, with tears true bred, No man shall ever wrong my husband's bed.

Penitent: Rise, Im thy friend forever.

Harebrain [comes forward]: And I thine forever and ever. [68-77]

Clearly, Harebrain just barely misses the truth of the situation once again. However, his wife and Penitent make no apparent effort to hide the truth from him. Instead, as Henning's brackets in the stage directions indicate, it is Harebrain who is being surreptitious. Furthermore, the line "She's part a virgin" (71) would indicate the truth to a more astute character. Harebrain is the butt of another joke, but not to the extent that the joke itself must cast doubt on the sincerity of Penitent's and Mistress Harebrain's actions.

${ }^{29}$ I have not examined Penitent's comment on courage earlier, but to observe Levine's last point, Penitent tells his servant Jasper, after surviving the Succubus, "When men's intents are wicked, their guilt haunts 'em/ But when they're just they're armed, and nothing daunts 'em" (IV. i. 92-93). The parallel passage occurs when, fearing to pass the "ghost" that stands outside of the door to Philippa's home, Francisco gives up his purpose:

Were this a business now to save an honour, As 'tis to spoil one, I would pass this then

Stuck all hels horrors i' thee: now I dare not. [III. ii. 99-101]

${ }^{30} \mathrm{My}$ discussion of The Widow will focus solely on the similarities and contrasts between Francisco and Penitent, and thus I am leaving out 
consideration of the Ricardo plot. However, his attempt to woo Valeria, the widow, is the plot for which the play is named. As with A Mad World, My Masters, I resist labelling either plot a subplot because both plots seem to occupy essentially equal critical attention.

${ }^{31} \mathrm{My}$ choice of text for discussion of A Chaste Maid in Cheapside is not wholly satisfactory to me. I have both Alan Brissenden's New Mermaids edition and the edition of five plays, including $A$ Chaste Maid, edited by Bryan Loughrey and Neil Taylor, published by Penguin. The critical apparatus, including the introduction, is clearly preferable in Brissenden's edition. However, the text itself is unnecessarily under-edited, including the omission of punctuation and the notation of asides. For example, in Act I, scene ii, Allwit is arguing with two servants that he is their master, rather than Sir Walter, even though Allwit himself continually defers to Sir Walter. In Brissenden's edition, the first servant responds to Allwit,

Negatur argumentum. Here comes Sir Walter, now a stands bare as well as we; make the most of him he's but one peep above a servingman, and so much his horns make him.

[67-69]

From this, one could reasonably, but mistakenly, conclude that Sir Walter is standing bare-headed ("a" is sometimes used for "he"). But when Sir Walter later tells Allwit to put on his hat (77, 81-85), we know that it is Allwit with his hat off. Loughrey and Taylor edit the first servant's speech thus:

Negatur argumentum. Here comes Sir Walter. [Aside to Servant 2.] Now a stands bare as well as we; make the most him, he's but one peep above a servingman, and so much his horns make him. [66-68]

Loughrey and Taylor also prefer quarto readings in circumstances where they are explainable, even if difficult.

The problem with Loughrey and Taylor's edition is that they confuse seventeenth-century satire and bawdry with twentieth-century obscenity. Although $A$ Chaste Maid is stuffed with sexual double-entendre and innuendo, I would suggest that the more pornographic annotations distort the tone of the work towards a greater misogyny and baseness. One may find the language of these annotations in Sir David Lindsay's Ane Satire of the Thrie Estaitis, a late morality play by a Scottish Calvinist. That Middleton himself did not use such language should guide how his works are annotated, preferring clarity over absolute coarseness. I will use Loughrey and Taylor's text for its accuracy; yet I prefer Brissenden's sensitivity to Middleton's tone.

32The watermen criticize Mistress Yellowhammer's cruelty. Their unusually positive characterization in this play has been attributed to 
Middleton's use of their aid in civic pageants and their transport of customers to the playhouses (Bergeron 137). Middleton is among the writers commended in "The Praise of Hemp-Seed," a poem by John Taylor, the Thames waterman and self-proclaimed "water poet" (Steen 37).

33In his suggestive comparison of $A$ Chaste Maid and The Triumphs of Truth. Bergeron does not mention the characterization of Gluttony and Sloth in the pageant, which can serve as a neat summarization of Allwit's character. Error offers the services of Gluttony and Sloth to the new Mayor:

Here's Gluttony and Sloth, two precious slaves, Will tell thee more than a whole herd of knaves; The worth of every office to a hair, And who bids most, and how the markets are, Let them alone to smell. [242]

Both Sir Walter (I. ii. 108; II. ii. 39) and Yellowhammer (IV. i. 240) refer to Allwit as a slave. Allwit, in disguise, describes to Yellowhammer his own contentment with being a wittol: "Ay, glad he may too, 'tis his living:/ As other trades thrive, butchers by selling flesh,/ Poulters by venting conies, or the like, cuz" (IV. i. 234-236). He apparently knows the worth of butchers, poulters, and the like. Furthermore, in the apex of grotesque moments, after the christening, he sniffs the cushions his guests sat upon to detect urine. Allwit embodies the gluttony and sloth of the pageant, claiming of himself, "All's one to him: he feeds and takes his ease" (IV. i. 241).

34In the Introduction to his edition of $A$ Chaste Maid, R. B. Parker identifies the Yellowhammers, the Kixes, and the parson as Puritans (li). The parson, according to Yellowhammer, considers Latin to be papistry (I. i. 82-83), and he might be performed as a Puritan. However, if the parson's opinion is to hold for Puritanism in this play, then the praise that the Puritan ladies give Tim Yellowhammer for attending Cambridge-"the well-spring of discipline, that waters all the brethren" (III. ii. 176-177)-is contravened by the Latin he has learned there (which he is only too happy to exhibit). The Kix connection is equally tenuous: Sir Oliver Kix, according to Parker, might be a Puritan because he shares the same first name with the Puritan in Hengist, King of Kent. The satire of Puritans could be better regarded as limited to the characters identified as such.

35One critic who has remarked on the play's tragic tendency is Caroline Lockett Cherry, who gives the first feminist reading of Middleton's plays. She notes the financial basis for Yellowhammer's opposition to Moll's marriage plans, his potential gain from Sir Walter's wealth: 
The evil effect of this opposition is indicated by the fact that Moll is imprisoned, mistreated, and symbolically killed and buried before she can be united in fruitful marriage; she must, in short, die in order to escape the restrictions this system imposes on her. [54]

36In Brissenden's edition, the scene is Act IV, scene ii.

37While Sir Walter certainly is not an ideal father, one of the common misreadings of his repentance is that it is undercut by his rejection of his children. Anthony Covatta presents such a reading:

When Sir Walter lies wounded, Allwit tells the boys, Wat and Nick, to comfort him and is shocked to see them rejected. One reason for the Allwits' final disavowal of Whorehound could be his rebuffing the children. The Allwits are somewhat venal, but Sir Walter is much more selfish than they. Afraid he is about to die, wrapped in his own fate, his only legacy to his offspring is curses. [153]

Actually, Sir Walter first takes his children to be signs that he is cursed: "O my vengeance!/ Let me for ever hide my cursed face/ From sight of those that darkens all my hopes" (V. i. 69-71). The vengeance is against himself from God for his sin, manifest in his children.

A few lines later, Allwit instructs Wat to "Tell him he hurts his wounds, Wat, with making moan" (86). Sir Walter responds, "Wretched, death of seven" (87). Loughrey and Taylor usefully annotate "death of seven" as Sir Walter's claim to be "responsible for the spiritual death of his seven bastards, and they are signs of his own spiritual death."

Sir Walter does curse the Allwits themselves when he writes his will (99-115); one of the curses against Mrs. Allwit is to behold "ere she dies/ Confusion of her brats before her eyes/ And never shed a tear for it" (113-115). Born outside of a state of grace, in original sin and as bastards, the confusion of the children is inevitable unless they too are awakened to grace and mercy. With Sir Walter soon to leave the stage penniless, and with the Allwits keeping the children to maintain their illusion of a respectable family, Sir Walter is hardly positioned to help the children further, and they do face a wretched future. The curse is against Mrs. Allwit, that she can see that future and be unconcerned about it, much as she and her husband "kept the eyes open still" on Sir Walter's sin and still advanced it. Sir Walter's sentiment is ungenerous, but not unreasonably so, and Covatta's defense of the Allwits seems completely contrary to Middleton's intent.

38Yellowhammer enters with the news that Sir Walter is in the knight's ward before anyone is apparently dispatched to the prison with the news of the lovers' resurrection. Therefore, there is a slight dislocation of time in the order of events. This probably would not be noticeable in performance. 
As we will see in depth in the next chapter, Middleton often uses marriage itself as an emblem of grace, reflecting the love of Christ for the Church. Of the major characters in Cheapside, the chaste maid Moll is certainly the most virtuous, offering the best hope for future triumphs of truth and purity. However, as noted earlier, Touchwood Jr is not her moral equal, having endorsed his brother's adultery with Lady Kix, and his marriage with Moll is never mentioned as divinely ordained.

Instead, their marriage indicates the best hope for reform within Cheapside and this world. As Touchwood Sr eulogizes at their feigned funeral, "Never could death boast of a richer prize/ From the first parent, let the world bring forth/ A pair of truer hearts" (V. iv. i-3). Moll is "The true, chaste monument of her living name/... What nature could there shine, that might redeem/ Perfection home to woman" $(12,15-16)$. The "first parent" is Adam, and the proposed union is the best hope the world offers. The Moll-Touchwood Jr union is likely to be better than the marriages of the Yellowhammers, the Kixes, perhaps the Touchwood Seniors, and certainly the Allwits. But, while significant, this source of potential improvement in Cheapside is not exactly equal, in Middleton's portrayal, to the hope offered by the last Adam, Christ (I Corinthians 15: 45). 
Three:

Marrying the Whore: The Hosea Paradigm

in A Trick to Catch the Old One and Other Plays

Second to the number of repentance scenes in Middleton's city comedies is the recurring occasion of the marriage of a fallen woman. The woman is almost always regarded by the other characters as a whore, but her actions need not include selling her body for men's pleasures. "Whore" is the presumptive designation for any woman whose sexual behavior is thought to be illicit. Moll Cutpurse, for example, is supposedly a whore in The Roaring Girl because she wears men's clothing and refuses to marry, even though she defends her chastity with a sword. Middleton persistently questions the male prerogative to name women as whores, especially when the man himself participates in sexual sin or its moral equivalent. This is the advance in Middleton's treatment of women characters which feminist critics have identified and generally praised. One lesson Sir Alexander Wengrave learns from Moll Cutpurse is to

never more

Condemn by common voice, for that's the whore

That deceives man's opinion, mocks his trust,

Cozens his love, and makes his heart unjust. [V. ii. 247-250]

Social opinion itself becomes the whore, the merchandise that itself makes a sexual object of any woman.

Insofar as the subject is the abuse of chaste women by unjust rumor, Sir Alexander's resolution could just as easily come from Much Ado About Nothing or Cymbeline. But, according to Anne Haselkorn, neither 
Shakespeare nor Jonson ever question the social treatment of actual prostitutes. She identifies three broad attitudes taken to prostitutes in Elizabethan and Jacobean comedy, which she labels as Cavalier, Puritan, and Liberal (20). The Cavalier attitude is that debasement inheres in the occupation, and, therefore, punishment is "accepted, not to reform, but as a concomitant of prostitution" (20). There are, of course, variations in severity among the portrayals, but Haselkorn locates this attitude in the works of Shakespeare, Jonson, and Marston. 1

The Puritan attitude, mainly identified with Dekker, agrees with the Cavalier assessment of the whore's wickedness, but punishment assists in reclaiming her to a righteous life, not just in maintaining social order. "Puritan playwrights deemed marriage an acceptable solution for the whore's ills, but they demanded total repentance and reform" (21). Plays exhibiting this position include The Honest Whore, Parts I and II. Part I, written in 1604, was a collaborative effort of Dekker and Middleton. Though Middleton is the better writer, as of the time of this play, Dekker's solo works, includingThe Shoemaker's Holiday, show the stronger ability. Both writers are Calvinists, and Middleton's interest in the redemption of prostitutes varies by degree, rather than kind from Dekker. Yet even in the Honest Whore plays, the collaborative first part shows greater generosity to Bellafront, the reclaimed whore, than Dekker's solo-written second part. 
Middleton exemplifies the Liberal perspective as Haselkorn defines it:

The cure for the quean's problem generally remains marriage. The Liberal attitude is a realistic one which responds to a less-than-perfect universe and willingly accepts a less-than-perfect solution. The whore who is reclaimed generally marries not her original seducer, but the dubious male whom society feels cannot object to her flawed, frail reputation. [22]

Haselkorn focuses on Middleton, but he shares the Liberal attitude with the lesser dramatists Lording Barry, Nathan Field, Richard Brome, and Thomas Randolph (23). There are variations of course-Country Wench in Michaelmas Term is less sympathetic than the Courtesan in $A$ Trick to Catch the Old One.

One of Middleton's fallen women does complain about the dubious male she marries; the Courtesan of A Mad World, My Masters is chagrined to find out of Follywit, "Oh destiny! Have I married a thief, mother?" (V. ii. 231). However, when he finds out that she has been a quean (257), she pledges, "What I have been is past; be that forgiven,/ And have a soul true both to thee and heaven" (259-260). From Follywit's perspective (as representative of a male prodigal's perspective), the Courtesan is tainted goods; she is the repayment, in divine reciprocal judgement, for his gulling of Sir Bounteous: "Tricks are repaid" with a whore "I see" (261).

Does the Courtesan herself suffer judgment? Sexual desire may partly motivate such characters as Bianca inWomen Beware Women and BeatriceJoanna in The Changeling, but the goal for whores in the city comedies is security, both financial and societal. The Country Wench in Michaelmas 
Term tells Hellgill the pander that, as for her becoming a prostitute, "If I had not a desire to go like a gentlewoman, you should be hang'd ere you should get me to't, I warrant you" (I. ii. 27-28). Prostitution can be explained as a means of making a living for a woman with low prospects. But marriage, as the Courtesan's Mother explains, is the better means in all respectsfinancially, socially, and even sexually: "Thou'st wedded youth and strength, and wealth will fall./ Last, thou'rt made honest" (IV. v. 138-139).

Having been caught in theft, Follywit also pledges reform -"that you may be seriously assured of my hereafter stableness of life, I have took another course" (242-243), the course of marriage. But now that he has the Courtesan's three hundred pound dowry to live from until Sir Bounteous dies (IV. v. 112-113), he has no particular reason to continue thieving, and the Courtesan has no further financial reason to continue in prostitution. Insofar as either marriage partner abides by the pledge each has made to reform, the Courtesan has lost nothing by wedding Follywit. She has only not advanced as far as she had hoped in social standing by marrying a thief.

Of course, the multiple ironies which append to this union cannot be dismissed as easily as the pledges to reform suggest. The Courtesan's own counsel and assistance to Mistress Harebrain shows that she is an expert in feigning religious resolve. Follywit's previous behavior also fails to inspire confidence. And the marriage of the Harebrains shows one breakdown of the bonds of fidelity. Marriage offers an opportunity and demands responsibility. The opportunity, as the Courtesan's Mother notes, is to be 
made honest (IV. v. 139). The responsibility, as the Courtesan pledges, is to be true both to the spouse and to heaven. Whether or not the characters avail themselves of the reformative benefits of marriage, the principle of dual fidelity to spouse and heaven fits every conventional Christian statement of the nature and responsibilities of marriage.

Although Calvin and his followers deny marriage the Roman Catholic status of a sacrament, it remains a mode of common grace in Protestant discourse. A common grace is any favor God shows to any person, whether one of the elect or not. The marriage ceremony of the Book of Common Prayer (1559 edition) presumes the faith of its participants; yet it still mentions kinds of divine favor which can come to any marriage. First is the procreation of children.

Secondly, it was ordained for a remedy against sin, and to avoid fornication, that such persons as have not the gift of continency might marry, and keep themselves undefiled members of Christ's body. Thirdly, for the mutual society, help, and comfort, that the one ought to have of the other both in prosperity and adversity. [290-291]

The general state of marriage also signifies "unto us the mystical union, that is betwixt Christ and his Church" (290). Because this sign was "instituted of God in paradise in the time of man's innocency," it is regarded as inherent to matrimony, whether or not the partners are themselves Christian.

There are actually two tiers of grace presented here. The first is a common grace generally available in marriage-spouses pledged to each other's benefit and a way to avoid fornication. If in Genesis 2: 18, Eve is created as "an help meet" for Adam, the return in the husband's pledge to 
the wife is, "With my body I thee worship: and with all my worldly goods I thee endow" (293). The divine favor bestowed generally on marriage is covenental, dependent on the commitment of each partner to the other, "so either to give their troth to other" (292).

This is not the same level of grace as that which leads a person to salvation, but marriage is an image of the salvific relationship between Christ and the Church, and therefore is emblematic of saving grace. The grace of salvation is intertwined with common grace in the ceremony of the prayer book. The minister blesses the couple with the hope that God would "so fill you with all spiritual benediction and grace, that you may so live together in this life, that in the world to come, you may have life everlasting" (293-294). Another prayer is that God would "sow the seed of eternal life in their minds" (295).

In contrast to the emblem of marriage signifying Christ's relationship to the Church is the image of infidelity or fornication as signifying apostasy. Middleton's most parochial use of this image occurs in A Game at Chess, in which the attempted physical seduction of the White Queen's Pawn is intended to bring her into the black camp, the Roman Catholic Church. While diagnosing the folly of the mad world, Penitent juxtaposes religion and zeal not to apostasy, but to pleasure and lust: "None for religion, all for pleasure burn,/ Hot zeal into hot lust is now tranform'd" (IV. iv. 60-61). With their metaphorical associations, however, apostasy and lust are constantly indicated by each other's presence. 
The conflation of apostasy and sexual sin into a single image of infidelity occurs throughout the Bible. Israel becomes a whore in Ezekiel 16 and 23. In the epistle of James, Christians are rebuked as adulterers and adulteresses for not knowing "that friendship of the world is enmity with God" (James 4: 4). The whore of Babylon in Revelation 17 and 18 is also apostate; in Protestant iconography, The Faerie Queene, and Dekker's play The Whore of Babylon, she comes to represent the Catholic faith.

The representation of apostasy as sexual sin (and vice versa) which seems to have most influenced Middleton is the story of the prophet Hosea. Hosea becomes a living allegory as God tells him to marry a whore, Gomer, and to name their children to represent upcoming divine judgments (Hosea 1:2-9). The words of God to Israel become intertwined with Hosea's words to Gomer in chapter two, so that Hosea's complaint against Gomer's continuing prostitution fades into God's complaint against Israel's Baal worship. Although the prophecy continues, the story of the marriage ends in chapter three with Hosea purchasing Gomer's release from prostitution, presumably from a pander.

Middleton does not refer explicitly to Hosea in his dramatic versions of the marriage of whores. However, he cites the book of Hosea five times in The Two Gates of Salvation; three citations come from the first two chapters. Hosea 2: 23 declares God's intention to favor the Israelites in spite of their apostasy: "I will have mercie upon her that was not pittied, and I will say unto them which were not my people, Thou art my people, and 
they shall say, Thou art my God" (H1r). Paul quotes Hosea in Romans 9: 25-26, applying the text to the salvation now offered to the Gentiles. Middleton's annotation to this pair of verses is, "Our Vocation is free, and of grace, even as our Prædestination is" (G4v). Vocation, here, is the call to be one of God's people; the call originates from God to those on whom he will have grace. It is free, and in the context of Hosea, in spite of a complete lack of merit-"mercie upon her that was not pittied." Middleton's annotation is characteristically Calvinist and specifically pertinent to this reading of the marriage of the whores in his plays.2

In Michaelmas Term, the marriage of the Country Wench and Andrew Lethe does not lead to their religious resolve. However, the common grace provision of a way to avoid fornication motivates the Wench to pursue the union: "Master Lethe, we may lie together lawfully hereafter, for we are coupled together before people enow, i'faith" (V. ii. 5-6). As usual with the male characters espoused to a whore, Lethe wants nothing to do with this union. But in a twist of judgment, he is thrust into a subjection parallel to the needy position of the whore/Israel in Hosea. The Judge rules that he must marry the Country Wench, and that he must also be whipped unless he can find a person "whom you have most unnaturally abus'd" willing to "beget your pardon" (V. iii. 133-134).

Apropos of his name, Lethe has been characterized as forgetful of social acquaintances, recent events, and even of his own family. His forgetfulness 
is not always accidental. When he hires his own mother as his servant, he recognizes who she is, but he will not admit their relationship because she would reveal his formerly low social status. That status is evident in his true surname, Gruel. On the other hand, Lethe has so altered his outward appearance that Mother Gruel does not recognize him at all. Therefore, when he has to find a person willing to pardon his abuse, he is rebuffed by Quomodo, Thomasine, and Easy; he must then persuade Mother Gruel that he is indeed her son. Will she have mercy on him that was not pitied by the judge and the other characters?

Mother Gruel's first response is to deny their relationship: "Call'st me mother? Out, I defy thee, slave!" (V. iii. 145-146). The judge observes, "He's justly cursed; she loathes to know him now;/ Whom he before did as much loathe to know" (151-152). This rejection parallels the denial in Hosea 1: 10 by which God previously rejected Israel: "In the place where it was said unto them, Ye are not my people ..." (Two Gates H1r). Mother Gruel is soon brought to recognize and acknowledge her son; she chides him then for his degeneracy since he arrived in London. This seems sufficient to release him from the punishment of whipping. The parallel acknowledgement in Hosea 1: 10, which completes the verse, is, "... it shall be said unto them, Ye are sonnes of the living God." Neither Lethe nor the Country Wench give any indication of repentance, but then neither does the whore/Israel before she is called by Hosea and God. Both Lethe and the Country Wench receive common grace, dramatized in forms parallel to Hosea's text, grace which by 
Calvinist definition is undeserved. As with the marriage of Follywit and the Courtesan, the efficacy of this common grace depends upon the couple's future fidelity, but because the Country Wench claims to want to "lie together lawfully hereafter," there is little reason to doubt her resolve.

The marriages of the Courtesan in A Mad World, the Country Wench in Michaelmas Term, and the Welsh whore in $A$ Chaste Maid are minor developments of the redemptive paradigm suggested by Hosea. ${ }^{3}$ In $A$ Trick to Catch the Old One, the effort to marry off the Courtesan to Walkadine Hoard forms the central complication of the major plot. Other dramatic patterns come from New Comedy and the prodigal son play. The title of the play itself pithily recalls the standard New Comedy overthrow of the senex by the adulescens. The problematic moral nature of New Comedy, discussed earlier in reference to $A$ Mad World, is ameliorated by combining its conventions with those of the prodigal son play. Ervin Beck identifies a sub-genre of prodigal son plays, usually comedies, which began with the late moralities (like Mundus et Infans) and developed in the mid-sixteenth century by England's Christian Terentian dramatists. They usually owe some part of their plot structures to the prodigal son parable in Luke 15: 11-32. Rarely are all parts of the parable used on stage, but the essentials are that a young man, after reaching maturity, rebels against his heritage, suffers a humiliation, repents, and returns to his heritage (Beck 109-110). Other prodigal son plays include both parts of Henry IV, and Michaelmas Term. 
The usual argument over $A$ Trick to Catch the Old One is on the moral nature of Witgood, the protagonist whose behavior has given critics opportunity to question the sincerity of his repentance at the play's end. As with $A$ Mad World and A Chaste Maid, the religious emphasis of this play has either been dismissed as of a piece with an overriding secular cosmology, or ironized by its juxtaposition to that cosmology: $A$ Trick's "world seems unable to accommodate some of the central tenets of both Christianity and Roman comedy" (Rowe 84). One may consult George Rowe, P. K. Ayers (both discussed in chapter two), and David Mount for the representative arguments. They do not have to be re-addressed here, but consideration must be given to Witgood's moral nature and motivations in order to understand the redemption of the Courtesan.

Middleton's solution for combining the conventions of New Comedy with the prodigal son play is to start with the wastrel's resolution to give up his prodigality. 4 As the play starts, Witgood has already hit the bottom in material circumstances: "All's gone! still thou'rt a gentleman, that's all, but a poor one, that's nothing. What milk brings thy meadows forth now? Where are thy goodly uplands and thy downlands? All sunk into that little pit, lechery" (I. i. 1-4). Witgood's losses were made possible by his moral irresponsibility, but they were brought about by his uncle, the usurer Pecunius Lucre, who has foreclosed on a mortgage. Witgood repeats Lucre's justification for gulling a relative, "a principle in usury": 
He that doth his youth expose To brothel, drink, and danger, Let him that is his nearest kin Cheat him before a stranger. [I. i. 14-17]

Witgood's reformation still involves subverting the values of his uncle. Lucre is a New Comedy senex, the explicit target of Witgood's trick: "I shall go nigh to catch that old fox, mine uncle" (I. i. 78-79). The trick is to convince Lucre that Witgood has a good marriage prospect in the "rich widow" Jane Medlar (the Courtesan in disguise). With the hope of gaining even more money by future gullings, Lucre restores Witgood's mortgaged lands and inheritance.

But Lucre is not the only senex to be tricked. His rival in usury, Walkadine Hoard, immediately senses Lucre's motivation and decides to woo the widow for himself. Hoard has three motivations-defeating Lucre, bedding a young wife, and gaining control of her money. Since the Courtesan actually has no money nor social standing, she and Witgood assimilate this unexpected development into further trickery-marrying the Courtesan to Hoard and getting him to pay off Witgood's creditors, nullifying Witgood's supposed claim to the "widow's" affection. This trick is improvised, drawing on Witgood's best wit: "Let's send up for our wits, now we require their best and most pregnant assistance!" (III. i. 118-119).

Insofar as all of this trickery is intended to fulfill a resolution to reform, a third "old one" is Witgood's unregenerate "old man" of Pauline doctrine. Ephesians 4: 22 instructs, "Put off concerning the former conversation the old man, which is corrupt according to the deceitful lusts." In place of the 
old man, the Christian is to "put on the new man, which after God is created in righteousness and true holiness" (4: 24). In II Corinthians, what Ephesians instructs is regarded as accomplished fact: "Therefore if any man be in Christ, he is a new creature: old things are passed away: behold, all things are become new" (5: 17). In his public repentance, Witgood kneels, saying: "And here for ever I disclaim/ The cause of youth's undoing, game" (V. ii. 177-178). The new Witgood rises (resurrects?) and pledges, "Lend me each honest hand, for here I rise/ A reclaimed man, loathing the general vice" (190-191).

A fourth old one is the devil, emblematized in the character of "old Harry" Dampit (I. iv. 71). Old Harry is a nickname for the devil, and his surname Dampit (damned pit) further suggests his hellish character. Witgood describes him as "the most notorious, usuring, blasphemous, atheistical, brothel-vomiting rascal, that we have in these latter times now extant" (I. iv. 13-14). Another character compares him to the picture of Satan in Revelation 20: 2: "Did not I tell you he lay like the devil in chains, when he was bound for a thousand years?" (IV. v. 6-7). Dampit does not participate in any plot; rather, his character represents the extreme to which the other characters can sink, another instance of Middleton's demonic grotesque. There is no trick within the play that catches Dampit; instead, he drinks himself into a stupor and dies. Yet because he represents the devil, his values are contradicted by the repentances of Witgood and the Courtesan, the tricks that defeat the devil. 
Like Penitent in his initial scapegoating of women for his fall, Witgood initially blames the Courtesan for his destruction:

Courtesan: My love.

Witgood: My loathing! hast thou been the secret consumption of my purse? and now com'st to undo my last means, my wit? [I. i. 27-29]

In contrast to Penitent, however, Witgood's misogyny is turned back upon him, the Courtesan asserting his own culpability for his fall and hers:

Courtesan: I have been true unto your pleasure, and all of your lands thrice racked was never worth the jewel which I prodigally gave you, my virginity;

Lands mortgaged may return and more esteemed, But honesty, once pawned, is ne'er redeemed.

Witgood: Forgive: I do thee wrong

To make thee sin and chide thee for't.

Despite the religious connotation of Witgood's apology, the Courtesan does not relent in her rebuking for another five lines, gaining the upper hand in their spat. Witgood responds,

I prithee, make me not mad at my own weapon, stay (a thing few women can do, I know that, and therefore they had need wear stays); be not contrary. Dost love me? Fate has so cast it that all my means I must derive from thee. [45-48]

The misogyny of Witgood's parenthetical aside undermines somewhat the audience's reaction to his resolve to reform. The Courtesan, however, is always above the statements of misogyny. She has a public reputation as a courtesan, strumpet, quean, and whore (I. i. 105-106; V. ii. 86-108). But Witgood himself later admits their monogamy: "I durst depose for her/ She ne'er had common use, nor common thought" and "Excepting but myself, I dare swear she's a virgin" (V. ii. 118-119; 148-149). 5 Her reputation 
notwithstanding, the Courtesan is the most moral character in this play. She loves while Witgood still loathes. Witgood's moral nature develops through the play, and it is significant that he explicitly follows the Courtesan's example in repentance:

[Courtesan:] These and thousand thousand more, New reclaimed, I now abhor.

Lucre: Ah, here's a lesson, rioter, for you.

Witgood: [kneeling] I must confess my follies; I'll down too. [V. ii. 173-176]

About Witgood's reformation, Anthony Covatta observes, "Critical opinion has not often seen that here and in other Middleton comedies moral patterns sometimes correspond with economic patterns instead of being inverse to them" (112). This same thought leads Joseph Messina to remark that the evidence for Witgood's reform is equivocal $(127,131)$. As noted with Helvetius and Sir Walter Whorehound, not all of Middleton's penitents prosper, nor do they expect to. However, when in his reduced state Witgood turns to repentance and renewed prosperity, he parallels the prodigal precedent who leaves the swine trough for his father's feast.

Furthermore, his intention to reform is restated several times. ${ }^{6}$ Once the Host agrees to help Witgood marry the "rich widow," he inquires about plans for more carousing: "Shall we then see our merry days again?" (I. ii. 56). Witgood answers with a crucial reservation given in an aside: "Our merry nights-which never shall be more seen" (57). Later, in soliloquy, he makes a vow to reform if he is able to regain his mortgage: "Oh! that I had 
the mortgage from mine uncle as sure in possession as these trifles [gifts]! I would forswear brothel at noon day, and muscadine and eggs at midnight" (III. i. 86-89). Audiences are used to dismissing such vows as insincere; what would be unexpected is for Witgood to mean what he says.

The test of his character comes soon after, when he has an opportunity to act for someone else's benefit. Witgood's full name, Theodorus Witgood, has usually been interpreted to refer to the congenial treatment of his character. With "Theodorus" meaning "a gift of God," his full name is commonly annotated as "cleverness is God's gift to man."7 This makes Witgood the beneficiary of the grace which his name signifies, much as Gratiana is the recipient of grace in The Revenger's Tragedy. Yet he might also be regarded as a source of grace, thereby benefitting himself and giving grace to another.

Once the plan to get Lucre to return Witgood's mortgage has been set in motion, the Courtesan reveals to Witgood that Hoard has begun to woo her. Witgood's advice is for her to advance her own fortune:

Witgood: Wench, make up thy own fortunes now, do thyself a good turn once in thy days. He's rich in money, moveables, and lands; marry him, he's an old doting fool, and that's worth all; marry him, 'twould be a great comfort to me to see thee do well, i'faith; marry him, 'twould ease my conscience well to see thee well bestowed; I have a care of thee, i' faith.

Courtesan: Thanks, sweet Master Witgood.

Witgood: I reach at farder happiness: first, I am sure it can be no harm to thee, and there may happen goodness to me by it. Prosecute it well: let's send up for our wits, now we require their best and most pregnant assistance! [III. i. 109-119] 
Clearly, Witgood's interest in his own recovery remains a motivating factor: "there may happen goodness to me by it." Nevertheless, by stating his care for the Courtesan, he has advanced, and continues to advance, from the selfabsorption which causes him to call the Courtesan his loathing in Act I, scene $i^{8}$

As indicated earlier, Witgood's moral reformation follows the Courtesan's example. When he enlists her participation in fooling Uncle Lucre, he describes her aid as the assistance of love and fate:

[Witgood:] Dost love me? Fate has so cast it that all my means I must derive from thee.

Courtesan: From me! Be happy then; What lies within the power of my performance Shall be commanded of thee. [I. i. 47-51]

The crucial difference between "fate" as Middleton uses the term and its use in New Comedy and Greek tragedy is the presence of love; this is not the impersonal, inscrutable force of the ancients, but divine providence.

The Courtesan's love is remarked in the Host's description of Act II, scene $i$. There, the Host pretends to be a servant of the "rich widow," inquiring in London of Witgood's reputation and means. The real intent, of course, is to suggest to Uncle Lucre that Witgood has found a wealthy marriage prospect. TheHost describes Witgood to Lucre as,

A country gentleman too, one whom your worship knows not, I'm sure; h'as spent some few follies in his youth, but marriage, by my faith, begins to call him home, my mistress loves him, sir, and love covers faults, you know: one Master Witgood, if ever you have heard of the gentleman?

[II. i. 45-49] 
Although Witgood intends to marry Joyce Hoard, the essential points are factual-he has spent some follies in his youth, he intends to correct his past by marriage, and the Courtesan loves him.

"Loves covers faults" has been annotated bawdily in both the Loughrey edition and Michael Taylor's more recent edition: "presumably there is a bawdy innuendo here since faults are cracks, fissures (Loughrey); as the faults are the man's the words may refer to the woman covering the man in coupling" (Taylor 347). The contortions into which this phrase is twistedwho has the cracks? who does the covering?- - can be redressed by supposing that any bawdiness is secondary at most to the overlooked Biblical allusion. In the Geneva Bible, Proverbs 10: 12 states that "love covereth all trespasses." Proverbs 17: 9 says, "He that covereth a transgression, seketh love." Peter instructs, "But above all things have fervent love among you: for love covereth the multitude of sinnes" (I Peter 4: 8).

The operations of grace and love create a new person, one whose spiritual value exceeds the specific shortcomings of the individual. If Witgood's moral character is less than spotless, the love of God, of the Courtesan, and, eventually, of Joyce covers his faults. A few lines after the Host's description, Lucre exclaims of Witgood, "Can a man of such exquisite qualities be hid under a bushel?" (II. i. 69-70). Lucre is insincere, but with his faults covered, the reclaimed Witgood fits the source of Lucre's line: "Neither do men light a candle, and put it under a bushel, but on a candlestick; and it giveth light unto all that are in the house. Let your light 
so shine before men, that they may see your good works, and glorify your Father which is in heaven" (Matthew 5: 15-16).

As with Witgood, the doubts about the Courtesan's motivations may be answered by her own private declarations. The frequent dismissal of her concluding repentance does not account for her hope of spiritual renewal in marriage to Hoard: "Though I have sinned, yet could I become new,/ For, where I once vow, I am ever true" (IV. iv. 142-143). Here, the concept from Ephesians 4: 22-24 of putting off the old sinful self and replacing it with the renewed self is merged with her marriage vow, so that the two thoughts are inseparable in effect. Although Middleton does not quote directly from the prayer book ceremony, the marriage scene emphasizes the responsibility of fidelity to maintain the new relationship: "Join hearts, join hands,/ In wedlock's bands,/ Never to part/ Till death cleave your heart;/ You [Hoard] shall forsake all other women;/ You [the Courtesan] lords, knights, gentlemen and yeomen" (IV. i. 1-6).9

As far as the original tricks were planned, they were accomplished by Act IV, scene i. However, Middleton introduces another complication which allows him to develop the Hosea paradigm of grace further. Once it has become clear that Witgood has lost the "rich widow" to Hoard, Witgood's creditors beset him for immediate payment or arrest for his debts. Under this circumstance, Witgood briefly suffers the same fate as Sir Walter does; as Witgood is taken away, he laments, "I am in hell here, and the 
devils [creditors] will not let me come to thee [the Host]" (IV. iii. 61-62). In contrast to what happens to Penitent, Sir Walter, and Helvetius, however, this problem is not so much a test of Witgood's resolution as it is a set-up for a parallel emblematic dramatization of an incident from Hosea.

Witgood sends a letter to the Courtesan, revealing his straitened circumstances and enlisting her further aid. The plan is for him to allege, and for her to support, a precontract which has been broken by her marriage to Hoard. Then she suggests to Hoard that he get a signed release from Witgood in exchange for paying off his debts. Once again, in another aside, the Courtesan states her motive for participating in this new plot as her care for Witgood: "Alas, his creditors so merciless! my state being yet uncertain, I deem it not unconscionable to furder him" (IV. iv. 103-104). Hoard agrees to paying Witgood's debts to preserve his own marriage, and he prays ironically that Witgood will agree to the release: "Pray heaven he be in the right vein now to set his hand to't, that nothing alter him" (145-146).

By, in a sense, purchasing the Courtesan from Witgood, Hoard acts further like Hosea, who redeems Gomer from the pander:

Then said the Lord unto me, Go yet, love a woman beloved of her friend, yet an adulteress, according to the love of the Lord toward the children of Israel, who look to other gods, and love flagons of wine. So I brought her to me for fifteen pieces of silver, and for an homer of barley, and an half homer of barley: And I said unto her, Thou shalt abide for me many days; thou shalt not play the harlot, and thou shalt not be for another man: so will I also be for thee. [3: 1-3]

"Hosea" is not a role that Hoard has intended to play, but then Hosea himself is not keen for his marriage (2: 2). However, by marrying the 
Courtesan and by redeeming her with a payment for the alleged precontract, Hoard has enacted her redemption in a manner specifically parallel to the prophet's life. ${ }^{10}$

While this reading of $A$ Trick emphasizes theology over morality, the main objection to the moral readings still needs to be addressed-that the tricks are built on deceptions, which, therefore, invalidate their supposed moral significance. As was briefly noted in chapter two, part of the answer is that the tricks operate reciprocally to the gullings that occur before the play begins. But we may also think of the nature of grace-that it gives blessings to the undeserving, that by love it covers faults, that it is opposed to the condemnation of law. As Witgood contemplates his course of action, what he looks for is, "Any trick, out of the compass of law, [which] now would come happily to me" (I. i. 25-26). Law points out the faults, the deceptions, the prodigality, the whoredom; love and grace cover the old faults, redeem the person from them, and create a new person.

That blessings come despite human intentions can be noted in a previously neglected pun. One of the recurring curses is for one character to wish a "pax" on another. Pretending to recall Witgood's wealth to the "rich widow's" agent (the Host), Lucre cannot think of a name for his estate: "Pax on't; I can never hit of that place either" (II. i. 99). Later, the Courtesan advises Hoard to pay off Witgood's debt, "Discharge 'em quite: a pax on him, let's be rid of a rascal!" (IV. iv. 130-131). The creditors then tell Witgood to 
forget his precontract and "Take hold of [Hoard's] offer; pax on her, let her go" (197). The Courtesan probably intends the duplicity of the pun, wishing peace on Witgood while being thought to wish him ill. The exchange of peace for the pox does not come to one character however, the devilish Dampit who is actually cursed-"a pox search you" (I. iv. 31-32). 11

In this context of grace, love, blessing (even if unintended), and resolution, the confessions and repentances of the Courtesan and Witgood in the last scene are to be expected. The Courtesan acknowledges her previously fallen state to Hoard, but ties her redemption from whoredom to their marriage:

Marrying one of us, you both save a sinner, and are quit from a cuckold for ever.

And more, in brief, let this your best thoughts win, She that knows sin, knows best how to hate sin.

[V. ii. 136-140] Then she kneels before the crowd: "Lo, gentlemen, before you all/ In true reclaiméd form I fall" (V. ii. 153-154). Her new form is married, redeemed (in a manner paralleling Hosea's wife), spiritually renewed, and all in accord with the resolution and love she has demonstrated throughout the play. Although Hoard has married the whore to his brief disappointment, we should not lightly dismiss the Courtesan's explanation of her benefit to him-that she knows what it is to be fallen, and that she hereby forsakes those ways for fidelity.

Witgood follows the Courtesan's example, "a reclaimed man, loathing the general vice" (191). The problem with the moral readings of this play, 
and the critics of those readings, is that they have all supposed that Witgood is a static character, ending the play with the same morals he begins with.

Instead, the victory he gains over the old ones coincides with the transformation of his character by the Courtesan's example. Like the poxes that end up as peace, it is the reprobation, signified by the previous whoring, that is undermined by grace.

\section{Notes}

1In Measure for Measure, Lucio is sentenced by the Duke to marry "any woman wrong'd by this lewd fellow, / As I have heard him swear himself there's one/ Whom he begot with child" (V. i. 514-516). Lucio admits to consorting with whores, with Mistress Overdone as his procuress (I. ii. 43-45). However, no character is introduced in the text with whom he has had sexual relations. The Duke's penalty is represented solely as Lucio's punishment. Such a marriage would be more characteristic of Haselkorn's "liberal" classification, but any implications as to how this marriage would work out for the woman are left undeveloped.

Haselkorn's definition of Middleton's perspective complements the reading I am presenting of his work. However, the sympathetic portrayals of Mistress Quickly in the Henriad and Merry Wives and Dol Common inThe Alchemist problematizes Haselkorn's interpretation of social exclusion within the play society as Shakespearean and Jonsonian authorial judgment. The exclusion, furthermore, is class-based; if Mistress Quickly loses the company of Prince Hal, she still has her associates at the Boar's Head Inn.

2In A Looking Glass for London and England, Thomas Lodge and Robert Greene set a tale in ancient Assyria to allegorize on current spiritual conditions. They use Hosea as a choric commentator who draws out the lesson to be learned from the presented events. Source studies have shown the influence Greene has had on Middleton. Middleton also wrote a prologue and epilogue for a revival of Greene's Friar Bacon and Friar Bungay. Hosea, therefore, was represented in the drama of Middleton's time, in a text with which he was probably familiar.

3In his satire on scholasticism in A Chaste Maid in Cheapside, Middleton uses Tim Yellowhammer's marriage to the Welsh whore as the reversal of his abuse of logic. Hoping to further ingratiate themselves to Sir Walter, the Yellowhammers agree to wed their son Tim to Sir Walter's courtesan, 
posing as a Welsh Gentlewoman and Sir Walter's niece. Sir Walter wants to marry her off to free himself to pursue Moll.

Tim, newly graduated from Cambridge, has a naive faith in his ability to prove any proposition by logic, especially if he can state his arguments in Latin. One of his claims is, "Tll prove a whore to be an honest woman" (IV. i. 38). Inevitably, he is given his opportunity, and he must admit, "I grant you I may prove another man's wife so,/ But not my own" (V. iv. 108-109). However, the Welsh whore herself claims, "Sir, if your logic cannot prove me honest,/ There's a thing call'd marriage, and that makes me honest" (114-115). The focus of this plot is on the satire rather than the religious implications of the situation, but the Welsh whore's claim still recalls the Middletonian assumption of the reformative benefits of marriage.

4This solution to the problem of Christianizing New Comedy paradoxically stands New Comedy on its head: youth may triumph, but by returning to moral standards the elders often fail to uphold (Beck 111).

5Similar to Penitent's claim that a woman can be partly a virgin, Witgood's exception of himself amounts to an essential contradiction-the Courtesan is, therefore, not a virgin. One line hints that the Courtesan may have had more sexual partners than just Witgood. When describing his plan to her, Witgood recommends a cohort in their scheme: "I have acquaintance with a mad host, never yet bawd to thee" (I. i. 66-67). With this hint stated negatively, however, and by Witgood, this is not enough to conclude that she "had common use." The essential point is that she was not a prostitute in the usual sense.

${ }^{6}$ Both Joseph Messina and Murray Biggs cite Witgood's earlier resolutions in support of taking seriously his repentance in Act V. Although a brief note, Biggs' article is closest to the reading I am developing here.

7"Theodorus" is first used in Watson's edition at I. iv. 38. The annotations may appear with this line or at the dramatis personae, depending on each editor's choice. The annotation in the Loughrey and Taylor edition is mistaken; it reads "Theodorus" as "love of God." The person to whom Luke dedicates his gospel and the Acts is Theophilus $(1: 3 ; 1: 1)$, a name that would be used for "love of God."

${ }^{8}$ One may well ask why Witgood does not marry the Courtesan himself if he has such care for her. Insofar as the Courtesan is in fact not a rich widow, she does not provide enough means to advance fully Witgood's material recovery. That is why Witgood romances and marries Hoard's niece (though this romance is treated in a most cursory fashion). Furthermore, Witgood's own means at the beginning of the play offer no financial advantages over Hoard for the Courtesan. These considerations appear 
unromantic and cynical to us, but they reflect the social conditions of the Jacobean age. The tragic circumstances of Women Beware Women begin with a marriage which presumed to disrupt social class distinction, Bianca forsaking her inheritance to marry the penniless Leantio.

The plot of $A$ Trick to Catch the Old One is, however, a construction, and different outcomes could have been written. While Hoard romances the Courtesan, one of his assistants informs the "rich widow" that Witgood is broke. She answers, "On my knees I vow/ He ne'er shall marry me." Witgood, looking in behind a curtain, remarks, "Heaven knows he never meant it!" (III. i. 189-191). This suggests that God observes Witgood's thoughts without interference, even though his thoughts are self-centered. By contrast, in The Roaring Girl, Sebastian treats his courtship of Mary Fitzallard as the fulfillment of divine predestination: "'Tis in heaven's book/ Set down that I must have thee" (I. i. 78-79).

${ }^{9}$ Middleton uses essentially the same wedding speech in A Chaste Maid in Cheapside, V. iv. 35-40.

10Witgood's alleged precontract suggests another Biblical parallel. In Romans 7, living under the law and its condemnation is compared with living in a first marriage, such as would be in force from a precontract. Freedom from the first marriage to marry another is thus comparable to the spiritual freedom provided by grace. This trope is even more applicable to the circumstances of Thomasine in Michaelmas Term, discussed in the next chapter.

${ }^{11}$ All recent editions follow the first quarto of 1608 when using pox (to curse Dampit) or pax (in Lucre's, the Courtesan's, and the creditor's speeches). Pox and pax are not confused in Middleton's other plays, including those issued by the same printer, so I am concluding that my reading of a pox/pax pun represents Middleton's textual intention. 


\section{Four:}

Sodomy, Salvation, and the Stage: Satires, Michaelmas Term and The Roaring Girl

Generally, this study has focused on issues with broad application to the religious problems of Middleton's day: With reference to Penitent Brothel and Walter Whorehound, how do people attain salvation? How do the metaphorical references to apostasy as adultery relate to Middleton's redemptions of fallen women through marriage? Although interest in Middleton fell away from the end of the Restoration until the latenineteenth century, these broad issues raised in his works have remained pertinent and constant across the Christian spectrum. For any Christian, the questions of what is true and how one is saved are crucial.

I. Unspoken Things in the Historical, Literary, and Critical Contexts

In the context of these broader emphases, then, a chapter on sodomy in Middleton's works has a specificity which needs a justification. Interest in the problem of sodomy has not remained prominent in Christian discourse from Middleton's day to our own, perhaps because sodomy is traditionally the sin for which "it is a shame even to speak of those things" (Ephesians 5: 12). The silence is replicated in the application of this verse, which makes no mention of what sin it is shameful to speak. This is not to say that sodomy has not always been practiced, or that Christian writers, theologians especially, have not said much about it. Rather, comment about sodomy fluctuates according to the perceptions of its occurrence. If a problem is not thought to exist, there is no need to discuss it at length. By contrast, in 
Christendom (including in the arts), salvation, apostasy, and grace always matter; so they are always discussed.

One of the ironies of modern political discourse is that in references to "traditional family values," an actual tradition is rarely articulated. Does the tradition consist mainly of silence about what it is even a shame to speak? A tradition of silence is not a particularly useful basis for conducting an argument.

Another irony arises: The very grounds for constructing an antisodomy tradition could come from the research findings of recent gay and lesbian studies. ${ }^{1}$ For example, Alan Bray's Homosexuality in Renaissance England (1982) and Judith Brown's Immodest Acts: The Life of a Lesbian Nun in Renaissance Italy (1986) necessarily focus much of their attention on the ecclesiastical, civil, and social strictures with which homosexual persons had to contend. The introduction to Brown's book surveys theologiansAugustine, Ambrose, John Chrysostom, Anselm, Thomas Acquinas, and others-condemning lesbian acts particularly, but in contexts that usually condemned male homosexuality as well. Bray examines ways in which sodomy was associated with treachery, atheism, witchcraft, and papistry, was therefore proscribed, and was prosecuted. In both books, of course, the authors are also interested in the inconsistencies of the strictures and the ways in which homosexual persons either exploited them or otherwise tried to accommodate themselves to their circumstances. However, to make these 
observations, or to deconstruct these strictures is to state the discourses which could form the components of an anti-sodomy tradition. The silent tradition has been outed. 2

Similar contradictions may be observed in the criticism of Middleton's texts. Except for a footnote in George R. Price's 1976 facsimile edition of Michaelmas Term, ${ }^{3}$ only Theodore Leinwand in 1994 has commented in print on the apparent sodomy in this play. Instead we have what must be taken as a denial of sodomy in an annotation from the most frequently used edition of the play. In Act I, scene i, Quomodo instructs his spirit assistant Shortyard on how to ruin their victim Richard Easy:

Drink drunk with him, creep into bed with him, Kiss him and undo him, my sweet spirit. [I. i. 127-128]

The editor Richard Levin annotates "bed": "Elizabethan men slept together as a habit of friendliness (Sampson); see II. iii. 156." That men slept together is no doubt true; however, the passage Levin cross-references (II. iii. 156) strongly indicates that Shortyard's union with Easy happens in a sexual manner offstage:

[Shortyard:] Why, our purses are brothers; we desire but equal fortunes; in a word, w'are man and wife; they can but lie together, and so do we.

Easy: As near as can be, i'faith. [II. iii. 154-157] Shortyard's and Easy's comparison of their activities to a married couple's would probably recall for the Jacobean audience Leviticus 20: 13 forbidding 
same-sex sexual unions: "If a man also lie with mankind, as he lieth with a woman, both of them have committed an abomination."

The very passage Levin cross-references in his annotation of I. i. 127 makes it difficult to maintain his silence about the sodomy-which is not implicit, but explicit-in Quomodo's instruction to Shortyard to kiss and undo Easy. It is beyond the scope of this study to consider Levin's political views, which may have nuances well beyond his ideas about interpreting literature. However, his general dislike for readings of literature emphasizing gender is a matter of public record, a subject of PMLA Forum letters. Also notable is Levin's reliance on a tradition for his interpretation: the "Sampson" he cites in his annotation is Martin Sampson whose edition of Middleton plays was published in 1915. Levin's silence about the sodomy here seems to be a knowing silence; as such, it parallels the silence about the tradition in recent political discourse.

Considerations of sodomy in Middleton's texts have grown with the increase of interest in gay studies in the mid-1980s. So far, in the critical literature published since 1982, ten Middleton texts have been noted to refer to sodomy, sodomites, or homoerotic situations. They begin in 1599 with Microcynicon, a poetic satire, and conclude around 1619 with the play More Dissemblers Besides Women. 4 The criticism has generally succeeded in revealing the flux of pervasive sexual references in these texts. What does 
not appear in the criticism, however, is any reference to Middleton's Christian perspectives in these same texts.

This silence, too, must be taken in some circumstances as a knowing silence. In his article "Redeeming Beggary/Buggery in Michaelmas Term," Theodore Leinwand proposes that the play ends with Easy going on to future homosexual relationships: "Easy's final exit, without Thomasine (or the never-intended Susan), suggests his availability within an at least gentle homoerotic circuit" (62). Leinwand is, of course, aware of the scholarship that has already remarked on Middleton's associations with Puritans and his own Calvinist perspectives; he cites some of this scholarship in The City

Staged: Jacobean Comedy 1603-1613 (1986). 5 Furthermore, Leinwand is the editor of Michaelmas Term for the Oxford Middleton. Therefore, a conclusion that Easy may continue into homosexual relationships must be reconciled with Easy's apparent repentance in Act V, scene i:

Here's good deeds and bad deeds, the writings that keep my lands to me, and the bonds that gave it away from me. These, my good deeds, shall to more safety turn, And these, my bad, have their deserts and burn.

This repentance suggests that beggars and buggers may be redeemed, but not beggary/buggery, which "have their deserts and burn."

If Leinwand's reading is a distortion of Middleton's consideration of sodomy, it is based on his interpretation of Easy as a distinctly homosexual character. This is because, in Leinwand's view, 
Michaelmas Term stages a historical conjuncture at which no necessary, or wholly naturalized, relation between sodomy and stigma prevails. The play indicates that in some instances, homosocial relations in Jacobean London may have been founded upon, at the very least may not have been antipathetic to, homoeroticism.

[54]

There are several problems with this interpretation, including the question of whether Easy, a naive prodigal, is the kind of character that critics motivated by gay advocacy would want to advance. Bray is less optimistic than Leinwand; referring to the satires Microcynicon and The Black Book, he speaks of Middleton's "obvious bias and downright distortions" (38).

What is notable about these responses to Middleton's texts is that, although they are motivated by opposing ideologies-Leinwand by gay advocacy, Levin by his general dislike for readings emphasizing genderneither one can be said to have considered both Middleton's representations of homosexuality and his Calvinist perspectives. In the Renaissance, as Bray, Brown, and others have shown, the representations of homosexuality are rarely made without religious comment. This holds true for Middleton's representations.

The primary distinction of Middleton's representations is that most of his are made within the theatres, which were frequently, and with reason, charged with promoting sodomy. When Middleton presents the repentance of a sodomite, then, he answers two questions: how should a Calvinist dramatist respond to antitheatricalism (often Calvinist as well), especially when the charge against the theatre is that its use of cross-dressing boy actors promotes sodomy, and how should he respond to that sodomy itself? 
Middleton's answers to these questions may also tell us much about his sense of responsibility both to his vocation (how he sees himself as a dramatist), and to his associates; this view of Middleton is, I think, the broad value of this particular study.

Middleton's "bias" against sodomy (the conclusion of Bray's analysis) is not surprising given his Calvinist orthodoxy. In The Two Gates of Salvation, Middleton matches Genesis 6: 5, 6-about God's decision to judge the earth with a flood-to Matthew 15: 19, 20, which speaks of the wickedness of the human heart. In Genesis, "The Lord saw that the wickednesse of man, was great in the earth, and all the imaginations of the thoughts of his heart were onely evill continually" (D4v). In Matthew, "Out of the heart come evill thoughts, murders, adulteries, fornications, thefts, false testimonies, slanders, these are the things which defile the man" (E1r).

Middleton does not cite the Levitical and Pauline scriptures against same-sex sexual relations. But in Renaissance texts, sodomy could be considered a partial cause for Noah's flood because the male children of sexual unions between people and spirits were frequently believed to be sodomites (Bray 21-22). 6 What God saw before deciding to judge the earth was that "the sons of God saw the daughters of men that they were fair; and they took them wives of all which they chose" (Genesis 6:2). Who exactly were these "sons of God" is never finally settled-men or angels, and if angels, were they already fallen or was this their fall? ${ }^{7}$ 
Sir David Lindsay, Protestant Scotch dramatist and poet, believed they were children of Seth, Adam's third son, who mated with daughters of Cain. In Lindsay's First Buke of the Monarche (1552), the result was,

Than, as the peple did incres, Thay did abound in wickitnes, As holy Scripture dois rehers: Quhilk I abhor to putt in vers, Or tell with toung I am nocht abyll;

The suthe bene so abhominabyll,Quhow men and wemen schamefullye Abusit thame selfis vnnaturallye; Quhose foull abhominatioun And vncouthe fornicatioun

I thynk gret schame to puit in wryte. [lines 1229-1239]

While Lindsay does not mention sodomy (perhaps because the destruction of Sodom occurs later in Genesis than the Flood), his language is common to the language drawn from the Bible to discuss sodomy. For example, among those who will not inherit the kingdom of God in I Corinthians 6: 9 are "abusers of themselves with mankind," the King James Bible translation for the Greek arsenokoites, which is translated as "bouggerers" in the Geneva Bible and, commonly, as "homosexuals" or "sodomites" in modern translations. Lindsay writes of how men and women "abusit thame selfis vnnaturallye," a phrase which can combine both I Corinthians 6: 9 and Romans 1: 26-27, which speaks of how "women did change the natural use into that which is against nature: And likewise also the men, leaving the natural use of the woman, burned in their lust one toward another."

Sodomy is also frequently considered in the Renaissance a sin too shameful to be named (with reference to Ephesians 5:12) and an 
abomination (referring to Leviticus 18: 22 and 20: 13). All of this language appears in Lindsay's text-"Quhose foull abhominatioun/And vncouthe fornicatioun/ I thynk gret schame to putt in wryte"-and although The Monarche predates the Authorized Bible by sixty years, it shows the currency of the language used for discussing sodomy.

Even when he is almost naturalistic in presenting sodomy, Middleton still uses language drawn from the same Christian tradition. In his prose satire of the London underworld,The Black Book (1604), he offers a continuation of Thomas Nashe's Pierce Penniless. 8 Pierce Penniless appears in The Black Book, but rather than recording Penniless' further supplications to the devil, Lawrence Lucifer himself visits brothels and other underworld haunts to discover their enormities. Lucifer discovers a "nest of gallants" who

for the natural parts that are in them, are maintained by their drawnwork dames and their embroidered mistresses ... [and they] keep at every heel a man, beside a Frencin lacquey (a great boy with a beard) and an English page, which fills up the place of an ingle. [VIII, 21; emphasis added]

The gallants in The Black Book maintain dames and mistresses "for the natural parts that are in them." By implication of the contrast, therefore, their keeping of an English page to "fill up the place of an ingle" is for an unnatural sexual impulse. (An "ingle" is a male prostitute in Renaissance English; the word has various spellings.) These observations, furthermore, are made by the persona of Lawrence Lucifer. When Middleton matches 
Genesis 6: 5, 6 with Matthew 15: 19, 20, we may easily conclude that he would have considered sodomy a kind of fornication and the following of evil thoughts. ${ }^{9}$

Yet Middleton's Calvinism alone does not account for his portrayals of homosexuality. There is no approval nor allowance for sexual relations between men in his works, but his "damns" of sodomy are far fainter than can often be found in his age, especially in comparison to the common idea that sodomy forbodes imminent catastrophic divine judgement (Bray 27-32). In Michaelmas Term, Richard Easy is recovered from both his prodigality and his sexual relation with Shortyard; he also has his lands restored to him. Shortyard and Quomodo's other "spirit" Falselight are banished from England (perhaps, as a kind of exorcism, the only judgement that could be passed on spirits). Quomodo, who instigates the sexual relationship between Shortyard and Easy, is publicly humiliated at his own funeral, he is cuckolded, and he loses the property he stole from Easy; yet, the judge adds no further judicial penalty because "Thou art thine own affliction, Quomodo" (V. iii. 164). In contrast to all of this, Quomodo's wife Thomasine seems to get the worst treatment (because it is unmerited by her actions) in the conclusion; her blameless remarriage to Easy is voided when Quomodo is found to be alive after all.

There is even less explicit judgment against sodomy in The Roaring Girl. The prodigal Jack Dapper, who has "Roaring boys follow at's tail, 
fencers, and ningles" (III. iii. 66), receives Moll Cutpurse's assistance to escape from the sergeant taking him to debtor's prison. And Sir Beauteous Ganymede and Sir Thomas Long are not so much judged for sodomy (which is only implied, in any case) as they are subsumed into and by the main plot of the play. Of course, their marginalization in the play still represents authorial judgement on sodomy itself, but not to the extent that they are shown to suffer for it. The question then is that if sodomy could be considered a particularly malignant evil-and generally it was so considered-what explains Middleton's relatively mild treatment of it?

The answers must begin with specifying definitions in the manner generally found in recent studies by Gregory W. Bredbeck, Bruce R. Smith, Jonathan Goldberg, Alan Bray, and others involved in gay and lesbian studies. First of all, "sodomy" and "homosexuality" are not easily interchangeable synonyms for discussing the same subject. "Homosexuality" is an ontological term; a "homosexual" is a person whose orientation or preference sexually is for a person of his or her own sex. Today, homosexuality is considered a part of a person's state of being, sometimes considered the formative or dominant characteristic of the person's personality.

Of course, the word "homosexuality" dates from the 1890s. But even with the language then in circulation, there was apparently little notion in Renaissance England that one's personality might in some way stem from different sexualities. Instead, sodomy involves certain acts (not always 
necessarily anal intercourse), usually between men, but sometimes between men and women, and even acts of bestiality performed by either sex (Bray 14). A sodomite, then, is a person who commits those acts.

Sodomy was also one of the worst of the sins that could be considered debauchery. Besides sodomy, debauchery included drunkeness, fornication, gluttony, sloth, adultery, gambling, and the pursuits of any other sensual pleasures. Other acts of debauchery were considered causes for a person falling into sodomy; drunkeness, according to George Turbervile, and "pride, excess of diet, idleness, and contempt of the poor," according to Edward Coke (Bray 16). Thus, rather than being the desire of a group of people with a singular propensity, sodomy was anyone's potential depravity. Just after Paul enumerates the sins which could keep a person from inheriting the kingdom of God, including sodomy (Gk. arsenokoites), he recalls of the Corinthian Christians, "And such were some of you" (I

Corinthians 6: 11). John Calvin annotates the line:

We must not understand [Paul] to mean that all are wrapped up in the same bundle as if he attributes all these vices to each one of them. But he only wishes to point out that no-one is free from these evil things until he has been born again by the Spirit. For we must hold that human nature, speaking universally, contains the seed of all evils, but that some vices predominate and make themselves evident in some men, as the Lord brings the depravity of the flesh to view by its fruits. [Calvin's Commentaries 125]

Exhibiting a similar perspective, William Bradford, the governor of Plymouth colony, claims, "Sodomy and buggery (things fearful to name) have broke forth in this land" because of "our corrupt natures, which are so 
hardly bridled, subdued, and mortified" (Bray 17). In No Wit, No Help Like a Woman's, Weatherwise observes an effiminate gallant while he is courting the widow Goldenfleece: "A proper woman turn'd gallant! If the widow refuse me, I care not if I be a suitor to him. I have known those who have been as mad, and given half their living for a male companion" (II. i. 180-183). Bray concludes, "The temptation to debauchery, from which homosexuality was not clearly distinguished, was accepted as part of the common lot, be it never so abhorred" (16-17).

There is no wholly satisfactory language for negotiating the differing assumptions about homosexuality between the Renaissance and our world today. Richard Easy, for example, commits sodomy with no immediate qualms, but would it be appropriate to label him a homosexual or bisexual character? Apparently not, at least in part because "homosexual" and "bisexual" suggest character or personality traits that influence, but remain identifiable separately from, sexual activity. In other words, current psychological theories maintain that a homosexual's homosexuality is present regardless of the person's actual sexual behavior. For Richard Easy, however, when he quits committing sodomy and marries Thomasine, he quits being a sodomite. For the remainder of this study, when the word "homosexual" is used, its ontological connotations will not be intended; rather, it will be used to refer to characters like Jack Dapper whose sexual activity is noted to be with other males. By Renaissance concepts, they have acted on the potential for debauchery open to all humanity. 
The easy answer for Middleton's treatment of characters involved in homosexuality is that it concurs with his treatment of other debauchers and of debauchery in general. If Penitent, Gratiana, Sir Walter Whorehound, Theodorus Witgood, and the Courtesan can all experience God's grace, debauchers all, then Richard Easy's experience of grace is not unusual within Middleton's canon. Without considering the vexing Calvinist conflict between free will and election and damnation, Middleton claims that salvation is anyone's possibility: "The treason of the first Adam put the second to death, and the death of the second, quitted all the sonnes of the first" (The Two Gates B1v). And while observing the correspondence between leprosy and sinfulness in chapter two, I noted Middleton's annotation of Matthew 8: 2-4: "In this, Christ shews, that he abhorreth no sinner, that comes unto him, be he never so uncleane" (D2r).

Most of Middleton's homosexual characters do not receive grace. Yet among the debauchers who neither receive grace nor are shown to suffer for their doings, Sir Beauteous Ganymede and Sir Thomas Long (both of The Roaring Girl) offer no immediate or evident dangers to their social settings. In contrast to them are the Allwits, who intend to open a brothel and who are also unpunished for their debauchery. Although the portrayal of all these characters is satirical, the portrayal of the Allwits is more biting, and they represent greater dangers to their social setting.

Yet if theoretically sodomy is just one kind of debauchery among several kinds, if the temptation of sodomy is common, and if Middleton's 
view that "Christ abhorreth no sinner that comes unto him" is a common view (with salvation open to all), then the salvations, conversions, or repentances of homosexuals or sodomites are seldom recorded, whether in literary texts or in historical accounts in the Renaissance. Not so the conversions of other debauchers, from St. Augustine on down to Middleton's characters. This is not to suggest that there were no conversions or repentances of sodomites to record. Other possibilities are that their sins would have been noted by more general terminology (including "debauchery" itself), or that at this yet early date in gay studies, records of such religious experiences have not yet attracted attention. Whatever the reason may be, Middleton's practical consideration and literary portrayal of grace as it applies to those who commit sodomy appears rare for the Renaissance. 10

Practical is, of course, in the eye of the beholder. But Middleton does situate his considerations of grace in contexts including both the recorded practices of homosexuals and the commonly held beliefs of his society regarding sodomy. Sodomy in the representations of Renaissance English popular culture involves prodigality, the activities of gallants, transvestism, demonology, the activities of the Jacobean court, and the relationships of masters and servants. Sodomy also raises epistemological questions about sex and gender, the distinctions between what is natural and unnatural, and thus, questions about human nature itself. Everything Middleton portrays 
of homosexuals and sodomy can be examined with reference to other texts which consider or portray homosexuals in corresponding ways.

Furthermore, the verisimilitude Middleton's representations would have had with his Jacobean audience would have been heightened in The Roaring Girl by the appearance of the notorious female transvestite Moll Cutpurse as a character, and in at least one recorded instance, an appearance of Moll Cutpurse herself at a performance.

There are then three primary reasons for Middleton's interest in the subject of sodomy. The first is that sodomy serves in the Renaissance as a shorthand signifier for much that $\sin$ is and encompasses, the most debauching of debaucheries. Middleton does not portray sodomy as that extreme; his homosexuals have their equals (at least) in his other debauchers. But if Middleton can demonstrate on the stage how grace applies to homosexuality, then he argues for possibilities, and therefore probabilities, for grace beyond its usual representations. Grace becomes more than a merely theoretical construct.11

The second and third reasons for Middleton's interest in sodomy are tied together: there was homosexuality in London's theatrical community, and it received attention from the opponents of the theatre. The homosexuality of actors and the sodomy caused by the viewing of plays are emphasized by the antitheatrical writers of Middleton's time, becoming yet further decisive points, these writers suppose, in damning the stage. In the 
most succinct of these arguments, The Anatomy of Abuses (1583), Philip

Stubbes writes,

Marke the flocking and running to Theaters \& curtens, daylie and hourely, night and daye, tyme and tyde to see Playes and Enterludes, where such wanton gestures, such bawdie speaches, such laughing and fleering, such kissing and bussing, such clipping and culling, such winkinge and glancinge of wanton eyes, and the like is used, as is wonderfull to behold. Than these goodly pageants being done, every mate sorts to his mate, every one bringes another homeward of their way verye friendly, and in their secret conclaves (covertly) they play the Sodomits, or worse. And these be the fruits of Playes and Enterluds, for the most part. [L8r and v]

In The Overthrow of Stage-plays (1599), John Rainolds, an Oxford divine, argues for "the prohibition of men to put on women's raiment" because "men's natural corruption and viciousness is prone to monstrous sin against nature" (E2v). Earlier in the text, citing Socrates, Rainolds is more explicit about the issue:

When Critobulus kissed the sonne of Alcibiades, a beautifull boy, Socrates saide he had done amisse and very dangerously: because, as certaine spiders, if they doe but touch men onely with their mouth, they put them to wonderfull paine and make them madde: so beautifull boyes by kissing doe sting and powre secretly in a kinde of poyson, the poyson of incontinencie. [D1v]

Although Rainolds' text comes from letters he exchanged with the playwright William Gager in 1592, the publication date of 1599 corresponds, probably significantly, with the time when Middleton was briefly a student at Oxford.

Just over thirty years later, the most hyperbolic and hyperventilating of the theatre's opponents, William Prynne, continues the same argument in Histriomastix (1633). Laura Levine summarizes his argument: 
Ever graphic, William Prynne insists that dressing like women is always the necessary stimulant to homosexuality: the "male priests of Venus" always oblige their companions the "passive beastly sodomites of Florida" by going clad in women's clothing, the "better to elliciate, countenance, act and colour their unnaturall execrable uncleanesse." What this conviction implies of course is that the heterosexual titillation is pretext and the homosexual response what is "real." What this spectator is "really" attracted to when he looks at the stage is a man. [96]

Although our sympathies are not with the opponents of the theatre, their association of sodomy with the theatre is not merely a delusion. Homosexual liaisons are also noted by relatively objective observers (in comparison to the theatre's opponents) or by those who are even friendly to the theatre. Bray cites an account by Lucy Hutchinson, the wife of a Roundhead colonel, who notes some differences in the court of Charles from the court of James:

The face of the Court was much changed in the change of the king, for King Charles was temperate, chaste, and serious; so that the fools and bawds, mimics and catamites of the former court grew out of fashion and the nobility and courtiers, who did not quite abandon their debaucheries, yet so reverenced the king as to retire into corners to practice them. [Bray 55; emphasis added]

About this passage, Bray notes, "A 'mimic' was a burlesque actor; the usage is now obsolete but was current in the early seventeenth century and is here the only reading of the word that fits easily" (55).

Others who observe the association of sodomy and the theatre include Edward Guilpin, Ben Jonson, Thomas Dekker and Middleton himself. In Skialetheia (1598), a book of epigrams and satires, Guilpin writes of a gallant "Who is at every play, and every night/ Sups with his Ingles, who can well 
recite,/ Whatsoever rhymes are gracious" (Epigram 38, lines 11-13). In Jonson's Poetaster, Ovid's father worries about his son becoming a playwright: "What, shall I have my son a stager now, an ingle for players?" (qtd in Orgel, "Nobody" 19). Dekker dedicates his plague pamphlet News from Graves-End to "The now-onely-onely-Supper-maker to Enghles \& Plaiers-Boyes, Syr Nicholas Nemo, alias Nobody" (Plague Pamphlets 65). Middleton makes the connection in Father Hubbard's Tales, when a young gentleman is advised "if his humour so serve him, to call in at the Blackfriars, where he should see a nest of boys able to ravish a man" (VIII: 77). None of these are antitheatrical complaints against the stage; yet when they associate sodomy with the theatre, they do concur with Philip Stubbes, John Rainoldes, William Prynne, and others who oppose the theatre.

Both Michaelmas Term and The Roaring Girl need to be read with the charges of sodomy against the theatre in mind. For example, the homosexual characters inMichaelmas Term are not crossdressers, pointing to the existence of homoerotic activity independent of the theatre and its transvestite practices. Yet for some antitheatricalists, the theatre is the source of sodomy. The redemption of Easy also stands broadly for the possibilities of redemption Middleton suggests are available to others like him. These possibilities are never suggested by the antitheatricalists, so Michaelmas Term is a general counterpoint to their arguments.

In The Roaring Girl, however, Middleton (and Dekker) directly confronts the charges of the antitheatricalists by making the play exactly the 
kind they would most loathe-an exuberantly transvestite play, a veritable market of bawdry (in the market scenes), the playing of several sodomites, and, as noted earlier, the appearance of a woman on stage. Lest a reader miss the point, Middleton offers a dedicatory epistle to the first edition (1611), beginning, "To the Comic Play-readers: Venery and Laughter." The sexual pun on "venery" as both "good hunting" and "the practice or pursuit of sexual pleasure" (Mulholland's annotation) is used throughout the play, including when Laxton says he will act "like a puny at the inns of venery" (II. i. 140). The Roaring Girl is an argument for eros against the charges of antitheatricalists, but eros, as Middleton portrays it, within the blessing of marriage. The sodomites in The Roaring Girl are used to make this argument, and the play seems to be Middleton's effort to redeem the theatre from antitheatricalism. I will consider first the two early satires, Microcynicon and Father Hubbard's Tales, before examining the two plays in detail.

II. "Time was I loved Pyander well": The Wide Indication of Sodomy in Middleton's Satires

Middleton's earliest extant works, his juvenilia, are never praised, but sometimes the condemnation of the critics is immoderate. Their expectation seems to be that between the ages of sixteen and twenty, when Middleton wrote his first three published works, he should have already been a skillful writer. But these three works-The Wisdom of Solomon Paraphrased (1597), Microcynicon (1599), and The Ghost of Lucrece 
(1600)-might best be explained as writing projects or exercises, where the accomplishment is more in their completion than in their art.

Microcynicon resembles Joseph Hall's Virgidemiarum (1597-1598); both works start with a few stanzas of "Defiance to Envy" and an author's prologue (Barker 29). The body of Middleton's text consists of six satires of London character types, types he would return to throughout his later dramas: Insatiate Cron the miser is the precursor to Sir Bounteous Progress and Harry Dampit; Prodigal Zodon precedes Richard Follywit, Theodorus Witgood, and Richard Easy; Cheating Droone calls to mind a number of later cozeners, Quomodo among them. Of Middleton's early works, Microcynicon is closest in spirit to his mature artistic vision. If it does not achieve greatness, parts of it, as Richard Barker claims, "succeed in being readable and even lively" (29).

Satire V, of Ingling Pyander, differs from the other five satires by the involvement of the narrator in the situation he describes. It is unclear whether there is a single narrator or several in Microcynicon, but in the previous four satires, the narrator is an observer, not a participant. ${ }^{12}$ In Satire V, however, he offers himself as a victim of Ingling Pyander's wiles. His complaint is that he had fallen in love with Pyander, unaware that "she" is a cross-dressing boy. As in the other satires, Middleton makes the didactic point explicit ${ }^{13}$ :

Rash-headed cavaliers, learn to be wise;

And if you needs will do, do with advice; 
Tie not affection to each wanton smile, Lest doting fancy truest love beguile;

Trust not a painted puppet, as I have done,

Who far more doted than Pygmalion:

The streets are full of juggling parasites

With the true shape of virgins' counterfeits:

But if of force you must a hackney hire,

Be curious in your choice, the best will tire;

The best is bad, therefore hire none at all;

Better to go on foot than ride and fall.

"Hackney" is used here to refer to a prostitute as well as to a horse; to "ride and fall," therefore, is a double entendre. But ride whom? Taken in isolation, this passage refers generally to prostitution: The best hackney is bad, so hire none at all. But if the readers are to "trust not a painted puppet, as I have done," we know that the narrator has trusted Pyander.

This passage raises the sex and gender confusions associated with crossdressing and sodomy. A puppet, for example, is already an imitation of a gendered being, so does it matter if the puppet is painted? Furthermore, because puppets have no sex, we may recall how Puppet Dionysius answers the Puritan Busy's objection of transvestism in Jonson's Bartholomew Fair, "It will not hold against the puppets, for we have neither male nor female amongst us" (V. v. 92-94). Earlier when the narrator first reveals Pyander as the subject of his outrage, he reports,

Sometimes he jets it like a gentleman, Otherwhiles much like a wanton courtesan; But, truth to tell, a man or woman whether, I cannot say, she's excellent at either; But if report may certify a truth, She's neither of either, but a cheating youth. [23-28] 
In Bartholomew Fair, Puppet Dionysius concludes his argument by exposing himself, proving as well that he is neither of either, but not even a cheating youth.

The narrator's assertion that "The streets are full of juggling parasites/ With the true shape of virgins' counterfeits" (94-95) reiterates the epistemological problem. What, after all, is a "true shape of virgins' counterfeit"? The phrase has no literal meaning, only possibilities: The true shape of a counterfeit virgin might actually be a virgin, as in the true counterpart to that which is fake. It might be a prostitute, the true counterfeit of a virgin. The phrase must also include Pyander, a parasite with the true shape of a virgin's counterfeit.

While these confusions or ambiguities may inhere in the subjects of cross-dressing and sodomy, they are also motivated by the needs of the narrator. Unlike the other satires in Microcynicon, "Ingling Pyander" implicates its narrator, perhaps more so than even Pyander himself. Any confusion the narrator can raise about Pyander's sex or activities might also serve to diminish the reader's sense of his own culpability. But the narrator is not exonerated. Indeed, while the narrator considers Pyander's parentage, we quickly learn that he is the son of a prostitute that even the narrator has consorted with:

Old beldam hath a daughter or a son, True born or illegitimate, all's one; Issue she hath. The father? Ask you me? The house wide open stands, her lodging's free: Admit myself for recreation 
Sometimes did enter her possession, It argues not that I have been the man

That first kept revels in that mansion. [3-10]

However much the narrator may complain about his mistreatment from Pyander, the narrator himself is a debaucher. What the narrator argues against Pyander reverberates back on himself. 14

The equivalence of sodomy with other kinds of debauchery continues when this brothel the narrator has visited (the mansion) is named:

The tenement hath oft been bought and sold:

'Tis rotten now, earth to earth, dust to dust,

Sodom's on fire, and consume it must. [12-14]

I have noted earlier that sodomy in Renaissance usage does not refer exclusively to male-to-male sexual activity (although that is its usual reference). Bray cites several uses of "Sodom" and its cognates that must be taken as having heterosexual references $(14,18)$. Notable are the brothels Sodom and Little Sodom of Salisbury Court during the Restoration, remarked upon by John Wilmot and John Dryden. More contemporary to Middleton's work is the use of "sodomitess" as an annotation for "whore" in the margin of the Authorized translation of Deuteronomy 23: 17. As long as sodomy could be thought a heterosexual activity, then a reader could take Middleton's narrator (and not only Ingling Pyander) as a sodomite because he has visited Sodom, the brothel.

If debauchery leads to debauchery from worse to worst, then we may also conclude the narrator is a sodomite of the usual sort. The narrator describes his initial encounter with Pyander in a straightforward manner: 
Walking the city, as my wonted use, There was I subject to this foul abuse: Troubled with many thoughts, pacing along, It was my chance to shoulder in a throng; Thrust to the channel I was, but crowding her, I spied Pyander in a nymph's attire:

No nymph more fair than did Pyander seem, Had not Pyander then Pyander been; No lady with a fairer face more graced, But that Pyander's self himself defaced; Never was boy so pleasing to the heart As was Pyander for a woman's part.

The result of the narrator's quick infatuation soon follows:

So far entangled was my soul by love, That force perforce I must Pyander prove:

The issue of which proof did testify Ingling Pyander's damned villainy. I loved indeed, and, to my mickle cost, I loved Pyander, so my labour lost:

Fair words I had, for store of coin I gave, But not enjoyed the fruit I thought to have. [74-81]

The narrator does not indicate whether his sexual union with Pyander occurred just after they met in the street, or how long it was until "So far entangled was my soul by love,/ That force perforce I must Pyander prove" (74-75). But however long this took, the narrator would have us believe that he always took Pyander for a woman.

This is called into question by his other comments, including one cited earlier: "Sometimes he jets it like a gentleman,/ Otherwhiles much like a wanton courtesan" (23-24). When or how the narrator comes to know Pyander jetting it like a gentleman is uncertain, but the knowledge itself suggests either that the narrator knew this before their sexual union, or that he maintained some contact with Pyander even after not enjoying the fruit 
he thought to have (81). This problem of time also arises when the narrator explains why he is telling about Pyander at all:

What, shall I cloak sin with a coward fear, And suffer not Pyander's sin appear? I will, I will. Your reason? Why, I'll tell, Because time was I loved Pyander well;

True love indeed will hate love's black defame, So loathes my soul to seek Pyander's shame. Oh, but I feel the worm of conscience sting, And summons me upon my soul to bring, Sinful Pyander into view,

There to receive the shame that will ensue! [37-46]

Expressions of "true love" between men are common enough in

Renaissance texts, and they do not necessarily denote sexual desire.

However, if the narrator's explanation of the development of his relationship is to be believed-that he took Pyander for a woman until "force perforce [he] must Pyander prove" (75), then how is the reader to believe that "time was [he] loved Pyander well" (40)?

A few lines earlier, the narrator notes the physical points of attraction Pyander had for him:

Whose rolling eye sets gazers' hearts on fire, Whose cherry lip, black brow, and smiles procure

Lust-burning buzzards to the tempting lure. [34-36]

If there had been a time when the narrator loved Pyander well, we are never shown when it was. There is no in-between period from when the narrator is himself a lust-burning buzzard to his creating a cloak for his own sin (or perhaps a closet?) while outing Pyander; i. e. there is no time when the narrator loved Pyander well. 
The critical interest so far shown in Satire V of Microcynicon has been focussed on Ingling Pyander rather than on his lover, the narrator. But do the narrator's contradictions invalidate his conclusion ("If of force you must a hackney hire ..." quoted above)? The narrator uses religious language throughout the text, speaking of sinfulness, shame, and the sting of the worm of conscience. Most telling, however, is the linking of Old Testament language to pre-Christian myth. Recall the language when the narrator tells of the brothel he used to visit:

"Tis rotten now, earth to earth, dust to dust, Sodom's on fire, and consume it must; And wanting second reparations, Pluto hath seized the poor reversions. [13-16]

A few lines later, the narrator describes London as "Troynovant, that alladmired town,/ Where thousands still do travel up and down,/ Of beauty's counterfeits" (29-31). The moral import of this satire comes from within Sodom or before Christ, as "if of force [one] must a hackney hire" (emphasis added). This satire offers no place outside of the state of original sin from which to moralize. That is why the conclusion-"Better to go on foot than ride and fall" (99)-appears like a word of advice rather than a proclamation. To go outside of this state requires a grace which Middleton considers later, in Michaelmas Term and The Roaring Girl, in relation to sodomy.

The next significant mention of homoerotic desire in Middleton's works occurs in Father Hubbard's Tales; or, The Ant and the Nightingale (1604). The text presents the misadventures of a country youth whose father 
has died and who is wasting his inheritance in London, "metamorphosed," significantly, "into the shape of a French puppet" (VIII: 68). The youth is accompanied by several of his tenants, and the Ant narrates the tale in the persona of a ploughman. They fall into the company of an Irish lawyer who "when in sight of us, he embraced our young gentleman (I think, for a fool), and gave him many riotous instructions how to carry himself, which he was prompter to take than the other to put into him" (VIII: 77). The lawyer's advice includes how to meet the gallants who spend the most money and what taverns to dine at:

Then after dinner he must venture beyond sea, that is, in a choice pair of noblemen's oars, to the Bankside, where he must sit out the breaking up of a comedy, or the first cut of a tragedy; or rather, if his humour so serve him, to call in at the Blackfriars, where he should see a nest of boys able to ravish a man. This said, our young goose-cap, who was ready to embrace such counsel, thanked him for his fatherly admonitions, as he termed them, and told him again that he should not find him with the breach of any of them, swearing and protesting he would keep all those better than the ten commandments. [VIII: 77-78; emphasis added]

Stephen Orgel cites the italicized portion of this and Ben Jonson's Poetaster ("Shall I have my son a stager now, an ingle for players?") to note both dramatists' acknowledgement of homosexual prostitution associated with the theatre. He introduces these citations by claiming, "The attitude implied in the charge tends to be, surprisingly, liberal and permissive" ("Nobody" 19). Relative to the usual discourses on the subject of sodomy in Middleton's and Jonson's time, this may be true; neither writer exhibits a high degree of anxiety about sodomites. But if their attitudes may be labelled 
"liberal" (which is likely to be misleading), they cannot accurately be called "permissive" because rather than denouncing sodomy, they satirize it.15 This portion of the Ant's tale should not be read out of the context of the conclusion, when the gallant, having lost all his money, is now "the true picture of the prodigal" (VIII: 84). The lawyer's advice leads to no good end.

Middleton also makes his point by punning on the word "breach." "To breach," in its primary meaning for this passage, is to break, as in the breaking of the commandments. However, "breach" is also a pun for "breech," which can mean both a person's rear end and an article of clothing to cover the loins. In the Geneva Bible, Adam and Eve "sewed figtre leaves together, and made them selves breeches" (Genesis 3: 7); this translation caused the Geneva Bible to be known as the "Breeches Bible." "Breeches" is also an early form for the Southern colloquialism "britches," for trousers. Thus, if the gallant will not be found with the breach of any of the lawyer's fatherly admonitions, then he will be found in someone's breech.

Immediately after leaving the lawyer's company, the young gallant was "of a sudden ... encountered by a most glorious-spangled gallant, which we took at first to have been some upstart tailor, because he measured all his body with a salutation, from the flow of the doublet to the fall of the breeches" (VIII: 78). This tailor is the young gallant's companion through the rest of his dissolution. Keeping the lawyer's admonitions will indeed mean the young gallant keeps them better then the ten commandments, 
and his fall by breaching the commandments is caused in part by the fall of his breeches.

Further problems with the tone of this text (liberal and permissive?) arise when we consider the relationship of the author himself to what he writes here and in Microcynicon. Why, for example, does Middleton specifically mention the boys at the Blackfriars? Most of his city comedies were performed by the Paul's boys. At the Blackfriars were the Children of the Revels, who performed Your Five Gallants and A Trick to Catch the Old One (1606). 16 We cannot yet determine whether the Children of the Revels were rivals to Middleton's personal interests (although they were rivals to the Paul's boys), or whether he was already working with them in 1604 when he wrote Father Hubbard's Tales. Even if he were working with the Blackfriars boys, was he satisfied with their performances? Jonson, we may recall, criticizes the actors of his plays. Shakespeare also complains of the "aery of children, little eyases" who perform plays (Hamlet II. ii. 339). Is Middleton's reference to the nest of boys at the Blackfriars able to ravish a man an insult, a joke, an attempt at retribution, or a simple statement of what Middleton believes about them?

If Middleton is reporting what he believes to be true about the Blackfriars boys, that hardly solves the interpretive problem because the next question is whose homoerotic desire is being remarked. First it is the lawyer's in the text. "Ravish" complicates this question because the reader 
does not know who would be ravishing (to) whom. If "ravish" here means rape, then this expresses the homoerotic desire of the nest of boys, who are "able to ravish a man." But "ravish" also means to delight or fill with ecstacy; by this meaning the homoerotic desire is of the viewers, the lawyer and the young gallant, delighted by gazing on the boys. ${ }^{17}$

The problem of deciding whose homoeroticism is being noted within the text is matched by the problem of situating Middleton's comments within the social context. If Middleton is reporting, do his words express a commonly-held judgement about the Blackfriars boys, his opinion of what constitutes erotic desires for sodomites, his own homoerotic desires, or something else? Contemporary records do show that the Blackfriars boys had a reputation for their dissolute ways. Leinwand notes a 1601 Star Chamber case in which

Henry Clifton, a Norfolk gentleman residing in London, complained to the Queen that his thirteen-year-old son and sole heir, Thomas, had been violently carried to the "play howse in the Blackfryers" where he was "committed ... amongste a companie of lewd \& dissolute mercenary players." What especially exercised Henry Clifton was that "yt was not fitt that a gentleman of his sorte should have his sonne \& heire ... to be soe basely vsed." Indirect evidence suggests that the Star Chamber justices agreed with Clifton, not on the general issue of impressing boys for playing and profit, but insofar as the "taking vp of gentlemens children against theire wills and to ymploy them for players" was worthy of censure. ["Redeeming" 60]

But the question of how to read Middleton's comment remains and can be expanded to include Microcynicon: even if we distinguish between Middleton and his Microcynicon narrator (whose voice is older than 
Middleton's nineteen years), yet Middleton must have believed the voice of a sodomite was a voice he had access to, if only imaginatively. The answer is two-fold, divided between his works and the social context he worked in.

If a critic were to argue that Middleton was either a homosexual or a sodomite, the argument currently would have to be based on the assumption (albeit a strong assumption) that such knowledge as Middleton exhibits on the subjects of sodomy or homoeroticism could only be had by personal homoerotic experience. This would be similar to using Shakespeare's sonnets to conclude he had homosexual experiences. The difference, however, is Middleton's moralizing impulse. Even in Microcynicon and the conclusion of the Ant's tale, there is enough evidence to infer his basic opposition to sodomy. His opposition does not prohibit the conclusion that he had homoerotic desires or sodomitical relationships, but we do not have the kind of independent evidence that exists for Christopher Marlowe's or Sir Francis Bacon's homosexuality.

On the other hand, as far as a segment of the religious community would be concerned, Middleton could easily have been thought guilty of sodomy by association-with the theatre. In June 1599, by order of the Bishop of London, copies of Microcynicon were gathered up and burned along with Marston's Scourge of Villainy and Edward Guilpin's Skialethia, which also satirize homosexuality. Bray suggests that the ecclesiastical authorities suspected the authors "with reason of a too lively interest in the very vices they claimed to be censuring" (33). The interest which these 
satires could have provoked is similar to the interest in vice which the stage was said to provoke. When The Roaring Girl went from the stage to print, the venery and laughter offered to the comic play-readers is essentially the same as the venery and laughter offered the play-goer. The difference is the performance, but the text itself is "good to keep you in an afternoon from dice, at home in your chambers; and for venery, you shall find enough for sixpence, but well couched an you mark it" ("Epistle" 11-14).

A description like that seems almost designed to provoke the antitheatricalists. Likewise the notion that those men who gaze upon the Blackfriars boys may be ravished by the sight of them. The complaint against sodomy in the antitheatrical texts is precisely that boys in women's dress stir up lusts for the boys themselves. Middleton is caught in a bind, against sodomy but not exactly against the sodomites insofar as his interests include an acceptance of their presence. He also reveals the familiar Pauline tension between loving the sinner and hating the sin. As we turn to the plays, I think we will find that in relation to sodomy, Middleton deploys the offer of grace strategically-salvation or repentance for his homosexual characters is his argument as well for the sanctity of the theatre.

III. Undoing Sodomy: Richard Easy's Redemption in Michaelmas Term One of the interpretive commonplaces in the criticism of Michaelmas Term is that Richard Easy is innocent in the events that lead to his downfall. Typical comments are that he is "a dumb beast led to financial slaughter" (Yachnin, "Social Competition" 95), that he is "Quomodo's gentle 
gull" (Leinwand, The City Staged 9), that he "falls into his predicament partly because he is foolish but mainly because he is innocent and does not understand the ways of the world" (Baines 43), and that he "was an innocent abroad" (Heinemann 91). On the other hand, many studies of the play include some acknowledgment that Michaelmas Term fits in the prodigal son play tradition.

Michaelmas Term, like A Trick to Catch the Old One, reworks of the prodigal son parable: Richard Easy arrives in London from Essex, a country gentlemen newly possessed of his inheritance. Quomodo, a London textile merchant, and Shortyard, his accomplice, scheme to dupe Easy out of his property. Quomodo instructs Shortyard to disguise himself as a London citizen (alias Master Blastfield) and to insinuate himself into Easy's confidence. Then once Easy and Shortyard have spent up their ready cash by gambling, they would approach Quomodo for a loan. Shortyard requests the loan, and offers Easy as his cosigner. But rather than giving them money, Quomodo gives them worthless cloth at a highly inflated price. This exchange is witnessed by Quomodo's wife, Thomasine, who figures prominently in the play's denouement. Thereafter, "Blastfield" disappears, and Shortyard disguises himself, first as a sergeant to arrest Easy for payment of the loan, then as a citizen who would offer to help Easy if only it were feasible. At the beginning of Act IV, Quomodo takes possession of Easy's property. The parallels between Easy and his Biblical prodigal son precedent 
include their travels from home, their debauchery, their loss of their inheritances, and their restorations.

As noted earlier, criticism of Michaelmas Term has consistently overlooked or ignored the two features of its language which are central to this study-first, Middleton's use of sodomitical punning, discourse, and reference, and second, the religious language which establishes the moral perspective he would seem to have on his characters' actions. These are not entirely discrete categories of language; words may resonate religiously and also be suggestive of sodomy. Easy's prodigality itself, for example, cannot be dismissed from religious consideration simply because it conforms to the generic conventions of prodigal son plays; the genre itself has religious roots. Besides Easy, Middleton's other prodigals include Prodigal Zodon in Microcynicon, the gallant of Father Hubbard's Tales, Follywit, Witgood, and in Michaelmas Term, Lethe, the Country Wench, and her father.

While searching for his daughter, the Wench's father recalls his own dissolute youth in London:

Woe worth th'infected cause that makes me visit This man-devouring city, where I spent My unshapen youth, to be my age's curse, And surfeited away my name and state In swinish riots, that now, being sober, I do awake a beggar. [II. ii. 20-25]

"Swinish riots" recalls the original prodigal's fight with the pigs for food (Luke 15: 15-16), firmly linking the prodigality in this play with the audience's understanding of Biblical precedent. ${ }^{18}$ Easy is reliving the 
experiences of Country Wench's father. He too is visiting the city, from Essex. He too is "surfeiting" away his estate in a dice game even before Shortyard begins to draw him into Quomodo's confidence plot (II. i. 1-30). Where Easy is going, others have been.

The naiveté the critics note as a sign of Easy's innocence-"a dumb beast," a "gentle gull"-has support in Shortyard's evaluation of his defeat:

But for Easy, Only good confidence did make him foolish, And not the lack of sense, that was not it;

'Tis worldly craft beats down a scholar's wit. [IV. iii. 14-17]

"Good confidence" can refer both to Shortyard's successful confidence game and to Easy's overly-expansive faith in the goodness of people. Easy's "good confidence" corresponds with other observations of his malleability. Cockstone speaks of him as a "fair free-breasted gentleman, somewhat too open ... he is yet fresh and wants the city powdering" (I. i. 53-56). Quomodo also describes him as "fresh and free" (I. i. 117). Easy himself makes the extreme description of his character-as a cipher. While searching for Blastfield (Shortyard), he claims, "Methinks I have no being without his company" (III. ii. 6).

These characterizations of Easy's naiveté that the critics read as signs of his innocence could, however, just as well signify the opposite conclusion: that Easy is culpable, because he is gullible. Easy's openness, his freshness, and his lack of being corresponds to the "unshapenness" of the Wench's father's prodigal youth, his "age's curse" (II. ii. 22). Roger Holdsworth 
identifies "doubleness of identity" as, for Middleton, "the primary symptom of man's fallen nature" ("Revenger's Tragedy as a Middleton Play" 101); unshapenness is perhaps even more nefarious because it is even less determinate than doubleness. 19 Easy is most "free" when Quomodo has finally gulled him of his inheritance and discharged the claims against him: "Why, then Master Easy, y'are a free man, sir; you may deal in what you please, and go whither you will" (IV. i. 49-50). After Easy has married Thomasine and recovered his property, he indicates that his former activities were follies: "My joys exceed;/ Man is ne'er healthful till his follies bleed"(V. i. 14-15).

The claim that Easy's naiveté should be taken as a sign of his sinfulness can also be supported by considering two punning uses of "grace." The pun combines grace as an attribute of gentle refinement with grace as a state of being in divine favor. When Easy states that Master Blastfield (Shortyard) "might keep company with any lord for his grace," Shortyard's Boy responds in an aside, "Ay, with any lord that were past it" (III. ii. 12-14). Later, Shortyard himself tells Easy, "If you had any grace in you, you would be ashamed to look us i'th'face" (IV. i. 12-13). Divine grace, in this instance, would be operative if Easy had a sense of shame; a person would need to know his sinfulness before knowing his salvation. Easy's naiveté, then, is a mark of his sinfulness, lack of grace, and lack of shame-easy to dupe because of his blindness to anything that is done wrong by him or to him. ${ }^{20}$ 
If Easy's prodigality and lack of grace are enough already to establish the Christian implications of his situation-that he is in need of redemption, then some of the same language just examined also indicates his susceptibility to sodomy. As noted, prodigality in Father Hubbard's Tales leads the young gallant to the ravishing Blackfriars boys and the tailor who drops his breeches. Easy's freshness and openness also indicate his availability to sodomy; he is easy to dupe and to seduce sodomitically.

Our reading of this linkage of cozenage and sodomy which pervades the text should be informed by the common Renaissance linkage of sodomy and treachery. For example, the "bedfellow" relationship between Easy and Shortyard is often noted as behavior common to Renaissance friendship. Indeed friendships between men were generally more physically and emotionally intimate in Renaissance England than in late twentieth century America. Men who were friends would share beds, sometimes kiss, and declare their love for one another, all without any necessary implications of homoerotic desire. In some instances, sharing a bed was even just a matter of economy, as when servants shared beds to save space in a household.21 However, when sodomy did occur, at least part of the anxiety about it must have been due to the resemblance it had to common activity and its theoretical status as a temptation anyone could have. Bray notes that sodomy's "shadow was never far from the flower-strewn world of Elizabethan friendship and it could never wholly be distinguished from it" 
("Homosexuality" 56-57). Sodomy, then, was often considered or linked with treachery, and what treachery (and fraud) requires is resemblance with wicked intent. Sir Edward Coke, a seventeenth century legal scholar, claims sodomy is "crimen laesae majestatis, a sin horrible, committed against the King; and this is either against the King Celestial or Terrestial in three manners: by heresy, by buggery, by sodomy" (Bray, Homosexuality 20). ${ }^{22}$ As Bray notes, heresy, sodomy, and treason were all part of the charges Richard Baines raised against Christopher Marlowe (20).

The relationship between Easy and Shortyard is not the only one with homoerotic overtones. On the one hand, Quomodo desires Shortyard, but then he deputes Shortyard to express his desire both for Easy and for his lands. As for his desire for Shortyard, and Shortyard's desire to assist him, in Act I, scene i, Quomodo addresses him before revealing how to gull Easy:

But now to thee, my true and secret Shortyard, Whom I dare trust e'en with my wife; Thou ne'er didst mistress harm, but master good; There are too few of thy name gentlemem, And that we feel, but citizens in abundance. I have a task for thee, my pregnant spirit, To exercise thy pointed wits upon.

Shortyard: Give it me, for I thirst. [I. i. 85-92]

Why is Shortyard trustworthy around Quomodo's wife? Apparently because he has no intentions towards her; he is Quomodo's sexual subordinate, his "pregnant spirit." But, on the other hand, Shortyard does his master good, probably sodomitically, "and that we feel," when he has something to exercise his "pointed" wits upon. But, yet again, Shortyard 
may be Quomodo's phallus, a surrogate or not, of course as trustworthy with Quomodo's wife as Quomodo himself would be, doing her no harm, but doing the master good. This last reading works also with Shortyard as Quomodo's "spirit," his semen. This passage takes the reader into the same sexual confusion and contradiction that signifies sodomy in the satires.

The confusion itself is signified by the names of these two characters. Quomodo's full name is Ephestian Quomodo. Historically, Hephaestion was the second-in-command to Alexander the Great and his lover; when Hephaestion died, Alexander gave him a famously extravagant funeral. Critics usually refer Quomodo's fake funeral to the precedent of Volpone's fake funeral, but the historical precedent of Hephaestion's funeral may add further irony to the insincerity of Quomodo's mourners. "Quomodo" itself is the Latin interrogative for "how," which can be asked of both the process of gulling and the sexual technique of sodomy, the subjects of confusion. ${ }^{23}$ As will be noted, Quomodo explains how both are done.

Shortyard's name refers both to his potency and his usefulness in gulling. "Yard" was a Renaissance vulgarity for "penis;" his short yard, therefore, further explains why he "ne'er didst mistress harm." A short yard is also a fraudulent measuring-stick, particularly apropos for Quomodo's occupation as a textile merchant.

The target of Quomodo's plotting, Easy's lands, is revealed in such a way as to make this desire also appear sexual. Quomodo remarks: 
My journey was toward Essex-

Shortyard: Most true.

Quomodo: Where I have seen what I desire.

Shortyard: A woman?

Quomodo: Puh, a woman! Yet beneath her,

That which she often treads on, yet commands her.

[I. i. 97-100]

Quomodo's speech does not end here. However, if, in performance,

Quomodo were to pause here, perhaps to allow an expectant look from

Shortyard, then Quomodo's misogynistic expression could lead the audience to suppose that Quomodo is about to name a partially subordinate malebeneath a woman, sexually submissive, yet in command over her. Indeed, this would be close to the homoerotic sexual status of a boy actor. Yet Quomodo names neither woman nor man, but "Land, fair neat land" (I. i. 101), the end of the above speech.

The sexual inference remains valid, however, because in Easy's case, the land is the man. Good studies of the issues of land ownership and class structure in Michaelmas Term have been done, particularly Gail Kern Paster's article "Quomodo, Sir Giles, and Triangular Desire: Social Aspiration in Middleton and Massinger" and Paul Yachnin's "Social Competition in Middleton's Michaelmas Term," and their conclusions need not be rehearsed here. The main point for this argument follows from what has already been noted: Easy's progressive "unshapenness" or "freedom" corresponds to the loss of his lands and his sexual undoing; his repentance and recovery of being is accompanied by the recovery of his land and marriage to Thomasine. Lands and women, then, have for Quomodo sexual and financial values for which the one supposedly quits the other: 
There are means and ways enow to hook in gentry, Besides our deadly enmity, which thus stands:

They're busy 'bout our wives, we 'bout their lands. [I. i. 105-107]

The human anatomy, particularly the female, is often referred to bawdily as land. Donne puns on America and Newfoundland in "Elegy 19: To His Mistress Going to Bed": "Licence my roving hands, and let them go/ Before, behind, between, above, below./ O my America, my new found land" (25-27). In Romeo and Juliet, Mercutio refers to Rosaline's "quivering thigh,/ And the demesnes [regions] that there adjacent lie" (II. i. 20-21). In chapter two, we observed references to women as deer parks in both Venus and Adonis and A Mad World, My Masters.

Quomodo, however, reverses the reference-not the body as land, but the land as a body: "Oh, that sweet, neat, comely, proper, delicate parcel of land, like a fine gentlewoman i'th' waist, not so great as pretty, pretty" (II. iii. 82-84). Later, when Quomodo plots to fake his own death, his reason is, "I am as jealous of this land as of my wife, to know what would become of it after my decease" (IV. i. 110-112). So, if on the one hand, the land can be possessed as a female body, and, on the other hand, the land is the man (Easy), then to seduce Easy as if he were a woman is to take possession of his land. This is precisely what will happen.

Having stated his intentions to Shortyard, Quomodo next identifies Easy as their target, and instructs Shortyard on how to gull/seduce him:

Observe, take surely note of him, he's fresh and free; Shift thyself speedily into the shape of gallantry; I'll swell thy purse with angels. 
Keep foot by foot with him, out-dare his expenses,

Flatter, dice, and brothel to him;

Give him a sweet taste of sensuality;

Train him to every wasteful sin, that he

May quickly need health, but especially money;

Ravish him with a dame or two, be his bawd for once,

I'll be thine forever;

Drink drunk with him, creep into bed to him,

Kiss him and undo him, my sweet spirit.

[I. i. 117-128]

Much of this Shortyard is shown doing. In Act II, scene $i$, he shifts speedily into the shape of the gallant Master Blastfield, an appropriate name that of course passes by Easy. Then, it is by "keeping foot by foot" with Easy and "out-daring his expenses" in a dice game that Shortyard is able to connive him into dealing with Quomodo. When Easy declares himself broke at the game, Shortyard reproves him:

Sir, you shall not give out so meanly of yourself in my company for a million. Make such privy to your disgrace? You're a gentleman of fair fortunes; keep me your reputation. Set 'em all; there's crowns for you. [II. i. 31-34]

In Act III, scene i, Shortyard and Easy try to make passes at the Country Wench in Lethe's presence, Shortyard acting as Easy's procurer (III. i. 152-176), or "being his bawd for once." This scene suggests before the play's denouement that Easy's sexual activities are not exclusively homoerotic. The final step in the rake's progress, then, is his undoing.

"Undo" and its cognates, oft-repeated words in Michaelmas Term, neatly conflate the financial and sexual intrigues of the main plot. "To undo" has three pertinent meanings for this reading: to ruin a person financially, to ruin a person by seduction, and, most prominently after Act IV, scene i, to reverse the effect of an action. From Easy's initial meeting 
with Shortyard (in the guise of Master Blastfield), his openness to the first two kinds of undoing is notable:

Shortyard: An Essex gentleman, sir?

Easy: An unfortunate one, sir.

Shortyard: I'm bold to salute you, sir. You know not Master Alsup there?

Easy: Oh, entirely well.

Shortyard: Indeed, sir?

Easy: He's second to my bosom.

Shortyard: I'll give you that comfort then, sir, you must not want money as long as you are in town, sir. [II. i. 5-13]

Of course, Easy cannot possibly know Master Alsup because Shortyard, not having been to Essex, makes him up. Levin annotates Alsup, "all-sup, suggesting his hospitality." That is certainly one of the meanings of his name; feigned hospitality helps establish Easy's confidence in Quomodo. However, the name also suggests "all's up," adding financial ruin (as in "all's up" at a dice game) and the bawdy phallic meaning. What exactly, then, is second to Easy's bosom, especially when he lies about knowing Master Alsup? Easy is caught by Shortyard from the first words they speak, mostly because he hardly needs persuading to sodomy. His willingness is evident ("He's second to my bosom") before Shortyard offers "to give [him] that comfort then."

The fact that Easy and Shortyard are sharing a bed quickly becomes common knowledge to the other characters in the play. When they first visit Quomodo's shop to request a loan, Shortyard addresses Easy as "good sweet bedfellow" (II. iii. 136). Quomodo takes up the reference in the same scene when he inquires of Shortyard, "What do they call your bedfellow's 
name?" (304). (Quomodo is, of course, feigning not knowing Easy's name.) In Act III, scene iv, Shortyard disguises himself as a sergeant to arrest Easy in demand for payment of his debt to Quomodo; Easy requests time to find Master Blastfield (Shortyard) whose promissory note he cosigned. Easy claims, "Why, we lie together, man, there's the jest on't" (98).

Then in Act III, scene v, Shortyard disguises himself as a wealthy citizen who offers Easy bail until they can find Blastfield. Easy inquires of Rearage and the other gallants, with whom he had earlier been playing dice, whether they have seen Blastfield. Rearage responds, "I wonder you should miss on't lately; you're his bedfellow" (III. v. 45). Easy answers, "I lay alone tonight, i'faith" (46). When they are finally unable to find "Blastfield," the link between undoing, sodomy, and sharing a bed is reiterated:

Shortyard [as a London citizen]: What, have you found him yet? Neither? What's to be done now? I'll venture my body no further for any gentleman's pleasure; I know not how soon I may be call'd upon, and now to overheat myself-

Easy: I'm undone!

Shortyard: This is you that slept with him! You can make fools of us; but I'll turn you over to Quomodo for't. [III. v. 58-64; emphases added]

The scene ends with Shortyard declaring, "Though I love gentlemen well, I do not mean to be undone for 'em" (68-69), echoing the narrator's "Time was I loved Pyander well" in Microcynicon, but with even less credibility.

Perhaps one reason that most of the criticism of Michaelmas Term emphasizes the financial and legal intrigues to the exclusion of its homosexual intrigues is that the main action is reasonably focused on what 
could have been presented in detail on the Jacobean stage, the financial intrigue more than the sexual. A question can be raised, however, about what exactly is Michaelmas Term dramatizing: fraud presented as a sodomitical act, or sodomy presented as fraudulent behavior?

Throughout the extended gulling scene, Act II, scene iii, fraud and sodomy are inseparable and pervasive, with several references to bedfellows and undoing. However, the development of the gulling-the beginning, the bait-and-switch, and the conclusion-are the key moments where sodomitical language appears. As Shortyard performs the role of Blastfield, he first introduces Easy to Quomodo as, "a kind gentleman, a very inward of mine" (II. iii. 101-102). This follows Easy's stated admiration (in their previous scene) for Shortyard's "carriage" (his physical bearing), and Shortyard's invitation to Easy, "I beseech you, I give my friends leave to be inward with me" (II. i. 160-163). This language can function in the intimate friendship discourses noted earlier, exclusive of its sodomitical implications. However, Shortyard's invitation comes in the first scene in which Easy and Blastfield/Shortyard meet, hardly time enough for Easy to distinguish the terms of their relationship. The meaning of "inward" is destabilized by Shortyard's linkage of the term to Easy's comment on his physical attractiveness. Easy may be inward with Shortyard, and thereby becomes an inward of Shortyard's ("a very inward of mine").

A few moments after their introduction, Quomodo feigns his inability to supply Blastfield with funds, and suggests that he borrow money from 
Easy. Shortyard/Blastfield responds in language that emphasizes his sexual relationship with Easy and that again suggests Quomodo's own homosexual tendencies:

Shortyard: Why, Master Quomodo, what a fruitless motion have you put forth! You might well assure yourself this gentleman had it not, if I wanted it. Why, our purses are brothers; we desire but equal fortunes; in a word, w'are man and wife; they can but lie together, and so do we.

Easy: As near as can be, i'faith. [II. iii. 152-157]

Men lying together like husbands and wives is the focus of the Levitical injunction against sodomy: "If a man also lie with mankind, as he lieth with a woman, both of them have committea an abomination" (Leviticus 20: 13). Here Easy and Shortyard do as much as a man and wife-"they can but lie together, and so do we"-with Easy emphasizing the physical similarity-"as near as can be, i'faith." The bawdiness of Easy and Shortyard lying together as near as can be is obvious, but we should further note that Quomodo's "fruitless motion" which he "put forth" can also refer to the lack of procreative capability in sodomy.

During the bait-and-switch, Quomodo's other assistant, Falselight, disguised as a porter, is given the task of transporting the worthless cloth they mean to foist on Easy instead of money for the loan. Referring to Falselight, Easy observes,

How the poor rascal's all in a froth! Shortyard: Push, they're ordain'd to sweat for gentlemen; Porters' backs and women's bellies bear up the world.

Easy: 'Tis true, i'faith; they bear men and money, and that's the world. [II. iii. 318-322; emphasis added] 
Easy has skewed both his pronoun reference-who are "they"?-and his parallelism-do porters' backs bear men and women's bellies money? This is suggested in the literal sense of his words. This dialogue could be considered gratuitous; it has no part in the development of the cozenage. But Middleton does not let his audience lose sight of the sodomy in the cozenage, bringing in a porter who sweats for gentlemen and whose back bears men.

Although the intrigue continues until Act IV, scene i, when Quomodo takes possession of Easy's lands, it is a fait accompli when Easy signs the bond as Blastfield's guarantor. Quomodo sends for Dustbox, the scrivener, to draw up the note, and Easy agrees with Blastfield, "You shall have your will of me for once" (II. iii. 336). Then, exhibiting a vanity in his penmanship, Easy asks of Dustbox:

How like you my Roman hand, i'faith?

Dustbox: Exceeding well, sir, but that you rest too much upon your R's, and make your E's too little.

Easy: I'll mend that presently.

Dustbox: Nay, 'tis done now, past mending. [Shortyard signs.] You both deliver this to Master Quomodo as your deed?

Shortyard: We do, sir.

Quomodo: I thank you, gentlemen. [Exit Dustbox.] [II. iii. 346-353]

The completion of this transaction completes the fraud as sodomitical act and the sodomy as fraudulent act. While resting on his R's/arse, Easy has signed away the ownership of his land (albeit as yet unknown to him). Also by signing and resting on his R's/arse, he has made his E's/ease/Easy too little-giving his land away, becoming impotent, becoming unshapen. 
Current vulgarity can convey the same multiple meanings: by signing the bond, Easy has been screwed.

Two other puns are also at work in this passage. "Deed" (351) refers both to the signed document and to the deed/act of sodomy; these having been delivered to Quomodo, Easy is now under his domination. "Done" recalls the various uses of "undone" noted earlier; in this instance, Easy's undoing is "done now, past mending [undoing]" (350).

If Michaelmas Term is read without references to the sodomy and the religious language, then Easy's land alone is what is at stake for its resolution; the restoration of the land to his ownership, therefore, corrects the disordering wrought by Quomodo and his accomplices. But even in Leinwand's reading, where the focus of his study is the sodomy, the issue in the denouement is not what is to be done, if anything, about Easy's sodomy, but the restoration of his social status:

Even though we know the case to be more complex, sodomy and gentility seem first and equally to mark out Easy, then to be ideologized. It may be that within the context of the song school theater, sodomy and gentility are also recuperated. Easy's triumph over Quomodo preserves the young man's estate in the face of a duplicitous citizen's land grab. Easy's final exit, without Thomasine (or the never-intended Susan), suggests his availability within an at least gentle homoerotic circuit. But even among the gentlemen at St. Paul's, Middleton insists that money, not merely port and carriage, qualifies gentle (erotic) relations. Money, in the form of Easy's rents, makes for the very possibility of a sodomite who is also a gentleman. ["Redeeming" 62]

This conclusion is untenable, even within the confines of Leinwand's own argument, because he too notes the equivalent sodomitical and economic meanings inherent in "undo" and, for his own argument, in the 
asserted pun on "beggar" as "bugger" (58). Would, therefore, one form of "undoing," the economic, be redressed in the conclusion without the other form, the erotic, being redressed as well? But he mentions only that Easy regains his estate.

Leinwand could have easily answered that the sodomy is redressed when Easy cuckolds Quomodo by marrying Thomasine after Quomodo fakes his own death. But he does not make even this claim, which would not necessarily have caused him to alter his argument for Easy's ongoing sodomitical character. He chooses instead to omit that marriage from discussion and noting only "Easy's final exit without Thomasine." Without reading the play, a reader of Leinwand's article would never know the marriage takes place. Accordingly, for his argument, economic undoing really is worse than erotic undoing, despite his claim that both meanings have equal force.

But how is the recovery from the economic undoing shown? Even this Leinwand only mentions-"Easy's triumph over Quomodo ..."-rather than demonstrates. His main argument ends with Shortyard at Act III, scene v, lines 59-60: "I'll venture my body no further for any gentleman's pleasure." He proposes that this line would register with a boy actor who, as actor and as ingle, might like to make such a choice. Interesting as such a consideration might be, it too involves an omission, the villainy of Shortyard's character. However, the largest omission in Leinwand's argument is Acts IV and V; Act IV receives only two minor citations in 
endnote 20. Thus, and only thus, buggery remains an option for Easy, with his lands restored by some means not examined.

Although the risk for Easy includes his land, which all critics acknowledge, and his sodomitical seduction, which Leinwand foregrounds, there is more at stake-his soul. This should be obvious from what has been discussed of his prodigality and lack of grace. But equally significant for understanding the meaning of sodomy from Middleton's Jacobean Christian perspective is the fact that two-thirds of Easy's opponents, Shortyard and Falselight, are spirits. Both are referred to as spirits even in the original stage directions and the introduction to their characters in Act I, scene i:

[Enter] Quomodo with his two spirits, Shortyard and Falselight. Quomodo: Oh my two spirits, Shortyard and Falselight, you that have so enrich'd me. I have industry for you both! [73-75]

Within the same scene, Quomodo calls Shortyard "my pregnant spirit" (90), "my sweet spirit" (128), and "my most cheerful spirit" (131). Similar references continue in Act IV; scene one opens with "Enter Quomodo, his disguised spirits, after whom Easy follows hard," and Quomodo concludes their cozening of Easy with congratulations, "Excellent, excellent, sweet spirits!" (IV. i. 59).

Because the spirits do not perform ostensibly supernatural acts and because they are only known as spirits to Quomodo, themselves, and possibly to the judge in Act $V$, critics have generally referred to them as "spirits" in quotation marks. Levin notes "something of the farcical tradition of the medieval 'Vice"' in "their frequent change of roles and their 
mischievous delight in them" (xvii). He adds in a footnote, "The fact that Shortyard and Falselight are called 'spirits,' and the opening lines of III. iii, led Alexander Dyce to claim they were 'more than mere mortal agents'; but later editors deny this since they have no supernatural powers" (xvii). Other spiritual agents in Middleton's works include the Succubus, Malkin the spirit-cat in The Witch, Hecate in Macbeth (according to much current criticism), and Lawrence Lucifer in The Black Book. In comparison to the others, Shortyard and Falselight are naturalistic characters; what they do, human characters could do.

However, such dismissals neglect seventeenth-century expectations of what makes a spirit a spirit. The theatre audience would have heard the constant reminders from Quomodo that Shortyard and Falselight were his spirits. If these can be discredited because of the speaker, the reader of the first quarto would also be faced with the stage directions cited above which label the characters as spirits. Shortyard himself answers the question of what characterizes a spirit when he and Falselight are disguised as sergeant and yeoman to arrest Easy (the scene begins as if in mid-speech):

So, no man is so impudent to deny that. Spirits can change their shapes, and soonest of all into sergeants, because they are cousingermans to spirits; for there's but two kind of arrests till doomsday: the devil for the soul, the sergeant for the body; but afterward the devil arrests body and soul, sergeant and all, if they be knaves still and deserve it. [III. iii. 1-7; emphasis added]

Shortyard assumes at least four shapes within the play: as Master Blastfield, as the sergeant, as the London citizen, and as whatever his undisguised form 
would be. Falselight, too, appears in five shapes: as the porter, as Master Idem, as the yeoman, as another London citizen, and in his undisguised form.

As noted in chapter two, shape-changing is characteristic of the supernatural attributes assigned to spirits in Middleton's time. In Paradise Lost, fallen spirits,

when they please

Can either Sex assume, or both; so soft

And uncompounded is thir Essence pure,

Not ti'd or manacl'd with joint or limb,

Nor founded on the brittle strength of bones,

Like cumbrous flesh; but in what shape they choose

Dilated or condens't, bright or obscure,

Can execute thir aery purposes,

And works of love or enmity fulfil. [I. 423-431]

This mutability makes available to the fallen angels a possibility for bodily sexual union. In contrast, the angel Raphael describes to Adam the greater opportunities for loving union available to the unfallen angels:

Whatever pure thou in the body enjoy'st

(And pure thou wert created) we enjoy

In eminence, and obstacle find none

Of membrane, joint, or limb, exclusive bars:

Easier than Air with Air, if Spirits embrace,

Total they mix, Union of Pure with Pure

Desiring; nor restrain'd conveyance need

As Flesh to mix with Flesh, or Soul with Soul.

[VIII. 622-629]

Gregory Bredbeck concludes that the union of unfallen angels is regarded as superior because "while the fallen spirits can range freely thoughout the system of sex and gender, unfallen spirits can range freely outside of it" (228). .24 
While the usual interpretation of the danger for Easy is to his estate, insofar as he is a prodigal, his soul is also in jeopardy from Shortyard's attempt on his body and soul: "the devil for the soul, the sergeant for the body; but afterward the devil arrests body and soul, sergeant and all, if they be knaves still and deserve it" (III. iii. 4-7). Thus Shortyard asserts his own selfhood as a spirit by linking his demonic intents to his multiple disguises; if he had his way, he would drag Easy to hell.

The earliest mention of spirits in this play immediately foregrounds the role of sex in their activities. This comes before we are introduced to the characters of the main plot. Rearage and Salewood are discussing the prospects Salewood's unnamed cousin would have for marriage:

[Salewood:] Faith, when all's done we must be fain to marry her into the North, I'm afraid.

Rearage: But will she pass so, think you?

Salewood: Puh, any thing that is warm enough is good enough for them; so it come in the likeness, though the devil be in't, they'll venture the firing.

Rearage: They're worthy spirits, i'faith. [I. i. 16-22; emphasis added] What Salewood and Rearage are suggesting is that if the Northerners are satisfied with succubi (the warm likeness of a woman with the devil in it, a "worthy spirit"), then the cousin, who is no longer a virgin, should still be able to find a husband. Shortyard resembles the succubi alluded to here in both his demonic and sexual "likeness." In this Shortyard also resembles Penitent's Succubus, "likeness" being their common mode of entrapment.

Most sexual relationships between spirits and people in Renaissance demonology are heterosexual-female succubi mate with men, male incubi 
mate with women. Yet, spirits are often connected to sodomy in Jacobean literature. In 1621, two of Middleton's collaborators, William Rowley and Thomas Dekker, worked with John Ford to produce The Witch of Edmonton. Dog is the main devil assisting Elizabeth Sawyer, the witch. In the subplot, Young Cuddy Banks wants to learn the secrets of lovemaking and meets Dog in the woods after a morris dance:

[Young Banks:] What might one call your name, dog?

Dog: My dame calls me Tom.

Young Banks: 'Tis well, and she may call me Ass, so there's an whole one betwixt us, Tom-Ass. She said I should follow you, indeed. Well, Tom, give me thy fist, we are friends. You shall be mine ingle. I love you, but I pray you let's have no more of these ducking devices.

Dog: Not, if you love me. Dogs love where they are beloved. Cherish me, and I'll do anything for thee. [III. i. 114-122]

After this, Banks repeatedly refers to Dog as his ingle.

Although sodomy does not figure prominently in its plot, the title itself of Jonson's The Devil is an Ass also suggests the connection of sodomy with spirits. While expressing his wish to meet a devil, Fitzdottrel offers himself and his wife to be used sexually:

Pray thee, come,

I long for thee! An I were with child by him, And my wife too, I could not more. Come yet, Good Beelzebub! [I. ii. 30-33]

Once Fitzdottrel meets Pug, the devil, their discourse strays into anal reference:

Fitzdottrel: What countryman?

Pug: Of Derbyshire, sir, about the Peak.

Fitzdottrel: That hole belong'd to your ancestors?

Pug: Yes, Devil's arse, sir. [I. ii. 89-92] 
When the Devil's arse is referred to as a location, we should recall the "Summoner's Prologue" in The Canterbury Tales, where the summoner claims a "nest of freres" inhabits "Sathanas' ers," a sodomitical insult to the summoner's opponent, the friar (Fragment III, lines 1665-1708).25

The most important texts linking spirits to sodomy for Middleton and his Jacobean audience, finally, are Biblical narratives. In the destruction of Sodom (Genesis 19: 1-29), angels visit Lot and his family to warn them out of the city. The men of Sodom surround Lot's house and demand he surrender his guests to them for their sexual activities. In this case, the desire is of humans for spiritual beings, although the angels appear as men.

More significant to this discussion is a narrative paralleling the events of Sodom in Judges 19. Here a Levite on his way to the house of the Lord with his concubine passes through Gibeah, a town in the tribal territory of the descendents of Benjamin. They meet up with an old man who insists they not spend the night on the street:

So he brought him into his house, and gave provender unto the asses: and they washed their feet, and did eat and drink. Now as they were making their hearts merry, behold, the men of the city, certain sons of Belial, beset the house round about, and beat at the door, and spake to the master of the house, the old man, saying, Bring forth the man that came into thine house, that we may know him.

[19: 21-22]

As in Genesis 19, the men are offered the women in the house, the Levite's concubine and the old man's daughter. The men take the concubine, rape and murder her. All of this leads to a civil war in which the Benjamites are almost destroyed (Judges 19-21). 
Old Testament uses of "Belial" do not require the word to refer specifically to a spirit; instead it is a personification of worthlessness and destruction (OED). Those committing certain acts of debauchery are often referred to as sons or daughters of Belial. The acts of debauchery include idolatry (Deuteronomy 13: 13), drunkenness (I Samuel 1: 14-16), selfishness and wrath (I Samuel 25: 1-17), and, as above, attempted sodomy and rape. In the New Testament, however, Belial becomes a proper name of the spirit opposed to Christ, another name for Satan:

Be ye not unequally yoked together with unbelievers: for what fellowship hath righteousness with unrighteousness? and what communion hath light with darkness? And what concord hath Christ with Belial? or what part hath he that believeth with an infidel? [II Corinthians 6: 14-15]

While the Biblical uses of "Belial" do not always require an interpretation of the involvement of a supernatural demonic being, they could be read with that interpretation in the Renaissance. Therefore, with the discourses linking sodomy to demons appearing in the Bible (or its interpretations), in the works of Middleton's contemporaries (including Jonson and Rowley), and in Middleton's ownMicrocynicon, there is no compelling reason for omitting demonic attributes and sodomy from Shortyard's characterization. And if these are included with his characterization, then credence should be given to Shortyard's stated intention of arresting Easy's body and soul.

The progress of Easy's downfall continues on through Shortyard's disguises as a sergeant and a citizen, until Quomodo finally takes possession of Easy's land, and declares, "Y'are a free man, sir; you may deal in what you 
please, and go whither you will" (IV. i. 49-50). Easy's financial undoing is completed then, but there is more undoing to be done in Michaelmas Term. The text does not validate Dustbox's judgment, cited earlier, "'Tis done now, past mending" (II. iii. 350).

The reason is that judgment is stated to be reciprocal, the reaping of what has been sown. In Act $V$, scene $i$, Shortyard observes,

This is the fruit of craft.

Like him that shoots up high, looks for the shaft, And finds it in his forehead, so does hit

The arrow of our fate; wit destroys wit. [41-44]

Even before Easy's gulling is complete, Thomasine, Quomodo's wife, states the same principle, but in language which refers to both Easy's undoing and Quomodo's eventual undoing: "he that sows in craft does rape in jealousy" (III. iv. 246-247). The early printers of the play were apparently unsure of how to read this line; "rape" appears in the corrected first quarto, but "reape" is used in the uncorrected first and the second quartos. Clearly, both meanings are intended. By sowing in craft, Quomodo and his spirit assistants do take sexual advantage of Easy, but Quomodo will also reap what he has sown in craft, reciprocally. 26

Quomodo himself is savvy enough to recognize that his cozenage could be undone, but he expects that it would happen after he dies, with his son behaving much as Easy has done with his inheritance:

And because I see before mine eyes that most of our heirs prove notorious rioters after our deaths, and that cozenage in the father wheels about to folly in the son, our posterity commonly foil'd at the 
same weapon at which we play'd rarely; and being the world's beaten word, what's got over the devil's back (that's by knavery) must be spent under his belly (that's by lechery); being awake in these knowings, why should not I oppose 'em now, and break destiny of her custom, preventing that by policy, which without it must needs be destiny? [IV. i. 81-91]

Quomodo joins two principles of justice which for Middleton would have their roots in the Bible: the judgment of a father visited upon the following generations and the reciprocal judgment of reaping what one has sown. Relevant Biblical passages include "I the Lord thy God am a jealous God, visiting the iniquity of the fathers upon the children unto the third and fourth generation of them that hate me" (Exodus 20: 5, from the Ten Commandments), and "Be not deceived; God is not mocked: for whatsoever a man soweth, that shall he also reap" (Galatians 6: 7). Quomodo treats these principles of divine justice as if they were a kind of natural law, "the world's beaten word" and "destiny," but which he still hopes he may oppose by "policy" (crafty calculation according to Levin's annotation).

Quomodo decides to oppose this destiny by faking his own death and disguising himself as a beadle to observe how his family responds to his passing. Shortyard immediately proceeds to gulling Sim, Quomodo's son, of the inheritance, and Thomasine sends for Easy with the intention of remarrying. As the funeral procession heads to the church, Quomodo in his disguise hears Sim insult him and decides to disinherit him.

Meanwhile, on the same day as the "funeral," Thomasine and Easy marry, and Easy forces Shortyard to surrender all the property back to him. Still disguised, Quomodo returns to receive payment for his services to the 
funeral. Thomasine requests that he sign a receipt stating that he has received all that is due him from the house of Richard Easy. Quomodo signs it without reading it, but once he discovers what he has done, he takes Easy and Thomasine to court. The judge rules that Easy keeps the property, but that his marriage to Thomasine is annulled. Quomodo faces no further penalty, but Shortyard and Falselight are banished.

Quomodo correctly assumes his son's inability to manage his inheritance. However, he believes two mistakes about the judgement coming to him-first, that he can get around it, and second, that it would manifest itself primarily in the behavior of Sim. Thus, while knowing the possibility that he faces a reversal of his deeds, Quomodo ironically causes that reversal by faking his death and freeing Thomasine to take action. His undoing of Easy is undone by his own undoing, sexually and financially, in a series of actions with parallel patterns to Easy's downfall.

Quomodo's sexual undoing is not as direct as Easy's; instead of being seduced, he is cuckolded. But as we have seen, he set the terms for judging the value of his wife: "They're busy 'bout our wives, we "bout their lands" (I. i. 107) and "I am as jealous of this land as of my wife" (IV. i. 110-111). Like Easy, he loses sexually even before he loses financially, and, similarly, the first loss causes the second. And as Easy has done, Quomodo deceives himself about the faithfulness of his partner. He praises Thomasine:

What a wife hast thou, Ephestian Quomodo! So loving, so mindful of her duty, not only seen to weep, but known to swoon! I knew a widow about Saint Antlings so forgetful of her first husband that she married 
again within the twelve-month; nay, some, by'rlady, within the month; there were sights to be seen! Had they my wife's true sorrows, seven months nor seven years would draw 'em to the stake.

Of course, unknown to Quomodo, Thomasine has outdone all of the wives he mentions, having remarried the same day as his funeral. 27

Although this undoing is ostensibly the result of a heterosexual cuckolding, Middleton verbally links it to reminders of Quomodo's sodomy. While disguised, he joins his son to hear how his "death" affects him:

[Quomodo:] Oh, my young worshipful master, you have parted from a dear father, a wise and provident father.

Sim: Art thou grown an ass now?

Quomodo: Such an honest father-

Sim: Prithee, beadle, leave thy lying; I am scarce able to endure thee, i'faith; what honesty didst thou e'er know by my father? [IV. iv. 27-33]

Whereas earlier Easy rested too much on his R's/arse, Quomodo is "grown an ass now," about to be undone himself. 28

Furthermore, like Easy making his E's/ease/Easy too little and becoming unshapen, Quomodo is also forgetting himself. His disguise as a beadle becomes linked with the demonic shape-shifting noted earlier. In the court scene, Easy is questioned about Quomodo's identity: "We are not certain yet it is himself,/ But some false spirit that assumes his shape/ And seeks still to deceive me" (V. iii. 12-14). When Quomodo himself is questioned, his identity is linked to his behavior; when he denies his cozenages, the judge rules that Quomodo is therefore an impostor:

Judge: Now, what are you?

Quomodo: I am Quomodo, my lord, and this my wife; Those my two men, that are bound wrongfully. 
Judge: How are we sure y'are he?

Quomodo: Oh, you cannot miss, my lord.

Judge: I'll try you;

Are you the man that liv'd the famous coz'ner?

Quomodo: Oh, no, my lord.

Judge: Did you deceive this gentleman of his right, And laid nets o'er his land?

Quomodo: Not I, my lord.

Judge: Then y'are not Quomodo, but a counterfeit.-

[To Officers.] Lay hands on him, and bear him to the whip.

Quomodo: Stay, stay a little,

I pray; now I remember me, my lord,

I cozen'd him indeed, 'tis wondrous true. [V. iii. 16-29]

Earlier, Easy's claim to have no being without Blastfield's company played into Quomodo's plot against him; here Quomodo's self denial backfires-he is either a cozener or an impostor, but in either case, he is guilty. This line of questioning ends with his admission, "I am found what I am" (V. iii. 33).

The final parallel between Easy's undoing and Quomodo's is Quomodo's signing of the receipt for his service to the funeral. After Quomodo signs it (still disguised as a beadle), Easy walks in and discovers his signature. Quomodo orders Easy out of his house, apparently forgetting that Easy and Thomasine still expect him to be dead:

Thomasine: What, is the beadle drunk or mad?

Where are my men to thrust him out o'doors?

Quomodo: Not so, good Thomasine, not so.

Thomasine: This fellow must be whip'd.

Quomodo: Thank you, good wife.

Easy: I can no longer bear him.

Thomasine: Nay, sweet husband.

Quomodo: Husband? I'm undone, beggar'd, cozen'd, confounded forever! Married already? -Will it please you know me now, Mistress Harlot and Master Horner? Who am I now? [Discovers himself.]

Thomasine: Oh, he's as like my tother husband as can be.

[V. i. 112-120] 
Significantly, Middleton has Quomodo declaring himself undone just after Easy declares he "can no longer bear him" (116). The immediate reference is to the supposed beadle's behavior, but "to bear" someone can also refer to having the subordinate position in sodomy, which informs the earlier reading of porters' backs bearing men (II. iii. 319-322).

The language of Quomodo's complaint of having been "undone, beggar'd, cozen'd, confounded forever" ostensibly refers to his financial reversal, caused by signing the receipt. But this complaint is bracketed within his discovery of having been made a cuckold_-"Husband? ... Married already?"-and "beggar'd" may pun on "buggered," as Leinwand concludes from an earlier usage ("Redeeming Beggary" 54). Just as Easy's financial and sodomitical undoings were essentially complete when he signed Quomodo's promissory note, so also are Quomodo's undoings by his signing the receipt. In Act $V$, the judge restates the principle of reciprocal justice, "Deceit is her own foe,/ Craftily gets, and childishly lets go" (V. iii. 73-74). After ruling that Easy keeps the property but that Quomodo remains married to Thomasine, the judge concludes his judgment, "Thou art thine own affliction, Quomodo" (V. iii. 164), adding no further penalty.

Were Easy merely a victim of Quomodo, the reversal of Quomodo's fortunes would suffice to rectify his loss. But as argued earlier, Easy's prodigality and active participation in sodomy makes him culpable as well for his own fall. Thus, in accord with his Christian perspectives, Middleton includes a repentance in Easy's restoration. Usually, as in A Mad World 
and $A$ Chaste Maid, the penitent makes his or her change upon confronting a representation of his or her wrongdoing, such as when Penitent reads Parson's Resolutions, or when Sir Walter Whorehound is shown his bastard children. In Easy's case, however, his restoration begins externally with the actions of Thomasine.

The humor in Thomasine's character is her eager desire (including sexual desire) to drop Quomodo for another man; in refusing Lethe's insulting advances, she says, "Tis for his betters to have opportunity of me" (II. iii. 7-8). Her desire becomes focused on Easy when they first meet:

Easy: Is that your wife, Master Quomodo?

Quomodo: That's she, little Thomasine!

Easy: Under your leave, sir, I'll show myself a gentleman.

Quomodo: Do, and welcome, Master Easy.

Easy: I have commission for what I do, lady, from your husband. [Kisses her.]

Thomasine: You may have stronger commission for the next, an't please you, that's from myself.

Easy: You teach me the best law, lady.

Thomasine [aside]: Beshrew my blood, a proper springall and a sweet gentleman. [II. iii. 395-404]

Because Thomasine makes no apparent attempt to hide from Quomodo her offer of stronger commission to Easy, her last comment does not necessarily have to be an aside. However, Thomasine is also a stickler for the law, of which Easy says she is his teacher. Their fastidiousness about commission here is merely one case in point of her focus on law.

Quomodo's cozenage always has the veneer of legality, involving a promissory note, cosigners, a scrivener, and Shortyard's disguises as the sergeant and the citizen offering bail. Thomasine, who witnesses most of 
Easy's cozening, sees right through this image, but her perspective seems to be that she is legally bound not to reveal the scope of Quomodo's plans to Easy. ${ }^{29}$ When Easy and Shortyard first come to his shop, Quomodo refuses to let Thomasine stay; she responds, "Well, since I am so expressly forbidden, I'll watch above i'th' gallery, but Ill see your knavery" (II. iii. 78-79). Twice during Easy's gulling (II. iii. 202-207 and 341-343), Thomasine compares what she sees to watching an execution which she is powerless to prevent; in the first instance, she also questions Quomodo's sexuality:

Why stand I here (as late our graceless dames That found no eyes) to see that gentleman [Easy]

Alive, in state and credit, executed, Help to rip up himself, does all he can?

Why am I wife to him that is no man?

I suffer in that gentleman's confusion. [II. iii. 202-207]

In a later scene, again watching Easy's gulling, Thomasine remarks to herself her love for Easy:

My love is such unto thee, that I die As often as thou drink'st up injury, Yet have no means to warn thee from't; for "he That sows in craft does rape in jealousy." [III. iv. 244-247]

The line in quotation marks here is also marked in the first two quartos of the play, although no editor of the play has yet noted its source. Earlier I referred the line to the Quomodo's "rape" of Easy, but it can also refer to Quomodo's jealous dominance over Thomasine. It would be possible to read Thomasine's inability to help Easy (or to mate with him) as the result of Quomodo's physical domination. However, because she is Easy's teacher 
of "the best law," because she considers herself in a position analogous to a witness at an execution, and because her quote seems to have for her a kind of authority, we should consider that Thomasine might also see legal barriers to acting on Easy's behalf.

In Paul's Epistle to the Romans, living under the law is compared with living in a first marriage:

Know ye not, brethren, (for I speak to them that know the law) how that the law hath dominion over a man as long as he liveth? For the woman which hath an husband is bound by the law to her husband so long as he liveth; but if the husband be dead, she is loosed from the law of her husband. So then if, while her husband liveth, she be married to another man, she shall be called an adulteress: but if her husband be dead, she is free from that law; so that she is no adulteress, though she be married to another man. Wherefore, my brethren, ye also are become dead to the law by the body of Christ; that ye should be married to another, even to him who is raised from the dead, that we should bring forth fruit unto God. [Romans 7: 1-4]

Thomasine, Easy's teacher of "the best law," functions much as the wife in this passage. When Quomodo fakes his death, she presumes herself free of her husband and free to remarry. The benefit of her new-found freedom, however, accrues to Easy.

In Calvinist theology, the natural inclination of people is not towards their salvation, but away from it. Any benefit, or grace, that a person receives, therefore, comes independently of his or her merit or desire; the desire for salvation in Calvinist theology is itself a result of the work of divine grace. Easy's restoration, then, begins not from himself, but from Thomasine's desire. Immediately after learning of Quomodo's death, she sends her maid to inquire for Easy, who resides, maybe significantly, "i'th' 
Blackfriars" (IV. iii. 29-30). We are then told that she "sent him a hundred pound tother day to comfort his heart," and she now "has that virtue to recover him again forever" (IV. iii. 31-34).

When Easy arrives, Thomasine immediately proposes their marriage, a marriage much like the second one which in Romans indicates a salvation:

Thomasine: My most sweet love!

Easy: My life is not so dear.

Thomasine: I have always pitied you.

Easy: Y'ave shown it here, And given the desperate hope!

Thomasine: Delay not now, Y'ave understood my love; I have a priest ready;

This is the fittest season, no eye offends us,

Let this kiss

Restore thee to more wealth, me to more bliss.

Easy: The angels have provided for me. [IV. iv. 72-79]

Easy speaks like a sinner finding salvation-"My life is not so dear. ... Y'ave ... given the desperate hope! ... The angels have provided for me." Although Thomasine's desire for Easy has been notably sexual, she circumscribes her desire within the bounds of law-"T have a priest ready."

This passage also introduces a significant contrast of kisses. Whereas Shortyard was to "creep into bed to [Easy],/ Kiss him and undo him" (I. i. 127-128), Thomasine's kiss within the best law is to "Restore [Easy] to more wealth, me to more bliss." When Thomasine sends for Easy, her purposes are "both to do that gentleman good and do myself a pleasure" (IV. iii. 40-41); contrast Shortyard who "ne'er didst mistress harm, but master good" (I. i. 87). The kiss of sexual and spiritual undoing has been undone by Thomasine's sexual and spiritual kiss of doing good. 
Having received the provision of the angels, Easy completes his restoration with a repentance: "My joys exceed;/ Man is ne'er healthful till his follies bleed" (V. i. 14-15). Once Easy has forced Shortyard to surrender the deeds to his property, he repents in language conflating his actions and his property, punning on "deeds":

Here's good deeds and bad deeds, the writings that keep my lands to me, and the bonds that gave it away from me. These, my good deeds, shall to more safety turn, And these, my bad, have their deserts and burn.

The bad deeds are "bonds," recalling the bondage of sin from which one would desire to be free. Easy's repentance may have I Corinthians 3: 13-15 as its background, especially since "deeds" and "work" are synonymous:

Every man's work shall be made manifest: for the day shall declare it, because it shall be revealed by fire; and the fire shall try every man's work of what sort it is. If any man's work abide which he have built thereupon, he shall receive a reward. If any man's work shall be burned, he shall suffer loss: but he himself shall be saved; yet so as by fire.

Easy's repentance should not be taken to suggest that his good deeds bring about his salvation; his salvation seems to have been accomplished when the angels provided for him and his joys exceeded. This repentance also problematizes Leinwand's conclusion that Easy is free to re-enter a gentle homoerotic circuit. To conclude that requires omitting sodomy from Easy's deeds, negating the pun on deeds as actions. Easy exits the play without Thomasine, but, having repented, not to find other male lovers.

This reading of Michaelmas Term, based on examining the play within the religious context of Middleton's other works, the religious contexts of 
his time, and the current discourses on sodomy, reaches an opposite conclusion of Easy's status at the end of the play from Leinwand's reading. In the context of our current politics, it may seem that I am reading Michaelmas Term as a more homophobic play in contrast to Leinwand's more gay-friendly reading. This divergence of critical opinions appends itself to other Renaissance texts and authors which treat the subject of sodomy or homosexuality, so that we get such famous claims as Shakespeare was a heterosexual, a bisexual, and a homosexual. This comes from making an ontological claim about a person from another era when the ontological premises of that era differ from our own.

A contrast may be useful to situate my reading in critical context. Current critical opinion generally agrees on Christopher Marlowe's homosexuality, and his Edward II is read as offering possible conditions for homosexual subjectivity. Yet, Edward II is nonetheless an anxious play, as if there were not and could not be any conceivable accommodation-social, religious, or political-whereby Edward's and Gaveston's relationship could be legitimized. Readings trying to make that accommodation, or examining its absence, depend on valorizing the lovers' rebellion against the religiouspolitical structures they face. But the lovers lose, with Edward's body dumped in the castle's sewer.

Edward II is a play where all the choices are extreme. Is the king to be favored? Then so is his weak policy, immoderate desire, irreligion, and petulance. Are the nobles and bishops to be followed? To the overthrow of 
a legitimate king, the approval of treason, and the overreaching of Roman religious authorities. Edward II is a play of disruptive questioning, but not altogether of disruptive answering; Edward III ends up on the throne, punishing the traitors.

Although Edward II is more commonly examined by gay critics, Michaelmas Term is as thorough in considering the subject of sodomy. And while spirits roam through London seeking whom they may devour, Michaelmas Term seems less anxious about the political and social implications of sodomy than Edward II. One of the similarities between Edward II and Michaelmas Term is that both texts posit homoerotic desire independent of transvestism. But Michaelmas Term also shows an accommodation missing in Edward II. Sodomy can be included in Middleton's picture of London because it was already accommodated-in the theatre, but also as a practice of the friendships of some gallants. When in Act III, scene v, Easy searches for "Master Blastfield," we find that Salewood and Rearage also want to find him, and they are both aware that Easy is sleeping with him:

Salewood: Master Easy, how fare you, sir?

Easy: Very well in health. Did you see Master Blastfield this morning? Salewood: I was about to move it to you.

Rearage: We were all three in a mind, then.

Salewood: I ha' not set eye on him these two days.

Rearage: I wonder he keeps so long from us, i'faith.

Easy: I begin to be sick.

Salewood: Why, what's the matter?

Easy: Nothing, in troth, but a great desire I had to have seen him. Rearage: I wonder you should miss on't lately; you're his bedfellow. Easy: I lay alone tonight, i'faith. [III. v. 35-46] 
Although this conversation could exist in the discourses of friendship independent of sodomy, for the audience too much has already been said of sodomy to omit it here. Yet the prospect of Easy's sodomy produces no sense of anxiety for Salewood or Rearage. Although Leinwand mischaracterizes Middleton's portrayal of sodomy, he is correct in noting that "The play indicates that in some instances, homosocial relations in Jacobean London may have been founded upon, at the very least may not have been antipathetic to, homoeroticism" (54).

But Michaelmas Term goes even further than this picture of accommodation. Although there has never been any serious challenge to Middleton's authorship of the play, its first two editions, 1606 and 1630, were printed without authorial attribution; the first attribution to Middleton appears in Edward Archer's play list of 1656. If the banning of Microcynicon and other satires was because of "of a too lively interest in the very vices [the authors] claimed to be censuring" (Bray 33), and if one of Middleton's satiric strategies in Microcynicon was to use the narrative voice of a sodomite, then by naming a character with a feminization of his own name, "Thomas-ine," Middleton could have risked again being closely identified with what he censures. Thus we have a possible reason for the anonymous printing of the play. This name construction, moreover, could have been formed by combining "Thomas" with "epicene."

If my theory for how Thomasine was named is correct, we may easily suppose that Middleton himself would have been accounted a sodomite by 
the antitheatrical writers. In The Anatomy of Abuses, Philip Stubbes argues that transvestism actually transforms a person's sex:

It is written in the 22 of Deuteronomie, that what man so ever weareth womans apparel is accursed, and what woman weareth mans apparel is accursed also. Now, whether they be within the bands and lymits of that curse, let them see to it them selves. Our Apparell was given us as a signe distinctive to discern betwixt sex and sex, \& therefore one to weare the Apparel of another sex, is to participate with the same, and to adulterate the veritie of his owne kind. Wherefore these women may not improperly be called Hermaphroditi, that is, Monsters of bothe kindes, half women, half men. [F5 verso]

Of course, the charge that theatrical transvestism leads to immorality was already being made for twenty years by the time Middleton wrote this play. But in a play where all the homosexual desire appears as the straightforward desire of one male for another, it is the transvestite boy actor with the feminized, or epicenic, version of the author's name who saves the sodomite. And the motivation for that salvation is shown as love for the sodomite, Thomasine's love for Easy.

Is this association of Thomasine with the author appropriate? Two features of her role suggest the answer is yes. First, like Shakespeare when he refers to himself through characters named Will or William, Middleton gives his "Thomas" characters lines which exhibit a knowledge he shares with the audience, but beyond the knowledge the characters can have of their own circumstances. The "Thomas" characters speak the truth unwittingly, as if from the position of their author. When Mother Gruel claims to be Lethe's poor drudge, Thomasine answers, "Faith, and thou wert his mother, he would make thee his drudge, I warrant him" (II. iii. 
25-27). Neither Thomasine nor Mother Gruel is aware that Lethe is indeed Gruel's son. Likewise in The Changeling, Tomazo, another Thomas, unwittingly identifies De Flores as the murderer of his brother Alonzo:

I must think all men villains, and the next

I meet (whoe'er he be) the murderer

Of my most worthy brother.-Ha! What's he?

[Enter De Flores, passes over the stage.] [V. ii. 6-8]

The second reason for associating Thomasine with Middleton is the play's frequent recourse to theatrical language when she appears. When Quomodo finds Thomasine conversing with Mother Gruel, he grouses, "How now, what prating have we here? Whispers? Dumb shows?" (II. iii. 31-32). She complains that Lethe treats his guests "behind the cloth like a company of puppets" (II. iii. 60-61). When Quomodo orders her to leave the shop, she decides, "I'll watch above i'th' gallery, but I'll see your knavery" (II. iii. 78-79). When she hears of Quomodo's death, her response is a selfconscious act: "I do account myself the happiest widow that ever counterfeited weeping" (IV. iii. 39-40). And, as noted earlier, she likens watching Easy's gulling to watching an execution. These uses of theatrical language in association with Thomasine point to the author Thomas. Of course, Thomasine is a persona, not a full-fledged surrogate for Middleton.

If theatre is what catches Easy in the actions of Quomodo and Shortyard, theatre is also what liberates Easy and catches Quomodo in the reenactment of the main elements of Easy's gulling. Theatre is thus not essentially moral or immoral; its rightness depends on its use-for 
Middleton, in support of Christian orthodoxy. And theatre will inevitably be used; repentance itself is a kind of performance. In some ways, the Biblical text even requires men to become like women. In the Epistle to the Romans, the male audience, "my brethren," is to be like the wife whose first husband has died by becoming "married to another, even to him who is raised from the dead"; men, in other words, are spiritually incorporated into the bride of Christ for the purpose of bringing "forth fruit unto God" (Romans 7: 4). The right use of theatre, here, emphasizes the particular transvestite practice which so bothered opponents of the theatre. To save the sodomite by the actions of a transvestite motivated by love makes nonsense of the antitheatrical arguments.

If my reading of Michaelmas Term might seem to make it a more homophobic play than Leinwand's reading, how would the play have looked to its first audiences, especially coming from a writer willing to risk identification with the monsters? We do not have contemporary records of its reception, but we can say that rather than picturing the sodomite as a monster whose very existence forbodes a national catastrophe, the play pictures a sodomite as a naive person who should be loved, corrected, and assimilated into society. Easy ends up far happier than Edward II ever could have according to the conditions offered in each play. Easy's end could have appeared a radical acceptance to the Renaissance audience-there is a social place for the (penitent) sodomite. 
IV. Redeeming the Sodomite Stage in The Roaring Girl

Although the creation of Thomasine inverts the arguments against theatrical transvestism, the explicit purpose of Michaelmas Term is not to oppose antitheatricalism but to warn naive gallants of urban dangers. In the Induction, when the character Michaelmas Term meets with the three other terms (Hilary, Easter, and Trinity, all named for legal seasons), the Third Term notes that

Many new fools come up and fee thee.

Second Term: Let 'em pay dear enough that see thee.

First Term: And like asses use such men;

When their load's off, turn 'em to graze again. [Induction 37-40]

As so often occurs in Middleton's writing, the moral points are made ironically by the immoral characters. When the Second Term proposes to "Let 'em [the many new fools] pay dear enough that see thee [both the character and the play of Michaelmas Term]," the audience of gallants have also been alerted against being used "like asses." At the end of the Induction, Michaelmas Term states the play will not be about great quarrels in law; rather,

this only presents those familiar accidents which happen'd in town in the circumference of those six weeks whereof Michaelmas Term is lord. Sat sapienti; I hope there's no fools i'th' house. [Induction 71-74]

Levin notes "Sat sapienti" is a shortened Latin form of the proverb, "Dictum sapienti sat est" ("A word to the wise is sufficient"), which appears in Plautus' Persa and Terence's Phormio. The "familiar accidents," therefore, are what the gallants are to be alert enough to prevent happening to 
themselves. At the play's end, Quomodo reiterates its moral import: "for craft, once known/ Does teach fools wit, leaves the deceiver none" (V. ii. 90-91). The didactic concern of Michaelmas Term is directed to the audience of gallants, potentially sodomites and fools, who are offered Easy as an example both of a fallen gallant and of one who is saved.

The stated purpose of the text of The Roaring Girl is the provision of erotically-charged mirth. Middleton's dedicatory epistle begins, "To the Comic Play-readers, Venery and Laughter" ("Epistle" 1).30 The editor Paul Mulholland notes that The Roaring Girl could be either an offering of venery and laughter to the play-readers, or an offering to their venery and laughter. This ambiguity, as Mulholland also notes, is probably created deliberately, and it leads to two conclusions-that an erotic text is an appropriate offering to the reader, and that such an offering would and should appeal to an innate desire for erotic fulfillment (the play-reader's venery). To drive home the point, Middleton soon claims,

Now in the time of spruceness, our plays follow the niceness of our garments: single plots, quaint conceits, lecherous jests, dressed up in hanging sleeves; and those are fit for the times and the termers. Such a kind of light-colour summer stuff, mingled with diverse colours, you shall find this published comedy-good to keep you in an afternoon from dice, at home in your chambers; and for venery, you shall find enough for sixpence, but well couched an you mark it. ["Epistle" 6-14]

From unexamined popular assumptions about Jacobean or Calvinist Christians, an intentionally erotic text would appear at odds with the moral standards, or the renunciation of the flesh, we could expect. Such 
assumptions can easily be challenged by pointing to Spenser's Amoretti and the erotics of Donne's religious poetry. But it would be equally misleading to suggest that an erotic offering would instead be unproblematic, especially from dramatists. Rather, the erotic power of the theatre was precisely a main focus of antitheatrical controversy, and to offer venery and laughter is a contestant strategy against antitheatricalism. By offering "quaint conceits [with the common pun on "quaint"], lecherous jests," enough venery for sixpence, good enough to replace dicing for an afternoon, to read in one's chambers, Middleton is, of course, advertising the commercial appeal of the play, but in language intended to recall and provoke the main arguments against the theatre.

Besides the offered bawdiness, Middleton also uses the extended metaphor of clothing fashion to claim the play is given in the latest popular style: "our plays follow the niceness of our garments" ("Epistle" 7-8). This recalls a main focus in antitheatrical argument. Although Philip Stubbes is most commonly known for his comments directed against the theatre, The Anatomy of Abuses actually has more to say against the "pride of apparell": "Pride is tripartite, namely, the pryde of the hart, the pride of the mouth, \& the pryde of apparell, which (unles I bee deceived) offendeth God more than the other two" (B6r). The reason is that "the pride of apparel, remaining in sight, as an exemplarie of evill, induceth the whole man to wickednes and sinne" (B6r). After this introduction, from the page headings we find Stubbes arguing against "newfanglednesse," "great ruffes," "monsterous 
dubblets," "great excesse in hose," "great excesse in shooes," "coloryng of faces," "wearing of eare-rings," and much more. William Perkins, another opponent of the theatre, likewise complains,

Here comes to be justly reprooved, the straunge practise and behaviour of some in these daies, who beeing not contented with that forme and fashion, which God hath sorted unto them, doe devise artificiall formes and favours, to set upon their bodies and faces, by painting and colouring; thereby making themselves seeme that which indeede they are not. [cited by Barish 93]

As Jonas Barish summarizes them, similar arguments can be found in antitheatrical texts by Gosson, Rainolds, and Prynne (chapter 4).

Middleton does not directly mention the antitheatrical arguments, but his mention of fashion and lecherous jests in promoting a theatrical text could hardly have been accidental in the context of those arguments. His suggestion that reading the play could replace dicing for an afternoon's recreation would have also recalled condemnations of dicing like those of Stubbes and John Northbrooke, an earlier theatre opponent. Indeed, Middleton and Dekker must have counted on their audience to connect the play to the arguments, and the connection itself could have drawn some of the audience. 31 Therefore, though the explicit purpose of The Roaring Girl is to provide venery and laughter, one implicit purpose is a defense of the theatre, particularly against the charges of sodomy, extending what has been started with the portrayal of Thomasine in Michaelmas Term.

I am not proposing, by the way, that The Roaring Girl is intended to convince the theatre opponents of the merits of theatre. Instead, the play 
seems designed to offend the opponents while simultaneously redeeming the stage from their allegations. With its transvestism, bawdiness, and sodomites, the redemption of theatre inThe Roaring Girl would not have persuaded the antitheatricalists.

The uniformity of antitheatrical arguments stems from their shared ancient and early Christian sources and from their borrowings (usually unacknowledged) from their immediate predecessors. Generally, the attacks on the theatre focus on the intentional theatrical destabilization of signs or signifiers from what they signify, bawdy language and performance, and transvestism. ${ }^{32}$ From these fundamental complaints, the arguments extend against theatrical violence, the provocation of lustful or violent behavior (including sodomy), and, depending on the religious perspective of the writer, the link of theatre with papistry. Detailed examinations of this antitheatricalism appears in Jonas Barish's The Anti-theatrical Prejudice and Laura Levine's Men in Women's Clothing. Thus, though I most frequently cite Stubbes, whose Anatomy had its last revised edition in 1595 (sixteen years before The Roaring Girl, though doubtless familiar to Middleton and Dekker), the main points of the antitheatrical arguments remained constant and contemporary from 1579, with Stephen Gosson's and John Northbrooke's publications, to the closing of the theatres in 1642.

If the 1606 play The Puritan, or the Widow of Watling-Street is Middleton's (see endnote 27), then his would be one of the few works to 
have received direct, specifically antitheatrical, condemnation. This should be distinguished from other kinds of condemnation aimed mainly to censor specific elements of plays, common enough for the well-known Jacobean dramatists. In a sermon dated February 14, 1607, William Crashaw denounces "the ungodly Playes and Enterludes so rife in this nation ... the divels owne recreation to mock at holy things" (170). Some of the features which particularly exercise Crashaw's ire are the "abomination for a man to put on womans apparell," "that hee that teacheth children to play is ... a spoiler and destroyer of children," and that "now they bring religion and holy things upon the stage" (170-171). Proving the last point, Crashaw cites the names of two characters from The Puritan:

Two hypocrites must be brought foorth; and how shall they be described but these names, Nicolas S[t]. Antlings, Simon S[t]. Maryoveries? Thus hypocrisie a child of hell must beare the names of two churches of God, and two wherein Gods name is called on publikely every day in the yeere, and in one of them his blessed word preached everie day (an example scarce matchable in the world): yet these two, wherein Gods name is thus glorified, and our Church and State honoured, shall bee by these miscreants thus dishonoured, and that not on the stage only but even in print. Oh what times are wee cast into, that such a wickednesse should passe unpunished!

[171]

The Puritan was in fact performed by the Children of Paul's, pertinent to Crashaw's complaint against the use of child actors. If the play is Middleton's, then because of this opposition and because the play is poorly written, there existed good reasons for him to have preferred its attribution to the unknown "W. S." If the play is not his, then even so, Crashaw's argument is contemporary to the prime of Middleton's city comedy work. ${ }^{33}$ 
While English Renaissance antitheatricalism has received widespread study, defenses of the theatre have received a more haphazard critical examination. At least part of the problem must be the question of what constitutes a defense of the theatre, and what is merely a theatrical use of material which is contested by theatrical opponents. Jonathan Crewe usefully reads Marlowe's Tamburlaine, Part 1 as participating in the same anxious cultural discourse about the nature and magnitude of theatrical images as William Rankins in his antitheatrical pamphlet $A$ Mirrour of Monsters; yet Crewe cautions against reading Tamburlaine as a response to Rankins (49). If critics were to begin to read plays indiscriminately as responses to the specific charges of theatre opponents, then every play could conceivably be a defense because every play participates in contested discourses. Such a strategy of reading would confirm the critical assumptions of totalitarian antitheatricalists like William Prynne, but would not tell us enough about the many discourses influencing and modified by the written and performed texts.

Formal defenses of theatre from the English Renaissance are quite rare. Barish cites two, playwright Thomas Heywood's An Apology for Actors (1612) and playwright and actor Nathan Field's "The Remonstrance of N. F. ... addressed to a Preacher in Southwark, who had been arraigning against the Players at the Globe Theatre" (1616). Of Heywood's Apology, Barish concludes, "It would be harder to imagine a more inept 'apology"' (119). The reason is that Heywood essentially concurs with the opponents about 
the nature of the stage- that it promotes violence, fraud, and rape; that it has origins in pagan ritual and idolatry-but Heywood cites these examples positively which the opponents would rail against (118-119). Heywood seems to mistake the antiquity of his examples for their argumentative power, despite the fact that the examples themselves, such as the rape of the Sabine women begun at a Roman theatre, are so grotesque as to favor the antitheatrical arguments. Another example of Heywood's is of Julius Caesar, playing Hercules, becoming carried away by his part and actually killing the actor who played Lichas (Barish 119). When Heywood claims, "I speake not in the defence of any lascivious shewes, scurrelous jests, or scandalous invectives" (F4r, cited by Barish 121), we could well wonder why not, after all he has already approved. Field's argument, though brief, is a more direct response to one opposition argument. To the claim that actors were not approved in the Bible, and therefore stand condemned, Field alleges that neither are "a hundred trades and misteries that at this day are lawful" (121-122).

Responses in the theatre are more common than formal arguments, and would include such scenes as Zeal-of-the-Land Busy arguing with and losing to Puppet Dionysius in Bartholomew Fair, and Paris' oration in defense of the reproving power of the stage in Massinger's The Roman Actor. Effective as these scenes may be on the stage, however, its defense is limited or undercut within the same play, even in the same scene. When Puppet Dionysius exposes himself to refute Busy's argument against 
theatrical transvestism, Jonson scores a comic point but evades the issue; he could not have the actor playing Ursula executing the same maneuver. While this scene is the most comprehensive staged defense of the stage, Jonson's own antitheatricalism merits the entire fifth chapter in The Antitheatrical Prejudice, suggesting an ambivalence which Bartholomew Fair does not wholly resolve. 34

In his introduction to The Roman Actor, Norman Rabkin notes that the play itself refutes Paris' defense of the stage-by leaving the characters morally unimproved by the plays within the play, by leaving adultresses and murderers unpunished, and by showing that a performance can include "real" violence (715). Indeed, much like Julius Caesar killing the actor mentioned in Heywood's Apology, Domitian Caesar stabs Paris during the play within the play in Act IV, scene ii. Read in the context of these other defenses, Heywood's Apology appears somewhat less inept for his time; if he shares the assumptions of his opponents, then so do other dramatists. ${ }^{35}$ On the other hand, we should also note that some antitheatricalists present their own attacks as types of drama: Prynne's Histriomastix is subtitled an "Actors Tragaedie" and is divided into acts and scenes; Gosson's second broadside against the stage is Plays Confuted in Five Actions.

Middleton's critique of doubleness of identity and unshapenness (discussed in relation to Easy and Shortyard) and his acknowledgement of sodomy among the players are at least potentially antitheatrical; they are all 
that a full-fledged theatre opponent would have needed to construct his argument. Furthermore, as noted in chapter two, theatre can be used to cozen an audience, as implicated as any human endeavour in human sinfulness. The answer for Middleton and Dekker, however, is not to condemn the theatre, which has been condemned already, but to redeem it.

They do this by recreating the argument, not as a dispute about theatre, but as a dispute first about eros. They use Moll Cutpurse, the roaring girl, as an emblem to advance the good functioning of both eros and theatre (Sebastian and Mary's marriage) and to tame the excessive reactions toeros and theatre (Sir Alexander's prohibitions and Laxton's licentiousness). The Roaring Girl conflates eros and theatre, so that the erotic issues within the play frequently parallel the issues about the theatre in social discourse. ${ }^{36}$ The roaring girl becomes Venus in Middleton's epistle, herself opposed by a statute and "some obscene fellow":

For Venus, being a woman, passes through the play in doublet and breeches: a brave disguise and a safe one, if the statute untie not her codpiece point! ... Worse things, I must needs confess, the world has taxed her for than has been written of her; but 'tis the excellency of a writer to leave things better than he finds 'em; though some obscene fellow, that cares not what he writes against others, yet keeps a mystical bawdy-house himself, and entertains drunkards to make use of their pockets and vent his private bottle-ale at midnight-though such a one would have ripped up the most nasty vice that ever hell belched forth and presented it to a modest assembly, yet we rather wish in such discoveries where reputation lies bleeding, a slackness of truth than fulness of slander. ["Epistle" 14-16, 19-30]

Middleton's and Dekker's portrait of Moll Cutpurse begins the redemptions in this play. Their character is based on the actual female 
transvestite, Moll Cutpurse, who was powerful in the London underworld for around fifty years-a thief and a leader of pickpockets, $a$ fencer of stolen goods, a brawler, a procuress of prostitutes, though from The Life and Death of Mrs. Mary Frith, a partly autobiographical record, it seems that she herself was not a prostitute. She was probably around twenty-five years old when The Roaring Girl was written. InThe Witch of Edmonton (1621), she is noted as a dog-lover and a fan of bull- and bear-baiting (V. i. 161-162).

In his prologue to The Roaring Girl, Dekker notes that each theatre attender may have preconceived notions about "what he would of a roaring girl have writ" (Prologue 5). They might believe she "roars at midnight in deep tavern bowls," "beats the watch," "swears, stabs, gives braves, / Yet sells her soul to the lust of fools and slaves" (17-20). While Dekker declares, "None of these roaring girls is ours: she flies/ With wings more lofty" (25-26), most of these behaviors are indeed part of the available biographical information and the character of Moll in the play. The only characteristic the play denies is that she sells her soul to others' lust.

What the authors offer as Moll Cutpurse is an improved version, redeeming her from an unchaste reputation-first, of what "the world has taxed her for"; second, of what "some obscene fellow that cares not what he writes against others" presents "to a modest assembly"; third, of what the audience, readers or theatre attenders "would of a roaring girl have writ"; and fourth, of the recreated reputations for looseness, opinions held by Sir Alexander, Laxton, the merchants' wives, and others, which the character 
Moll defends herself against: "'Cause you'll say/ I'm given to sport, I'm often merry, jest;/ Had mirth no kindred in the world but lust?" (III. i. 103-105). Middleton leaves himself an escape clause on the possible charge that he is too generous to Moll's reputation, claiming that he would rather "a slackness of truth than fulness of slander" (Epistle 29-30), i. e., that he would not indulge in unsubstantiated gossip, "such discoveries where reputation lies bleeding" (28-29). It is "the excellency of a writer to leave things better than he finds 'em" (21-22). (For the sake of easy reference, I will hereafter refer to the London personage as Mary Frith and the play character as Moll Cutpurse, but this distinction is one that the playwrights are obviously intent on diminishing.)

While the direct references of this passage from the Epistle is to Mary Frith, who is improved from her reputation, the first half of the Epistle refers to plays and how they are "dressed." The analogy of Moll Cutpurse as theatre, then, is established in this portion of the Epistle. While Mary Frith passes through London dressed as a man, here it is Venus, dressed as a man passing "through the play" (15), who may have her codpiece point untied by the statute. Mulholland annotates the statute according to what applies to Mary as a London citizen, but what statute applies to "brave disguises" within the theatre, passing through the play? No legal prohibitions, but the Deuteronomic code forbidding cross-dressing that theatre opponents want to apply to the theatre. The irony here, however, is that if the Deuteronomic code were applied to untie the codpiece point, the person thus revealed 
would be a man, who would have the appropriate anatomy for a codpiece, a "safe" disguise indeed for this "Venus."

The analogy of Moll as theatre carries further through the Epistle. The stage, too, has been taxed for worse things than disguisings. The "obscene fellow," then, becomes analogous to a theatre opponent. He is a writer who "would have ripped up the most nasty vice that ever hell belched forth and presented it to a modest assembly" (26-28). Although this could be a charge that an antitheatricalist would raise against dramatists-the overexposure of vice on the stage, here the overexposure occurs before a modest assembly (as in a church), the overexposure of Moll to the point of slander, and the overexposure of the vice of the stage.

The obscene fellow is also a hypocrite, a drunk who keeps a mystical bawdy-house (24). In $A$ Chaste Maid, the sign of the Puritans' hypocrisy is their drunkenness. Mulholland annotates "mystical" as "secret, concealed ... frequently linked to a sexually suggestive term," but it can also refer to secret religious rituals, such as those of the Family of Love. Finally, the word "obscene" itself is a theatrical reference-for something that cannot be presented in the scene, used for what must be referred to but not stated directly. Saving Moll from the slander of the obscene fellow becomes analogous to saving the theatre from the censures of its opponents. 37

The conflation of eros and theatre in the character of Moll Cutpurse extends, of course, into the play itself. Moll's defense against her reputation 
for looseness-"'Cause you'll say/ I'm given to sport, I'm often merry, jest;/ Had mirth no kindred in the world but lust?" (III. i. 103-105)-applies first in response to Laxton's attempts on her virtue. But her sports, merriness, jests, and mirth can refer as well to the pleasures of the stage, always associated with lust by its opponents.

In the Epilogue, Dekker promises the audience that if the play has not met their expectations,

The Roaring Girl herself, some few days hence, Shall on this stage give larger recompense;

Which mirth that you may share in, herself does woo you, And craves this sign: your hands to beckon her to you. [Epilogue 35-38] Typically, this epilogue craves the audience's applause by promising more of the Roaring Girl on the stage; in this case, however, the Roaring Girl can be both the play's character and the London personage. As a female crossdresser, Mary Frith was well aware of her theatrical persona. In a court record dated January 27, 1612, she confesses,

being at a playe about 3 quarters of a yeare since at the ffortune in mans apparell \& in her bootes \& with a sword by her syde, she told the company there present that she thought many of them were of opinion that she was a man, but if any of them would come to her lodging they should finde that she is a woman \& some other immodest \& lascivious speaches she also vsed at that time. And also sat there vppon the stage in the publique viewe of all the people there presente in mans apparrell \& playd vppon her lute \& sange a songe. [Appendix E to The Roaring Girl, ed. Mulholland 262]

The Roaring Girl dates from the spring of 1611, three-fourths of a year prior to January 1612, and it was performed at the Fortune Theatre, so the court record shows the probable fulfillment of Dekker's promise. It is 
possible that Mary Frith exceeded the dramatists' expectations with her own conflation of eros and theatre, re-enacting the performance of her character as almost a burlesque show and earning an official censure. In both the play and the record of her own stage performance, Moll Cutpurse plays an instrument considered immodest for a woman-a viol, played like a cello with legs spread, in the play, and the lute in the court record. In both she sings and speaks bawdily. Considering the charges that actors took audience members home as sodomitical partners, Mary Frith's offer to prove her womanhood at home must have been especially provocative. When in the court record she later denies being "dishonest of her body" (committing prostitution, but in a euphemism which itself suggests her transvestism), we could say that she even applies to her own circumstances the defense of the theatre the dramatists use her character to formulate against antitheatricalism. A life imitates the art that imitated that life.

Depending on how well the actor imitated Moll Cutpurse, the audience was probably faced with an extraordinary dislocation of signifiers when offered the opportunity to discover her sex. Mulholland suggests that while sitting on the stage, Mary Frith may have improvised asides or even taken the role herself for some part of the play ("The Date" 22). If any confusion was created between the actor and person, whether or not Mary acted herself, then could the audience trust that the "Moll" offering to prove her womanhood would be the woman she claimed to be? Inevitably, Middleton and Dekker are playing off of their audience's triple consciousness-their 
knowledge of Mary Frith as the real Moll, their acceptance of the theatrical character of Moll, and their awareness of the male actor playing the woman who wears men's clothes. Although neither Mary Frith nor the play character cross-dressed to disguise herself as a man (a point emphasized by recent critics), "Moll Cutpurse" still becomes a very slippery signifier, as is reinforced throughout the play. Sir Alexander Wengrave claims, "'Tis woman more than man,/ Man more than woman" (I. ii. 130-131), echoing the description of Ingling Pyander in Microcynicon. He also calls her "a codpiece daughter" (II. ii. 93). Moll's servant Trapdoor refers to her as "my brave captain, male and female" (III. iii. 179) and "my whorish master and mistress" (V. i. 66-67). And though Moll does not use her clothes as a disguise, Laxton still initially mistakes her for a man when they meet for his liaison (III. i. 38-55).

As a representive of eros, Moll's role in the main plot is to bring about Sebastian Wengrave's marriage with his love Mary Fitzallard. Their engagement is described as predestined; Sebastian tells Mary, "'Tis in heaven's book/ Set down that I must have thee; an oath we took/ To keep our vows" (I. i. 78-80). Such a statement of religious destiny accords with both authors' Calvinism, and having taken an oath, Sebastian and Mary are also legally bound to one another. From such a statement, the audience could be reasonably certain the marriage would happen.

However, Sebastian's father Sir Alexander Wengrave refuses his blessing on their union because of Mary's small dowry and his covetousness 
(I. i. 82), and he threatens to disinherit Sebastian if they marry. Therefore, Sebastian enlists the aid of Moll Cutpurse. Their plan is for Sebastian to feign affection for Moll and to prepare for their marriage. Their purpose is to so horrify Sir Alexander by the prospect of this union, that he would want Sebastian to marry anyone except Moll. The play also has several subplots, most of them involving Sir Alexander's friends attempting liaisons with the wives of London merchants (and Laxton with Moll), none of them successfully.

If the motivations for the main characters are ostensibly heterosexual desires, yet Middleton and Dekker repeatedly undercut the possible audience conclusion that heterosexual desire is actually presented, rather than represented, on the stage. Earlier, I noted Laura Levine's conclusion that for William Prynne and other antitheatricalists, "Heterosexual titillation is pretext and the homosexual response what is 'real.' What this spectator is 'really' attracted to when he looks at the stage is a man" (96). InThe Roaring Girl, up until the last scene (V. ii.), heterosexual desire is often represented in homoerotic terms. In Act IV, scene ii, Mistress Openwork argues against committing adultery with gallants because, "Then deal they underhand with us, and we must ingle with our husbands abed; and we must swear they are our cousins, and able to do us a pleasure at Court" (IV. ii. 62-64, emphasis added). Until this moment, the representation of the female gender of Mistress Openwork and her acquaintances the Mistresses Gallipot and Tiltyard remained unremarked; these female characters, as scripted, always 
appear in women's clothes. Now, however, if they commit adultery, they must play the male prostitutes (ingle) with their husbands. Mulholland offers other annotations for "ingle," to fondle and to cajole, but the homoerotic implication of a cross-dressed male as stage wife ingling should not be overlooked. Yet just as the authors raise the possibility of ingling, they undercut it by making it conditional: since none of the merchants' wives actually consummate a liaison with the gallants, the conditions do not arise whereby these wives must ingle with their husbands abed.

This and other representations of heterosexual activity or desire in terms of homoeroticism occur alongside allusions to and representations of ostensibly homoerotic desires and activity. The characters we would identify as homosexual (with the reservations noted earlier about ontology) are Sir Beauteous Ganymede, Sir Thomas Long, and Jack Dapper. They all appear at the edges of the plots, without significant involvement in the main story line. Yet the manner in which these characters are handled diminishes the anxiety provoked by the link of theatre and sodomy. Moreover, they are used to foreground the authors' reassertion of the pre-eminence of Christian marriage.

Sir Beauteous Ganymede and Sir Thomas Long first appear in Act V, scene $i$, as courtly associates among Moll's underworld friends. Ganymede's name comes from Latin mythology, the name of the cupbearer and page that Jupiter falls in love with and carries off to Mount Olympus. ${ }^{38}$ A homoerotic 
dramatization of their relationship opens Marlowe's Dido, Queen of Carthage. The homosexual connotation here is emphasized by Beauteous Ganymede's full name, by his association with the other characters, and, perhaps, by his association with the Court. Mulholland suggests Beauteous Ganymede alludes to Robert Carr, the handsome young Scot with whom King James had an affair (61-62). This allusion is underscored by the presence of another courtly character, Lord Noland, who has apparently been granted nobility without property (No-land). Both characters would refer to familiar complaints about the composition of King James' court.

The name of Sir Thomas Long carries with it an obvious phallic quibble, and, perhaps not coincidentally, both authors' first name. His name alone does not suggest sodomy, and although Long and Ganymede have bawdy lines, they are not sodomitical, except in their questioning, with Jack Dapper, of the disguised ex-soldiers Trapdoor and Tearcat:

Jack Dapper: Where are you maimed?

Tearcat: In both our nether limbs.

Sir Beauteous: Stay, stay, where have you served?

Sir Thomas: In any part of the Low Countries?

Trapdoor: Not in the Low Countries, if it please your manhood ... [V. i. 77-78, 82-85]

"Nether limbs," "Low Countries," and pleasing one's manhood are related to the sexual punning noted earlier in relation to Richard Easy's lands, but it should be noted that this is also a denial of sodomitical behavior-they did not serve in the "Low Countries." Homoerotic possibilities are raised, but are left unperformed. The homoerotic allusions of Ganymede's and Long's 
names were probably augmented in performance with costuming and unwritten stage business-gestures, tone of voice, and so on.

The homosexual resonance of names, by the way, extends to the main characters. In the context of the frequent sodomitical references, Alexander Wengrave could recall Alexander the Great's homosexuality, discussed earlier in relation to Hephaestion and Quomodo. Sebastian's name could recall the many paintings of St. Sebastian as a young, often effeminate, nude male pierced by arrows. Laxton's name suggests "lack-stone," the lack of both land and sexual potency, recalling the linkage of land and sex noted in Michaelmas Term. Though not ostensibly sodomites, two of these characters appear in homoerotic situations, to be examined later.

Jack Dapper is the play's most specifically identifiable sodomite; much of his characterization is drawn from Middleton's Father Hubbard's Tales and The Black Book, and the description of Gaveston in Marlowe's Edward II. In Father Hubbard's Tales, the youth advised to see the nest of boys at the Blackfriars Theatre is a farmer's son (like Richard Easy) who goes to London to waste his inheritance prodigally. Upon arriving in London, he soon dresses "his head ... up in white feathers like a shuttlecock" (68). Mulholland detects a parallel from the satire when, in II. i. 32-33, Goshawk worries that he would "appear as defective in courting [women] as a farmer's son the first day of his feather." When Jack Dapper enters the scene, he is greeted by Greenwit, "Monsieur Dapper, I dive down to your ankles" (II. i. 101); this recalls the tailor greeting the prodigal of Father 
Hubbard's Tales by measuring "all his body with a salutation," which includes the fall of the breeches (78).

Dapper goes to the Tiltyards' shop, where the main commodity is feathers. Mistress Tiltyard, hoping to identify Dapper's fashion preferences, notes the feathers favored by "the stone-riders,/ The private stage's audience, the twelvepenny-stool gentlemen" (II. i. 150-151). A "stone-rider" mounts a stallion, rather than a gelding or a mare. Because "stones" also refer to Laxton's lack of potency (I. ii. 54-58), a "stone-rider" probably refers to a sodomite. This kind of riding is what the narrator advises against in Microcynicon: "Better to go on foot than ride and fall" (Satire V, 99). Because the feathers Mistress Tiltyard is displaying are common to stoneriders and the private stage's audience (such as the audience of the Blackfriars Theatre), Jack Dapper and the farmer's son associate in the same London environs, or they are birds of a feather from the same nest. Laxton observes about Dapper, "Look you, by my faith, the fool has feathered his nest well" (II. i. 398-399; see endnote 25).

Dapper also resembles the "nest of gallants" in The Black Book who "keep at every heel a man, beside a French lacquey (a great boy with a beard) and an English page, which fills up the place of an ingle" (VII, 21). When Sir Davy Dapper describes his son's prodigality, he has followers too: "Bring him abed with these: when his purse jingles,/ Roaring boys follow at's tail, fencers, and ningles-/ Beasts Adam ne'er gave name to" (III. iii. 65-67). Furthermore, Dapper has a page, or a "hench-boy," Gull (II. i. 157). When 
they arrange to meet at Paul's, Gull observes that Dapper "could spend his three pound last night in a supper amongst girls and brave bawdy-house boys" (II. i. 128-129).

One of these "brave bawdy-house boys" may be another of Dapper's followers, about whom Sir Thomas Long inquires in Act V:

Sir Thomas: Thou hadst a sweet-faced boy, hail-fellow with thee to our little Gull: how is he spent?

Jack Dapper: Troth I whistled the poor little buzzard off o' my fist because when he waited upon me at the ordinaries, the gallants hit me $i$ ' the teeth still and said I looked like a painted alderman's tomb, and the boy at my elbow, like a death's head.

[V. i. 24-30]

It is unclear whether this sweet-faced boy is Gull himself, but he does not appear again in the play. If this is another boy, then Jack Dapper's nest includes himself, this boy, Gull, and quite possibly Sir Thomas, who has now revealed himself as familiar with Dapper's lifestyle.

In Edward II, Middleton probably found the name for Jack Dapper. In Act I of Marlowe's play, the elder and younger Mortimers are discussing Gaveston's behavior and relationship to the king. Neither Mortimer is greatly troubled by the sodomitical nature of that relationship; the elder notes, "The mightiest kings have had their minions;/ Great Alexander lov'd Hephaestion" (I. iv. 393-394). Young Mortimer, however, believes

Gaveston exceeds his social class and is overindulged:

He wears a lord's revenue on his back, And, Midas-like, he jets it in the court, With base outlandish cullions at his heels, Whose proud fantastic liveries make such show As if that Proteus, god of shapes, appear'd.

I have not seen a dapper Jack so brisk. [I. iv. 409-414] 
Here again is an extravagantly-dressed character with his male lovers at his heels, and two Roaring Girl names, Jack Dapper and Alexander, appear within twenty lines. Dapper differs from Gaveston, however, in that his partners are not exclusively male; Gull has already mentioned the girls at Dapper's supper, and Sir Davy also complains of his doting on a thousand drabs and a whore (III. iii. 61-62). Though Dapper's relationships are notably with males, his desires are not exclusively homoerotic, recalling the ontological problem of labelling him a homosexual.

A slight plot involving Jack Dapper develops in Act III, scene iii. After Sir Alexander complains again of Sebastian's pursuit of Moll, Sir Davy Dapper shows his son to be the prodigal Sir Alexander thinks Sebastian is. Sir Adam Appleton inquires, Proves your son bad too, sir?

Sir Davy: As villainy can make him, your Sebastian Dotes but on one drab, mine on a thousand! A noise of fiddlers, tobacco, wine, and a whore, A mercer that will let him take up more, Dice, and a water-spaniel with a duck. [59-64]

Sir Davy goes on to describe his son's homosexual associations, cited above (65-67). Then he tells of a plot to have him arrested on false charges of unpaid debts. He engages the assistance of the sergeant Curtalax and his yeoman Hanger to lie in wait for Jack as he exits the Greyhound Tavern.

Some of this recalls the scenes in Michaelmas Term when Shortyard and Falselight disguise as sergeant and yeoman. When Curtalax and Hanger enter, Sir Davy introduces them, "You see I'm haunted now with sprites" 
(112). In this case, neither character exhibits traits particular to his being a spirit, but the demonic associations carry through the scene. Curtalax explains their similarity to other men by noting their tendency to hypocrisy as they make arrests: "We are as other men are, sir; I cannot see but he who makes a show of honesty and religion, if his claws fasten to his liking, he draws blood" (138-140). To this Sir Davy responds, "Spoken like a noble Cerberus" (146), the three-headed dog that guards Hades. Though they would seem to be agents for morality and civil order, these officers are corrupt and the guardians of hell. Thus they function much like St. Peter traditionally does at the gate of heaven, but at the gate of the prison and with a different book:

Sir Davy: Is the action [against Jack Dapper] entered?

Hanger: His name is entered in the book of unbelievers.

Sir Davy: What book's that?

Curtalax: The book where all prisoners' names stand; and not one amongst forty when he comes in believes to come out in haste.

Sir Davy: Be as dogged to him as your office allows you to be. [146-152] "Dogged" plays on Sir Davy's earlier reference to Cerberus (146).

Although Curtalax and Hanger are not spirits, Jack Dapper faces from them essentially the same danger Richard Easy faced with his "sergeant" and "yeoman"-damnation. As Dapper and Gull leave the tavern, Moll and Trapdoor warn them of the ambush, and they escape. Retelling the incident when he is with Ganymede and Long, Dapper has somehow found out that his father was involved in the plot: "He thought, because a wicker cage tames a nightingale, a lousy prison could make an ass of me" (V. i. 41-43). 
Perhaps because Jack Dapper escapes the entrapment of his father without any later repentance, it could be said that Middleton and Dekker are leaving him neither reformed nor punished. For a play by two Calvinists, The Roaring Girl is remarkably free of retribution for Dapper. But this does not mean that Dapper is represented as exempt from the moral forces usually operative in Middleton's plays. This can be partly demonstrated by what Jack claims makes him an ass. When he and Gull are leaving the tavern, they are discussing his failures at dice:

Jack Dapper: Didst ever see such an ass as I am, boy?

Gull: No, by my troth, sir, to lose all your money, yet have false dice of your own. [III. iii. 205-207]

As in Michaelmas Term, reciprocal justice is at work; Dapper has cozened himself with his own false dice, and so is made an ass. However, Dapper's rescue by Moll's aid takes him away from the metaphorical (and possibly real) damnation of prison which could have also resulted in his being made an ass: "a lousy prison could make an ass of me" (V. i. 42-43). Dapper's rescue, therefore, also takes him away from a possible sodomitical situation which falsehood (his father's accusation of debt) would have led to, much like Quomodo's cozenage of Easy. Having escaped arrest, he has, in a sense, escaped sodomy, being made an ass, the sin to which he has been inclined. Although Dapper does not have a repentance scene, the movement of his character is away from sodomitical situations.

This movement includes as well his dismissal of the sweet-faced boy, who looked like a death's head, or the memento mori. As long as that 
relationship continued, Dapper had a constant reminder of death, the wages of $\sin$, even though the boy himself was sweet-faced. The relationship carried with it its own metaphorical condemnation, which other gallants were only too pleased to reify: "the gallants hit me i' the teeth still" (V. i. 27), when the boy waited upon him.

Jack Dapper's reformation seems to occur in a particularly Calvinistic fashion. Although there are a variety of viewpoints within Calvinism on the issue of damnation, a "book of unbelievers" suggests some kind of preregistration of those who are condemned; however, the very fact that Dapper escapes indicates that his name in the book was not his predestination. Furthermore, he does nothing to escape his condemnation; rather the means of his escape was given to him by Moll. Conceptually, Dapper's escape seems closer to a Calvinist reformation than a Catholic reformation. Dapper is still ostensibly a prodigal, but without any remaining prodigality, and Middleton and Dekker do not leave great doubts of Dapper's contented future when he escapes the book of unbelievers. 39

Of themselves, none of the homosexual characters participate in the main plot of The Roaring Girl. Instead, their significance lies first in defusing the anxieties raised by their presence, Dapper by losing the opportunities for folly, Ganymede by subordination in the concluding wedding. The play does not indicate Long's appearance in any scene other than V. i., but his unscripted appearance in V. ii. would not be improbable. 
These characters also serve significantly as the homosexual doubles and counterpoints to Sebastian, Mary, Sir Alexander, and Laxton, with Moll embodying the intersection of heterosexual and homoerotic desire. Earlier, we noted in reference to Mistress Openwork's possible ingling that heterosexual desire is often expressed in homoerotic terms. One way of noting the fluidity of those terms is to establish the parameters within which they range, from the heterosexual through indeterminate sexuality to the homosexual. Jack Dapper represents the homosexual end of the parameter. Moll has an indeterminate sexual status, notable throughout the play, including in this exchange between Laxton and Mistress Gallipot:

Laxton: She slips from one company to another like a fat eel between a Dutchman's fingers. [Aside] I'll watch my time for her.

Mistress Gallipot: Some will not stick to say she's a man, and some, both man and woman.

Laxton: That were excellent: she might first cuckold the husband and then make him do as much for the wife!

[II. i. 206-212]

Laxton's bawdy reference to eels suggests that Moll has male genitals, making her, as Mistress Gallipot notes, a hermaphrodite. Thus as a man, she cuckolds the husband, and as a woman, she cuckolds the wife. 40

Moll's indeterminate sexuality, whether she is woman, man, or hermaphrodite, provokes the other characters' interests in her sexual practices, especially whether or not she is a whore. Moll, of course, denies the charge of whoredom several times, declaring her chastity with a sword, phallic weaponry, when meeting with Laxton. Sebastian is willing to defend her chastity, but in language which has other resonances: 
Here's her worst:

Sh'has a bold spirit that mingles with mankind, But nothing else comes near it, and oftentimes Through her apparel somewhat shames her birth;

But she is loose in nothing but in mirth. [II. ii. 175-179]

Mulholland annotates lines 177 as "but nothing besides her spirit comes near mankind," and "mankind" (176) as "male sex." But even while Sebastian defends Moll's chastity, there are hints of sodomitical practices: In the contexts of Dapper's ningles and Mistress Gallipot's ingling, could the audience hear line 176 as suggesting that Moll's mingling with mankind is ingling (or ningling), especially with her "bold spirit"? This suggestion is immediately denied, of course; the point of the suggestion is to deny it even while putting it in circulation.

In the elaborate schema of doubling and counterpointing, Moll is matched with both Jack Dapper and Mary Fitzallard. In Act V, scene i, Jack Dapper addresses Moll as Jack (30); Lord Noland picks this up when he answers, "No, faith, Jack" (55) to Moll's request for tobacco. On the other hand, also in the same scene, Jack Dapper addresses her as "Sirrah Captain Mad Mary" (36). "Moll" is, of course, the diminutive form for the name "Mary," the London Moll's given name. Sebastian once addresses Mary Fitzallard as "sweet Moll" when he explains why he will seem to court Moll Cutpurse: "Thus much, sweet Moll, I must thy company shun - / I court another Moll" (I. i. 69-70). Moll explains her care for Mary, "I pitied her for name's sake, that a Moll/ Should be so crossed in love" (IV. i. 66-67). Sir Alexander observes another problem about Moll's name: 
Sebastian: Why is the name of Moll so fatal, sir?

Sir Alexander: Many one [constable], sir, where suspect is entered, Forseek all London from one end to t'other More whores of that name than any of ten other.

[II. ii. 152-155]

When with Laxton, Moll denies being a prostitute. But with elements of her gender/sexual identity taken from both Mary Fitzallard and Jack Dapper, including their names, Moll embodies sexual ambiguity. Likewise, Mary Fitzallard will resemble both Moll and Jack during her second meeting with Sebastian (IV. i).

Sebastian is also matched with and counterpointed to Dapper when Sir Davy compares his son's prodigality to Sebastian's. Both have Moll's assistance in escaping the plots of their fathers, and both are represented in homoerotic terms. Among the ostensibly heterosexual male characters, there is much interest in the sexual capabilities and states of arousal of the other men. When Mary calls on Sebastian at the Wengrave house, the servant Neatfoot tells her, "I will, fairest tree of generation, watch when our young master is erected-that is to say, up-and deliver him to this your most white hand" (I. i. 7-10). Neatfoot's promise to bring Sebastian to her also raises a question of what feeling he will give him: "Our young master shall then have a feeling of your being here presently" (26-27). Although these characters are apparently heterosexual, this category of sexuality is also modern. The dividing line is not between heterosexuals and homosexuals; the question instead is what approaches sodomy. Although Dapper is by report the sodomite, Sebastian's portrayal is at least as sodomitical. 
This is particularly evident in Sebastian's second meeting with Mary, a scene which Andor Gomme, another editor of The Roaring Girl, calls, "a dubiously suggestive piece of something near perversity" (xxiv). Mary is indispensable to the main plot, but she only appears in three scenes and each time in a costume-as a sempster in $I . i_{\text {., }}$ as a page in IV. $i .$, and in wedding dress in V. ii. Mary's every appearance is a performance; the audience never knows her as what would presumably be her undisguised self. Her appearance as a page links her to both Gull (as Dapper's page) and Ganymede (who is traditionally Jupiter's page). Thus Sebastian is further linked with Jack Dapper-his relationship to Mary as page mirroring Dapper's relationship with Gull. They meet with Moll in Sir Alexander's chamber:

Enter Sebastian with Mary Fitzallard like a page and Moll [dressed as a man].

Sebastian: Thou hast done me a kind office, without touch Either of sin or shame: our loves are honest.

Moll: I'd scorn to make such shift to bring you together else.

Sebastian: Now have I time and opportunity Without all fear to bid thee welcome, love. Kiss[es Mary].

Mary: Never with more desire and harder venture!

Moll: How strange this shows, one man to kiss another.

Sebastian: I'd kiss such men to choose, Moll; Methinks a woman's lip tastes well in a doublet. [IV. i. 39-47]

In that one kiss, everything in this play converges: the affirmation of heterosexual desire-_our loves are honest" and without sin or shame-and the simultaneous acknowledgement, display, and displacement of homoerotic desire. The homoerotic element is not very far displaced, however, because this kiss has awakened in Sebastian further desire: 
Troth, I speak seriously:

As some have a conceit their drink tastes better

In an outlandish cup than in our own,

So methinks every kiss she gives me now

In this strange form is worth a pair of two.

[IV. i. 52-56]

The language here and above also calls attention to the costuming of the actors and cross-dressing, even while none of the actors are actually dressed across gender.

Sebastian's success in love is not at all matched by Laxton, one of Sir Alexander's companions. Part of Laxton's failures at coupling can be attributed to his "lack of stones," land and potency. Sir Alexander's remarks show again the interest the males have in each other's sexual capabilities:

Sir Alexander: Furnish Master Laxton With what he wants-a stone-a stool, I would say, A stool.

Laxton: I had rather stand, sir.

Sir Alexander: I know you had, good Master Laxton.

[I. ii. 55-58]

Laxton's impotency soon suggests a lack of sexual interest in women:

Sir Alexander: Here's Master Laxton, has he mind to a woman As thou [Sebastian] hast [for Moll]?

Laxton: No, not I, sir.

Sir Alexander: Sir, I know it.

Laxton: Their good parts are so rare, their bad so common, I will have naught to do with any woman.

Sir Alexander: 'Tis well done, Master Laxton. [I. ii. 153-157]

Mulholland notes that Laxton is equivocating here: having "naught" to do with a woman can mean both having nothing to do with a woman and dealing immorally with a woman. This latter meaning is supported when "naught" is used to mean "immoral," as when Sir Alexander says Moll is naught (I. ii. 138). 
Laxton actually fancies himself a potential paramour for Moll, and he romances Mistress Gallipot for money. The point of his attraction to Moll is her sexually ambiguous nature, or her manliness, as if by mating with her, she could supply him with potency. Furthermore, returning to the analogies observed earlier, if Moll represents theatre as a cross-dressed performer, Laxton can be seen as representing the audience segment who would misuse the theatre as a sexual marketplace, especially for sodomitical liaisons. Laxton behaves like those audience members the antitheatricalists complain of who take actors for lovers. In Act II, scene $i$, a "Fellow with a long rapier" enters (243) whom Moll slugs for a previous grievance. Laxton responds, "Gallantly performed, i'faith, Moll, and manfully! I love thee forever for't. Base rogue, had he offered but the least counterbuff, by this hand, I was prepared for him" (261-263). The desire Laxton has for Moll appears to be homoerotic, based on her performing gallantly and manfully. Thus, even while romancing Moll, Laxton is behaving as if he will have nothing (naught) to do with a woman unless she behaves manfully.

Moll's response maintains the homoerotic resonances of Laxton's desire. She questions his assumption that she is unable to take care of herself (264-266); then she declares herself able to "ride":

Moll: Why do you speak this, then? Do you think I cannot ride a stonehorse unless one lead him by th'snaffle?

Laxton: Yes, and sit him bravely, I know thou canst, Moll. [268-270] The erotic possibilities - whether to ride or to be ridden-appear equally attractive to Laxton, so he immediately proposes a liaison to Moll: 
'Twas but an honest mistake through love, and I'll make amends for't any way; prithee, sweet plump Moll, when shall thou and I go out $o^{\prime}$ town together?

Moll: What to do there there?

Laxton: Nothing but be merry and lie together.

[271-273, 278-279]

He then gives her ten gold angels for the appointment.

When Laxton and Moll meet, he does not recognize her at first, mistaking her for a man. Once he recognizes her, her appearance as a man does not at all discourage his amourous intentions. However, Moll draws her sword, claiming the presumed prerogative of manliness:

Laxton: What, wilt thou untruss a point, Moll?

Moll: Yes, here's the point

That I untruss: 't has but one tag, 'twill serve though

To tie up a rogue's tongue!

[III. i. 62-64]

Recalling the advice of the narrator in Microcynicon against hiring and riding a hackney, Moll then flings Laxton's angels back at him with a challenge of ten more: "There's the gold/ With which you hired your hackney, here's her pace" (III. i. 64-65).

This is followed by Moll's defense of women generally against the reputations they get for looseness based solely on their pleasantness and mirth. This great speech has gained more comment than any other in The Roaring Girl, especially in feminist studies. These usually examine the economics of women's subjugation (contested by Moll's cross-dressing), and the power status and erotics of female cross-dressing done as a dissident strategy. 41 The perspective I offer here is not a detraction from the feminist 
studies, which have emphasized the primary import of Moll's defense.

What I wish to emphasize is that Moll's attack-on Laxton's notion that the least action is to be taken as an invitation to lustful action-can apply both to the status of women in London and to the status of cross-dressed actors in the theatre. Of course, Moll, both the character and Mary Frith, is the premier cross-dresser in either realm, London and the staged London. From Moll's lengthy defense, these sections can illustrate the point:

Laxton: Draw upon a woman? Why, what dost mean, Moll?

Moll: To teach thy base thoughts manners! Thou'rt one of those That thinks each woman thy fond flexible whore: If she but cast a liberal eye upon thee, Turn back her head, she's thine; or amongst company, By chance drink first to thee, then she's quite gone, There's no means to help her.

[III. i. 71-77]

How many of our sex by such as thou

Have their good thoughts paid with a blasted name

That never deserved loosely or did trip

In path of whoredom beyond cup and lip?

But for the stain of conscience and of soul,

Better had women fall into the hands

Of an act silent than a bragging nothing:

There's no mercy in't.

In thee I defy all men, their worst hates And their best flatteries, all their golden witchcrafts With which they entangle the poor spirits of fools.

'Cause you'll say

I'm given to sport, I'm often merry, jest;

Had mirth no kindred in the world but lust?

O shame take all her friends then! But howe'er

Thou and the baser world censure my life,

I'll send 'em word by thee[:] ...

Tell them 'twere base to yield where I have conquered.

I scorn to prostitute myself to a man,

I that can prostitute a man to me.

[103-108, 110-112] 
In this speech, Moll mentions several actions-casting a liberal eye (74), turning her head (75), drinking first to a man (76)-which a woman could do innocently but yet are taken as signs of her fallenness. We should recall that Stubbes wants his readers to mark "such wanton gestures, such bawdie speaches" as the actions that "induce whordome \& unclennes ... [the] plaine devourers of maydenly virginitie and chastitie" (L8r). What Stubbes argues against the theatre could parallel "their worst hates" (92) which Moll defies in all men; Laxton's "best flatteries" (93) are to the same point. What Stubbes condemns, Laxton wishes were so-that Moll's sport, merriness, jests, and mirth could be signs of her sexual availability, especially in the "manhood" way. Thus Moll's challenge-"Had mirth no kindred in the world but lust?" (105)—could appropriately be asked of all who suppose that performance necessarily induces lust, whether they be opponents like Stubbes or lechers like Laxton.

Moll's challenge goes further than this, however. Her defense is bracketed by discourse which shows a religious angle to the dispute over performance. First, she directs Laxton to defend himself against judgment: "Draw, or I'll serve an execution on thee/ Shall lay thee up till doomsday" (69-70; hence Laxton's question in line 71 above). Of course, the sin which Moll is judging is his presumption. After her defense, she engages him in fencing:

Moll: Would the spirits Of all my slanderers were clasped in thine, That I might vex an army at one time! They fight. 
Laxton: I do repent me; hold!

Moll: You'll die the better Christian then.

Laxton: I do confess I have wronged thee, Moll.

Moll: Confession is but poor amends for wrong, Unless a rope would follow.

Laxton: I ask thee pardon.

[III. i. 113-120]

Moll soon relents, and Laxton observes, with some irony, "Sh'has wounded me gallantly" (126; emphasis added).

Laxton's repentance and confession, making him the better Christian, suggests a stance from a Christian perspective in favor of theatre (and of women) free from the imputations of licentiousness. Moreover, Moll's defense of women who "have their good thoughts paid with a blasted name" (82) parallels Middleton's redemption of Moll's reputation from the obscene fellow in his Epistle; this parallel enhances the application of Moll's defense as a defense of theatre. 42

Laxton's repentance here does not prevent him from making further efforts against the Gallipots, though his intentions there are to get money rather than to commit adultery with Mistress Gallipot. Nevertheless, when Mistress Gallipot claims that committing adultery with a gallant would lead to ingling with her husband, the gallant she has in mind is Laxton (IV. ii. 62-64). Each time Laxton fails to achieve his goal, sodomy seems to be prevented, even though Laxton is ostensibly heterosexual.

Both Laxton and Dapper experience some pains for their transgressions, Laxton from Moll's beating and Dapper by reportedly being hit in the teeth for his sweet-faced boy. But the differences in the tone and presentation of 
these scenes suggests Laxton is the greater sinner, and the degree of their wrongdoing seems to depend upon issues of theatrical performance, rather than what would have been the common opinions of their individual actions. Laxton misuses performance for his own erotic desires.

Set against Laxton, Dapper would have been the greater sinner in common Jacobean conceptions, having consummated a sodomitical relationship. But people such as Dapper represents form some necessary portion of the theatre as either audience members ("the stone-riders, the private stage's audience" [II.i. 150-151]) or as actors. Thus Dapper learns how not to be made an ass, recalling the didactic purpose of Michaelmas Term, with Moll's aid to escape the sergeant, echoing the related aid Thomasine (the epicene) gives to Easy. Not only are Laxton and Dapper not judged according to common opinion, but common opinion itself is subjected to judgment. One part of Sir Alexander's repentance at the end of the play includes an apology to Moll:

I'll never more

Condemn by common voice, for that's the whore That deceives man's opinion, mocks his trust, Cozens his love, and makes his heart unjust.

[V. ii. 247-250]

Sir Alexander seems to enjoy the theatre if it can entertain without any claim to his moral attention. His monologue on the tapestry hanging in his gallery refers to the audience members of the Fortune Theatre (I. ii. 14-32). Among the figures therein he points out is the cutpurse who "thrusts and leers" and may be known "by a hanging villainous look" (I. ii. 26, 28). Later, 
in the streets, Moll spies a cutpurse sneaking in on her clan: "I took him once i'the twopenny gallery at the Fortune" (V. i. 283-284). These references to the Fortune serve as an indirect reminder to the audience to beware the safety of the their possessions, but they also further conflate the stage world with the larger world.

Other theatre and play references in The Roaring Girl include the Swan Theatre (V. i. 304), Dekker and Webster's play Westward Ho! (IV. ii. 137-138), Greene's Friar Bacon and Friar Bungay (IV. ii. 187) for which Middleton wrote a prologue, and the anonymous play $A$ Knack to Know an Honest Man (IV. ii. 284). In the tapestry, the theatre is contained, and thus controlled. In Moll's circle, ostensibly the larger world, people themselves move in an on-going drama, with "real" cutpurses, cross-dressers, and homosexuals. Sir Alexander likes the contained theatre, and wants to contain life in the same way.

Sir Alexander exhibits two complementary oppositions, the opposition of the comic senex which comes to resemble antitheatricalism. The first is to Sebastian's marriage of Mary Fitzallard. Mary Beth Rose observes,

The play has a traditional New Comedy plot. A young man, Sebastian Wengrave, outwits his snobbish, greedy father, Sir Alexander Wengrave, who has threatened to disinherit Sebastian if he marries the woman he loves, all because of her relatively meager dowry. [80]

Sir Alexander has the role of the senex, opposing youth, festivity, marriage, and regeneration. In the first quarto of The Roaring Girl, Sir Alexander is listed in the dramatis personae as "Went-grave," a name suggestive of his 
response to the proposed marriage. Sebastian describes a senex (and his father) as " He that is swayed/ By an unfeeling blood, past heat of love,/ His springtime must needs err" (II. ii. 104-106).

The language remarking these situations is consistently Christian. When Sebastian claims heaven's decree for his betrothal to Mary ("'Tis in heaven's book set down that I must have thee" [I. i. 78-79]), he is responding to her question of his dedication. She recalls, "A bond sealed with solemn oaths,/ Subscribed unto, as I thought, with your soul,/ Delivered as your deed in sight of heaven" (I. i. 56-58). Then she asks, "In one knot/ Have both our hands by th'hands of heaven been tied/ Now to be broke?" (I. i. 73-75). Sebastian then explains his father's opposition to the marriage: "Storms began to sit/ Upon my covetous father's brow .../ He scorned thy dowry of five thousand marks" (I. i. 81-82, 88)

Five thousand marks totaled approximately $£ 3300$ in Jacobean England, too large a dowry to account Sir Alexander's reaction as anything but selfserving. While describing Sebastian's prodigality, Sir Alexander later asserts that the "disease/ Of which all old men sicken, avarice,/ Never infected me" (I. ii. 96-98). But even Laxton has the insight to see through that disavowal: "He means not himself, I'm sure" (I. ii. 99). The spiritual issues involved in this betrothal are delineated early in the play: Sir Alexander has opposed God's decree because of his own overreaching desire for money.

Therefore, by contrast, Sebastian's plan appears to advance the godly cause. When he describes his plan to feign love for Moll Cutpurse, his 
language is reminiscent of the circuitousness of The Two Gates of Salvation. There, the "voyage" of the Christian life "lies but one way," but is guided "by the principles of Spirituall Navigation" (A2v). Sebastian reveals,

Though wildly in a labyrinth I go,

My end is to meet thee: with a side wind

Must I now sail, else I no haven can find,

But both must sink forever. [I. i. 95-98]

In the context of the language just used, "haven" is probably a pun for heaven. The route to this heavenly haven is Sebastian's side wind, Moll Cutpurse. Once Sebastian has finished explaining his plot to work with Moll, Mary answers, "My prayers with heaven guide thee!" (I. i. 114).43

Sir Alexander's opposition as a senex resembles antitheatricalism when he is confronted with Sebastian's supposed romance of Moll. To him, Moll's cross-dressing is a sign of her being a monster (a "monster with two trinkets" II. ii. 77) and a whore ("More whores of that name" II. ii. 155). Both designations would have been familiar from antitheatrical attacks on transvestism. In his opposition to Moll, Sir Alexander agrees with Laxton about her character, and like Stubbes trying to abolish theatre, he actively tries to have Moll killed. In Act IV, scene i, he sets out several valuables hoping to catch Moll stealing so that he could pursue her hanging.

Of course, Sir Alexander's opposition is to two illusions-that Moll is unchaste and that Sebastian really wants to marry her. This second illusion is the "play" within this play, and its existence at all is to complete a heavenly decree. Thus, Sir Alexander's covetousness has provoked the 
performance (Sebastian's supposed wooing of Moll) to which he is opposed; his antitheatrical perspective is an extension of his sinfulness.

Sir Alexander's fear that his son and Moll will marry reaches a crisis when he hears that they have eloped. Act V, scene ii stages his repentance, which begins with Sir Guy Fitzallard pointing out the wrong done to his daughter. His language links Sir Alexander's actions as a senex to his sinfulness:

Had I but found one spark of goodness in you

Toward my deserving child, which then grew fond

Of your son's virtues, I had eased you now;

But I perceive both fire of youth and goodness

Are raked up in the ashes of your age

Else no such shame should have come near your house. [V. ii. 33-38]

Sir Guy then offers to turn Sebastian's affections back to Mary if Sir Alexander promises to restore Sebastian's inheritance.

Although Sir Alexander's opposition to Mary Fitzalllard is ostensibly based on financial considerations, he does not advance a preferable alternative match. Earlier, we noted the homoerotic resonance of Alexander's name, and his interest in Laxton's sexual capabilities. Furthermore, in his social circle, none of his friends are ever mentioned as married. The contrast in punishment between Laxton and Jack Dapperbased not only on their sin but also on their relationship to theatre-is paralleled here by the contrast of Sir Alexander and Sebastian in relation to homoeroticism. Though St. Sebastian's representations in art are homoerotic, his saintliness is not questioned by the suggestion of possible 
male lovers; likewise, the play's Sebastian seems sodomitical, but he has a godly goal. Sir Alexander's namesake, on the other hand, was both heathen and known to be a homosexual; though Sir Alexander's behavior is not represented as if it were sodomitical, homosocial bonding takes precedence for him over marriage. Thus Sir Alexander's repentance involves reconciliing the conflicts by which marriage was forbidden and sodomitical behavior proliferated (the homoerotic expression of heterosexual love).

Sir Alexander's agreement with Sir Guy to restore Sebastian's inheritance is stated in language used in Michaelmas Term. Sir Guy first reassures Sir Alexander of his ability to change Sebastian's mind:

Sir Guy: If I change it not, Change me into a beggar!

Greenwit: Are you mad, sir?

Sir Guy: 'Tis done!

Goshawk: Will you undo yourself by doing, And show a prodigal trick in your old days?

Sir Alexander: 'Tis a match, gentlemen. [V. ii. 85-89]

Sir Guy stakes beggary on his ability to uphold his end of the deal; the pun Leinwand notes on beggary as buggery in Michaelmas Term (in close association with "undoing," line 87) may also be at work here. Because the audience already knows Sebastian's intentions, however, Sir Guy really has little at risk. 44

Goshawk's comment at first seems directed to Sir Guy, but Sir Alexander answers him and his old age has been noted throughout the play. If $\mathrm{Sir}$ Alexander undoes himself by doing, he resembles Easy, who undoes 
Quomodo's plans by re-performing the actions of his undoing when he marries Thomasine. Sir Alexander also makes a theatrical move-he "shows," or seems to do, a prodigal trick out of his age. The prodigal trick here is the risk of the inheritance, but in this case, if he has to give up the inheritance (like the prodigal son), it will be to fulfill the usual social obligations of the father to the son. Sir Alexander's "performance" of prodigality would advance the heavenly decree.

While Sir Guy is fetching Sebastian and Mary, Moll enters in her men's clothing:

Goshawk: Life, here's Moll!

Greenwit: Jack!

Goshawk: How dost thou, Jack?

Moll: How dost thou, gallant? ...

Sir Alexander: Is this your wedding gown? [V. ii. 96-98, 100]

Sir Alexander is not wholly persuaded of Sir Guy's abilities when he still believes his son will marry Moll. Here too is another link between Moll and Jack Dapper, so the question becomes whether Sebastian will marry someone like Jack. Goshawk's anwer leads to Sir Alexander's repentance:

Goshawk: Why sir, take comfort now, there's no such matter;

No priest will marry her, sir, for a woman Whiles that shape's on: an it was never known, Two men were married and conjoined in one! Your son hath made some shift to love another.

Sir Alexander: Whate'er she be, she has my blessing with her:

May they be rich and fruitful, and receive

Like comfort to their issue as I take

In them. 'Has pleased me now, marrying not this, Through a whole world he could not choose amiss.

Greenwit: Glad you're so penitent for your former sin, sir.

[V. ii. 103-113] 
Sir Alexander's former sin would include his covetousness, expressed in his refusal to permit his son's marriage to Mary; in his repentance, he affirms, "She has my blessing with her." What has changed is that Goshawk has reaffirmed the illusory nature of drama, noting Sebastian's performance, the "shift" made to love another. To Sir Alexander's earlier question of whether Sebastian would marry "a monster with two trinkets," the answer now is that it was never known to happen, neither in the world of real marriages nor in the play world. Observing again the male actor playing Moll (Moll as Jack in her last appearance), indeed no priest will marry "her" for a woman while "she" is a man.

In Middleton's Epistle, we noted his claim that "Venus, being a woman, passes through the play in doublet and breeches: a brave disguise and a safe one, if the statute untie not her codpiece point!" (14-16). The disguise is safe first because the male actor is dressed as a man, and for all the points of contention in antitheatrical arguments, they do not complain of men dressed as men. However, this man is labelled "Venus" and "Moll," and as such, the disguise is only safe if no one makes a fuss about it, which no one should because the actor is male. This is circular reasoning, but none the less effective: maintaining the illusion is preferable to seeing a naked man, unless one is an "obscene fellow." Or to seeing two men married and conjoined in one, the apex of sodomitical possiblities. To drive home that point, when the bride and groom enter and the bride is unmasked, she turns out to be Moll in a wedding dress. Sir Alexander falls into a rage. 
But this too is an illusion, and it is preferable for it to be seen as an illusion. Mary is soon brought in, and Sebastian tells his father, "Forgive me, father;/ Though there [with Moll] before your eyes my sorrow feigned,/ This [Mary] still was she for whom true love complained" (V. ii. 170-172). This marriage now confirmed, Sir Alexander speaks as if God's will has been fulfilled, and as if he has found eternal life:

Blessings eternal and the joys of angels Begin your peace here to be signed in heaven!

How short my sleep of sorrow seems now to me,

To this eternity of boundless comforts

That finds no want but utterance and expression. [V. ii. 173-177]

Sir Alexander has come to terms with the decree "to be signed in heaven," and so is disabused of his fears, and he has found his salvation, "this eternity of boundless comforts."

The conclusion of The Roaring Girl brings together four ideas which run through the play, and which, taken together, show the play as a response to theatre opponents. The first is that there may be Christian purposes in representation which antitheatricalism would squelch. The analogy in the play is the promotion of Sebastian's marriage which Sir Alexander attempts to stop.

The second idea is that the moral value of theatre depends upon seeing it as representation, rather than as presentation. Viewing the theatre as representation means accepting the female characters as women, rather than as cross-dressed men. When Sir Alexander comes to his salvation, much of the language refers to sight, using the trope of movement from darkness to 
light (discussed in chapter two). When Sebastian confesses his supposed pining for Moll, he says, "Before your eyes my sorrow feigned" (V. ii. 171). Sir Alexander rejoices, "How short my sleep of sorrow seems now to me" (V. ii. 175). His "sleep of sorrow" refers to both the spiritual death preceding salvation, and his self-delusion in failing to see Sebastian's courtship of Moll as representation, rather than presentation. So, soon after his rejoicing, Sir Alexander apologizes to Moll:

Forgive me, worthy gentlewoman, 'twas my blindness:

When I rejected thee, I saw thee not;

Sorrow and wilful rashness grew like films

Over the eyes of judgement, now so clear

I see the brightness of thy worth appear.

[V. ii. 191-195]

This comes only thirty lines after Sir Alexander has called Moll "A devil rampant!" (162) during his rage, when he thinks Moll is the bride. Now he sees the illusion she has been representing and the purpose it was to serve, his own transformation. Seeing, in this sense, is to see representation as such, not as reality. Such vision is represented as spiritually liberating.

The distinction between representation and reality has been problematized throughout the play, of course, especially when Sebastian kisses Mary the page. Now that representation is affirmed as valuable, and therefore is seen as such, we see the couple married, with no further consideration given to Mary's sex. She is refeminized, regardless of who is representing her.

The third idea stems from the second, a denial that representations necessarily signify immoral sexual activity between the actors. Goshawk's 
claim that it was never known two men were married is part of this idea. So is Moll's correction of Laxton's presumption of her looseness based on her transvestism. While Middleton offers the conflation of eros and theatre in Moll's character to the audience's venery, the only relationship brought to healthy erotic conclusion is the blessed union of Sebastian and Mary. Though the play is bawdy, its approval goes only to Christian marriage.

Moll, on the other hand, claims she will never marry:

Moll: Heard you this jest, my lord?

Lord Noland: What is it, Jack?

Moll: He was in fear his son would marry me, But never dreamt that I would ne'er agree!

Lord Noland: Why? Thou hadst a suitor once, Jack; when wilt marry? Moll: Who, I, my lord? I'll tell you when, i'faith:

When you shall hear

Gallants void from sergeants' fear

Honesty and truth unslandered,

Woman manned but never pandered,

Cheaters booted but not coached,

Vessels older ere they're broached;

If my mind be then not varied,

Next day following, I'll be married.

Lord Noland: This sounds like doomsday. [V. ii. 212-225; emphases added]

Most recent critics read Moll's refusal to marry in feminist terms, noting her marginalized status. For Jean Howard, "Marriage she rejects on political grounds as entailing an insupportable subordination and loss of independence" ("Sex and Social Conflict" 185). Jo Miller states,

In placing herself so definitely and defiantly into an androgynous role, Moll celebrates her independence from men and from women, as those roles are defined in her world. Her unwillingness to enter the market of exchange must effectively exclude her from the celebration of exchange that constitutes marriage as her society knows it. [22] 
Mary Beth Rose concludes,

Because [the authors] exclude Moll from the traditional, rejuvenated society demanded by the comic form, Middleton and Dekker never quite succeed in separating her from her outlaw status.... [H]er sexual independence has left her isolated from the very social structure that her courage and vitality have done so much to enliven and renew. [90-91]

Although each of these critics offers astute readings, none of them has mentioned that Moll is speaking here as "Jack" again. Moll, as the emblem of theatre, will not marry because theatre functions independently from, and is marginalized from, the realm in which marriage actually takes place: "No priest will marry her, sir, for a woman/ Whiles that shape's on," especially as Jack, whether "Jack's" suitor is Sebastian or Gull. Moll Cutpurse/Mary Frith lived in society's margin, which is where the theatres also functioned. The marginal status of the theatre seems to have suited Middleton and Dekker, who used the theatre for their dissident discourses.

Although with The Roaring Girl the authors deny immoral activity is actually presented (rather than represented) on stage, the problem remains of the sodomy the theatre is alleged to incite. The fourth idea is that Christian redemption extends to sodomitical persons, and therefore they can contribute to society. Theatre is not the more devilish for having sinners work in it. We have already seen in Michaelmas Term the repentance and integration into society of a prodigal sodomite. Although Jack Dapper does not repent, he has God's grace working favorably upon him. Sir Alexander also moves towards heterosexual representation; as he repents, he mentions for the first time Sebastian's mother: "I always counselled him/ To choose a 
goodly personable creature:/ Just of her pitch was my first wife, his mother" (V. ii. 130-132). We never see such counsel offered Sebastian in this play, nor do we hear of Sir Alexander remarrying, but the point is that Sir Alexander is now validating marriage, not opposing it.

Sir Beauteous Ganymede accompanies Mary when she enters to be married; his task now is not so much to illustrate the homoerotic resonance of his name as it is to fulfill his mythic function as Jupiter's cupbearer-page attending to a marriage:

[Sir Alexander:] Come, worthy friends, my honourable lord [Noland], Sir Beauteous Ganymede, and noble Fitzallard, And you, kind gentlewomen, whose sparkling presence Are glories set in marriage, beams of society, For all your loves give lustre to my joys: The happiness of this day shall be remembered At the return of every smiling spring.

Since Jove is often a theatrical representation for God, Ganymede in his mythic capacity can signify God's blessing on the marriage by his attendance. In his representation of God's blessing on marriage, Ganymede improves from his denotative representation as a sodomitical character (see endnote 38). The sodomite now serves the kingdom of God.

I started this study of Middleton's portrayal of homosexuality by observing the omission of either Christianity or homosexuality or both from the criticism. From a writer whose Christianity was early Calvinist, in the times of the Puritans, we do not expect a generous, irenic tone taken to persons who were homosexual. 45 Of course, Middleton's tone was 
motivated by his own interests in the life of the theatre. But though he treats sodomy as sin, he also disrupts the blithe citation of an unexamined Christian tradition in current political discourse. Homosexuals do not remain marginalized others in his Christian perspective.

\section{Notes}

${ }^{1}$ Unless a critic declares his or her own sexual orientation (as some do), I do not presume to guess it. My use of "gay studies" and similar terms, therefore, describes the focus of the scholarship, not the persons doing the studies. My own interest in Middleton's treatment of homosexuality stems from an interest in his religious perspectives.

2In his article, "'Masculine Love,' Renaissance Writing, and the 'New Invention' of Homosexuality," Joseph Cady makes a similar observation about the conclusions of recent gay studies. By Cady's definition, "Newinventionism" is that part of gay studies which concludes that before the late nineteenth century, a discrete homosexual subject is not commonly found. Instead, references were made to actions and those who were thought to commit them. Cady questions these conclusions by examining the use of "masculine love" in the works of Francis Bacon and Thomas Heywood, suggesting the term refers to homosexual subjectivity.

Cady labels as new-inventionism the works of Bray and Brown, Jonathan Goldberg, and Jeffrey Weeks. He worries that,

New-inventionism can also extend, if unintentionally, a helping hand to homophobia, as evidenced by an essay by Marjorie Rosenberg entitled "Inventing the Homosexual" that appeared in the December 1987 Commentary. Indicating the widespread audience newinventionism has already won, Rosenberg proclaims that "in the late 19th century ... a new kind of creature was born-'the homosexual'" and then goes on to use the vocabulary of new-inventionism to argue against social and civil rights for homosexuals, that is, since homosexuality is only an "invention" in the first place. Newinventionism can be inimical to the situation of contemporary gay people in a broader sense as well. Its implicit critique of the experiential category of homosexuality can of course work to undermine gay people's relatively recent gains in positive self-understanding, openness of expression, and social freedom.

[32] 
Obviously, from their prominence in gay studies, none of the scholars and critics Cady mentions would appreciate these results from their research. However, the preponderance of evidence seems still to favor the conclusions of "new-inventionism." Bacon's and Heywood's references to "masculine love" are too few to certify a Renaissance homosexual subjectivity, and Heywood's reference itself is disapproving. The question remains open, but is beyond the focus of this study.

3Price annotates, "What, good sweet bedfellow?" (II. iii. 136 in Levin's edition): "By their tone most of the references to Easye's and Shortyard's sleeping together imply sodomy" (105).

After I have finished this chapter, I have heard of an upcoming study, The Homoerotics of Early Modern Drama, by Mario DiGangi, which will include consideration of Michaelmas Term and No Wit, No Help Like a Woman's. DiGangi distinguishes between male homoeroticism constituent to orderly social relationships, and the indication of sodomy by the violations of social/familial/economic status. In response to my inquiry, he explains,

It is not the eroticism of the relation between Quomodo and Shortyard or Shortyard and Easy that is "sodomitical," for homoerotic desire was a recognized component of service and friendship. Rather, it is that Quomodo loses authority over his own servant and his own wife, and along with Shortyard perverts the concept of "friendship" for the purposes of seducing and fleecing a gentleman. These violations of gender and status relations mark the homoerotic desire as sodomitical.

I would not want to comment further on this thesis until I have a chance to read the full argument, which is to be published soon by Cambridge. This will be the fullest discussion of Middleton and homoeroticism when the study appears, and it sounds worthy of thoughtful consideration.

4The emphasis in this chapter will be on five texts which have characters whom we might now identify as homosexual. The other five texts are The Revenger's Tragedy; A Mad World, My Masters; No Wit, No Help Like a Woman's; The Widow; and More Dissemblers Besides Women. The homoerotic reference in The Revenger's Tragedy (I. iii. 31-40) has been noted by R. V. Holdsworth in his review article, "The Revenger's Tragedy on the Stage" (113). Theodore Leinwand comments in a note on "language which consistently hints at sodomitical rape" in Act II of A Mad World; yet, while Follywit crossdresses (IV. iii.) and is referred to as a Ganymede (II. i. 129), he does not specifically commit sodomy ("Redeeming Beggary" 69). The remaining three texts are mentioned persuasively by Susan Zimmerman as having homoerotic situations ("Disruptive Desire" 48-54). 
Most of these could be considered as teasing references: the characters involved are heterosexual, except for Lussurioso of The Revenger's Tragedy, who could be considered a bisexual, and Dondolo, a homosexual character in More Dissemblers. Dondolo's desires are defeated when the boy he wants turns out to be a woman. The Roaring Girl covers the points of interest of a similar situation, so More Dissemblers will not be examined in this chapter.

${ }^{5}$ Leinwand cites Heinemann's Puritanism and Theatre and Arthur Kirsch's Jacobean Dramatic Perspectives.

6Such an idea might have influenced an audience's response to Penitent's temptation by the succubus in A Mad World, My Masters.

7The apocryphal I Enoch regards these sons of God as angels (6: 1-2): "And it came to pass, when the sons of men had increased, that in those days there were born to them fair and beautiful daughters. And the angels, the sons of heaven, saw them and desired them" (Sparks 188).

The link between Enoch's account and the account in Genesis of antediluvian society is strengthened by citations from both texts in the epistle of Jude-Enoch in Jude 14-15, and Genesis in Jude 7 with the mention of Sodom and Gomorrah. The link between the promiscuity of angels and the presence of sodomy could be inferred from Jude 6-7: "And the angels which kept not their first estate, but left their own habitation, He hath reserved in everlasting chains under darkness unto the judgment of the great day. Even as Sodom and Gomorrha, and the cities about them in like manner, giving themselves over to fornication, and going after strange flesh, are set forth for an example, suffering the vengeance of eternal fire."

8In the epistle to his text, Nashe promises "Write who will against me, but let him look his life be without scandal; for if he touch me never so little, I'll be as good as The Black Book to him and his kindred" (31). If Nashe had written such a text, it is no longer extant.

${ }^{9}$ The passage from The Black Book restates a common complaint against the sexual relations masters had with their servants. Bray notes the scandals of Francis Bacon and the Earl of Castlehaven, who apparently had sex with their male servants (49). Other satirists, including Richard Brathwaite and John Wilmot, Earl of Rochester, also mention the practice (49). Curiously, editors of The Roaring Girl do not cite The Black Book when Jack Dapper has "Roaring boys follow at's tail, fencers, and ningles" (III. iii. 66).

10 Of course, other writers present the activities of sodomitical characters who are advised to give up their practices. Most notable as a counterpoint to Middleton's characters is Marlowe's Edward II, whom the Archbishop of Canterbury advises regarding Gaveston: 
Remember how the bishop [of Coventry] was abus'd:

Either banish him [Gaveston] that was the cause thereof,

Or I will presently discharge these lords

Of duty and allegiance due to thee. [I. iv. 59-62]

Although a religious representative is speaking, here the issue is specifically political, allegiance to Rome, rather than Edward's and Gaveston's sexual relationship, which hardly seems to matter to any of the play's religious characters. The religious perspective, as we will see, certainly matters in Middleton's plays.

${ }^{11}$ Even by Renaissance conceptions, sodomy is not the worst sin from which one of Middleton's characters experiences grace. The Husband who commits murder in A Yorkshire Tragedy has the distinction of being Middleton's worst sinner who repents.

12Leinwand notes that the persona in Microcynicon, including Satire V, will be attributed to Middleton in the Oxford edition ("Redeeming Beggary" 69).

${ }^{13}$ Line numbers for Microcynicon come from my own count of lines from Bullen's edition of the poem. Bullen himself does not include line numbers.

14Besides disclaiming responsibility for fathering Pyander, the narrator does suggest who his real father might be:

But that hereafter worlds may truly know

What hemlocks and what rue there [in the brothel] erst did grow,

As it is Sathan's usual policy,

He left an issue of like quality;

The still memorial, if I aim aright,

Is a pale chequer'd black hermaphrodite. [17-22; emphasis added]

Bray notes "a persistent motif that the child of [a union between devil and witch] is a sodomite" (21). Bray's sources extend this possibility; the human participant need not be a witch. Middleton's use of the motif here, however, should not be taken entirely seriously; its import is diminished by the duplicity of the narrator. Indeed, we may look at the narrator's suggestion as part of Middleton's ongoing questioning (or challenge) of his society's notions about sodomy and homosexuals.

We should also note the extended bawdy punning in which the brothel and the prostitute are equated: "The house wide open stands, her lodging's free:/ Admit myself for recreation/ Sometimes did enter her possession" $(6-8)$. "Possession" can stand for both the brothel and the prostitute's body. 
${ }^{15}$ In Jonson's Epigram 25, "On Sir Voluptuous Beast," Sir Beast tells his wife "the motions of each petticoat,/ And how his Ganymede moved, and how his goat" (lines 3-4).

${ }^{16} A$ Trick was also performed by the Paul's boys. Dating of Your Five Gallants is imprecise, ranging from 1604 to 1607.

${ }^{17}$ The ambiguity of "ravish" between rape and delight is also notable in Donne's Sonnet XIV, "Batter my heart, three-personed God": "I/ Except you enthral me, never shall be free,/ Nor ever chaste, except you ravish me" (lines 12-14). In his article "Pleasure and Devotion: The Body of Jesus and Seventeenth-Century Religious Lyric," Richard Rambuss reads the sonnet as expressing homoerotic desire.

${ }^{18}$ Bray cites Sir Simonds D'Ewes' autobiography, in which D'Ewes himself cites anonymous verses about Francis Bacon found at the York House in the Strand: "Within this sty a "hog doth/ lie that must be hanged/ for sodomy. *Alluding both to his surname of Bacon and to that swinish abominable sin" (Bray, "Homosexuality" 55).

${ }^{19}$ Easy's and the Wench's father's unshapenness is also evident in the prodigals of the subplot, Lethe and the Country Wench; unshapenness reaches its most demonic expression in the disguises Shortyard and Falselight assume.

Disguising and other forms of feigning are not always represented as evil actions in Middleton's plays; they lead to opportunities for Prince Phoenix to amend wrongs in The Phoenix, they protect Martia in The Widow, and they give Sebastian an opportunity to meet with his beloved Mary in The Roaring Girl. In an article discussing The Revenger's Tragedy, however, R. V. Holdsworth notes there are times when disguise is evil:

In Middleton's view one cannot develop an outward habit which proceeds to supplant one's original nature; the stable centre of self, created and donated by God, is permanently there, but cloaked in various forms of false consciousness. Planning to assume his role as Piato, Vindice claims, "I have a habit that will fit it quaintly" [I. i. 102]; indeed he has, for habit may mean "settled disposition to act in a certain way" (OED), as well as "suit of clothes." The irony of Vindice's role-playing is thus that he contrives to eradicate the doubleness of identity which for Middleton is the primary symptom of man's fallen nature. ["The Revenger's Tragedy as a Middleton Play" 101]

This doubleness of identity for Prince Phoenix, Martia, and Mary Fitzallard does not affect their opportunities for success because they are stable 
characters. Easy, Lethe, Country Wench, Shortyard, and Falselight have moved from the stable centre of self, and thus their fallen nature is on display.

${ }^{20}$ In her critique of the sentimental Catholic reader, Flannery O'Connor explains why sentimentality is a flawed concept for innocence; I think her notion of sentimentality is similar to the naiveté, gullibility, or "easiness" that Middleton implicitly critiques in Michaelmas Term:

[The reader] forgets that sentimentality [or naiveté] is an excess, a distortion of sentiment usually in the direction of an overemphasis on innocence, and that innocence, whenever it is overemphasized in the ordinary human condition, tends by some natural law to become its opposite. We lost our innocence in the Fall, and our return to it is through the Redemption which was brought about by Christ's death and by our slow participation in it. Sentimentality is a skipping of this process in its concrete reality and an early arrival at a mock state of innocence, which strongly suggests its opposite. ["The Church and the Fiction Writer" 148-149]

Middleton concludes the Induction with Michaelmas Term saying, "Sat sapienti ["a word to the wise"]; I hope there's no fools i'th' house" (Induction 73-74). The play's didactic purpose is a warning against the naiveté of young London gallants. Had Easy been able to take it, a similar offering of wisdom would presumably have spared him his trouble.

${ }^{21}$ Bray's article "Homosexuality and the Signs of Male Friendship in Elizabethan England" is the best source currently for understanding the Elizabethan distinctions between sodomy and socially acceptable activity between male friends. He cites Lyly's Euphues for an idealized version of male friendship, the relationship between Euphues and Philautus (45-46):

But after many embracings and protestations one to another they walked to dinner, where they wanted neither meat, neither music, neither any other pastime; and having banqueted, to digest their sweet confections they danced all that afternoon. They used not only one board but one bed, one book (if so be it they thought not one too many). Their friendship augmented every day, insomuch that the one could not refrain the company of the other one minute. All things went in common between them, which all men accounted commendable.

Although this is an idealized picture, it also represents a public ideal, one which is therefore "accounted commendable" by all men. In contrast, however, Lyly elsewhere calls a sodomite "a most dangerous and infectious beast" (46). 
22Anthony Bromham detects an approving allusion to Edward Coke in the character of the Cook in Middleton's late collaborative tragicomedy The Old Law ("Contemporary Significance" 335-339).

${ }^{23}$ In the introduction to his edition, Levin notes a case from the Star Chamber against a William Howe, a broker, charged with "coseninge diuers yonge gentlemen." His accomplice was a Francis East, and one of their victims was a Richard Cage. These names echo those of the primary characters of Michaelmas Term, and the play itself may fulfill the Lord Treasurer's wish to "haue those that make the playes to make a Comedie hereof, \& to acte it with these names, \& gave good Counsell to there Fathers, that when they sende there sonnes to th'innes of Cowrte to have one or too superintendentes ouer them" (xii-xiii). This case is dated June 18, 1596, approximately nine years prior to the date of Michaelmas Term, but it remains tempting to consider the case a possible source for the play.

${ }^{24}$ Two questions can be raised here. First, how were actors constumed to enable the audience to identify them as spirits and ghosts? Shortyard, with his multiple costume changes, might have been more readily identifiable as a spirit than the succubus in a $A$ Mad World, who was probably performed by the same actor who acted Mistress Harebrain. What signified the difference between a spirit and a human character?

Second, although I am reading Michaelmas Term and The Roaring Girl as, in part, responses to antitheatrical charges of sodomy, there were other charges, including denunciations of the Protean character of the stage-that role-playing and role-changing were likely to transform (for the worse, of course) the actor's personality. Middleton demonizes shapeshifting in the character of Shortyard, but what distinguishes Shortyard's transformations from those of acting itself? These are necessary questions, but are beyond the scope of this study to answer.

References to Milton here and following have been suggested to me by Bredbeck's Sodomy and Interpretation (1991).

25Two points to make here: First, Chaucer's "nest of freres" seems to be echoed by Middleton's "nest of gallants" in The Black Book who keep pages for ingles and his "nest of boys" in the Blackfriars able to ravish a man. Jack Dapper in The Roaring Girl is also said to have a nest. Although I think the evidence for a homosexual subjectivity in Jacobean London is inconclusive, in both Chaucer and Middleton, those who nest include sodomy in their activities, suggesting an earlier notion of a sodomitical community than the molly houses of the eighteenth century Bray discusses in chapter four of his study. The closest I have found to a similar use of "nest" in contemporary literature is Sidney's Arcadia when Basilius asks Pyrocles (who is disguised as an Amazon), "You praise so greatly ... your 
country that I must needs desire to know what the nest is out of which such birds do fly" (144). Pyrocles' cross-dressing is for the purpose of gaining access to romance Philoclea, Basilius' daughter, but Basilius has become infatuated with the disguised Pyrocles.

The second point: Laura Levine notes that James I's Dxmonologie "culminates in a series of 'sperm-stealing' fantasies in which spirits break into the male body and steal out its 'nature,' its very essence" (109). While, according to James, this activity was generally done when the spirit assumed the shape of a female succubus, the spirit itself was generally thought to be male. In A Mad World, Penitent claims it is a male devil that assumed Mistress Harebrain's form (IV. iv. 41-48). Thus the sexual union between humans and spirits, whether ostensibly heterosexual or homosexual, was always thought to be sodomitical.

26. Another indication of Levin's avoidance of the sexual nature of the cozenage is that, while he prefers the corrected first quarto reading "rape," he annotates it, "to rape, here, would be to seize violently." By this reading, Quomodo either would seize Thomasine to prevent her from warning Easy of his plots, or Quomodo will seize Easy's lands.

27One of the questions about Middleton's canon is whether or not he wrote The Puritan, or the Widow of Watling Street, attributed to an unknown "W. S." I believe he did, and it is possible that Quomodo's reference to "a widow about Saint Antlings" is an allusion to the play, about a Puritan widow who is vigorously courted and with a character named Nicholas St. Antlings. St. Antholin's Church was known as a Puritan stronghold. The Puritan will be included in the forthcoming Oxford edition of Middleton's works. See also chapter two, endnote 26.

A later play, More Dissemblers Besides Women, has a widow Duchess who waits seven years after the death of her first husband to remarry.

28When Shortyard dupes Sim, his "undoing" too is stated in sodomitical terms: "Tis no labor/ To undo him forever. ... For this our son and heir now, he/ From his conception was entail'd an ass" (IV. iii. 13-14, 18-19).

${ }^{29}$ What a wife's actual legal obligations would have been in a similar situation in Jacobean England would merit further research beyond the scope of this study. W. Nicholas Knight's article, "Sex and Law Language in Middleton's Michaelmas Term," usefully explicates the legal implications of much of the play's language, but without considering Thomasine's actions. Middleton, anyhow, portrays Thomasine as seeing herself as legally bound not to reveal her husband's cozenage.

30Middleton's Epistle is addressed, of course, to the reader of the text, but the Prologue spoken in the theatre, by Dekker, also offers mirth: 
A roaring girl, whose notes till now never were, Shall fill with laughter our vast theatre:

That's all which I dare promise; tragic passion, And such grave stuff, is this day out of fashion.

[Prologue 9-12]

Dekker omits Middleton's erotic emphasis here, but in the Epilogue, he promises the roaring girl "herself does woo you" (Epilogue 37).

31The current method in which the arguments opposing certain artistic or theatrical endeavours-such as the film The Last Temptation of Christ or the Robert Mapplethorpe photography exhibits-are exploited to promote those endeavours is roughly analogous to Middleton's rhetorical strategy in the "Epistle." They are all capitalizing on their vices, supposed or real. Middleton, however, is more oblique in avoiding direct mention of the antitheatricalists.

32Katherine Eisaman Maus summarizes the issue of destabilization of signs:

Tudor and Stuart polemicists against the theater, like Philip Stubbes, John Northbrooke, William Rankin, Stephen Gosson, and William Prynne, acknowledge the separability of a privileged, "true" interior [of a person] and a socially visible, falsifiable exterior even as they decry that separation, emphasizing the obligation of "all men at all times ... to seem that outwardly which they are inwardly." [4-5; Maus' citation is from Prynne's Histriomastix ].

${ }^{33}$ St. Antholin's Church (St. Antling's) is mentioned again in The Roaring Girl, in reference to a woman whose scolding is louder than the church bell (II. i. 301-302).

William Crashaw was apparently unable to pass on his convictions to his son Richard, the well-known poet who converted to Catholicism and whose attention to theatre is recorded in a couplet he wrote regarding two of John Ford's plays: "Thou cheat'st us, Ford; mak'st one seem two by art:/ What is Love's Sacrifice but The Broken Heart ?" (Hopkins 124).

34It is very likely that Middleton and Dekker are responding to Jonson's Epicoene with The Roaring Girl, carrying on the rivalry between Jonson and Dekker. They attacked each other with Poetaster and Satiromastix and their collaborative works Westward Ho! (Dekker and Webster) and Eastward Ho! (Jonson, Chapman, and Marston) maintained the competition. Jonson's disdain for Middleton has been noted earlier.

A starting point for making the comparison between The Roaring Girl and Epicoene can be the chapter on Epicoene in Laura Levine's Men in Women's Clothing (73-88). Levine examines the reproduction of 
antitheatrical arguments in Epicoene, which are then undercut by Jonson's "anti-anti-theatricality" (79). Jonson's play, with the characters Morose and Jack Daw, could have suggested to Middleton or Dekker such names as Wengrave (which their original dramatis personae of the 1611 quarto gives as "Went-grave") and Goshawk. Jonson's play is read as misogynistic by both Levine and Mary Beth Rose (50-64); The Roaring Girl contests a number of misogynistic assumptions. Therefore, a comparison of both plays in relation to antitheatricalism is a study I hope to pursue in the future.

35 Like Middleton and Dekker, Heywood is a Calvinist dramatist, notable especially in both parts of If You Know Not Me, You Know Nobody, plays based on Foxe's Acts and Monuments and about the rise of Elizabeth I.

According to Lisa Hopkins, another dramatist whose late work tends to exhibit an antitheatrical bias is John Ford. His last plays, The Fancies Chaste and Noble and The Lady's Trial, fail because of his growing distrust of language to signify: "The adoption of an aesthetic which privileges silence over speech proves ultimately self-defeating in terms of its dramaturgical capabilities" (120).

${ }^{36}$ This is not to say that the erotic issues are subordinate in the play or in social discourse to the disputes about the theatre; indeed, erotic and gender issues have been the focus of most criticism of the play. The play's pertinence to discussions of antitheatricalism has been suggested by Randall Nakayama, editor of The Life and Death of Mrs. Mary Frith:

In some sense, the play conjures up the potential dangers that antitheatrical literature claims exist in order to dispel them as baseless suspicions; the play's denoument reveals that the theatre is actually the locus of morality and that the true 'whore' is the 'common voice' ... that accuses without proof. [xxvii]

In his book on Middleton, Martin White brings up Stubbes and the anonymous Hic Mulier in reference to feminist issues:

"Conservative" opinion of the kind expressed by Stubbes and the Hic Mulier author is represented in the the play predominantly (though not exclusively) by Laxton-who assumes [Moll] is a whore who can be bought (II. i. 176-179) - and by Sir Alexander Wengrave. [57]

Both of these comments suggest the pertinence of examining The Roaring Girl in relation to antitheatrical argument, but such an examination has not previously been made.

37One problem for most studies of The Roaring Girl is determining the effect of authorial collaboration on their conclusions. Considering that 
question requires an answer to a more fundamental problem-the nature of the particular collaboration. The processes of collaboration could range from the intimate cooperation of authors to create their play, to authors (usually more than two) creating individual scenes without necessarily being aware of what all the others are writing, to authors adding to or editing another writer's text. Middleton participated in all three kinds of collaboration-his portion of Ceasar's Fall representative of the second kind, and the additions from The Witch to Macbeth typical of the third process. "Collaboration" is not an adequate term for the last process, but the effect of the text we have is produced by the work of two or more authors.

Even the collaborations in which the authors worked closely together could vary-in whether one author guided the project to its completion, in whether the authors shared the writing of scenes, in whether they revised each other's work, and in the artistic and ideological commitments of each author. Julia Gasper's study of Dekker shows him to have the same commitment to Calvinist Protestantism that I identify in Middleton's works. But Dekker tends towards romanticism where Middleton would seem to be more satiric. Dekker was also deeply influenced by Spenser, most notable in his play The Whore of Babylon, and probably in his lost collaborative play with Ford, The Fairy Knight. Patrick Cheney suggests that Moll Cutpurse shows the influence of Britomart (124-132). Spenser's artistic influence is not particularly notable in Middleton's solo works.

Mulholland finds words and phrases characteristic of both writers in most scenes of The Roaring Girl. Since Middleton wrote the epistle "To the Comic Play-reader," he probably guided the play to its publication form. However, some of the scenes in which the homosexual characters appear show more of Dekker's hand, particularly the introduction of Sir Beauteous Ganymede and Sir Thomas Long in Act V, scene i. Middleton, credited with the last scene (V. ii), uses Ganymede in the resolution, so the homosexual characters are not exclusive to either writer. Jack Dapper seems, to me, to be Middleton's creation rather than Dekker's because of his close parallels to other Middleton characters. Mulholland also credits Middleton with the scene (IV. i) of Sebastian kissing Mary while she wears men's clothes. In general, I do not think the attribution of particular scenes to either author seriously hampers readings based on the play as a whole. If I attribute a perspective on homosexuality or antitheatricalism to Middleton from The Roaring Girl, I think it quite likely that Dekker held similar opinions, much as both shared religious and political opinions.

Middleton's collaborations with Dekker seem to end with this play, perhaps because in 1612 Dekker was sent to debtors prison for seven years. Upon his release, he collaborated with William Rowley (Middleton's frequent partner), Philip Massinger, and John Ford. For studies of collaboration, Dekker's works with Ford may present more problems than his works with Middleton. According to Lisa Hopkins, Ford was probably a recusant Catholic, an unlikely partner for the militant Protestant that Gasper finds Dekker to be. 
38In Middleton's Women Beware Women, Ganymede appears in the wedding masque as a cupbearer (V. ii.), a traditional role without particular homoerotic resonance. Though without any lines, Sir Beauteous Ganymede attends Sebastian's and Mary's wedding; this will be examined later.

${ }^{39}$ There is no book of unbelievers in the Bible; the closest Biblical representation to such a book is the book of life, mentioned several times in the Revelation ( $3: 5 ; 13: 8 ; 17: 8 ; 20: 12-15 ;$ and $21: 27$ ). The usual sense of that book is that the names entered therein are the saved, and the unsaved are simply omitted, not listed in a separate book.

Middleton takes up the issue of damnation with greater depth in The Changeling; see Stachniewski.

40This line is, by the way, the closest the text ever hints at lesbianism, for how, in actuality, can Moll cuckold both sexes? But the possibility of lesbianism is never further raised, perhaps because that sexuality is not as pertinent to the disputes over the theatre. A developed possibility of lesbianism is present in another comedy in which theatre and cross-dressing are issues-Shakespeare's Twelfth Night, with Olivia's mistaken love for Viola, who is disguised as Cesario. It is Sebastian in that play that informs Olivia, "You are betrothed both to a maid and man" (V. i. 260).

41Studies of Moll's defense focusing on the economics of women's subjugation include Jo E. Miller's "Women and the Market in The Roaring Girl," Jean E. Howard's "Crossdressing, the Theatre, and Gender Struggle in Early Modern England," and Margo Hendricks' "A Painter's Eye: Gender and Middleton and Dekker's The Roaring Girl." Studies focusing on the power status and erotics of female cross-dressing include Stephen Orgel's "The Subtexts of The Roaring Girl," Howard's "Sex and Social Conflict: The Erotics of the The Roaring Girl," and chapter two of Mary Beth Rose's The Expense of Spirit: Love and Sexuality in English Renaissance Drama.

42The record of Mary Frith's offer to prove her sex at home undermines, of course, the defense the character Moll gives; Laxton and Stubbes would seem to be right after all, according to Mary. Did Middleton and/or Dekker know what she was going to do once she got on the stage? And was she aware of the implications of undermining a speech in defense of women? These are intriguing questions which we are unable to answer with any certainty, but I favor the thought that the writers' own views are represented by the speech they wrote.

43Sebastian returns to his trope of circuitousness after arguing with his father over Moll's worthiness for marriage. Once Sir Alexander leaves the scene, Sebastian remarks alone, 
I but feed

His heart to this match to draw on th'other, Wherein my joy sits with a full wish crowned-

Only his mood excepted, which must change

By opposite policies, courses indirect:

Plain dealing in this world takes no effect. [II. ii. 190-195]

44I am not suggesting that the original audience would have remembered or known enough of Michaelmas Term to have noted the similarity of language; rather I am proposing that Middleton is drawing from the same store of images.

45The perspective I am identifying as Middleton's was developed in cooperation with Dekker. Therefore, it is possible that future examinations of other Calvinistic dramatists, like Heywood, Webster, Rowley, or Dekker's solo works may yield complementary ideas about homosexuality. 
Five:

Conclusion

In his article "Forms of Opposition: Shakespeare and Middleton," Gary Taylor presents both authors as dissenters on religious grounds from the religious politics of the Court; in Shakespeare's case, from the Elizabethan as well as the Jacobean Court. Taylor characterizes Middleton's dissent as moderately Puritan and more direct than Shakespeare's, evident in The Second Maiden's Tragedy; Hengist, King of Kent; and A Game at Chess. On the other hand, the biographical information available and the literary record strongly indicate that Shakespeare was a Catholic, perhaps a recusant Catholic, but not as ideologically or religiously uncommitted as the label "Anglo-Catholic" is sometimes used to suggest. The reader may consult Taylor for his full argument, too intricate to reproduce here. ${ }^{1}$ However, I am inclined to agree with him, knowing full well that his study upsets the conventional universalization of Shakespeare.

Whether or not Shakespeare was a Catholic, we can recognize that his repentance scenes differ in emphasis from Middleton's. In The Two Gentlemen of Verona, we have this exchange between Proteus and Valentine after Valentine has caught Proteus attempting to molest Sylvia:

Proteus: My shame and guilt confounds me. Forgive me, Valentine. If hearty sorrow Be a sufficient ransom for offense, I tender 't here. I do as truly suffer As e'er I did commit.

Valentine: Then I am paid, And once again I do receive thee honest. 
Who by repentance is not satisfied

Is nor of heaven nor earth, for these are pleas'd.

By penitence th' Eternal's wrath's appeas'd;

And, that my love may appear plain and free,

All that was mine in Silvia I give thee. [V. iv. 73-83]

These lines are general enough so that they could have been written by a Protestant-but not a firm Calvinist. "Penitence" resembles "penance" when it is used to appease God's wrath. But in Calvinist and Lutheran theology, Christ appeased God's wrath with his death, and salvation is a gift of grace, by "the means [Heaven] sends to help you" (The Widow V. i. 507). In chapter two, we saw in The Revenger's Tragedy Middleton portraying repentance itself as a gift from God: "Make my tears salt enough to taste of grace!/ To weep is to our sex naturally given;/ But to weep truly, that's a gift from heaven" (IV. iv. 53-55).

Although Shakespeare rarely mentions penance directly, it remains a part of his repentance scenes, whether the religious implications are denotative or encoded in analogy. In Love's Labor's Lost, Berowne's assignment for his "reformation" (v. ii. 865) is "this twelvemonth term from day to day/Visit the speechless sick and still converse/ With groaning wretches" (846-848); thereby he appeases Rosaline to win her hand in marriage (a symbol of grace). In As You Like It, Duke Frederick, "meeting with an old religious man,/ After some question with him, was converted/ Both from his enterprise and from the world" (V. iv. 159-161). Jaques interprets the Duke's behavior as "putting on a religious life" (180), suggesting he has joined something like a monastic order. Jaques then 
decides to follow the Duke's example because "Out of these convertites/ There is much matter to be heard and learn'd" (183-184).

Once Claudio has his wrong against Hero revealed, in Much Ado About Nothing, he agrees to submit to any demands of Leonato, Hero's father: "Choose your revenge yourself;/ Impose me to what penance your invention/ Can lay upon my sin" (V. i. 266-268). Claudio's penance is to marry Leonato's supposed "niece," actually Hero in disguise, which he agrees to do even if the "niece" is an Ethiopian (iv. 37). Moreover, until Hero is revealed to be alive, Claudio also pledges to do an annual memorial rite at her tomb, which is performed in Act V, scene iii.

The transformation of Middleton's characters includes their corresponding change of behavior. Yet, the behavioral change is portrayed not as the completion of the repentance, but as its sign-Penitent and Francisco testify to Mistress Harebrain and Philippa; Helvetius refuses to aid the Tyrant further; Easy gets rid of his bad deeds; Witgood vows to forsake prodigality. But in doing all of this, none of them forsake the world, as Duke Frederick does, and none of them requests a penance, as Claudio does. Instead, they engage the life of the world, Penitent by attending a play, Francisco and Witgood by marrying, Sir Alexander by permitting a marriage, Gratiana and Helvetius by opposing the evil they formerly participated in. Only Sir Walter is banished, and not by his choice. Whereas penance is a part of several significant repentances in Shakespeare's canon, it has no part 
in Middleton's. Conversely, Shakespeare has no repentance in the Calvinist mode.

These differences should not suggest Middleton and Shakespeare would have been unable to work together; they co-authored Timon of Athens and Middleton contributed to Shakespeare's text of Macbeth and Measure for Measure (see the introductions to each play in Taylor's edition of Shakespeare and his book Shakespeare Reshaped). What the differences do suggest is the conversation, as it were, on religious subjects performed in a religious culture in dramatic genres. But that conversation can still be missed because of two strong critical tendencies. The first I have critiqued throughout this study - the tendency to regard Stubbes, Prynne, and Rainolds as representative of the majority Jacobean Protestant attitude to drama. ("Protestant" here is hardly distinguishable from "Puritan").

The second tendency is to read Shakespeare (and drama in general) as "above the fray." In Shakespearean criticism, even when the subject is religion, his religious perspectives are commonly regarded as unknowable or, indeed, as irrelevant. Donna Hamilton has recently shown that Shakespeare critiques the terminology of polemical Protestant ecclesiology in such plays as King John, Twelfth Night, Measure for Measure, Cymbeline, and Henry VIII. This suggests a stance from which he opposes a large section of Protestantism. But Hamilton resists making such a claim:

Shakespeare's personal religious beliefs (about the eucharist or about predestination, for example) are not at issue in this book, any more than is the matter of whether or not the plays can be thematised in 
theological terms. I offer no speculation on whether or not Shakespeare was a Calvinist, Arminian, catholic, separatist, or atheist; I assume we do not need to know that to proceed with this other project. (Such identities are difficult to work out in the best of circumstancessuch as that of a systematic thinker presenting his views in the genre of treatise or sermon-and much more difficult when the genre is drama.)

[xiii]

I do not wish to minimize the difficulty of establishing identities, but Hamilton's study achieves more than she claims for it. It is no great leap from her work to conclude Shakespeare was not an atheist, nor a separatist, nor a Calvinist.

For drama criticism in general, we need to take seriously Debora Shuger's assertion-"that the English Renaissance was a religious culture, not simply a culture whose members generally were religious" (6). This means we should assume that any particular Tudor or Stuart dramatist has a religious perspective until we can demonstrate that he or she does not. Studies such as Hopkins has done on John Ford, Gasper on Thomas Dekker, Hamilton on Shakespeare, and I have done on Middleton need to be expanded to Webster, Jonson, Greene, Heywood, Massinger, and Elizabeth Cary. This type of criticism will problematize the criticism of those who wish to purify the stage from the taint of religion ${ }^{2}$ (whether Stubbes or Rowe). But it will also increase our understanding of the dramatists' usual religious habits of thought-their commitments, differences, points of negotiation, and points on which they would not compromise.

For Middleton criticism specifically, when the Oxford complete works is finally published, we will find that many of his texts have barely been 
considered: plays such as The Nice Valour, Wit at Several Weapons, and The Bloody Banquet; prose texts such as Plato's Cap, The Peacemaker, and The Penniless Parliament of Threadbare Poets; and the civic pageants. Other texts will appear in a new light when placed chronologically; a natural sequel to this study would be an examination of Middleton's pre-1613 tragedies. If sources can be identified for his known missing texts, perhaps a study of their ideology would suggest the appeal they held for a Calvinist dramatist. Finally, whatever direction Middleton scholarship takes in the future, a critic should presume that the text is by a Calvinist.

I. Notes

1Borrowing the title of Taylor's book, a critic of his argument could say that he is "reinventing Shakespeare." A close look at his edition of Shakespeare's complete works will show that Taylor has long been about that task. The reader will not find Henry VIII but All Is True, and the name of the miles gloriosus (Falstaff) in Henry IV, Part I becomes (or is returned to) Sir John Oldcastle.

${ }^{2} \mathrm{My}$ phrase is intended to echo Dickens on page 25 above. 


\section{Works Cited}

Altieri, Joanne. "Against Moralizing Jacobean Comedy: Middleton's Chaste Maid." Criticism: A Quarterly for Literature and the Arts 30 (1988): 171-187.

Augustine. City of God. Trans. Henry Bettenson. Introd. John O'Meara. Harmondsworth: Penguin, 1984.

Ayers, P. K. "Plot, Subplot, and Dramatic Discord in AMad World. My Masters and A Trick to Catch the Old One." Modern Language Quarterly 47 (1986): 3-18.

Baines, Barbara Joan. The Lust Motif in the Plays of Thomas Middleton. Salzburg: Universitat Salzburg, 1973.

Barish, Jonas. The Anti-Theatrical Prejudice. Berkeley: University of California Press, 1981.

Barker, Richard H. Thomas Middleton. New York: Columbia UP, 1958. Westport, CT: Greenwood Press, 1974.

Beck, Ervin. "Terence Improved: The Paradigm of the Prodigal Son in English Renaissance Comedy." Renaissance Drama 6 (1973): 107-122.

Bergeron, David M. "Middleton's Moral Landscape: A Chaste Maid in Cheapside and The Triumphs of Truth." Friedenreich 133-146.

Biggs, Murray. The Questionable Ending of Middleton's A Trick to Catch the Old One: How Seriously Can We Take the Palinodes?" Notes and Queries 41 (1994): 507-509.

Bray, Alan. Homosexuality in Renaissance England. London: Gay Men's Press, 1982.

--. "Homosexuality and the Signs of Male Friendship in Elizabethan England." Queering the Renaissance. Ed. Jonathan Goldberg. Durham: Duke UP, 1994. 40-61.

Bredbeck, Gregory W. Sodomy and Interpretation: Marlowe to Milton. Ithaca: Cornell UP, 1991.

Bromham, Anthony A. "The Contemporary Significance of The Old Law." Studies in English Literature 1500-1900 24 (1984): 327-339. 
Brown, Judith. Immodest Acts: The Life of a Lesbian Nun in Renaissance Italy. Oxford: Oxford UP, 1986.

Bryant, J. A. "Middleton as a Modern Instance." Sewanee Review 84 (1976): 572-594.

Booty, John E., ed. The Book of Common Prayer 1559: The Elizabethan Prayer Book. Charlottesville: University Press of Virginia, 1976.

Bouwsma, William J. Iohn Calvin: A Sixteenth-Century Portrait. Oxford: Oxford UP, 1988.

Bullen, A. H., ed. The Works of Thomas Middleton. 8 vols. Boston: Houghton, Mifflin, 1885.

Bunyan, John. The Pilgrim's Progress. Ed. G. B. Harrison. New York: Dutton, 1978.

Cady, Joseph. "'Masculine Love,' Renaissance Writing, and the 'New Invention' of Homosexuality." Homosexuality in Renaissance and Enlightenment England. Ed. Claude J. Summers. New York: The Haworth Press, 1992.

Cawley, A. C. and Barry Gaines, eds. A Yorkshire Tragedy. Manchester: Manchester UP, 1986.

Calvin, John. Calvin's Commentaries: The First Epistle of Paul the Apostle to the Corinthians. trans. John W. Fraser. Edinburgh: Oliver and Boyd, 1960.

-. Institutes of the Christian Religion. 2 volumes. trans. Henry Beveridge. Grand Rapids, Michigan: Eerdmans Publishing, 1981. Used for citations.

-. Institutes of the Christian Religion. Ed. John T. McNeill. Trans. Ford Lewis Battles. Philadelphia: Westminster Press, 1960.

Chaucer, Geoffrey. The Riverside Chaucer. Third Edition. Ed. Larry D. Benson. Boston: Houghton Mifflin Company, 1987.

Cheney, Patrick. "Moll Cutpurse as Hermaphrodite in Dekker and Middleton's The Roaring Girl." Renaissance and Reformation 7 (1983): 120-134.

Cherry, Caroline Lockett. The Most Unvaluedst Purchase: Women in the Plays of Thomas Middleton. Salzburg: Universitat Salzburg, 1973. 
Cook, Ann Jennalie. "'Bargaines of Incontinencie': Bawdy Behavior in the Playhouses." Shakespeare Studies 10 (1977): 271-290.

Corbin, Peter and and Douglas Sedge, eds. Three Jacobean Witchcraft Plays. Manchester: Manchester UP, 1986.

Covatta, Anthony. Thomas Middleton's City Comedies. Cranbury, New Jersey: Associated University Presses, 1973.

Crashaw, William. A Sermon at Paul's Cross. London, 1608. STC \# 6027.

Crewe, Jonathan. "The Theater of the Idols: Theatrical and Anti-theatrical Discourse." Staging the Renaissance: Reinterpretations of Elizabethan and Jacobean Drama. Eds. David S. Kastan and Peter Stallybrass. New York: Routledge, 1991. 49-56.

Dekker, Thomas. The Plague Pamphlets of Thomas Dekker. Ed. F. P. Wilson. London: Oxford UP, 1925.

DiGangi, Mario. Letter to the Author. 23 November, 1996.

Donne, John. The Complete English Poems. Ed. A. J. Smith. Harmondsworth: Penguin, 1971.

Dynes, William R. "The Trickster-Figure in Jacobean City Comedy." Studies in English Literature 1500-1900 33 (1993): 365-385.

Erasmus, Desiderius. The Praise of Folly. Trans. John Wilson. Roslyn, NY: Walter J. Black, 1942.

Farley-Hills, David. The Comic in Renaissance Comedy. London: Macmillan, 1981.

Farmer, David Hugh. The Oxford Dictionary of Saints. Third Edition. Oxford: Oxford UP, 1992.

Foxe, John. The Acts and Monuments of John Foxe: $A$ New and Complete Edition. Ed. Stephen Reed Cattley. Vol. 6. London: R. B. Seeley and W. Burnside, 1841.

-. Two Latin Comedies. Trans. John Hazel Smith. Ithaca: Cornell UP, 1973.

Friedenreich, Kenneth, ed. "Accompaninge the players": Essays Celebrating Thomas Middleton, 1580-1980. New York: AMS Press, 1983. 
Friedenreich, Kenneth. "Introduction: How to Read Middleton." Friedenreich 1-14.

Gasper, Julia. The Dragon and the Dove: The Plays of Thomas Dekker. Oxford: Oxford UP, 1990.

-. "The Reformation plays on the public stage." Theatre and Government under the Early Stuarts. Eds. J. R. Mulryne and Margaret Shewring. Cambridge: Cambridge UP, 1993.

The Geneva Bible: A Facsimile of the 1560 Edition. Intro. Lloyd E. Berry. Madison: University of Wisconsin Press, 1969.

Goldberg, Jonathan. Sodometries: Renaissance Texts, Modern Sexualities. Stanford: Stanford UP, 1992.

Guilpin, Everard (Edward). Skialetheia. Ed. D. Allen Carroll. Chapel Hill: University of North Carolina Press, 1974.

Hallett, Charles A. Middleton's Cynics: a Study of Middleton's Insight into the Moral Psychology of the Mediocre Mind. Salzburg: Universitat Salzburg, 1975.

Hamilton, Donna B. Shakespeare and the Politics of Protestant England. Lexington: University Press of Kentucky, 1992.

Haselkorn, Anne M. Prostitution in Elizabethan and Jacobean Comedy. Troy, New York: Whitston Publishing Company, 1983.

Heinemann, Margot. Puritanism and Theatre: Thomas Middleton and Qpposition Drama under the Early Stuarts. Cambridge: Cambridge UP, 1980.

Hemminge, William. William Hemminge's elegy on Randolph's finger, containing the well-known lines "On the time-poets". Ed. G. C. Moore Smith. Oxford: Basil Blackwell, 1923.

Hendricks, Margo. "A Painter's Eye: Gender and Middleton and Dekker's The Roaring Girl." Women's Studies 18 (1990): 191-203.

Holdsworth, R. V., ed. Three Jacobean Revenge Tragedies: A Casebook. London: Macmillan, 1990.

-. "The Revenger's Tragedy as a Middleton Play." Holdsworth 79-105. 
Holdsworth, R. V. "The Revenger's Tragedy on the Stage." Holdsworth 105-120.

Holmes, David. The Art of Thomas Middleton: A Critical Study. Oxford: Oxford UP, 1970.

Hopkins, Lisa. Iohn Ford's Political Theatre. Manchester: Manchester UP, 1994.

Hotz-Davies, Ingrid. "A Chaste Maid in Cheapside and Women Beware Women: Feminism, Anti-Feminism and the Limitations of Satire. Cahiers Elisabethains 39 (1991): 29-39.

Howard, Jean E. "Crossdressing, the Theatre, and Gender Struggle in Early Modern England." Shakespeare Ouarterly 39 (1988): 418-440.

- "Sex and social conflict: the erotics of The Roaring Girl." Zimmerman 170-190.

Huebert, Ronald. "Middleton's Nameless Art." Sewanee Review 95 (1987): 591-609.

Jonson, Ben. Bartholomew Fair. Ed. G. B. Hibbard. London: Ernest Benn Ltd.; New York: W. W. Norton, 1977.

-. The Complete Poems. Ed. George Parfitt. Harmondsworth: Penguin, 1975. Includes "Conversations with William Drummond."

- The Devil is an Ass. Four Jacobean City Comedies. Ed. Gamini Salgado. Harmondsworth: Penguin, 1985.

Kamps, Ivo. "Ruling Fantasies and the Fantasies of Rule: The Phoenix and Measure for Measure." Studies in Philology 92 (1995): 248-273.

Kirsch, Arthur. Jacobean Dramatic Perspectives. Charlottesville: University Press of Virginia, 1972.

Knight, W. Nicholas. "Sex and Law Language in Middleton's Michaelmas Term." Friedenreich 89-108.

Lake, David J. The Canon of Thomas Middleton's Plays: Internal Evidence for the Major Problems of Authorship. Cambridge: Cambridge UP, 1975.

Lancashire, Anne, ed. The Second Maiden's Tragedy. Manchester: Manchester UP, 1978. 
Leinwand, Theodore B. The City Staged: Jacobean Comedy 1603-1613. Madison: University of Wisconsin Press, 1986.

-. "Redeeming Beggary/Buggery in Michaelmas Term." English Literary History 61 (1994): 53-70.

Levin, Richard. The Multiple Plot in English Renaissance Drama. Chicago: University of Chicago Press, 1971.

Levine, Laura. Men in Women's Clothing: Anti-theatricality and Effeminization 1579-1642. Cambridge: Cambridge UP, 1994.

Lindsay, Sir David. The Monarche and Other Poems. London: Early English Text Society, 1883.

Lodge, Thomas and Robert Greene. A Looking Glass for London and England. Drama of the English Renaissance: The Tudor Period. Eds. Russell Fraser and Norman Rabkin. New York: Macmillan, 1976. 383-409.

Loughrey, Bryan and Neil Taylor, eds. Thomas Middleton: Five Plays. Harmondsworth: Penguin, 1988.

Machiavelli, Niccolo. The Mandragola. Five Italian Renaissance Comedies. Ed. Bruce Penman. Harmondsworth: Penguin, 1978.

Marlowe, Christopher. The Complete Plays. Ed. J. B. Steane. Harmondsworth: Penguin, 1969.

Marotti, Arthur. "Fertility and Comic Form in A Chaste Maid in Cheapside." Comparative Drama 3 (1969): 65-74.

-. "The Method in the Madness of A Mad World My Masters." Tennessee Studies in Literature 15 (1970): 99-108.

Massinger, Philip. The Roman Actor. Drama of the English Renaissance: The Stuart Period. Eds. Russell Fraser and Norman Rabkin. New York: Macmillan, 1976. 715-742.

Maus, Katharine Eisaman. Inwardness and Theater in the English Renaissance. Chicago: University of Chicago Press, 1995.

Messina, Joseph. "The Moral Design of A Trick to Catch the Old One." Friedenreich 109-132. 
Middleton, Thomas. The Black Book. Bullen, volume VIII: 1-45.

- A Chaste Maid in Cheapside. Loughrey and Taylor, 161-238. Used for citations.

-. A Chaste Maid in Cheapside. Ed. Alan Brissenden. New York: W. W. Norton, 1968.

- Father Hubbard's Tales; or. The Ant and the Nightingale. Bullen, volume VIII: 47-109.

-. A Game at Chess. Ed. J. W. Harper. New York: W. W. Norton, 1966.

-. God's Parliament-House. London: J. Okes, 1627. STC\# 17904.7.

- Hengist, King of Kent. Ed. R. C. Bald. New York: Charles Scribner's Sons, 1938.

-. A Mad World, My Masters. Ed. Standish Henning. Lincoln: University of Nebraska Press, 1965. Used for citations.

- A Mad World, My Masters and Other Plays. Ed. Michael Taylor. Oxford: Oxford UP, 1995.

- The Marriage of the Old and New Testament. London: Nicholas Okes, 1620. STC \# 17904.5.

-. Michaelmas Term. Ed. Richard Levin. Lincoln: University of Nebraska Press, 1966. Used for citations.

-. Michaelmas Term and A Trick to Catch the Old One. Ed. George R. Price. The Hague: Mouton, 1976.

-. Microcynicon. Bullen, vol. VIII: 111-136.

-. No Wit, No Help Like a Woman's. Ed. Lowell E. Johnson. Lincoln: University of Nebraska Press, 1976.

-. The Revenger's Tragedy. See Tourneur. For Middleton's authorship, see Loughrey and Taylor, xxv-xxviii.

-. The Second Maiden's Tragedy. See Lancashire.

-. A Trick to Catch the Old One. Ed. G. J. Watson. New York: W. W. Norton, 1968. 
Middleton, Thomas. The Triumphs of Truth. Bullen, volume VII: 229-266.

-. The Two Gates of Salvation. London: Nicholas Okes, 1609. STC \# 17904.3.

-. A Critical Edition of Thomas Middleton's "The Widow". Ed. Robert Trager Levine. Austria: Universitat Salzburg, 1975.

-. The Witch. Corbin and Sedge 85-142.

- Women Beware Women. Ed. Roma Gill. New York: W. W. Norton, 1968.

-. A Yorkshire Tragedy. See Cawley and Gaines.

Middleton, Thomas and Thomas Dekker. The Roaring Girl. Ed. Paul Mulholland. Manchester: Manchester UP, 1987.

- The Roaring_Girl. Ed. Andor Gomme. New York: W. W. Norton, 1976.

Middleton, Thomas and William Rowley. The Changeling. Ed. N. W. Bawcutt. Manchester: Manchester UP, 1958.

-- A Fair Ouarrel. Ed. R. V. Holdsworth. New York: W. W. Norton, 1974.

Miller, Jo E. "Women and the Market in The Roaring Girl." Renaissance and Reformation 26 (1990): 11-23.

Milton, John. Complete Poems and Major Prose. Ed. Merritt Y. Hughes. Indianapolis: Bobbs-Merrill Educational Publishing, 1957; 1983.

Mount, David B. "The '[Un]reclaymed forme' of Middleton's A Trick to Catch the Old One." Studies in English Literature 1500-1900 31 (1991): 259-272.

Mulholland, Paul. "The Date of The Roaring Girl." Review of English Studies 28 (1977): 18-31.

-.. "The Two Gates of Salvation: Typology, and Thomas Middleton's Bibles." English Language Notes 23.2 (1985): 27-36.

--. Letter to the author. 7 February 1994.

Nakayama, Randall S., ed. The Life and Death of Mrs. Mary Frith. New York: Garland Publishing, 1993. 
Nashe, Thomas. Pierce Penniless his Supplication to the Devil. The Unfortunate Traveller and Other Works. Ed. J. B. Steane. Harmondsworth: Penguin, 1971.

O'Connor, Flannery. "The Church and the Fiction Writer." Mystery and Manners. New York: Farrar, Straus \& Giroux, 1961. 143-153.

-. "Some Aspects of the Grotesque in Southern Fiction." Mystery and Manners. New York: Farrar, Straus \& Giroux, 1961. 36-50.

- Wise Blood. 1949. Three by Flannery O'Connor. New York: New American Library, 1962. 7-126.

Orgel, Stephen. "Nobody's Perfect: Or Why Did the English Stage Take Boys for Women?" South Atlantic Ouarterly 88 (1989): 7-29.

-.. "The subtexts of The Roaring Girl." Zimmerman 12-26.

Parker, R. B. "Middleton's Experiments with Comedy and Judgement." Iacobean Theatre. Eds. J. R. Brown and Bernard Harris. New York: Edward Arnold, 1960. 178-199.

-. Introduction. A Chaste Maid in Cheapside. By Thomas Middleton. Manchester: Manchester UP, 1969.

Parker, Thomas H. L. Iohn Calvin: A Biography. Philadelphia: Westminster Press, 1975.

Parsons, Robert. The first booke of the christian exercise, appertayning to resolution. Rouen, 1582. STC \# 19353.

- A Booke of Christian exercise, appertaining to Resolution ... by R.P. Perused, and accompanied now with aTreatise tending to pacification: by E. Bunny. London: N. Newton, 1584. STC \# 19355. The Protestant adaptation.

Paster, Gail Kern. "The City in Plautus and Middleton." Renaissance Drama 6 (1973): 29-44.

-. "Quomodo, Sir Giles, and Triangular Desire: Social Aspiration in Middleton and Massinger." Comedy from Shakespeare to Sheridan. Ed. A. R. Braunmuller and J. C. Bulman. Newark: University of Delaware Press, 1986.

Pendleton, Thomas A. "Shakespeare's disguised duke play: Middleton, Marston, and the sources of Measure for Measure." "Fanned and 
Winnowed Opinions": Shakespearean Essays Presented to Harold Ienkins. Eds. John W. Mahon and Thomas A. Pendleton. London: Methuen, 1987. 79-98.

Rainolds, John. Th'overthrow of Stage-Playes. Middleburgh, 1599. New York: Johnson Reprint Company, 1972.

Rambuss, Richard. "Pleasure and Devotion: The Body of Jesus and Seventeenth-Century Religious Lyric." Queering the Renaissance. Ed. Jonathan Goldberg. Durham: Duke UP, 1994.

Ribner, Irving. Lacobean Tragedy: The Ouest for Moral Order. London: Methuen, 1962.

Richman, David. "Directing Middleton's Comedy." Friedenreich 79-88.

Root, Robert L. "The Troublesome Reformation of Penitent Brothel: Middletonian Irony and A Mad World My Masters." College Language Association Journal 25 (1981): 82-90.

Rose, Mary Beth. The Expense of Spirit: Love and Sexuality in English Renaissance Drama. Ithaca: Cornell UP, 1988.

Rowe, George E. Thomas Middleton and the New Comedy Tradition. Lincoln: University of Nebraska Press, 1979.

Rowley, William, Thomas Dekker and John Ford. The Witch of Edmonton. Corbin and Sedge 143-209.

S., W. The Puritan or, The Widow of Watling-Street. London: Tudor Facsimile Texts, 1911; reprinted New York: AMS Press, 1970.

Saccio, Peter. Letter to the author. 18 August 1996.

Sampson, Martin W., ed. Thomas Middleton: Masterpieces of the English Drama. New York: American Book Company, 1915.

Shakespeare, William. The Complete Works of William Shakespeare. Ed. David Bevington. 3rd ed. Glenview, IL: Scott, Foresman, 1980. Used for citations.

- William Shakespeare: The Complete Works. Eds. Stanley Wells and Gary Taylor. Oxford: Oxford UP, 1988.

Shand, G. B. "The Elizabethan Aim of The Wisdom of Solomon Paraphrased." Friedenreich 67-77. 
Shapiro, Michael. Children of the Revels: The Boy Companies of

Shakespeare's Time and Their Plays. New York: Columbia UP, 1977.

Shuger, Debora K. Habits of Thought in the English Renaissance. Berkeley: University of California Press, 1990.

Sidney, Sir Philip. The Countess of Pembroke's Arcadia. Ed. Maurice Evans. Harmondsworth: Penguin, 1977.

Slights, William W. E. "The Trickster-Hero and Middleton's A Mad World, My Masters." Comparative Drama 3 (1969): 87-98.

Smith, Bruce R. Homosexual Desire in Shakespeare's England. Chicago: University of Chicago Press, 1991.

Sparks, H. F. D., ed. The Apocryphal Old Testament. Oxford: Oxford UP, 1984.

Spenser, Edmund. The Faerie Queene. Ed. Thomas P. Roche. Harmondsworth: Penguin, 1978.

Stachniewski, John. "Calvinist Psychology in Middleton's Tragedies." Holdsworth 226-247.

Steen, Sara Jayne. Ambrosia in an Earthen Vessel: Three Centuries of Audience and Reader Response to the Works of Thomas Middleton. New York: AMS Press, 1991.

Stubbes, Philip. The Anatomie of Abuses. London, 1583. New York: Johnson Reprint Company, 1972.

Takase, Fumiko. "Thomas Middleton's Antifeminist Sentiment in A Mad World. My Masters." Playing with Gender: A Renaissance Pursuit. Ed. Jean R. Brink. Urbana: U' of Illinois Press, 1991.

Taylor, Gary. "Forms of Opposition: Shakespeare and Middleton." English Literary Renaissance 24 (1994): 283-314.

-. Reinventing Shakespeare: A Cultural History from the Restoration to the Present. Oxford: Oxford UP, 1989.

Taylor, Gary and John Jowett. Shakespeare Reshaped 1606-1623. Oxford: Oxford UP, 1993. 
Tourneur, Cyril [Thomas Middleton]. The Revenger's Tragedy. Ed. R. A. Foakes. Manchester: Manchester UP, 1966. rpt. 1990.

Webster, John. The White Devil. Three Plays. Ed. David C. Gunby. Harmondsworth: Penguin, 1972. 33-166.

White, Martin. Middleton and Toumeur. New York: St. Martin's Press, 1992.

White, Paul Whitfield. Theatre and Reformation: Protestantism, Patronage and Playing in Tudor England. Cambridge: Cambridge UP, 1993.

Wigler, Stephen. "Penitent Brothel Reconsidered: The Place of the Grotesque in Middleton's A Mad World. My Masters." Literature and Psychology 25 (1975): 17-26.

-. "Thomas Middleton's A Chaste Maid in Cheapside: The Delicious and the Disgusting." American Image 33 (1976): 197-215.

Williams, Robert I. "Machiavelli's Mandragola, Touchwood Senior, and the Comedy of Middleton's A Chaste Maid in Cheapside." Studies in English Literature 1500-1900 10 (1970): 385-396.

Yachnin, Paul. "Social Competition in Middleton's Michaelmas Term." Explorations in Renaissance Culture 13 (1987): 87-99.

Zimmerman, Susan, ed. Erotic Politics: Desire on the Renaissance Stage. New York: Routledge, 1992.

Zimmerman, Susan. "Disruptive Desire: Artifice and Indeterminacy in Jacobean Comedy." Zimmerman 39-63. 


\section{$\underline{\text { Vita }}$}

Herbert Jack Heller was born September 21, 1962 in Baton Rouge, Louisiana. He was raised in Kenner, Louisiana, where he attended A. C. Alexander Elementary School, Theodore Roosevelt Middle School, and Alfred Bonnabel High School. He graduated from Bonnabel High in 1980. From there he attended Moody Bible Institute in Chicago until 1983. He then transferred to Bryan College in Dayton, Tennessee; he graduated in 1985 with a B. A. in English.

Heller then spent two years teaching English at the Gezhouba Institute of Hydroelectric Engineering in Yichang, People's Republic of China. This job gave him many opportunities to travel in China and Hong Kong, and to learn of another nation's culture and history. He would like to visit China again some day.

In 1987, Heller returned to the United States to begin graduate work in English at Louisiana State University. He earned his M. A. in 1989. In 1997, he completed his doctorate. In the years intervening, Heller has worked at a clothing warehouse, a car rental company, and a high school as a substitute teacher. 


\section{DOCTORAL EXAYINATION AND DISSERTATION REPORT}

Candidate: Herbert Jack Heller

Major Flelds English

Iitle of Dienestation: Penltent Brothellers: Grace, Sexuality and Genre in Thomas Middleton's City Comedies

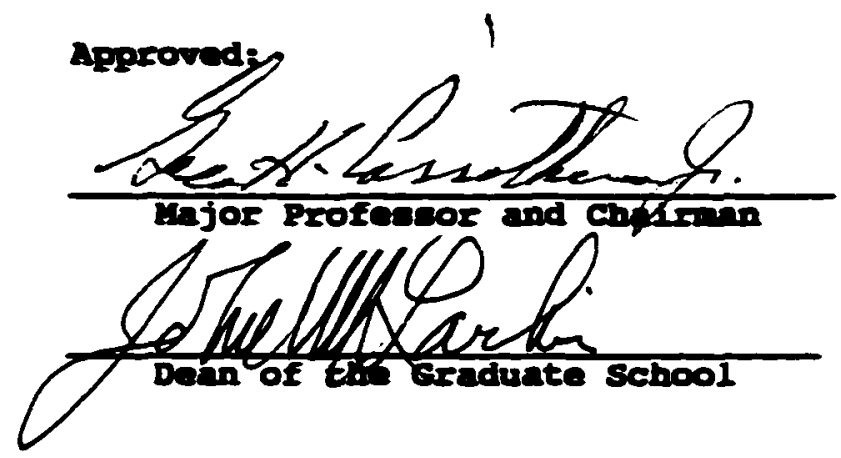

EXAYINING COMAITIEE:

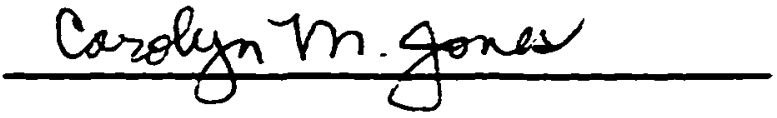

Gura K. Nando

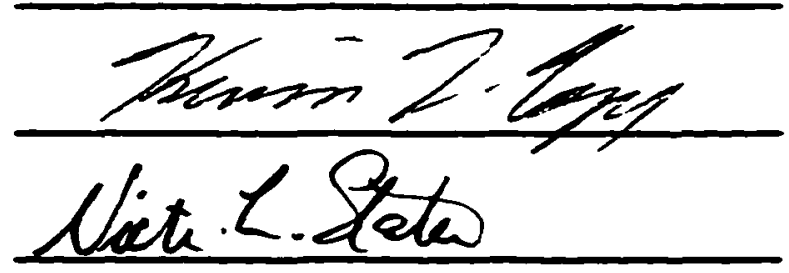

Date of Bramination:

135 rine 99 